\title{
SINGLE-FAMILY HEATING AND COOLING REQUIREMENTS: ASSUMPTIONS, METHODS, AND SUMMARY RESULTS
}

\section{TOPICAL REPORT}

\author{
Prepared by \\ R.L. Ritschard, J.W. Hanford, and A.O. Sezgen \\ Lawrence Berkeley Laboratory \\ Applied Science Division \\ Berkeley, CA 94720
}

For

Gas Research Institute

GRI Contract No. 5086-800-1318

GRI Project Manager

James M. Fay

Strategic Planning \& Analysis

Through U.S. Department of Energy

under Contract No. DE-AC03-76SF00098

This document is PUBLICLY RELEASABLE BStaclo Authorizing Official Date: $5 \cdot 23-0 \mathrm{C}$

March 1992

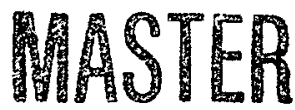




\section{DISCLAIMER}

This report was prepared as an account of work sponsored by an agency of the United States Government. Neither the United States Government nor any agency Thereof, nor any of their employees, makes any warranty, express or implied, or assumes any legal liability or responsibility for the accuracy, completeness, or usefulness of any information, apparatus, product, or process disclosed, or represents that its use would not infringe privately owned rights. Reference herein to any specific commercial product, process, or service by trade name, trademark, manufacturer, or otherwise does not necessarily constitute or imply its endorsement, recommendation, or favoring by the United States Government or any agency thereof. The views and opinions of authors expressed herein do not necessarily state or reflect those of the United States Government or any agency thereof. 


\section{DISCLAIMER}

Portions of this document may be illegible in electronic image products. Images are produced from the best available original document. 


\section{GRI DISCLAIMER}

LEGAL NOTICE: This report was prepared by Lawrence Berkeley Laboratory as an account of work sponsored by Gas Research Institute (GRI). Neither GRI, members of GRI, nor any persons acting on behalf of either:

1. Makes any warranty of representation, expressed or implied, with respect to the accuracy, completeness, or usefulness of the information contained in this report, or that the use of any apparatus, method, or process disclosed in this report may not infringe on privately owned rights; or

2. Assumes any liability with respect to the use of, or for damages resulting from the use of, any information, apparatus, method, or process disclosed in this report.

This report is available from National Technical Information Service, U. S. Department of Commerce, 5285 Port Royal Road, Springfield, VA 22161. 


\section{RESEARCH SUMMARY}

TITLE

CONTRACTOR

PRINCIPAL

INVESTIGATOR

REPORT

OBJECTIVE

TECHNICAL PERSPECTIVE
Single Family Heating and Cooling Requirements:

Assumptions, Methods, and Summary Results

Lawrence Berkeley Laboratory

Applied Science Division

1 Cyclotron Road

Berkeley, California 94720

\section{R.L. Ritschard}

May 1990 - March 1992

To update previous GRI single-family data base using the latest version of DOE-2, more representative weather tapes, improved modeling techniques, and more recent data on typical building construction practices in the U.S.

A building loads data base for single-family detached buildings will help GRI and its contractors to assess new gas technologies and target R\&D efforts. This data base of building energy requirements augments the existing GRI loads data for the multifamily and office buildings sectors. The data base includes loads for various building end-uses such as space heating and cooling, water heating, and non-HVAC electricity.

The research has created a data base of hourly building loads using a state-ofthe-art building simulation code (DOE-2.1D) for 8 prototypes, representing pre1940 s to 1990 s building practices, in 16 U.S. climates. The report describes the assumed modeling inputs and building operations, defines the building prototypes and selection of base cities, compares the simulation results to both surveyed and measured data sources, and discusses the results. The full data base with hourly space conditioning, water heating, and non-HVAC electricity consumption is available from GRI. In addition, the estimated loads on a per square foot basis are included as well as the peak heating and cooling loads. 
TECHNICAL

APPROACH

PROJECT

IMPLICATIONS
Modeling assumptions and building characteristics were developed for 8 building types representing pre-1940s, 1950-1970,1980s, and 1990s construction practices. The 1980 s prototypes were based on a statistical analysis of the 1987 RECS data. The thermal characteristics for the 1990s construction were developed to conform to the proposed ASHRAE 90.2 revision and the 1987 National Appliance Energy Conservation Act and its 1988 Amendments. These prototypes and assumed operating conditions were simulated using the DOE-2 model with WYEC and TMY hourly weather tapes. Engineering calculations were used to calculate water heating loads and non-HVAC electricity use. The results as annual loads data were binned in several formats and presented in the Appendices.

The development of a consistent set of building energy requirements for prototypical single-family detached buildings will provide end-use data that can be used by GRI and its contractors to plan and analyze R\&D programs. These single-family loads will provide the basis for future analyses of issues related to the use of advanced gas technologies.

\section{Project Manager}

Mr. James M. Fay

Strategic Planning \& Analysis 


\section{Table of Contents}

1. INTRODUCTION ....................................................................................................

2. TECHNICAL APPROACH …….........................................................................

PREVIOUS WORK ..............................................................................................

OUTLINE OF APPROACH .......................................................................................

SELECTION OF WEATHER TAPES AND BASE CITIES .......................................... 4

Selection of Base Cities ........................................................................................... 4

Description of Weather Tapes .................................................................................. 5

Basis of Choice ........................................................................................................ 7

3. MODELING ASSUMPTIONS ……............................................................................. 8

STRUCTURAL ASSUMPTIONS …………......................................................

Building Prototypes ............................................................................................... 8

General Building Characteristics ......................................................................... 9

Window Areas ..................................................................................................... 13

Building Thermal Integrity ............................................................................ 13

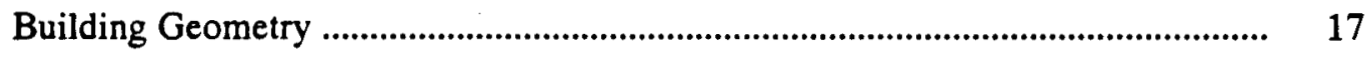

Infiltration .......................................................................................... 17

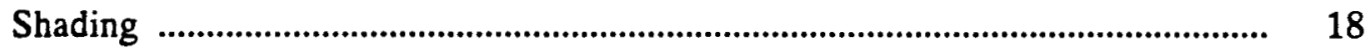

Foundations .............................................................................................. 18

OPERATING ASSUMPTIONS .......................................................................... 19

Thermostat Settings ................................................................................................. 19

Internal Loads ............................................................................................ 19

Non-HVAC Loads Methodology ......................................................................... 23

Domestic Hot Water Loads Methodology ............................................................... 23

4. RESULTS ............................................................................................................... 26

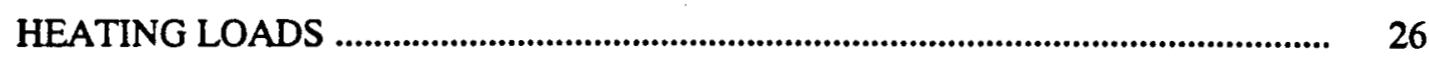

Space Heating ...................................................................................................... 26

Annual Loads ............................................................................................... 26

Annual Peak Heating Loads ............................................................................. 31

Heating Load Intensities ......................................................................................... 35

Water Heating Loads ............................................................................................... 35 
COOLING LOADS .......................................................................................... 42

Space Cooling ...................................................................................................... 42

Total Annual Loads ........................................................................................... 42

Annual Latent Cooling Loads .............................................................................. 45

Peak Cooling Loads ................................................................................................ 45

Cooling Load Intensities ........................................................................................... 47

NON-HVAC LOADS .................................................................................................. 47

TOTAL ANNUAL SPACE CONDITIONING LOADS ............................................... 50

COMPARISON TO MEASURED AND SURVEYED DATA .................................... $\quad 50$

RECS Survey Data .............................................................................................. 51

BECA Measured Data ............................................................................................. 53

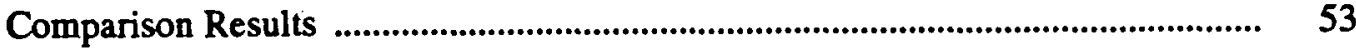

5. REFERENCES …................................................................................................ 59

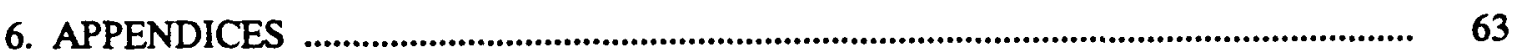

INPUT DEVELOPMENT AND SENSITIVITIES

Appendix A: Sample Representation of Prototypes ................................................ A-1

Appendix B: Building Size Analysis of 1980s/1990s House .................................. B-1

Appendix C: Sample DOE-2 Input File ................................................................ C-1

Appendix D: B1+Prototype Cooling Load Sensitivity Study ……………………... D-1

Appendix E: Peak Cooling Load Sensitivity Analysis ........................................... E-1

Appendix F: Latent Load Sensitivity Analysis ................................................. F-1

BINNED RESULTS

Appendix G: Monthly Water Heating Loads ....................................................... G-1

Appendix H: Binned Building Loads ............................................................... H-1

Appendix I: Binned Climate Data ...................................................................... I-1 


\section{LIST OF TABLES}

Table No.

Title

Page No.

1 Base Cities for Single-Family Data Base 6

2 General Specifications for A and B Prototypes 9

3 General Specifications for C and D Prototypes 12

4 General Specifications for B1+ and D+ Prototypes 14

5 Conservation Parameters for A and B Prototypes 15

6 Conservation Parameters for C and D Prototypes 16

$7 \quad 1987$ RECS Data Tape Results-Appliance Saturations and Types by Census Division $\quad 21$

8 Annual Appliance and Lighting Energy Use 23

9 Estimated Annual Internal Loads per Building 24

10 Average Air and Well Temperatures and Hot Water Use for Base Cities 25

11 Total Building Loads for Single-Family Prototypes 28-30

12 Peak Building Loads for Single-Family Prototypes 32-34

13 Total and Peak Building Load Intensities for Single-Family Prototypes

14 Aggregated Building Loads for Single-

Family Data Base Comparison

15 RECS Analysis Summary-Building Loads

by Census Division and Prototype

16 BECA-B Results Summary-Building Loads by Census Division and Prototype 


\section{LIST OF FIGURES}

Figure No.

Title

Page No.

\begin{tabular}{|c|c|c|}
\hline 1 & Average Floor Area for New Construction & 11 \\
\hline 2 & Construction Type for New Construction & 11 \\
\hline 3 & Internal Loads Profile, Occupant Loads, and Lighting Loads & 22 \\
\hline 4 & Annual Heating Loads for Single Family Prototypes & 27 \\
\hline 5 & $\begin{array}{l}\text { Heating Loads on Typical Winter Day for Four } \\
\text { Prototype Buildings in Chicago }\end{array}$ & 36 \\
\hline 6 & $\begin{array}{l}\text { Heating Loads/Sq.Ft.-Four Prototype } \\
\text { Single-Family Buildings in Chicago }\end{array}$ & 40 \\
\hline 7 & Heating Loads/Sq.Ft.-A1 Prototype Buildings in Four Cities & 41 \\
\hline 8 & $\begin{array}{l}\text { Domestic Hot Water Loads in Single- } \\
\text { Family Buildings for Four Cities }\end{array}$ & 43 \\
\hline 9 & Annual Cooling Loads for Single-Family Prototypes & 44 \\
\hline 10 & $\begin{array}{l}\text { Cooling Loads on Typical Summer Day } \\
\text { for Four Prototype Buildings in Chicago }\end{array}$ & 46 \\
\hline 11 & $\begin{array}{l}\text { Latent Cooling Loads on Typical Summer } \\
\text { Day for Two Prototype Buildings in Chicago }\end{array}$ & 46 \\
\hline 12 & $\begin{array}{l}\text { Total Cooling Loads/Sq.Ft.-Four Prototype } \\
\text { Single-Family Buildings in Chicago }\end{array}$ & 48 \\
\hline 13. & $\begin{array}{l}\text { Total Cooling Loads/Sq.Ft.-A1 Prototype } \\
\text { Buildings in Four Cities }\end{array}$ & 48 \\
\hline 14. & $\begin{array}{l}\text { Latent Cooling Loads/Sq.Ft.-Four Prototype } \\
\text { Single-Family Buildings in Chicago }\end{array}$ & 49 \\
\hline 15. & $\begin{array}{l}\text { Latent Cooling Loads/Sq.Ft.-A1 Prototype } \\
\text { Buildings in Four Cities }\end{array}$ & 49 \\
\hline 16. & $\begin{array}{l}\text { Fuel Space and Water Heat Prototype A, } \\
\text { A1 Comparison with RECS Data }\end{array}$ & 55 \\
\hline 17. & $\begin{array}{l}\text { Fuel Space and Water Heat Prototype B, } \\
\text { B1 Comparison with RECS Data }\end{array}$ & 55 \\
\hline 18. & $\begin{array}{l}\text { Fuel Space and Water Heat Prototype C } \\
\text { Comparison with RECS Data }\end{array}$ & 56 \\
\hline 19. & $\begin{array}{l}\text { Electric Space Cooling Various } \\
\text { Prototypes Comparison with RECS }\end{array}$ & 56 \\
\hline 20 & $\begin{array}{l}\text { Space and Water Heat Various } \\
\text { Prototypes Comparison with BECA }\end{array}$ & 58 \\
\hline 21 & $\begin{array}{l}\text { Space Heat Only Various Prototypes } \\
\text { Comparison with BECA }\end{array}$ & 58 \\
\hline
\end{tabular}

-vii- 


\section{1 \\ INTRODUCTION}

The Gas Research Institute (GRI) has sponsored research over the past several years to develop building energy requirements for prototypical buildings in three economic sectors: single-family, multifamily, and offices. These heating and cooling requirements have been estimated using a state-of-the-ant building energy simulation code (DOE-2.1) and other engineering calculations. Several reports are available that document these studies. Applied Management Sciences, Inc. (AMS) completed a regional characterization of residential buildings and developed heating and cooling requirements for single-family detached houses using DOE-2.1B. ${ }^{1}$ AMS also characterized typical multifamily building types for the U.S. Battelle Pacific Northwest Laboratories, using clustering techniques, analyzed and categorized the office building sector and completed a DOE-2 analysis of these prototypical buildings. ${ }^{3}$ The Lawrence Berkeley Laboratory (LBL) has also made contributions to GRI's set of building energy studies. LBL recently completed an analysis of the multifamily heating and cooling requirements. ${ }^{4}$ These simulated loads were compared to measured data from several areas in the country. 5

The purpose of this study was to update the previous single-family data base using the latest version of DOE-2, more representative weather tapes, and improved modeling techniques (e.g., infiltration and ventilation). LBL has conducted previous studies of single-family residences as part of the U.S. Department of Energy's program to develop energy guidelines for new construction. ${ }^{6}$ Also, the single-family data base, developed to support the DOE guidelines, was used to support recent revisions to the ASHRAE 90.2 standard $^{7}$ and DOE's Mandatory Standards for New Federal Residences. ${ }^{8}$ In addition to improving GRI's single-family data base, this study covers prototypes for the 1980 s that were developed from a statistical analysis of the latest RECS public data tape ${ }^{9}$ and the most recent national building characteristics surveys conducted by the National Association of Home Builders (NAHB). ${ }^{10}$ Prototypical buildings were also developed to represent 1990 s construction practices. The thermal characteristics of the 1990s construction are assumed to conform to the proposed ASHRAE 90.2 Standard, which will be the code requirement in the 1990s. ${ }^{11}$ The appliance efficiencies in these buildings also conform to the 1987 National Appliance Energy Conservation Act and 1988 Amendments. ${ }^{12}$ The effects of these appliance efficiencies on space contitioning loads were also analyzed in a separate study sponsored by GRI. ${ }^{13}$

In this report, the technical approach used to generate the heating and cooling loads, water heating loads, and aggregate electric usage (i.e., lighting and appliances) is described. This description covers the building prototypes for each vintage (pre-1940s, 1950-70s, 1980s, and 1990s), selection of base cities, and the operating conditions assumed in the simulations. The contents of the single-family data base are summarized, and a brief discussion of these 
results is presented. In the discussion chapter, a comparison is made of the simulation results to measured data for some cities. Several appendices are also included that contain a sample DOE-2 input file, results for a series of large buildings (1950-70s and 1990s), and sample results binned in different formats. The full data base, covering hourly heating, sensible and latent cooling load capacity, water heating loads, and non-HVAC electricity usage, is available as another output of this study. This data base, which is available from GRI will provide the buildings research community with a standard set of prototypical loads by building type and location for all major U.S. climates. 


\section{TECHNICAL APPROACH}

\section{PREVIOUS WORK}

GRI initiated the development of building energy requirements for standard buildings with an analysis of single-family detached housing. ${ }^{1}$ In that study, six prototypes representing different years of construction and levels of thermal integrity were selected for each of 18 cities. Using the DOE-2.1B building energy simulation code, loads were calculated for each prototype and binned by outdoor temperatures.

To complete the characterization of the residential sector, GRI then supported a survey of all publicly and privately available data on multifamily building characteristics and the development of building prototypes. ${ }^{2}$ This work identified 16 prototypical multifamily buildings representative of various vintages (pre-1940s to 1980s) and building characteristics (i.e., levels of insulation, etc.) for each of the four U.S. Census Regions. This characterization was completed by LBL with the development of a multifamily loads data base similar to that for single-family detached housing, using the DOE-2.1D building energy simulation program and related calculational procedures. ${ }^{4}$ GRI has also completed a characterization and data base for the office building sector. ${ }^{3}$

Independent of the above-mentioned GRI studies, LBL has developed a methodology for defining DOE-2 inputs and simulating heating and cooling loads in residential buildings. 6,7 These GRI and LBL studies form the technical basis for this effort to update and improve the data base of prototypical single-family building loads.

\section{OUTLINE OF APPROACH}

This project updates the previous single-family data base using DOE-2.1D, updated weather tapes, and improved modeling techniques. In addition, new building prototypes were developed to characterize energy requirements in large single-family buildings. The technical approach used to develop the data for the single-family buildings followed these steps:

1. We reviewed the methodology, building prototype descriptions, modeling assumptions, and results of the previous work to assess the accuracy and identify inconsistencies with the current program requirements. We collected more recent data to update and expand the building descriptions and modeling assumptions.

2. We compiled a complete set of input parameters including building construction characteristics (i.e., insulation and glazing levels, building orientation, number of stories, etc.) and typical operating conditions (e.g., thermostat settings, number of occupants, and 
intemal heat gains) for 8 prototypical single-family buildings in each of the 16 base cities. These parameters are described in detail in this report.

3. We next created DOE-2 input files using these input parameters and selected the appropriate hourly weather data for 16 cities representing the major climate types and population centers of the US. We provide in Appendix A a sample DOE-2 input file for one prototype building in Chicago. For the weather data, we used WYEC (Weather Year for Energy Calculations) weather tapes for 13 of the 16 locations. For three locations (Chicago, New Orleans, and San Francisco) we used TMY weather data. We describe in this report the process used to select the most appropriate weather tape and base city locations.

4. We developed pre- and post-processor programs to allow easy manipulation of the input and output data. For consistency, all building inputs are based on a single master DOE-2 input file. Two binning routines were designed to process the hourly output data into monthly summaries and to bin them by temperature, humidity ratio, and time of day. These post-processing programs were used to produce the sample data tables shown later in the report.

5. We performed the DOE-2 simulations and processed the building space conditioning loads through the binning methods to arrange the results into the various formats presented in the data tables (see Results section and the Appendices).

6. Separate procedures were used to calculate the domestic water heating loads (monthly as well as the hourly profile for each day) and aggregate electricity usage. These calculated values are presented in tabular format and also aggregated with the results from the DOE-2 simulations to derive the total annual loads for each prototype building.

\section{SELECTION OF WEATHER TAPES AND BASE CITIES}

\section{Selection of Base Cities}

We established three important criteria for determining which cities to use in the singlefamily building simulations. First, since the prototype buildings are regional characterizations of the building stock, the basic regional division of the US found in the RECS data and GRI regional models should be represented, which includes the Northeast, North Central, South, and West regions. Second, all significant climate types within each region should be represented. Significance should be determined by population and uniqueness of the climate. Third, the choice of cities should be as consistent as possible with the previous AMS singlefamily study and the LBL multifamily work just completed, and should include about 15 locations.

We relied on earlier work at $\mathrm{LBL}$ and GLOM, a computer-based interactive climate agglomeration program, for the analysis. ${ }^{14}$ GLOM is a tool for aggregating Standard 
Metropolitan Statistical Areas (SMSAs) into climate groups based on climate characteristics and populations. Similarities in heating degree days, cooling degree days, $\mathrm{Kt}$ - which measures solar potential, and latent enthalpy hours most similar, climate center. The Andersson paper provides several examples of climate groupings depending on the desired number of climate groups and the relative importance of climate and population.

GLOM allowed us to construct groupings of cities based on both climate and geographic distributions or census regions. The best result was a grouping of 16 climate zones with two in the Northeast region (one in each the New England and Mid Atlantic census divisions), three in the North Central region (one in the East and two in the West North Central divisions), five in the South region (three in the South Atlantic and two in the West South Central divisions), and six in the West region (three in each the Mountain and Pacific divisions). The population centers of these climate groups were chosen as the base cities for the characterizations and simulations. It should be noted that while each of the four census regions includes between two and six base cities, not all of the nine census divisions include a base city. For example, climates in the East South Central census division are represented by the climates of Forth Worth, Washington DC, and Atlanta, yet none of these base cities are actually in the division. The base cities are shown in Table 1.

\section{Description of Weather Tapes}

Detailed building energy simulation programs, such as DOE-2, require hourly weather information for temperature, humidity, wind speed, and the amount of sunshine. This information can be derived from weather tapes that have a minimum of three-hour recordings for dry bulb and wet bulb temperatures, direct and diffuse solar radiation, wind speed and direction, and atmospheric pressure.

Depending on the objective of the building simulation, one can choose between TRY (Test Reference Year), TMY (Typical Meteorological Year), WYEC (Weather Year for Energy Calculations), or actual year weather tapes. For benchmark studies such as the multifamily data base, weather data representing long-term mean conditions for any location are preferred. The first three mentioned weather tape types (TRY, TMY and WYEC) are different attempts to produce a year of "typical" weather.

TRY weather tapes were prepared by the National Climatic Data Center and are actual years chosen from 27 years of records as the most representative for a particular location. The selection was done by searching through the historical data and progressively eliminating those

¥ A measure of the latent heat removal necessary to meet comfort conditions. Enthalpy hours (Btu hour/pound air) are calculated by summing over the year the energy necessary to lower ambient air conditions to a humidity ratio of 0.116 and a dry-bulb temperature of $75^{\circ} \mathrm{F}$. 
years with the most atypical monthly conditions. TRY tapes do not have solar data, only cloud cover observations that the DOE-2 program uses to estimate the amount of sunshine.

Table 1. Base Cities for Single-Family Data Base.

\begin{tabular}{|c|c|c|c|c|c|c|c|}
\hline $\begin{array}{l}\text { Census Region/ } \\
\text { Division }\end{array}$ & $\begin{array}{l}\text { Base } \\
\text { Cities }\end{array}$ & $\begin{array}{l}\text { Weather } \\
\text { Tape }\end{array}$ & $\begin{array}{r}\text { Hea } \\
\text { Degrea } \\
\left(60^{\circ} \mathrm{F}\right)\end{array}$ & $\begin{array}{l}\text { ing } \\
\text { Days } \\
\left(65^{\circ} \mathrm{F}\right)\end{array}$ & $\begin{array}{l}\text { Cooling } \\
\text { Degree Days } \\
\left(65^{\circ} \mathrm{F}\right)\end{array}$ & $\begin{array}{c}\text { Cool. Degree } \\
\text { Hours } / 24 \\
\left(75^{\circ} \mathrm{F}\right)\end{array}$ & $\begin{array}{c}\text { Latent } \\
\text { Enthalpy Days } \\
\left(75^{\circ} \mathrm{F}, 0.0116 \mathrm{HR}\right)\end{array}$ \\
\hline $\begin{array}{l}\text { NORTHEAST } \\
\text { New England }\end{array}$ & Boston & WYEC & 4396 & 5627 & 699 & 186 & 48 \\
\hline Mid Allantic & New York & WYEC & 3784 & 4882 & 1005 & 256 & 118 \\
\hline $\begin{array}{l}\text { NORTH CENTRAL } \\
\text { East North } \\
\text { Central }\end{array}$ & Chicago & TMY & 4946 & 6120 & 969 & 318 & 121 \\
\hline $\begin{array}{l}\text { West North } \\
\text { Central }\end{array}$ & $\begin{array}{l}\text { Minneapolis } \\
\text { Kansas City }\end{array}$ & $\begin{array}{l}\text { WYEC } \\
\text { WYEC }\end{array}$ & $\begin{array}{l}6733 \\
3799\end{array}$ & $\begin{array}{l}8004 \\
4799\end{array}$ & $\begin{array}{r}727 \\
1605\end{array}$ & $\begin{array}{l}238 \\
632\end{array}$ & $\begin{array}{r}72 \\
269\end{array}$ \\
\hline $\begin{array}{l}\text { SOUTH } \\
\text { South Allantic }\end{array}$ & $\begin{array}{l}\text { Washington } \\
\text { Allanta } \\
\text { Miami }\end{array}$ & $\begin{array}{l}\text { WYEC } \\
\text { WYEC } \\
\text { WYEC }\end{array}$ & $\begin{array}{r}3184 \\
2050 \\
91\end{array}$ & $\begin{array}{r}4180 \\
2965 \\
222\end{array}$ & $\begin{array}{l}1388 \\
1543 \\
3922\end{array}$ & $\begin{array}{r}403 \\
405 \\
1193\end{array}$ & $\begin{array}{r}244 \\
284 \\
1155\end{array}$ \\
\hline $\begin{array}{l}\text { West South } \\
\text { Central }\end{array}$ & $\begin{array}{l}\text { Fort Worth } \\
\text { New Orleans }\end{array}$ & $\begin{array}{l}\text { WYEC } \\
\text { TMY }\end{array}$ & $\begin{array}{r}1571 \\
804\end{array}$ & $\begin{array}{l}2329 \\
1374 \\
\end{array}$ & $\begin{array}{l}2495 \\
2503 \\
\end{array}$ & $\begin{array}{r}1044 \\
789 \\
\end{array}$ & $\begin{array}{l}490 \\
719 \\
\end{array}$ \\
\hline $\begin{array}{l}\text { WEST } \\
\text { Mountain }\end{array}$ & $\begin{array}{l}\text { Denver } \\
\text { Albuquerque } \\
\text { Phoenix }\end{array}$ & $\begin{array}{l}\text { WYEC } \\
\text { WYEC } \\
\text { WYEC }\end{array}$ & $\begin{array}{r}4621 \\
3147 \\
675 \\
\end{array}$ & $\begin{array}{l}5879 \\
4186 \\
1320\end{array}$ & $\begin{array}{r}611 \\
1256 \\
3609 \\
\end{array}$ & $\begin{array}{r}329 \\
540 \\
2144 \\
\end{array}$ & $\begin{array}{r}0 \\
9 \\
97\end{array}$ \\
\hline Pacific & $\begin{array}{l}\text { Seatule } \\
\text { San Francisco } \\
\text { Los Angeles }\end{array}$ & $\begin{array}{l}\text { WYEC } \\
\text { TMY } \\
\text { WYEC }\end{array}$ & $\begin{array}{r}3583 \\
1682 \\
635\end{array}$ & $\begin{array}{l}5136 \\
3172 \\
1636\end{array}$ & $\begin{array}{r}90 \\
66 \\
428\end{array}$ & $\begin{array}{l}39 \\
28 \\
54\end{array}$ & $\begin{array}{l}0 \\
0 \\
6\end{array}$ \\
\hline
\end{tabular}

TMY weather tapes were prepared under contract to the U.S. Department of Energy for use in solar design studies. The TMY data are composite years created by merging 12 representative months chosen from climate data for years 1954 through 1972. Solar radiation values were based on SOLMET observations for 26 stations, and extrapolated for other locations. The selection process for the typical months involved comparing monthly data to the long-term cumulative distribution for nine weather indices, such as temperatures and wind speeds, and selecting the month with the closest correlation. Since no single month has the closest correlation for all indices, different weighting were applied to each index.

WYEC weather tapes were prepared under contract to the American Society of Heating, Refrigeration, and Air-conditioning Engineers (ASHRAE) for use in building energy calculations. ${ }^{15}$ They are similar to the TMY tapes in being composite years consisting of 12 typical months, but used a different weighting method and adjusted the solar radiation to secure close 
compliance to the long-term mean conditions. In addition, more time was spent to smooth discontinuities and abnormalities in the data. As of 1989, WYEC weather tapes were available for 44 U.S. locations which give good coverage for major population centers, but with only one location in California (Los Angeles).

\section{Basis of Choice}

There are numerous drawbacks to the use of TRY weather tapes. It is unlikely that any year would have "typical" weather each month. Moreover, the selected TRY year may not represent the long-term mean in any of the important weather indices. Finally, unlike TMY and WYEC, the TRY tapes do not include measured solar radiation but rather inferred values in the form of cloud cover. Because of these limitations, ASHRAE no longer recommends using TRY weather tapes for building energy simulations.

The choice between TMY and WYEC weather tapes is somewhat less obvious, since their selection processes are similar. We chose WYEC tapes because they were produced with more care than TMY tapes. In addition, the WYEC tapes are now considered more acceptable to the technical community. The expected difference in weather-sensitive loads for TMY cities (vs using WYEC) should be negligible. For this study, we used WYEC tapes for all cities except for Chicago, New Orleans, and San Francisco. We observed anomalies in the Chicago WYEC weather tape, and WYEC was not available for New Orleans or San Francisco. Weather tapes for each base city are given in Table 1.

We understand that ASHRAE is currently modifying the WYEC weather tapes to adjust for anomalies in local time, etc. The modified WYEC tapes were not available at the time of this project. The WYEC weather tapes used for this analysis were the original tapes with similar modifications performed by the Building Simulation group at LBL. 


\section{3}

\section{MODELING ASSUMPTIONS}

\section{STRUCTURAL ASSUMPTIONS}

\section{Building Prototypes}

The A, A1, B, B 1, C, and D single-family building prototypes for each region or base city were selected and characterized in a previous GRI study. ${ }^{1}$ The A and Al prototypes represent as-built and thermally improved buildings (i.e., retrofit) of pre-1940 vintage, respectively. Similarly, the B and B1 prototypes represent 1950-1970 vintage buildings. The C prototypes are 1980 vintage buildings and the $D$ prototypes are 1990 vintage. For this study, we verified the $A$ and $B$ prototype characteristics and updated the $C$ and $D$ prototype descriptions based on the most current available data. In addition, we developed large versions (i.e., more floor area) of two prototypes, the $\mathrm{B} 1+$ and $\mathrm{D}+$ buildings. We provide more detail about representation of the building prototypes in Appendix A.

The main source of data for the A and B prototypes in the previous study was the 1980 and 1981 Residential Energy Consumption Surveys (RECS). The C prototype was developed using data from the National Association of Home Builders (NAHB) Surveys, 1978-1982. For the D prototype, the $C$ prototype was thermally improved using the Farm Home Administration (FHA) Thermal Performance Construction Standards and the U.S. Department of Housing and Urban Development (HUD) Minimum Property Standards as guidelines. We consulted similar databases in verifying and updating the AMS prototype descriptions and developing the new B1+ and D+ prototypes. However, we used the 1987 RECS data tape ${ }^{9}$ and the 1987 NAHB Builder's Survey ${ }^{10}$ as the primary data sources. We supplemented this information with building construction data from U.S. Census Bureau Reports ${ }^{16}$, and unpublished data from F.W. Dodge Corporation ${ }^{17,18}$ and NAHB. ${ }^{19,20}$

The survey results were processed statistically and cross-referenced to four major criteria: (1) location (census region, census division, or state) (2) year building was constructed, (3) number of stories in the building, and (4) thermal integrity of the building shell. Thus, eight building types in each of the 16 base cities, which combined represent approximately $35 \%$ of the single-family building population, were defined from this analysis as the number of building types and locations that most accurately characterized the sector. In Appendix B, we show the portion of the U.S. single-family building stock represented by the prototypes and how the representation is derived.

These generic building types are representative of different vintages (pre-1940s to 1990s), sizes (i.e., number of stories, average floor area, large floor area, etc.), and levels of thermal integrity for each of the nine census divisions and sixteen base cities. Each base city 
has eight prototypes, ranging from poorly insulated pre-1940s buildings to more energyefficient ones from the 1980s to large energy-efficient buildings of the 1990s. Each significant combination of climate type and geographically-based building tradition is represented by a base city.

\section{General Building Characteristics}

We compared the square footage values for prototypes $A$ and $B$ in the previous study with 1987 RECS data tape results stratified by vintage, census division, and number of stories. For the prototypes where the new data differed by $25 \%$ or more from the existing specifications, we changed the building size to match the newer data results. This affected only the prototypes with conditioned floor areas of less than $750 \mathrm{ft}^{2}$, found in the West North Central (B prototype), South Atlantic (A prototype), West South Central (A), and Mountain (A) census divisions. The new values were between 975 and $1200 \mathrm{ft}^{2}$. The values for all $A$ and B prototypes are provided in Table 2 . The wall and foundation types are as assumed in the previous study.

Table 2. General Specifications for A and B Prototypes

\begin{tabular}{|c|c|c|c|c|c|c|c|c|}
\hline $\begin{array}{l}\text { Census } \\
\text { Division }\end{array}$ & $\begin{array}{l}\text { Base } \\
\text { Cities }\end{array}$ & $\begin{array}{l}\text { Proto- } \\
\text { type }\end{array}$ & $\begin{array}{l}\text { Year } \\
\text { Built }\end{array}$ & $\begin{array}{l}\text { No. } \\
\text { Stories }\end{array}$ & $\begin{array}{c}\text { Floor Conditioned } \\
\text { Area }\left(\mathrm{ft}^{2}\right)\end{array}$ & $\left\{\begin{array}{l}\text { Window } \\
\text { Area }\left(\mathrm{ft}^{2}\right)\end{array}\right.$ & $\begin{array}{l}\text { Wall } \\
\text { Type }\end{array}$ & $\begin{array}{c}\text { Foundation } \\
\text { Type }\end{array}$ \\
\hline New England & Boston & $\begin{array}{l}\mathrm{A} \\
\mathrm{B}\end{array}$ & $\begin{array}{l}\text { pre 1940s } \\
1950-1970\end{array}$ & $\begin{array}{l}2 \\
2 \\
\end{array}$ & $\begin{array}{l}1440 \\
2220 \\
\end{array}$ & $\begin{array}{l}280 \\
430 \\
\end{array}$ & $\begin{array}{l}\text { Wood } \\
\text { Wood }\end{array}$ & $\begin{array}{l}\text { Bsmt } \\
\text { Bsmt }\end{array}$ \\
\hline Mid-Atlantic & New York & $\begin{array}{l}\text { A } \\
\text { B }\end{array}$ & $\begin{array}{c}\text { pre 1940s } \\
1950-1970\end{array}$ & $\begin{array}{l}2 \\
2\end{array}$ & $\begin{array}{l}1400 \\
1960\end{array}$ & $\begin{array}{l}277 \\
385\end{array}$ & $\begin{array}{l}\text { Wood } \\
\text { Wood }\end{array}$ & $\begin{array}{l}\text { Bsmt } \\
\text { Bsmt }\end{array}$ \\
\hline East North Central & Chicago & $\begin{array}{l}\mathrm{A} \\
\mathrm{B}\end{array}$ & $\begin{array}{l}\text { pre } 1940 \mathrm{~s} \\
1950-1970\end{array}$ & $\begin{array}{l}2 \\
1\end{array}$ & $\begin{array}{l}1580 \\
1380\end{array}$ & $\begin{array}{l}300 \\
264\end{array}$ & $\begin{array}{l}\text { Wood } \\
\text { Brick }\end{array}$ & $\begin{array}{l}\text { Bsmt } \\
\text { Bsmt }\end{array}$ \\
\hline West North Central & $\begin{array}{l}\text { Minneapolis } \\
\text { Kansas City }\end{array}$ & $\begin{array}{l}\text { A } \\
\text { B }\end{array}$ & $\begin{array}{l}\text { pre 1940s } \\
1950-1970\end{array}$ & $\begin{array}{l}2 \\
1\end{array}$ & $\begin{array}{l}1580 \\
1100\end{array}$ & $\begin{array}{l}310 \\
216\end{array}$ & $\begin{array}{l}\text { Wood } \\
\text { Wood }\end{array}$ & $\begin{array}{l}\text { Bsmt } \\
\text { Bsmt }\end{array}$ \\
\hline South Atlantic & $\begin{array}{l}\text { Washington } \\
\text { Atlanta } \\
\text { Miami }\end{array}$ & $\begin{array}{l}\mathrm{A} \\
\mathrm{B}\end{array}$ & $\begin{array}{l}\text { pre } 1940 \text { s } \\
1950-1970\end{array}$ & $\begin{array}{l}1 \\
1\end{array}$ & $\begin{array}{l}1165 \\
1415\end{array}$ & $\begin{array}{l}207 \\
249\end{array}$ & $\begin{array}{l}\text { Wood } \\
\text { Brick }\end{array}$ & $\begin{array}{l}\text { Crawl } \\
\text { Crawl }\end{array}$ \\
\hline West South Central & $\begin{array}{l}\text { fFort Worth } \\
\text { New Orleans }\end{array}$ & $\begin{array}{l}\mathrm{A} \\
\mathrm{B}\end{array}$ & $\begin{array}{l}\text { pre } 1940 \mathrm{~s} \\
1950-1970\end{array}$ & $\begin{array}{l}1 \\
1\end{array}$ & $\begin{array}{l}1055 \\
1390\end{array}$ & $\begin{array}{l}216 \\
286\end{array}$ & $\begin{array}{l}\text { Wood } \\
\text { Brick }\end{array}$ & $\begin{array}{l}\text { Slab } \\
\text { Slab }\end{array}$ \\
\hline Mountain & $\begin{array}{l}\text { Denver } \\
\text { Albuquerque } \\
\text { Phoenix }\end{array}$ & $\begin{array}{l}\mathrm{A} \\
\mathrm{B}\end{array}$ & $\begin{array}{l}\text { pre 1940s } \\
1950-1970\end{array}$ & $\begin{array}{l}1 \\
1\end{array}$ & $\begin{array}{r}975 \\
1080\end{array}$ & $\begin{array}{l}177 \\
196\end{array}$ & $\begin{array}{l}\text { Wood } \\
\text { Brick }\end{array}$ & $\begin{array}{l}\text { Bsmt } \\
\text { Slab }\end{array}$ \\
\hline Pacific North & Seattle & $\begin{array}{l}\mathrm{A} \\
\mathrm{B}\end{array}$ & $\begin{array}{l}\text { pre } 1940 \mathrm{~s} \\
1950-1970\end{array}$ & $\begin{array}{l}1 \\
1\end{array}$ & $\begin{array}{l}1400 \\
1390\end{array}$ & $\begin{array}{l}244 \\
242\end{array}$ & $\begin{array}{l}\text { Wood } \\
\text { Wood }\end{array}$ & $\begin{array}{l}\text { Crawl } \\
\text { Crawl }\end{array}$ \\
\hline Pacific South & $\begin{array}{l}\text { San Francisco } \\
\text { Los Angeles }\end{array}$ & $\begin{array}{l}\text { A } \\
\text { B }\end{array}$ & $\begin{array}{c}\text { pre 1940s } \\
1950-1970\end{array}$ & $\begin{array}{l}1 \\
1\end{array}$ & $\begin{array}{l}1400 \\
1390\end{array}$ & $\begin{array}{l}244 \\
242\end{array}$ & $\begin{array}{l}\text { Wood } \\
\text { Stucco }\end{array}$ & $\begin{array}{l}\text { Crawl } \\
\text { Crawl }\end{array}$ \\
\hline
\end{tabular}

For the 1980 s and 1990 s vintages, we developed new $C$ and D prototype characteristics based on current available data that is more representative of construction trends between 1980 
and 1989. We gathered square footage estimates for new single-family construction between 1980 and 1989 from the 1987 RECS data tape, U.S Census Bureau reports, the National Association of Home Builders (NAHB), and the F.W. Dodge Corporation. The Census reports for 1980-89 give mean and median square foot data for new construction by census region and for the U.S. as a whole. They also tabulate construction type - one story, two story, and split-level. Average square footage data for new construction, 1979-1988, on both state and national level were also provided to GRI by the NAHB. In addition, we also used state-specific data from the NAHB 1987 Builders Survey in developing construction type, foundation type, and average square footage data for 1980 s houses.

Figure 1 presents the various estimates for average floor area through the 1980 s, including Census Bureau, Dodge, and NAHB data. While the magnitudes differ, the plot shows that on a national level, floor area is constant from 1980-85, and then rises at constant rates from 35 to 70 square feet per year. Figure 2 shows Census Bureau estimates of construction type in the 1980s. The construction type is important because two-story houses are larger on the average than one story houses. The proportion of two-story houses has been increasing in all parts of the country.

We made estimates of average 1980 s square footage for each base city by combining Census Report square footage and construction type data (1980-89) and state-specific data from the 1987 NAHB Builder's Survey. We took the predominant construction type and average one-story and two-story square foot data for each state from the NAHB survey. We used the Census Report data to develop weighted averages of floor area for the 1980 s by census region. Using these two data sets, we calculated weighted average square foot estimates for one and two story buildings for each census region. For each state, we then chose the appropriate construction type and square footage from the respective census region. The $\mathrm{C}$ prototype construction type and floor areas are given in Table 3.

The 1990s, or D prototype, was assumed to be a slightly modified C prototype. Thus, average floor area was assumed to continue to increase into the 1990 s following the trend shown in Figure 1, allowing for the change in construction type as shown in Figure 2. To determine the impact of the trend in construction types on the average square footage data, we calculated the change in average square footage for each census region using the construction type percentages from the Census Bureau data and assumed one- and two-story square footage values taken from the 1987 NAHB builders survey database. We compared these calculated values to the change in mean square footage in Census Bureau reports over the same period. The difference between the two represents the change in average house size irrespective of the trend in construction types. The results show increases in floor area of 188 to 223 square feet between 1980 and 1989 when removing the effect of the change in proportion of one- and two-story houses. We added these values to the 1980s figures to arrive at the 1990 floor area estimates. Prototype floor areas for the D prototypes are given in Table 3. 
Figure 1. Average Floor Area for New Construction U.S. Single Family Buildings, 1980-1989

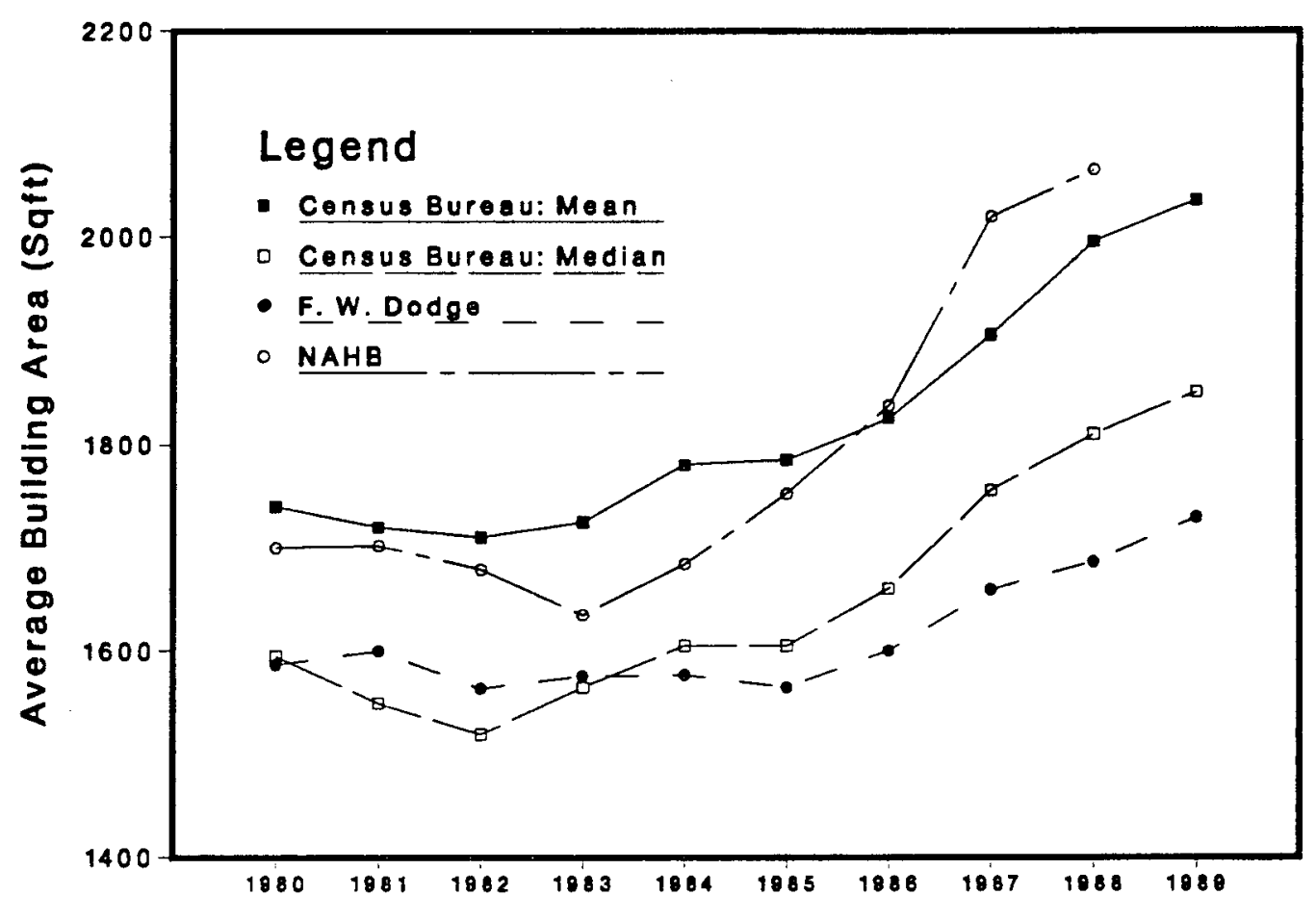

Figure 2. Construction Type for New Construction

U.S. Single Family Buildings, 1980-1989

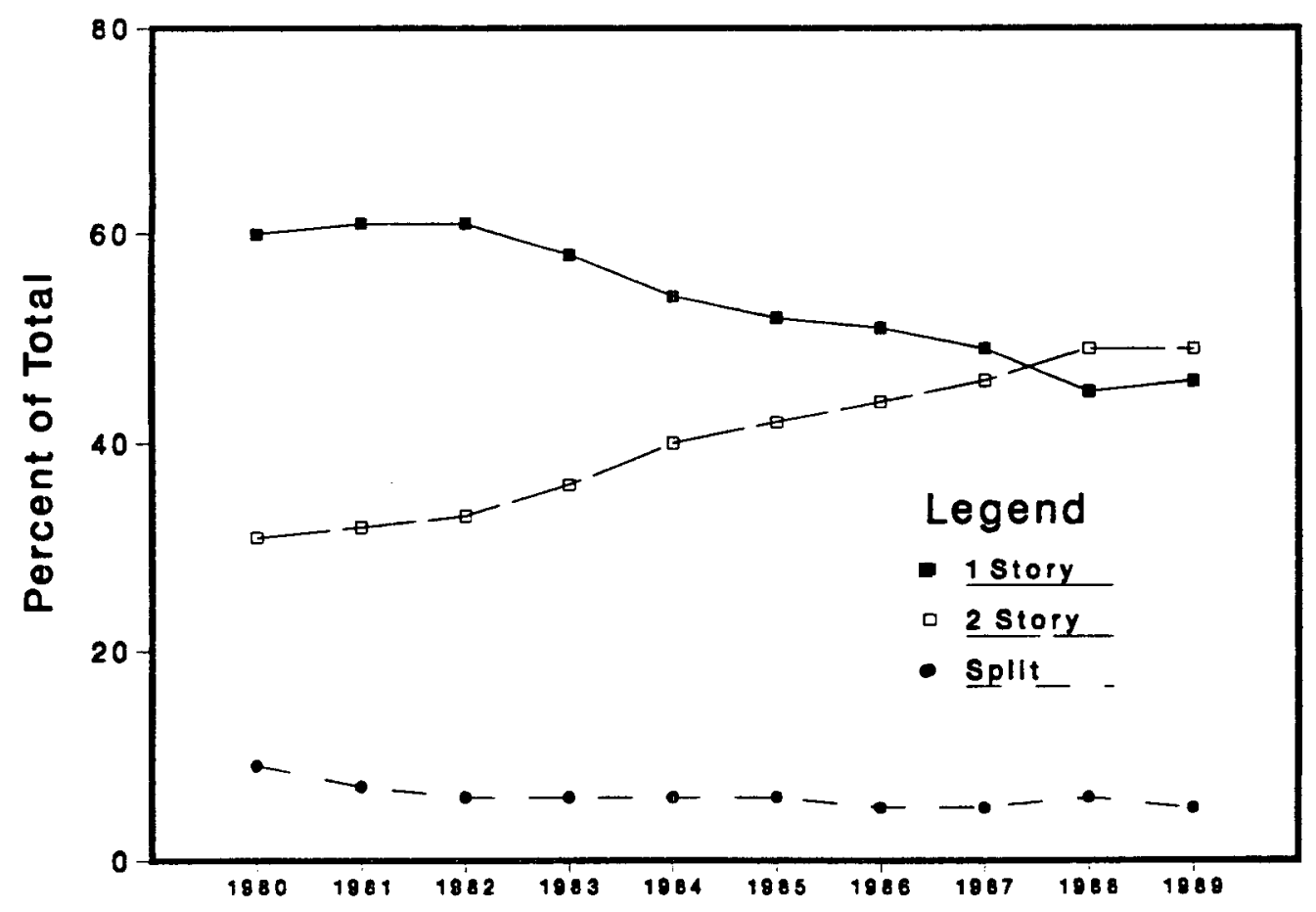


Table 3. General Specifications for $C$ and D Prototypes

\begin{tabular}{|c|c|c|c|c|c|c|c|}
\hline $\begin{array}{l}\text { Base } \\
\text { City }\end{array}$ & $\begin{array}{c}\text { Proto- } \\
\text { Type }\end{array}$ & $\begin{array}{l}\text { Year } \\
\text { Built }\end{array}$ & $\begin{array}{c}\text { No. } \\
\text { Stories }\end{array}$ & $\begin{array}{c}\text { Conditioned } \\
\text { Floor } \\
\text { Area }\left(\mathrm{ft}^{2}\right)\end{array}$ & $\begin{array}{l}\text { Window } \\
\text { Area }\left(\mathrm{ft}^{2}\right)\end{array}$ & $\begin{array}{l}\text { Wall } \\
\text { Type }\end{array}$ & $\begin{array}{c}\text { Foundation } \\
\text { Type }\end{array}$ \\
\hline Boston & $\begin{array}{l}\text { C } \\
\text { D }\end{array}$ & $\begin{array}{l}1980 \mathrm{~s} \\
1990 \mathrm{~s}\end{array}$ & $\begin{array}{l}2 \\
2 \\
\end{array}$ & $\begin{array}{l}2090 \\
2280 \\
\end{array}$ & $\begin{array}{l}261 \\
285 \\
\end{array}$ & $\begin{array}{l}\text { Wood } \\
\text { Wood }\end{array}$ & $\begin{array}{l}\text { Bsmt } \\
\text { Bsmt } \\
\end{array}$ \\
\hline New York & $\begin{array}{l}\text { C } \\
\text { D }\end{array}$ & $\begin{array}{l}1980 \mathrm{~s} \\
1990 \mathrm{~s}\end{array}$ & $\begin{array}{l}2 \\
2\end{array}$ & $\begin{array}{l}2090 \\
2280\end{array}$ & $\begin{array}{l}243 \\
265\end{array}$ & $\begin{array}{l}\text { Wood } \\
\text { Wood }\end{array}$ & $\begin{array}{l}\text { Bsmt } \\
\text { Bsmt }\end{array}$ \\
\hline Chicago & $\begin{array}{l}\mathrm{C} \\
\mathrm{D} \\
\end{array}$ & $\begin{array}{l}1980 \mathrm{~s} \\
1990 \mathrm{~s} \\
\end{array}$ & $\begin{array}{l}2 \\
2 \\
\end{array}$ & $\begin{array}{l}2220 \\
2420 \\
\end{array}$ & $\begin{array}{l}275 \\
300 \\
\end{array}$ & $\begin{array}{l}\text { Alum } \\
\text { Alum } \\
\end{array}$ & $\begin{array}{l}\text { Bsmt } \\
\text { Bsmt }\end{array}$ \\
\hline Minneapolis & $\begin{array}{l}C \\
D\end{array}$ & $\begin{array}{l}1980 \mathrm{~s} \\
1990 \mathrm{~s} \\
\end{array}$ & $\begin{array}{l}2 \\
2 \\
\end{array}$ & $\begin{array}{l}2220 \\
2420 \\
\end{array}$ & $\begin{array}{l}242 \\
264 \\
\end{array}$ & $\begin{array}{l}\text { Wood } \\
\text { Wood }\end{array}$ & $\begin{array}{l}\text { Bsmt } \\
\text { Bsmt } \\
\end{array}$ \\
\hline Kansas City & $\begin{array}{l}\mathrm{C} \\
\mathrm{D}\end{array}$ & $\begin{array}{l}1980 \mathrm{~s} \\
1990 \mathrm{~s}\end{array}$ & $\begin{array}{l}2 \\
2\end{array}$ & $\begin{array}{l}2220 \\
2420 \\
\end{array}$ & $\begin{array}{l}282 \\
307 \\
\end{array}$ & $\begin{array}{l}\text { Wood } \\
\text { Wood }\end{array}$ & $\begin{array}{l}\text { Bsmt } \\
\text { Bsmt }\end{array}$ \\
\hline Washington & $\begin{array}{l}\text { C } \\
D\end{array}$ & $\begin{array}{l}1980 \mathrm{~s} \\
1990 \mathrm{~s} \\
\end{array}$ & $\begin{array}{l}2 \\
2 \\
\end{array}$ & $\begin{array}{l}2180 \\
2390 \\
\end{array}$ & $\begin{array}{l}288 \\
316 \\
\end{array}$ & $\begin{array}{l}\text { Alum } \\
\text { Alum }\end{array}$ & $\begin{array}{l}\text { Bsmt } \\
\text { Bsmt }\end{array}$ \\
\hline Atlanta & $\begin{array}{l}\mathrm{C} \\
\mathrm{D}\end{array}$ & $\begin{array}{l}1980 \mathrm{~s} \\
1990 \mathrm{~s}\end{array}$ & $\begin{array}{l}2 \\
2 \\
\end{array}$ & $\begin{array}{l}2180 \\
2390 \\
\end{array}$ & $\begin{array}{l}264 \\
289 \\
\end{array}$ & $\begin{array}{l}\text { Wood } \\
\text { Wood }\end{array}$ & $\begin{array}{l}\text { Bsmt } \\
\text { Bsmt } \\
\end{array}$ \\
\hline Miami & $\begin{array}{l}\text { C } \\
\text { D }\end{array}$ & $\begin{array}{l}1980 \mathrm{~s} \\
1990 \mathrm{~s} \\
\end{array}$ & $\begin{array}{l}1 \\
1 \\
\end{array}$ & $\begin{array}{l}1620 \\
1830 \\
\end{array}$ & $\begin{array}{l}214 \\
242 \\
\end{array}$ & $\begin{array}{l}\text { Stucco } \\
\text { Stucco }\end{array}$ & $\begin{array}{l}\text { Slab } \\
\text { Slab } \\
\end{array}$ \\
\hline Fort Worth & $\begin{array}{l}\mathrm{C} \\
\mathrm{D}\end{array}$ & $\begin{array}{l}1980 \mathrm{~s} \\
1990 \mathrm{~s} \\
\end{array}$ & $\begin{array}{l}1 \\
1 \\
\end{array}$ & $\begin{array}{l}1620 \\
1830 \\
\end{array}$ & $\begin{array}{l}214 \\
242 \\
\end{array}$ & $\begin{array}{l}\text { Wood } \\
\text { Wood }\end{array}$ & $\begin{array}{l}\text { Slab } \\
\text { Slab } \\
\end{array}$ \\
\hline New Orleans & $\begin{array}{l}C \\
D\end{array}$ & $\begin{array}{l}1980 \mathrm{~s} \\
1990 \mathrm{~s} \\
\end{array}$ & $\begin{array}{l}1 \\
1\end{array}$ & $\begin{array}{l}1620 \\
1830 \\
\end{array}$ & $\begin{array}{l}214 \\
242 \\
\end{array}$ & $\begin{array}{l}\text { Brick } \\
\text { Brick }\end{array}$ & $\begin{array}{l}\text { Slab } \\
\text { Slab } \\
\end{array}$ \\
\hline Denver & $\begin{array}{l}\mathrm{C} \\
\mathrm{D}\end{array}$ & $\begin{array}{l}1980 \mathrm{~s} \\
1990 \mathrm{~s} \\
\end{array}$ & $\begin{array}{l}2 \\
2 \\
\end{array}$ & $\begin{array}{l}2070 \\
2290 \\
\end{array}$ & $\begin{array}{l}263 \\
291 \\
\end{array}$ & $\begin{array}{l}\text { Wood } \\
\text { Wood }\end{array}$ & $\begin{array}{l}\text { Bsmt } \\
\text { Bsmt }\end{array}$ \\
\hline Albuquerque & $\begin{array}{l}\mathrm{C} \\
\mathrm{D}\end{array}$ & $\begin{array}{l}1980 \mathrm{~s} \\
1990 \mathrm{~s} \\
\end{array}$ & $\begin{array}{l}1 \\
1 \\
\end{array}$ & $\begin{array}{l}1660 \\
1880 \\
\end{array}$ & $\begin{array}{l}179 \\
203 \\
\end{array}$ & $\begin{array}{l}\text { Stucco } \\
\text { Stucco }\end{array}$ & $\begin{array}{l}\text { Slab } \\
\text { Slab } \\
\end{array}$ \\
\hline Phoenix & $\begin{array}{l}\text { C } \\
\text { D }\end{array}$ & $\begin{array}{l}1980 \mathrm{~s} \\
1990 \mathrm{~s}\end{array}$ & $\begin{array}{l}1 \\
1 \\
\end{array}$ & $\begin{array}{l}1660 \\
1880 \\
\end{array}$ & $\begin{array}{l}179 \\
203 \\
\end{array}$ & $\begin{array}{l}\text { Stucco } \\
\text { Stucco } \\
\end{array}$ & $\begin{array}{l}\text { Slab } \\
\text { Slab } \\
\end{array}$ \\
\hline Seattle & $\begin{array}{l}\mathrm{C} \\
\mathrm{D}\end{array}$ & $\begin{array}{l}1980 \mathrm{~s} \\
1990 \mathrm{~s}\end{array}$ & $\begin{array}{l}2 \\
2 \\
\end{array}$ & $\begin{array}{l}2070 \\
2290 \\
\end{array}$ & $\begin{array}{l}383 \\
424 \\
\end{array}$ & $\begin{array}{l}\text { Wood } \\
\text { Wood }\end{array}$ & $\begin{array}{l}\text { Crawl } \\
\text { Crawl } \\
\end{array}$ \\
\hline San Francisco & $\begin{array}{l}C \\
D\end{array}$ & $\begin{array}{l}1980 \mathrm{~s} \\
1990 \mathrm{~s}\end{array}$ & $\begin{array}{l}2 \\
2 \\
\end{array}$ & $\begin{array}{l}2070 \\
2290 \\
\end{array}$ & $\begin{array}{l}325 \\
360 \\
\end{array}$ & $\begin{array}{l}\text { Stucco } \\
\text { Stucco } \\
\end{array}$ & $\begin{array}{l}\text { Slab } \\
\text { Slab } \\
\end{array}$ \\
\hline Los Angeles & $\begin{array}{l}C \\
D\end{array}$ & $\begin{array}{l}1980 \mathrm{~s} \\
1990 \mathrm{~s}\end{array}$ & $\begin{array}{l}2 \\
2 \\
\end{array}$ & $\begin{array}{l}2070 \\
2290 \\
\end{array}$ & $\begin{array}{l}325 \\
360 \\
\end{array}$ & $\begin{array}{l}\text { Stuccoo } \\
\text { Stucco } \\
\end{array}$ & $\begin{array}{l}\text { Slab } \\
\text { Slab }\end{array}$ \\
\hline
\end{tabular}

Two prototypes, the B1+ and D+, were developed to represent large houses with greater than average space conditioning loads. The RECS data provided the only source for determining the size of the large prototypes. Since the RECS data is provided as a sample of observations, it was possible to determine the range of building sizes within each of the prototype categories of region and vintage. The conditioned area for the large prototypes was defined as 
two standard deviations above the mean. For the B1+ prototype, we summarized the 1987 RECS conditioned area data for 1950-70 vintage buildings categorized by census division. The 1990 large house floor areas were estimated by adding two standard deviations for 1980 s vintage buildings to the 1990 average square footage. Because 1980 vintage homes were not well represented, we summarized the RECS data for 1980 vintage buildings as a whole for the country, stratifying only by construction type. We added twice the standard deviation to the average floor area in each construction type category. Other specifications, including the number of stories and foundation type, were taken as unchanged from the average buildings. The floor areas of the large houses are given in Table 4.

We also analyzed correlations between increasing house size and number of occupants, number of windows, and appliance saturations. We found that number of occupants was not significantly correlated with house size, but larger houses have more windows, and more of certain appliances (see for example Appendix B). These assumptions will be discussed below.

\section{Window Areas}

The window area estimates for the prototypes are crucial because of the significant effects of glazing on heat gain and loss in houses. For the A and B prototypes, we use the same window area assumed in the previous study. Where floor areas changed due to new data results, we recalculated window areas based on the same window area to floor area ratio.

For the C and D houses, the estimate was more difficult. Until 1983, the NAHB Builder Survey compiled window area as a percentage of floor area. These data from the 1981 Builder Survey were used to compute the window area for each the $C$ and $D$ prototype. However, the 1987 Survey only includes "number of windows" without reference to window size. The 1987 RECS also contains "number of windows" as a data base entry. We calculated window areas for the $C$ and $D$ prototypes using the same window area to floor area ratio used in the previous study. This assumes that window areas remain consistent through the 1980s and 1990s. For the large prototypes, the $\mathrm{B} 1+$ and $\mathrm{D}+$ houses, we used the same method for estimating window area, applying the appropriate percentage for each region/vintage combination to the prototype floor area. Window areas for each prototype are given in Tables 2-4.

\section{Building Thermal Integrity}

For the A and B prototypes, and the thermally improved A1 and B1 counterparts, we used the same wall, ceiling, floor, and foundation insulation levels and window glazing layers as specified in the previous study. ${ }^{1}$ The $A$ and $B$ prototypes are as-built and primarily uninsulated. The $A 1$ and $B 1$ prototypes represent retrofitted buildings from the same vintage. These two different levels of insulation for each were derived from an analysis of the 1980 RECS data tape. The data were separated into "low" and "high" insulation levels; the average of each was used as the "as-built" and "retrofitted" buildings. These specifications are summarized in Table 5. 
Table 4. General Specifications for B1+ and D+ Prototypes

\begin{tabular}{|c|c|c|c|c|c|c|c|}
\hline $\begin{array}{l}\text { Census } \\
\text { Region }\end{array}$ & \begin{tabular}{|l} 
Census \\
Division
\end{tabular} & $\begin{array}{l}\text { Base } \\
\text { City }\end{array}$ & $\begin{array}{l}\text { Proto- } \\
\text { Type }\end{array}$ & $\begin{array}{l}\text { Year } \\
\text { Built }\end{array}$ & $\begin{array}{c}\text { No. } \\
\text { Stories }\end{array}$ & $\begin{array}{c}\text { Floor } \\
\text { Area }\left(\mathrm{ft}^{2}\right)\end{array}$ & $\begin{array}{l}\text { Window } \\
\text { Area }\left(\mathrm{ft}^{2}\right)\end{array}$ \\
\hline \multirow[t]{2}{*}{ Northeast } & New England & Boston & $\begin{array}{l}\text { B1+ } \\
\text { D+ }\end{array}$ & $\begin{array}{c}1950-1970 \\
1990 \mathrm{~s}\end{array}$ & $\begin{array}{l}2 \\
2\end{array}$ & $\begin{array}{l}3934 \\
3850\end{array}$ & $\begin{array}{l}763 \\
481\end{array}$ \\
\hline & Mid Allantic & New York & $\begin{array}{c}\mathrm{Bl+} \\
\mathrm{D}+\end{array}$ & $\begin{array}{c}1950-1970 \\
1990 \mathrm{~s}\end{array}$ & $\begin{array}{l}2 \\
2 \\
\end{array}$ & $\begin{array}{l}3898 \\
3850 \\
\end{array}$ & $\begin{array}{l}764 \\
447 \\
\end{array}$ \\
\hline \multirow[t]{2}{*}{ North Central } & E N Central & Chicago & $\begin{array}{l}\text { B1+ } \\
\text { D+ }\end{array}$ & $\begin{array}{c}1950-1970 \\
1990 \mathrm{~s}\end{array}$ & $\begin{array}{l}1 \\
2\end{array}$ & $\begin{array}{l}3220 \\
3990\end{array}$ & $\begin{array}{l}615 \\
495\end{array}$ \\
\hline & W N Central & $\begin{array}{l}\text { Minneapolis } \\
\text { Kansas City }\end{array}$ & $\begin{array}{l}\mathrm{B} 1+ \\
\mathrm{D}+ \\
\mathrm{B} 1+ \\
\mathrm{D}+\end{array}$ & $\begin{array}{c}1950-1970 \\
1990 \mathrm{~s} \\
1950-1970 \\
1990 \mathrm{~s}\end{array}$ & $\begin{array}{l}1 \\
2 \\
1 \\
2\end{array}$ & $\begin{array}{l}2772 \\
3990 \\
2772 \\
3990\end{array}$ & $\begin{array}{l}543 \\
435 \\
543 \\
507\end{array}$ \\
\hline \multirow[t]{2}{*}{ South } & South Atlantic & $\begin{array}{l}\text { Washington } \\
\text { Atlanta } \\
\text { Miami }\end{array}$ & $\begin{array}{c}\mathrm{B} 1+ \\
\mathrm{D}+ \\
\mathrm{B} 1+ \\
\mathrm{D}+ \\
\mathrm{B} 1+ \\
\mathrm{D}+\end{array}$ & $\begin{array}{c}1950-1970 \\
1990 \mathrm{~s} \\
1950-1970 \\
1990 \mathrm{~s} \\
1950-1970 \\
1990 \mathrm{~s}\end{array}$ & $\begin{array}{l}1 \\
2 \\
1 \\
2 \\
1 \\
1\end{array}$ & $\begin{array}{l}2844 \\
3960 \\
2844 \\
3960 \\
2844 \\
3200\end{array}$ & $\begin{array}{l}500 \\
523 \\
500 \\
479 \\
500 \\
422\end{array}$ \\
\hline & W S Central & $\begin{array}{l}\text { Fort Worth } \\
\text { New Orleans }\end{array}$ & $\begin{array}{c}\mathrm{B} 1+ \\
\mathrm{D}+ \\
\mathrm{B} 1+ \\
\mathrm{D}+\end{array}$ & $\begin{array}{c}1950-1970 \\
1990 \mathrm{~s} \\
1950-1970 \\
1990 \mathrm{~s}\end{array}$ & $\begin{array}{l}1 \\
1 \\
1 \\
1\end{array}$ & $\begin{array}{l}2638 \\
3200 \\
2638 \\
3200 \\
\end{array}$ & $\begin{array}{l}543 \\
422 \\
543 \\
422 \\
\end{array}$ \\
\hline \multirow[t]{2}{*}{ West } & Mountain & $\begin{array}{l}\text { Denver } \\
\text { Albuquerque } \\
\text { Phoenix }\end{array}$ & $\begin{array}{c}\mathrm{B} 1+ \\
\mathrm{D}+ \\
\mathrm{B} 1+ \\
\mathrm{D}+ \\
\mathrm{B} 1+ \\
\mathrm{D}+\end{array}$ & $\begin{array}{c}1950-1970 \\
1990 \mathrm{~s} \\
1950-1970 \\
1990 \mathrm{~s} \\
1950-1970 \\
1990 \mathrm{~s}\end{array}$ & $\begin{array}{l}1 \\
2 \\
1 \\
1 \\
1 \\
1\end{array}$ & $\begin{array}{l}2362 \\
3860 \\
2362 \\
3250 \\
2362 \\
3250 \\
\end{array}$ & $\begin{array}{l}430 \\
490 \\
430 \\
351 \\
430 \\
351\end{array}$ \\
\hline & Pacific & $\begin{array}{l}\text { Seattle } \\
\text { San Francisco } \\
\text { Los Angeles }\end{array}$ & $\begin{array}{c}\mathrm{B} 1+ \\
\mathrm{D}+ \\
\mathrm{B} 1+ \\
\mathrm{D}+ \\
\mathrm{B} 1+ \\
\mathrm{D}+\end{array}$ & $\begin{array}{c}1950-1970 \\
1990 \mathrm{~s} \\
1950-1970 \\
1990 \mathrm{~s} \\
1950-1970 \\
1990 \mathrm{~s}\end{array}$ & $\begin{array}{l}1 \\
2 \\
1 \\
2 \\
1 \\
2\end{array}$ & $\begin{array}{l}2479 \\
3860 \\
2479 \\
3860 \\
2479 \\
3860 \\
\end{array}$ & $\begin{array}{l}431 \\
714 \\
431 \\
606 \\
431 \\
606\end{array}$ \\
\hline
\end{tabular}

For the $\mathrm{C}$ prototypes, we chose average insulation levels for each building component in each base city derived from the 1987 NAHB Builder's Survey. We checked these results for each base city with the data from the surrounding states, and also with published data summaries from NAHB representing the construction years of 1986 and $1987 .{ }^{19}$ For the D prototypes, we upgraded the $C$ prototype thermal integrities based on compliance with the proposed ASHRAE 90.2P energy-efficiency standard. ${ }^{11}$ Each building component (roof, wall, foundation, floor, windows, etc.) was made in compliance with the ASHRAE code. The insulation 
Table 5. Conservation Parameters for A and B Prototypes

\begin{tabular}{|c|c|c|c|c|c|c|c|}
\hline \multirow{2}{*}{$\begin{array}{l}\text { Census } \\
\text { Division }\end{array}$} & \multirow{2}{*}{$\begin{array}{l}\text { Proto- } \\
\text { type }\end{array}$} & \multirow{2}{*}{$\begin{array}{l}\text { Year } \\
\text { Built }\end{array}$} & \multicolumn{3}{|c|}{ R-Values $\left(\mathrm{hr}-\mathrm{ft}^{2}-{ }^{\circ} \mathrm{F} / \mathrm{Bru}\right)$} & \multirow{2}{*}{$\begin{array}{l}\text { Glazing } \\
\text { Layers }\end{array}$} & \multirow{2}{*}{$\begin{array}{l}\text { Foundation } \\
\text { Insulation }\end{array}$} \\
\hline & & & Wall & Ceiling & Floor & & \\
\hline \multirow[t]{4}{*}{ New England } & $\mathbf{A}$ & pre 1940 s & 0 & 0 & 0 & 2 & none \\
\hline & Al & pre 1940 s & 7 & 22 & 0 & 2 & none \\
\hline & $\mathbf{B}$ & $1950-1970$ & 0 & 22 & 0 & 2 & none \\
\hline & B1 & $1950-1970$ & 7 & 22 & 0 & 2 & none \\
\hline \multirow[t]{4}{*}{ Mid-Allantic } & $\mathbf{A}$ & pre 1940 s & 0 & 0 & 0 & 2 & none \\
\hline & Al & pre $1940 \mathrm{~s}$ & 7 & 7 & 0 & 2 & none \\
\hline & $\mathbf{B}$ & $1950-1970$ & 0 & 7 & 0 & 2 & none \\
\hline & B1 & $1950-1970$ & 7 & 11 & 0 & 2 & none \\
\hline \multirow[t]{4}{*}{ East North Central } & $A$ & pre 1940 s & $\overline{0}$ & 0 & 0 & 2 & none \\
\hline & $\mathrm{Al}$ & pre 1940 s & 7 & 11 & 0 & 2 & none \\
\hline & B & $1950-1970$ & 0 & 11 & 0 & 2 & none \\
\hline & B1 & $1950-1970$ & 7 & 19 & 0 & 2 & none \\
\hline \multirow[t]{4}{*}{ West North Central } & $A$ & pre 1940 s & 0 & 0 & 0 & 2 & none \\
\hline & $\mathrm{Al}$ & pre 1940 s & 7 & 7 & 0 & 2 & none \\
\hline & $\mathbf{B}$ & $1950-1970$ & 0 & 7 & 0 & 2 & none \\
\hline & B1 & $1950-1970$ & 7 & 22 & 0 & 2 & none \\
\hline \multirow[t]{4}{*}{ South Atlantic } & $\bar{A}$ & pre 1940 s & 0 & 0 & 0 & 2 & none \\
\hline & Al & pre 1940s & 7 & 7 & 0 & 2 & none \\
\hline & B & $1950-1970$ & 0 & 7 & 0 & 2 & none \\
\hline & B1 & $1950-1970$ & 7 & 11 & 0 & 2 & none \\
\hline \multirow[t]{4}{*}{ West South Central } & A & pre $1940 \mathrm{~s}$ & 0 & 0 & 0 & 2 & none \\
\hline & Al & pre 1940s & 7 & 7 & 0 & 2 & none \\
\hline & B & $1950-1970$ & 0 & 7 & 0 & 2 & none \\
\hline & B1 & $1950-1970$ & 7 & 19 & 0 & 2 & none \\
\hline \multirow[t]{4}{*}{ Mountain } & A & pre 1940 s & 0 & 0 & 0 & 2 & none \\
\hline & A1 & pre 1940 s & 7 & 11 & 0 & 2 & none \\
\hline & B & $1950-1970$ & 0 & 11 & 0 & 2 & none \\
\hline & B1 & $1950-1970$ & 7 & 11 & 0 & 2 & none \\
\hline \multirow[t]{4}{*}{ Pacific North } & A & pre $1940 \mathrm{~s}$ & 0 & 0 & 0 & 2 & none \\
\hline & Al & pre $1940 \mathrm{~s}$ & 7 & 11 & 0 & 2 & none \\
\hline & B & $1950-1970$ & 0 & 11 & 0 & 2 & none \\
\hline & B1 & $1950-1970$ & 7 & 19 & 0 & 2 & none \\
\hline \multirow[t]{4}{*}{ Pacific South } & A & pre $1940 \mathrm{~s}$ & 0 & 0 & 0 & 1 & none \\
\hline & Al & pre 1940 s & 7 & 7 & 0 & 1 & none \\
\hline & $\mathbf{B}$ & $1950-1970$ & $\mathbf{0}$ & 7 & 0 & 1 & none \\
\hline & B1 & $1950-1970$ & 7 & 11 & 0 & 1 & none \\
\hline
\end{tabular}

specifications for the $\mathrm{C}$ and $\mathrm{D}$ prototypes level are given in Table 6 . Conservation specifications for the large prototypes were assumed to be the same as for the average prototypes of the same vintage. 
For prototypes with basements, we made assumptions about whether the insulation was located in the floor or on the basement walls. Where basement wall insulation was predominant in the Builder Survey data, we simulated basement wall insulation in the $C$ prototypes. In all other cases, we simulated insulation in the floor cavity.

Table 6. Conservation Parameters for C and D Prototypes

\begin{tabular}{|c|c|c|c|c|c|c|c|c|}
\hline $\begin{array}{l}\text { Census } \\
\text { Division }\end{array}$ & $\begin{array}{l}\text { Base } \\
\text { City }\end{array}$ & $\begin{array}{c}\text { Proto- } \\
\text { type }\end{array}$ & $\begin{array}{l}\text { Year } \\
\text { Built }\end{array}$ & $\begin{array}{r}\text { R-v } \\
\text { Wall }\end{array}$ & $\begin{array}{l}\text { ues (hr-ft } \\
\text { Ceiling }\end{array}$ & $\begin{array}{c}\text { F/Btu) } \\
\text { Floor }\end{array}$ & $\begin{array}{l}\text { Glazing } \\
\text { Layers }\end{array}$ & $\begin{array}{l}\text { Foundation } \\
\text { Insulation }\end{array}$ \\
\hline New England & Boston & $\begin{array}{l}\mathrm{C} \\
\mathrm{D}\end{array}$ & $\begin{array}{l}1980 \mathrm{~s} \\
1990 \mathrm{~s}\end{array}$ & $\begin{array}{l}13 \\
16\end{array}$ & $\begin{array}{l}27 \\
28\end{array}$ & $\begin{array}{r}0 \\
19\end{array}$ & $\begin{array}{l}2 \\
3\end{array}$ & $\begin{array}{l}\text { none } \\
\text { none }\end{array}$ \\
\hline Mid Atlantic & New York & $\begin{array}{l}C \\
D\end{array}$ & $\begin{array}{l}1980 \mathrm{~s} \\
1990 \mathrm{~s}\end{array}$ & $\begin{array}{l}13 \\
16\end{array}$ & $\begin{array}{l}27 \\
28\end{array}$ & $\begin{array}{l}19 \\
19\end{array}$ & $\begin{array}{l}2 \\
3\end{array}$ & $\begin{array}{l}\text { none } \\
\text { none }\end{array}$ \\
\hline East North Central & Chicago & $\begin{array}{l}\text { C } \\
\text { D }\end{array}$ & $\begin{array}{l}1980 \mathrm{~s} \\
1990 \mathrm{~s}\end{array}$ & $\begin{array}{l}13 \\
16\end{array}$ & $\begin{array}{l}32 \\
32\end{array}$ & $\begin{array}{r}0 \\
19\end{array}$ & $\begin{array}{l}2 \\
3\end{array}$ & $\begin{array}{l}\text { none } \\
\text { none }\end{array}$ \\
\hline West North Central & $\begin{array}{l}\text { Minneapolis } \\
\text { Kansas City }\end{array}$ & $\begin{array}{l}\text { C } \\
D \\
C \\
D\end{array}$ & $\begin{array}{l}1980 \mathrm{~s} \\
1990 \mathrm{~s} \\
1980 \mathrm{~s} \\
1990 \mathrm{~s}\end{array}$ & $\begin{array}{l}19 \\
24 \\
11 \\
16 \\
\end{array}$ & $\begin{array}{l}32 \\
48 \\
29 \\
29\end{array}$ & $\begin{array}{r}0 \\
19 \\
0 \\
19 \\
\end{array}$ & $\begin{array}{l}2 \\
3 \\
2 \\
3\end{array}$ & $\begin{array}{c}\text { R-5 } 4 \mathrm{ft} \text { bsmt wall } \\
\text { none } \\
\text { none } \\
\text { none }\end{array}$ \\
\hline South Atlantic & $\begin{array}{l}\text { Washington } \\
\text { Atlanta } \\
\text { Miami }\end{array}$ & $\begin{array}{l}C \\
D \\
C \\
D \\
C \\
D\end{array}$ & $\begin{array}{l}1980 \mathrm{~s} \\
1990 \mathrm{~s} \\
1980 \mathrm{~s} \\
1990 \mathrm{~s} \\
1980 \mathrm{~s} \\
1990 \mathrm{~s}\end{array}$ & $\begin{array}{l}13 \\
16 \\
11 \\
16 \\
11 \\
16\end{array}$ & $\begin{array}{l}30 \\
30 \\
27 \\
28 \\
25 \\
28\end{array}$ & $\begin{array}{r}19 \\
19 \\
19 \\
19 \\
0 \\
0\end{array}$ & $\begin{array}{l}2 \\
3 \\
2 \\
2 \\
1 \\
1\end{array}$ & \begin{tabular}{|c|} 
none \\
none \\
none \\
none \\
none \\
R-5 2 ft. slab edge
\end{tabular} \\
\hline West South Central & $\begin{array}{l}\text { Fort Worth } \\
\text { New Orleans }\end{array}$ & $\begin{array}{l}\mathrm{C} \\
\mathrm{D} \\
\mathrm{C} \\
\mathrm{D}\end{array}$ & $\begin{array}{l}1980 \mathrm{~s} \\
1990 \mathrm{~s} \\
1980 \mathrm{~s} \\
1990 \mathrm{~s} \\
\end{array}$ & $\begin{array}{l}11 \\
16 \\
11 \\
16\end{array}$ & $\begin{array}{l}27 \\
28 \\
19 \\
28 \\
\end{array}$ & $\begin{array}{l}0 \\
0 \\
0 \\
0\end{array}$ & $\begin{array}{l}1 \\
1 \\
1 \\
1\end{array}$ & $\begin{array}{c}\text { R-5 } 2 \mathrm{fL} \text { slab edge } \\
\text { R-5 } 2 \mathrm{fL} \text { slab edge } \\
\text { none } \\
\text { R-5 } 2 \mathrm{fL} \text { slab edge }\end{array}$ \\
\hline Mountain & $\begin{array}{l}\text { Denver } \\
\text { Albuquerque } \\
\text { Phoenix }\end{array}$ & $\begin{array}{l}C \\
D \\
C \\
D \\
C \\
D\end{array}$ & \begin{tabular}{l|}
$1980 \mathrm{~s}$ \\
$1990 \mathrm{~s}$ \\
$1980 \mathrm{~s}$ \\
$1990 \mathrm{~s}$ \\
$1980 \mathrm{~s}$ \\
$1990 \mathrm{~s}$
\end{tabular} & $\begin{array}{l}13 \\
16 \\
13 \\
16 \\
13 \\
16\end{array}$ & $\begin{array}{l}31 \\
31 \\
29 \\
29 \\
27 \\
28\end{array}$ & $\begin{array}{r}11 \\
19 \\
0 \\
0 \\
0 \\
0\end{array}$ & $\begin{array}{l}2 \\
3 \\
2 \\
3 \\
2 \\
2\end{array}$ & $\begin{array}{c}\text { none } \\
\text { none } \\
\text { R-5 } 2 \mathrm{fL} \text { slab edge } \\
\text { R-5 } 2 \mathrm{ft} \text {. slab edge } \\
\text { none } \\
\text { R-5 } 2 \mathrm{ft} \text {. slab edge }\end{array}$ \\
\hline Pacific & $\begin{array}{l}\text { Seattle } \\
\text { San Francisco } \\
\text { Los Angeles }\end{array}$ & $\begin{array}{l}\text { C } \\
D \\
C \\
D \\
C \\
D\end{array}$ & $\begin{array}{l}1980 \mathrm{~s} \\
1990 \mathrm{~s} \\
1980 \mathrm{~s} \\
1990 \mathrm{~s} \\
1980 \mathrm{~s} \\
1990 \mathrm{~s}\end{array}$ & $\begin{array}{l}11 \\
16 \\
11 \\
16 \\
11 \\
16\end{array}$ & $\begin{array}{l}32 \\
32 \\
25 \\
28 \\
25 \\
25\end{array}$ & $\begin{array}{r}19 \\
19 \\
0 \\
0 \\
0 \\
0\end{array}$ & $\begin{array}{l}2 \\
3 \\
2 \\
2 \\
2 \\
2\end{array}$ & $\begin{array}{c}\text { none } \\
\text { none } \\
\text { none } \\
\text { R-5 } 2 \mathrm{fL} \text { slab edge } \\
\text { none } \\
\text { none }\end{array}$ \\
\hline
\end{tabular}

In addition to these generic building characterizations, numerous other assumptions are needed before complete models of prototype buildings can be developed and used as input to 
the DOE-2 simulations. For example, factors such as building geometry, average window shading and window operations, and shading from adjacent buildings are not part of the RECS data. We relied on our previous studies of residential buildings to develop the necessary DOE-2 inputs for these parameters as well as several others described below. $6,21,22$

\section{Building Geometry}

The prototype descriptions specified the numbers of floors, foundation type, and conditioned floor area in each prototype building, but not the architectural layout of the buildings. To transform these general descriptions into DOE-2 input files, we made assumptions about the architecture of typical single-family detached buildings depending on their climate and building size. The intent was not to create a detailed hypothetical building, but to capture average thermal conditions common to single-family buildings.

The dimensions of the A and B prototype buildings were taken from the AMS input files. For the C, D, D+, and B1+ prototypes, we used a standard width of $28 \mathrm{feet}$, which is a typical roof truss dimension. This gave some unusually long dimensions for the larger prototypes. While these long dimensions do not represent any actual building, thermally the building can be thought of as pieces arranged in L-shapes or courtyard shapes. The exposed foundation length and wall area are the same for the long building as the contorted building.

For the C, D, and D+ prototypes, we also modeled an attached, uninsulated two-car garage with a slab floor. The attached wall area was 180 square feet for one story and 240 square feet for two story prototypes, with a garage floor area of 460 square feet.

\section{Infiltration}

The effects of infiltration on building heating and cooling loads were simulated using the Sherman-Grimsrud model. ${ }^{23}$ This is a simplified physical model developed at LBL for air infiltration in residential buildings. The only information needed for the model is the leakage of the building. The leakage quantities, expressed in terms of effective areas, are the total leakage areas of the wall, floor and ceiling. Weather parameters used in the model include mean wind speed, terrain class, and average temperature difference. The model separates infiltration into two distinct parts: stack and wind-regimes. Each regime is treated separately, with a sharp transition between the two. The model has been tested with data from several sites that differ in climate and construction methods. ${ }^{23}$

We based the assumed effective-leakage-areas (ELA) on measured single-family results published in the literature and previous studies of single family building simulation. ${ }^{6,24}$ Based on engineering judgment, we assumed older buildings had more leakage than those built later. For the pre-1940s A prototypes, we assumed an average fractional-leakage-area of 0.0009 (leakage area/floor area) and for the 1950-1970 prototypes we assumed a fractional-leakagearea of 0.0007 . In addition, we assumed the "retrofit" prototypes, A1 and B1, would be tighter 
than the as-built buildings (ELA $=0.0008$ and 0.0006 , respectively). Because the ELA is dependent on fioor area, we used the same ELA for the large houses as the average prototype for the same vintage. We assumed the $C$ prototype would be slightly tighter than earlier prototypes, with a fractional leakage area of 0.0005 . For the $D$ and D+ prototypes, we used the climate-specific guidelines in the ASHRAE Standard 119 for air leakage to upgrade the 1980 s prototype numbers to meet the ASHRAE Standard. ${ }^{25}$ This affected only Boston, New York, Chicago, Kansas City, and Denver (leakage area of 0.00046) and Minneapolis (leakage area of 0.00033).

Since the net infiltration into a building depends not only on its physical characteristics, but also on the shielding effects of its surroundings, we simulated the surrounding areas as typical residential neighborhoods for all prototypes and in all base cities. For the inputs to the Sherman-Grimsrud model in the DOE-2 simulations we used a shielding-coefficient of 0.19 , terrain parameter 1 of 0.85 , and terrain parameter 2 of 0.20 .

\section{Shading}

The solar gain entering a building depends on the orientation of the windows and walls, the amount of shading due to adjacent buildings, and characteristics and operations of window shades, if available. In this study, we modeled average, rather than typical, building conditions. We created an average building orientation by apportioning the amounts of walls, windows, and doors equally in the four cardinal directions. Similarly, we considered average amounts of shading from two adjacent buildings by modeling semi-transparent shading surfaces with a transmittance of 0.50 with the same height as, and located on all sides of, the prototype building. These building shades were sited 20 feet away for the suburban areas. We accounted for average window shade operations by using a glass shading coefficient of 0.80 during the winter and 0.60 during the summer. We distinguished between the summer and winter operating modes by adding a special Fortran function into the DOE-2 input that counted the number of cooling degree-days over the previous four days (see sample DOE-2 input files in Appendix C).

\section{Foundations}

Since the existing DOE-2 program does not adequately model the building-to-ground interface, we used a Fortran function to incorporate into DOE-2 heat fluxes calculated by a two-dimensional finite difference program developed by the Underground Space Center at the University of Minnesota. We used this program to simulate, on a daily time-step basis, the dynamic behavior of a representative one-foot vertical cross-section of the foundation and surrounding soil extending 50 feet down and 30 feet out from the building.

The finite difference simulations yielded daily fluxes at each node of the finite difference grid for the representative section. We then integrated these fiuxes over the "foot-print" of the prototype buildings to produce files of average hourly fluxes through their underground 
surfaces for each day of the year. During the DOE-2.1 simulation, these fluxes are read as a function in LOADS, replacing the standard DOE-2 underground flux calculation. A more complete description of this method is given elsewhere. ${ }^{26}$

\section{OPERATING ASSUMPTIONS}

Operating assumptions refer to those actions affecting building energy use that are under the control of the occupants. These include such factors as temperature settings, night thermostat setback, window operations (i.e., opening and closing), and intemal loads due to occupants and appliances. For this study, we defined the most average, rather than the optimal, operating conditions in single-family units based on survey data and other studies.

\section{Thermostat Settings}

We modeled the prototype buildings with the same thermostat settings. The heating set point in the living spaces was held at $70^{\circ} \mathrm{F}$ during the day, with a 8 -hour setback to $64^{\circ} \mathrm{F}$ between 11 p.m. and 7 a.m. These assumptions correspond to data from recent RECS surveys that report the mean household temperature in units with heating controls was $69.3^{\circ} \mathrm{F}$; over $64 \%$ of the respondents turned down their thermostats at night by 3 to 10 degrees. $^{9}$ They also agree with information on thermostat management from other sources. ${ }^{27,28,29}$

To account for natural ventilation, we modeled average window operations by building occupants as follows. During the heating season, window venting (i.e., opening windows) was assumed when indoor temperatures rose above $78^{\circ} \mathrm{F}$, while during the cooling season venting was assumed down to a level of $72^{\circ} \mathrm{F}$ if the following criteria were met: (1) the outdoor temperature was lower than indoor temperatures and not higher than $78^{\circ} \mathrm{F}$, (2) the enthalpy of outdoor air was less than that of indoor air, and (3) the cooling load that hour could be met totally through window venting. Since occupants typically do not adjust windows after going to bed, window conditions were assumed to be fixed between 11 p.m. and 7 a.m. unless indoor temperatures dropped below the heating set point.

\section{Internal Loads}

Under normal occupancy, a building collects heat, which is termed the internal load, released by people, appliances, and lighting. This intemal load reduces a building's heating loads during the winter, but adds to its cooling loads during the summer. After reviewing a previous LBL study of internal loads in single-family residences, ${ }^{6}$ we developed a method for deriving intemal loads values for the prototype buildings. We combined assumptions of occupancy levels, schedules, and typical occupancy heat gains; appliance saturations, appliance heat gain schedules, and typical appliance energy use; and annual lighting energy and lighting schedules. 
For average occupancy levels, we assumed 3 persons per household in each prototype based on previous LBL studies ${ }^{6}$ and an analysis of the 1987 RECS tape which showed an average of 3.1 occupants per household. We used occupant heat gain of $230 \mathrm{Btu} / \mathrm{hr}$ sensible and $190 \mathrm{Btu} / \mathrm{hr}$ latent per person from ASHRAE. ${ }^{30}$ These values are equivalent to seated, light work and match the numbers used in the multifamily study. ${ }^{4}$ When combined with the occupant load profile, the total occupant heat gain is 15,200 Btu/day for each prototype ( 8360 Btu/day sensible, $6840 \mathrm{Btu} /$ day latent).

We summarized the 1987 RECS data to develop average appliance saturations for calculating internal gains. We stratified the RECS single-family data by the nine census divisions, and calculated average appliance saturations across all vintages of single-family detached dwellings. RECS does not include clothes washers, so based on clothes dryer saturations between 0.7 and 0.9 we used a saturation of 1.0 for clothes washers. We also assumed a saturation of 1.0 for ovens/ranges. For cooking fuel, RECS data give the saturation of electric and gas cooking. Electric predominates in all census divisions except for the West South Central. RECS also gives separate saturations for electric and gas dryers. In calculating internal gains, we assumed that clothes dryers and cooking were electric. The results also show multiple refrigerators per household. We assumed the primary refrigerator was of new vintage while the fractional number of second refrigerators were assumed to be an older variety. The appliance saturations in each census division are given in Table 7 .

We further analyzed the RECS 1987 data base to determine the relationship between appliance saturation and building size, in order to more closely characterize the large house appliance load. The only appliances with a strong relationship between appliance saturation and conditioned square footage were refrigerators and black and white and color televisions. For the large houses, we increased the appliance saturations by $0.15,0.19$, and 0.32 , respectively, per 1000 square feet of increase in floor area.

We combined these appliance saturations with typical appliance energy use values taken from several sources, including previous LBL work, RECS summaries, the LBL Residential Energy Model, and the 1987 National Appliance Energy Conservation Act (NAECA). ${ }^{6,13,31,32,33}$ For the prototypes built before 1990, we used energy use values representative of typical 1980s stock appliances. For the 1990 s prototypes, we used appliance energy consumption values modified to meet the NAECA code where applicable. In 1993, new. federal appliance efficiency standards will reduce the energy consumption of home appliances, and thus will lower internal heat gains. These standards will affect refrigerators, freezers, dishwashers, clothes washers, and dryers. Miscellaneous small appliance usage and intemal gains from water heater standby losses and use were also included. All appliance energy use assumptions are provided in Table 8 . We used annual lighting energy of $1 \mathrm{kWh} / \mathrm{ft}^{2}$, which we have used for previous single-family and multifamily studies. 
Table 7. 1987 RECS Data Tape Results for Single-Family Detached Dwellings Appliance Saturations and Types by Census Division

\begin{tabular}{|l|c|c|c|c|c|c|c|c|c|}
\hline Appliance & $\begin{array}{c}\text { New } \\
\text { England }\end{array}$ & $\begin{array}{c}\text { Mid } \\
\text { Alantic }\end{array}$ & $\begin{array}{c}\text { E. North } \\
\text { Central }\end{array}$ & $\begin{array}{c}\text { W. North } \\
\text { Central }\end{array}$ & $\begin{array}{c}\text { South } \\
\text { Allantic }\end{array}$ & $\begin{array}{c}\text { E. South } \\
\text { Central }\end{array}$ & $\begin{array}{c}\text { W. South } \\
\text { Central }\end{array}$ & Mountain & Pacific \\
\hline Refriger ator & 1.23 & 1.27 & 1.23 & 1.19 & 1.14 & 1.10 & 1.12 & 1.13 & 1.18 \\
Range/Oven* & 1.00 & 1.00 & 1.00 & 1.00 & 1.00 & 1.00 & 1.00 & 1.00 & 1.00 \\
Dishwasher & .55 & .51 & .34 & .42 & .36 & .41 & .45 & .59 & .46 \\
Clothes Washer* & 1.00 & 1.00 & 1.00 & 1.00 & 1.00 & 1.00 & 1.00 & 1.00 & 1.00 \\
Electric Dryer & .67 & .62 & .49 & .65 & .56 & .71 & .56 & .68 & .54 \\
Gas Dryer & .15 & .24 & .30 & .21 & .12 & .02 & .22 & .12 & .27 \\
FF Freezer & .10 & .15 & .16 & .15 & .17 & .21 & .20 & .19 & .21 \\
Manual Freezer & .27 & .35 & .39 & .46 & .27 & .37 & .37 & .33 & .24 \\
B/W TV & .67 & .61 & .53 & .54 & .60 & .55 & .52 & .49 & .49 \\
Color TV & 1.37 & 1.56 & 1.35 & 1.30 & 1.29 & 1.25 & 1.42 & 1.36 & 1.45 \\
\hline Refr type 1 & FFF & FFF & FFF & FFF & FFF & FFF & FFF & FFF & FFF \\
Refr type 2 & Man & Man & Man & Man & Man & FFF & FFF & Man & Man \\
Cooking Fuel & Elec & Elec & Elec & Elec & Elec & Elec & Gas & Elec & Elec \\
\hline
\end{tabular}

FFF $=$ Full Frost Free Freezer

Auto $=$ Automatic Defrost Freezer

Man = Manual Defrost Freezer

- Not from RECS data

Not all heat generated by appliances is input to the conditioned space. Therefore, we made assumptions about the average location of appliances and venting of the generated heat. We assumed all of the heat generated by the dishwasher and clothes washer and most of the dryer heat and hot water use would be dissipated outside of the dwelling. We also assumed some of the refrigerators, freezers, and water heaters would, on average, be located in unconditioned spaces. For the DOE-2 simulations, we added this portion of the intemal gains to the basement, if existing, or else to the garage. Lastly, $10 \%$ of the lighting energy was assigned to outdoor lighting. We also assigned latent portions to those end uses which generate moisture. These assumptions are included in Table 8 . Calculated internal gains values are given in Table 9.

The intemal gains profiles were taken from a Califomia Energy Commission (CEC) study, which includes a daily profile for occupants, appliances, and lighting with seasonal modifications for appliances and lighting. ${ }^{34}$ Average daily profiles are shown in Figure 3. Using the CEC lighting schedule, the peak lighting load is $0.43 \mathrm{Watts} / \mathrm{ft}^{2}$. The peak appliance loads for the prototypes range from $1.03 \mathrm{~kW}$ for the large ptototypes to $0.79 \mathrm{~kW}$ for the average size 1990s prototypes. The effect of the change in appliance energy consumption for 1990 s houses is to decrease internal gains from appliances by about $17 \%$, with total internal gains decreasing by about $9 \%$. 
Figure 3. Internal Loads Profile for Prototype Buildings
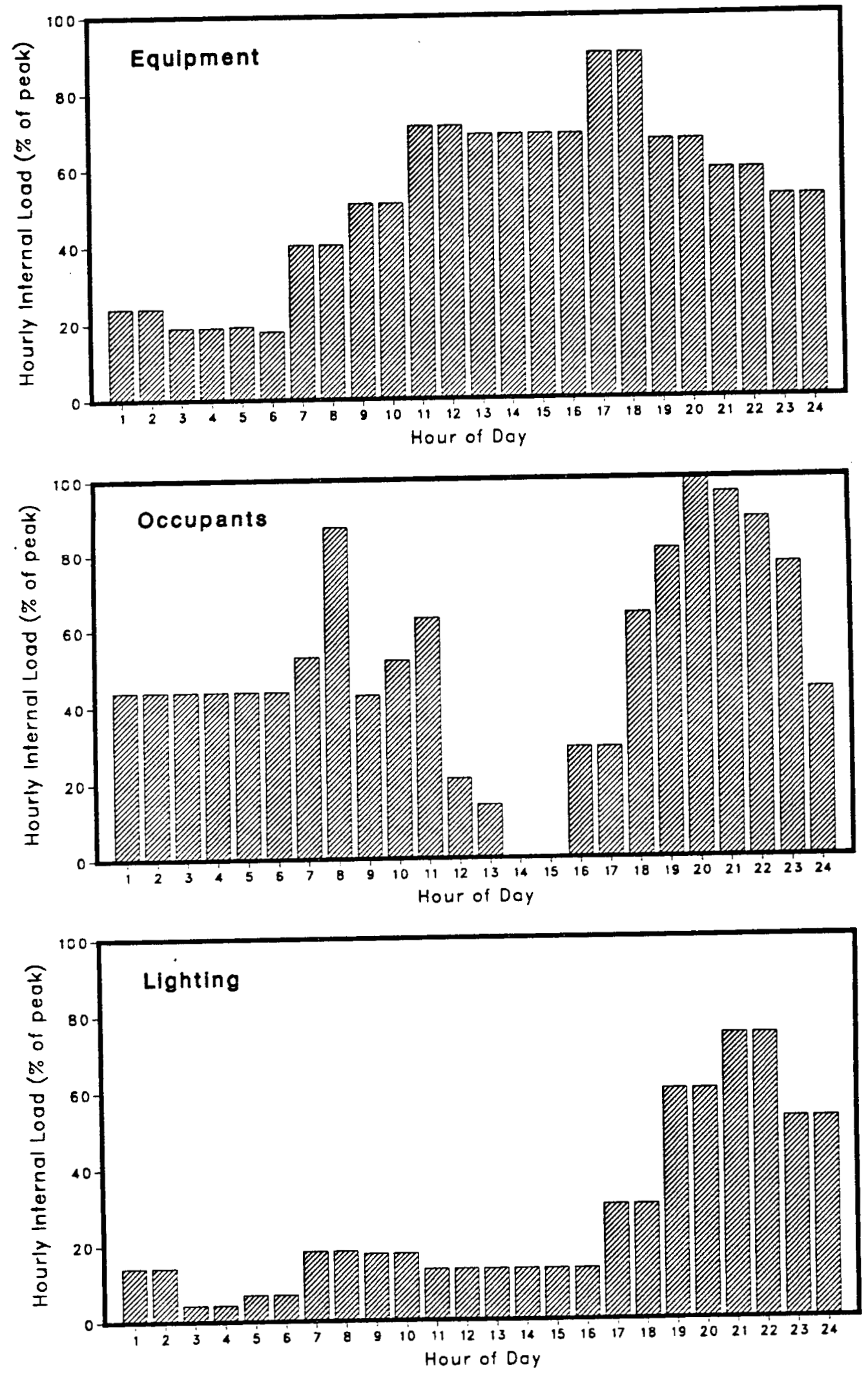
Table 8. Annual Appliance and Lighting Energy Use

\begin{tabular}{|c|c|c|c|c|c|c|}
\hline Appliance & Units & $\begin{array}{l}\text { Stock } \\
\text { Usage }\end{array}$ & $\begin{array}{l}\text { 1990s } \\
\text { Usage }\end{array}$ & $\begin{array}{l}\text { Percent to } \\
\text { Conditioned }\end{array}$ & $\begin{array}{c}\text { Percent to } \\
\text { Unconditioned }\end{array}$ & $\begin{array}{l}\text { Percent } \\
\text { Latent }\end{array}$ \\
\hline \multicolumn{7}{|l|}{ Refrigerators } \\
\hline New & $\mathrm{kWh}$ & 1125 & 705 & 100 & 0 & 0 \\
\hline Old & $\mathrm{kWh}$ & 1600 & 1600 & 15 & 85 & 0 \\
\hline Electric Range & kWh & 1200 & 1010 & 100 & 0 & 35 \\
\hline Gas Range & MMBtu & 9 & 5 & 100 & 0 & 35 \\
\hline Dishwasher & $\mathrm{kWh}$ & 200 & 160 & 0 & 0 & 0 \\
\hline Clothes Washer & $\mathrm{kWh}$ & 110 & 95 & 0 & 0 & 0 \\
\hline Clothes Dryer & $\mathrm{kWh}$ & 900 & 750 & 10 & 0 & 0 \\
\hline Freezer & kWh & 950 & 475 & 50 & 50 & 0 \\
\hline B/W Television & $\mathrm{kWh}$ & 100 & 100 & 100 & 0 & 0 \\
\hline Color Television & kWh & 320 & 320 & 100 & 0 & 0 \\
\hline Small Appliances & kWh & 300 & 300 & 100 & 0 & 0 \\
\hline \multicolumn{7}{|l|}{ Water Heat $\dagger$} \\
\hline Standby & $\mathrm{kWh}$ & 1320 & 1320 & 50 & 50 & 0 \\
\hline Use & $\mathrm{kWh}$ & 2800 & 2800 & 10 & 0 & 33 \\
\hline Lighting & $\mathrm{kWh} / \mathrm{ft}^{2}$ & 1 & 1 & 90 & 0 & 0 \\
\hline
\end{tabular}

† Water heat energy use for internal gains calculation only.

\section{Non-HVAC Loads Methodology}

We calculated average annual non-HVAC electricity consumption per building using the same method for calculating intemal gains, by combining typical appliance and lighting energy usage with the appliance saturations for each census division derived from the 1987 RECS data tape. Electric dryers were assumed since they are predominate in all census divisions. Electric cooking was assumed in all areas except for the West South Central census division. The resulting values are shown in Table 9. The non-HVAC electric value includes all electricity used by the household, including that which would occur outside the conditioned space.

\section{Domestic Hot Water Loads Methodology}

Energy use for heating water is a function of several variables such as water storage temperature, inlet and outlet temperatures, air temperatures, and the rate of usage of hot water. In addition, hot water consumption is highly dependent on behavior and is often influenced by cultural and social norms. Obviously, not all of these variables can be incorporated into the estimates of weekly energy consumption for heating water. To calculate the annual hot water load, we used the methodology developed for the California Residential Building Energy Efficiency Standards, ${ }^{35}$ which is mathematically identical to the DOE calculations: ${ }^{36}$

One of the most uncertain parameters in the estimation of hot water loads in any building type is the average per capita water usage. For example, average measured water consumption reported in the literature varies between types of dwellings (single-family, multifamily, etc.), 
Table 9. Estimated Average Annual Internal Loads per Building

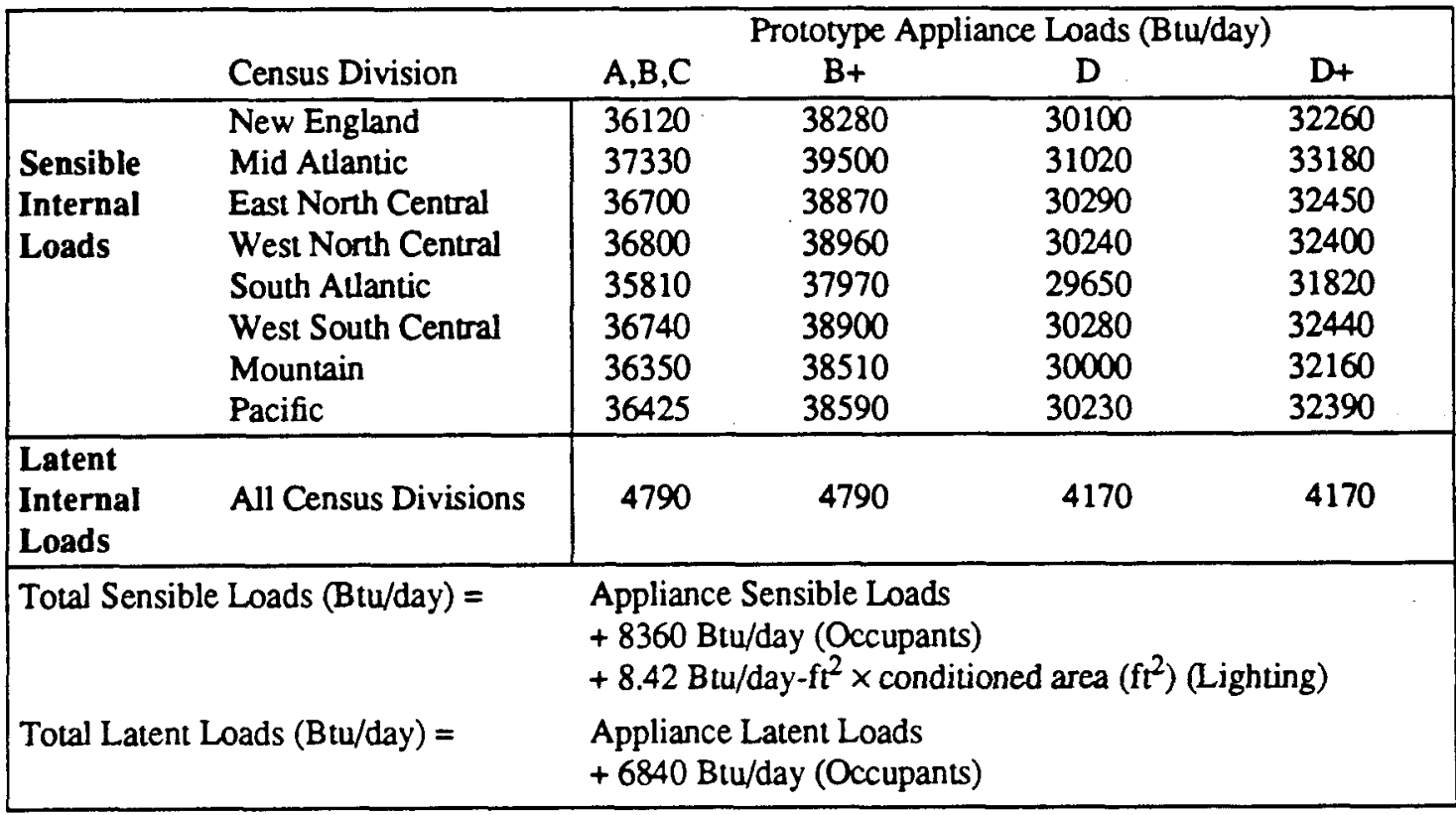

$$
\text { Load }=W \times C_{p} \times\left(T_{T}-T_{M}\right) \times 365 \text { days }
$$

where $\mathrm{W}=$ average daily hot water consumption ( 62.4 gallons) ${ }^{36}$ (based on 3 occupants)

$\mathrm{C}_{\mathrm{p}}=\quad$ energy required per gallon heated $\left(8.25 \mathrm{Btu} / \mathrm{gal} /{ }^{\circ} \mathrm{F}\right)$

$\mathrm{T}_{\mathrm{T}}=$ tank set temperature $\left(140^{\circ} \mathrm{F}\right)$

$\mathrm{T}_{\mathrm{M}}=\quad$ city water main temperature (estimated by well temperatures)

geographic regions, and time of year. Standard values include the DOE standard assumption for single-family residences, which is about $21.4 \mathrm{gal} /$ person-day (64.2 gal/household-day) and assumes the presence of a clothes washer in each residence, and the ASHRAE standard value of 62.4 gal/household-day. ${ }^{37}$ A recent survey for ASHRAE of available field-measured hot water usage data showed the ASHRAE standard assumption to be valid as an average national value. $^{38}$

This survey also showed significant variation in hot water use between climatic locations and between seasons in each location. Thus, we added both geographical and seasonal variations in consumption levels as a function of outdoor temperatures based on a relationship developed in a study of apartments in New Jersey ${ }^{39}$ and modified for use in the previous database project for multifamily buildings. ${ }^{7}$ The method is used to calculate both annual average hot water use for each location and monthly hot water use within each location:

The domestic water heating loads are further apportioned by hour using data and hourly water use profiles from other studies. ${ }^{11,39,40,41}$ The estimated domestic hot water load reflects only the amount of heat necessary to raise the temperature of the water from the main to the 


$$
\begin{aligned}
& W^{\prime}=W+\left(55-T_{A}\right) \times\left[0.155\left(\text { gal/person-day- }{ }^{\circ} F\right) \times 3(\text { persons/household })\right] \\
& \text { where } \mathbf{W}^{\prime}=\text { daily hot water consumption (gallons) } \\
& W=\text { national average daily hot water consumption ( } 62.4 \text { gallons })^{36} \\
& 55=\text { national average air temperature }\left({ }^{\circ} \mathrm{F}\right) \\
& \mathrm{T}_{\mathrm{A}}=\text { air temperature for each base city }\left({ }^{\circ} \mathrm{F}\right)
\end{aligned}
$$

tank temperature of $140^{\circ} \mathrm{F}$. The effects of bumer efficiency and standby losses are not considered in the calculation of water heating loads, but standby losses are included in the internal loads assumptions (see Table 8). Since the average well temperature in most cities corresponds to the average air temperature, we use data from the weather tapes to estimate city water main temperature $\left(T_{M}\right)$. Table 10 shows the average air and well temperatures for the base cities in this analysis. It also shows the average annual daily hot water use calculated for each base city used in calculating the water heating loads. We provide the average daily and monthly water heating loads in Appendix C.

Table 10. Average Air and Well Temperature and Hot Water Use for Base Cities

\begin{tabular}{|lccc|lccc|}
\hline & $\begin{array}{c}\text { Annual } \\
\text { Average } \\
\text { Air Temp. } \\
\text { City }\end{array}$ & $\begin{array}{c}\text { Well } \\
\text { (F) }\end{array}$ & $\begin{array}{c}\text { Annual } \\
\text { Average } \\
\text { Hot Water Use } \\
\text { (Gal/Day) }\end{array}$ & City & $\begin{array}{r}\text { Annual } \\
\text { Average } \\
\text { Air Temp. } \\
\text { (F) }\end{array}$ & $\begin{array}{c}\text { Well } \\
\text { Temp. } \\
\text { (F) }\end{array}$ & $\begin{array}{c}\text { Annual } \\
\text { Average } \\
\text { Hater Use } \\
\text { (Gal/Day) }\end{array}$ \\
\hline Albuquerque & 56.6 & 62.0 & 61.6 & Los Angeles & 61.0 & 62.0 & 59.6 \\
Atlanta & 60.6 & 64.0 & 59.8 & Miami & 75.2 & 77.0 & 52.9 \\
Boston & 51.0 & 48.0 & 64.3 & Minneapolis & 45.1 & 45.0 & 67.1 \\
Chicago & 50.7 & 51.0 & 64.4 & New Orleans & 68.0 & 70.0 & 56.3 \\
Denver & 50.1 & 47.0 & 64.7 & Phoenix & 71.5 & 66.0 & 54.6 \\
Fort Worth & 65.1 & 68.0 & 57.6 & San Francisco & 55.4 & 58.0 & 62.2 \\
New York & 54.2 & 52.0 & 62.8 & Seattle & 50.5 & 52.0 & 64.5 \\
Kansas City & 56.1 & 54.0 & 61.9 & Washington & 57.1 & 54.0 & 61.4 \\
\hline
\end{tabular}




\section{4}

\section{RESULTS}

In this section we present the heating and cooling loads derived from the DOE-2 simulations as well as the non-HVAC electricity and gas usage for the range of prototypical houses representing pre-1940s to 1990s construction practices. The results and discussion are organized by end-use. First, the heating loads are presented according to several end-uses: total annual space heating loads, peak loads, load intensities (i.e., per square foot), and water heating loads. We next cover the annual cooling loads as total space cooling, latent, peak, and load intensities. The other building energy requirements for gas and electric appliances (i.e., nonHVAC) are presented and discussed separately. These non-HVAC loads were estimated by engineering calculations as described in the Methods section. Next, we briefly describe the total annual loads for space heating and cooling on a square foot basis according to the highest and lowest overall users. Finally, we provide a brief comparison of the loads data base to surveyed data from several sources.

\section{HEATING LOADS}

The heating loads estimated in this study are used for space heating and hot water systems. The space heating was based on outdoor temperatures on an hourly basis throughout the year, the assumed temperature settings, house size, and thermal integrity (i.e., level of insulation). For this study, we assumed a heating thermostat setting of $70^{\circ} \mathrm{F}$ with an eight-hour nighttime setback of $6^{\circ} \mathrm{F}$. The total annual heating loads would be higher without the thermostat setbacks, but we assumed that these conditions represent the current "average" conditions in single-family buildings. The heating load for domestic hot water systems varied in this study according to the assumed input water temperature and on hot water usage patterns, which in turn, were based on the average air temperature. The other variable (e.g., number of occupants) was held constant in each prototypical house. In reality, these assumptions are good for populations of houses, but they may not be realistic on an individual house basis.

\section{Space Heating}

\section{Annual Loads}

In Figure 4 (and Table 11) the annual space heating loads (as MMBtu†) are shown for each prototypical house at each location. As shown in Figure 4, the B1+ house, which represents the 1950-70 prototype with thermal upgrades and with greater floor area than the B1

$\overline{\dagger M B B u}=10^{6}$ Btu 
Figure 4. Annual Heatlng Loads for SIngle Family Prototypes

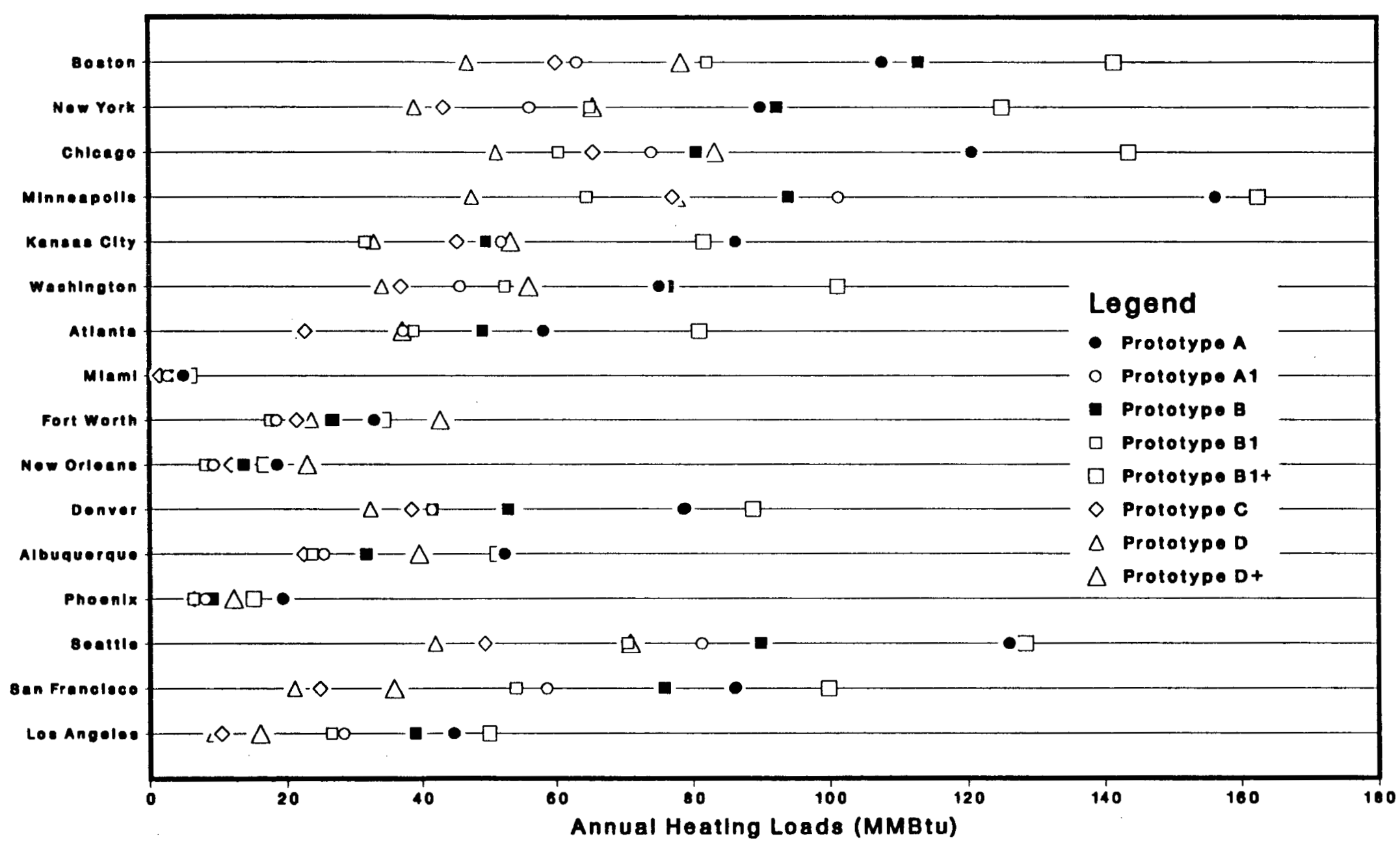


Table 11. Total Building Loads for Single-family Prototypes

\begin{tabular}{|c|c|c|c|c|c|c|c|}
\hline & & & Total & Latent & & Non- & IVAC \\
\hline REGION/City & $\begin{array}{l}\text { Proto- } \\
\text { type }\end{array}$ & $\begin{array}{l}\text { Heating } \\
\text { Load } \\
\text { (MMBtu) }\end{array}$ & $\begin{array}{l}\text { Cooling } \\
\text { Load } \\
\text { (MMBtu) }\end{array}$ & $\begin{array}{l}\text { Cooling } \\
\text { Load } \\
\text { (MMBtu) }\end{array}$ & $\begin{array}{c}\text { Water } \\
\text { Load } \\
\text { (MMBtu) }\end{array}$ & $\begin{array}{c}\text { Electric } \\
\text { Load } \\
(\mathbf{k W h})\end{array}$ & $\begin{array}{c}\text { Gas } \\
\text { Load } \\
\text { (MMBtu) }\end{array}$ \\
\hline NORTHEAST & & & & & & & \\
\hline & $\mathbf{A}$ & 107.8 & 10.0 & 1.7 & 17.8 & 6248 & 0.0 \\
\hline Boston & $A 1$ & 63.2 & 8.2 & 1.6 & 17.8 & 6248 & 0.0 \\
\hline & B & 113.1 & 11.5 & 2.0 & 17.8 & 7029 & 0.0 \\
\hline & B1 & 82.2 & 10.9 & 1.8 & 17.8 & 7029 & 0.0 \\
\hline & B1+ & 141.6 & 17.8 & 2.9 & 17.8 & 9273 & 0.0 \\
\hline & C & 60.1 & 6.7 & 1.3 & 17.8 & 6898 & 0.0 \\
\hline & $\mathrm{D}$ & 46.8 & 7.7 & 1.4 & 17.8 & 6142 & 0.0 \\
\hline & Dt & 78.4 & 11.8 & 2.1 & 17.8 & 8243 & 0.0 \\
\hline & $\bar{A}$ & 90.0 & 12.2 & 2.2 & 16.6 & 6486 & 0.0 \\
\hline New York & A1 & 56.3 & 10.2 & 2.0 & 16.6 & 6486 & 0.0 \\
\hline & B & 92.4 & 13.1 & 2.3 & 16.6 & 7041 & 0.0 \\
\hline & $\mathrm{Bl}$ & 65.1 & 12.1 & 2.1 & 16.6 & 7041 & 0.0 \\
\hline & $\mathrm{Bl}+$ & 125.2 & 21.0 & 3.5 & 16.6 & 9507 & 0.0 \\
\hline & $\mathrm{C}$ & 43.4 & 9.2 & 1.8 & 16.6 & 7168 & 0.0 \\
\hline & D & 39.0 & 8.7 & 1.8 & 16.6 & 6346 & 0.0 \\
\hline & $\mathrm{D}+$ & 65.5 & 12.8 & 2.5 & 16.6 & 8448 & 0.0 \\
\hline NORTH CEN & & & & & & & \\
\hline & A & 120.8 & 15.6 & 2.9 & 17.3 & 6466 & 0.0 \\
\hline Chicago & Al & 74.0 & 12.7 & 2.7 & 17.3 & 6466 & 0.0 \\
\hline & $\mathrm{B}$ & 80.6 & 7.6 & 1.8 & 17.3 & 6270 & 0.0 \\
\hline & B1 & 60.5 & 6.8 & 1.6 & 17.3 & 6270 & 0.0 \\
\hline & $\mathrm{Bl}+$ & 143.7 & 12.1 & 2.7 & 17.3 & 8641 & 0.0 \\
\hline & $\mathrm{C}$ & 65.5 & 10.1 & 2.2 & 17.3 & 7110 & 0.0 \\
\hline & $\mathrm{D}$ & 51.4 & 11.8 & 2.5 & 17.3 & 6291 & 0.0 \\
\hline & $\mathrm{D}+$ & 83.3 & 17.5 & 3.6 & 17.3 & 8392 & 0.0 \\
\hline & $\bar{A}$ & 156.4 & 13.2 & 2.2 & 19.2 & 6522 & 0.0 \\
\hline Minneapolis & Al & 101.4 & 11.4 & 2.4 & 19.2 & 6522 & 0.0 \\
\hline & B & 94.1 & 6.3 & 1.3 & 19.2 & 6046 & 0.0 \\
\hline & $\mathrm{B} 1$ & 64.6 & 5.1 & 1.2 & 19.2 & 6046 & 0.0 \\
\hline & $\mathrm{B} 1+$ & 162.6 & 9.2 & 2.0 & 19.2 & 8250 & 0.0 \\
\hline & $C$ & 77.1 & 6.9 & 1.5 & 19.2 & 7166 & 0.0 \\
\hline & $\mathrm{D}$ & 47.5 & 7.9 & 1.5 & 19.2 & 6306 & 0.0 \\
\hline & $\mathrm{D}+$ & 77.7 & 11.5 & 2.1 & 19.2 & 8407 & 0.0 \\
\hline & $A$ & 86.3 & 28.2 & 5.0 & 16.0 & 6522 & 0.0 \\
\hline Kansas City & Al & 52.2 & 22.9 & 4.6 & 16.0 & 6522 & 0.0 \\
\hline & B & 49.7 & 14.2 & 2.8 & 16.0 & 6046 & 0.0 \\
\hline & Bl & 31.7 & 11.6 & 2.5 & 16.0 & 6046 & 0.0 \\
\hline & Blt & 81.7 & 21.8 & 4.6 & 16.0 & 8250 & 0.0 \\
\hline & $c$ & 45.3 & 18.9 & 3.8 & 16.0 & 7166 & 0.0 \\
\hline & D & 33.0 & 20.9 & 4.1 & 16.0 & 6306 & 0.0 \\
\hline & $\mathrm{D}+$ & 53.6 & 31.4 & 6.1 & 16.0 & 8407 & 0.0 \\
\hline
\end{tabular}


Table 11. Total Building Loads for Single-family Prototypes (cont.)

\begin{tabular}{|c|c|c|c|c|c|c|c|}
\hline REGION/City & $\begin{array}{l}\text { Proto- } \\
\text { type }\end{array}$ & $\begin{array}{l}\text { Heating } \\
\text { Load } \\
\text { (MMBtu) }\end{array}$ & $\begin{array}{c}\text { Total } \\
\text { Cooling } \\
\text { Load } \\
\text { (MMBtu) }\end{array}$ & $\begin{array}{l}\text { Latent } \\
\text { Cooling } \\
\text { Load } \\
\text { (MMBu) }\end{array}$ & $\begin{array}{c}\text { Hot } \\
\text { Water } \\
\text { Load } \\
\text { (MMBw) }\end{array}$ & $\begin{array}{l}\text { Non } \\
\text { Electric } \\
\text { Load } \\
(\mathrm{kWh})\end{array}$ & $\begin{array}{l}\text { VAC } \\
\text { Gas } \\
\text { Load } \\
\text { (MMBtu) }\end{array}$ \\
\hline \multicolumn{8}{|l|}{ SOUTH } \\
\hline & A & 75.1 & 20.6 & 4.4 & 15.9 & 5696 & 0.0 \\
\hline \multirow{8}{*}{ Washington } & Al & 45.7 & 16.0 & 3.2 & 15.9 & 5696 & 0.0 \\
\hline & B & 76.4 & 20.9 & 3.7 & 15.9 & 5949 & 0.0 \\
\hline & B1 & 52.7 & 19.1 & 3.4 & 15.9 & 5949 & 0.0 \\
\hline & $\mathrm{B} 1+$ & 101.3 & 33.2 & 5.8 & 15.9 & 7909 & 0.0 \\
\hline & $\mathrm{C}$ & 37.0 & 16.0 & 3.2 & 15.9 & 6714 & 0.0 \\
\hline & $\mathrm{D}$ & 34.2 & 15.7 & 3.2 & 15.9 & 5973 & 0.0 \\
\hline & $\mathrm{D}_{+}$ & 56.1 & 23.5 & 4.7 & 15.9 & 8075 & 0.0 \\
\hline & $\bar{A}$ & 58.2 & 20.1 & 3.6 & 13.7 & 5696 & 0.0 \\
\hline \multirow[t]{8}{*}{ Atlanta } & Al & 37.3 & 13.9 & 2.9 & 13.7 & 5696 & 0.0 \\
\hline & B & 49.1 & 15.0 & 3.0 & 13.7 & 5949 & 0.0 \\
\hline & $\mathrm{B} 1$ & 38.9 & 13.7 & 2.8 & 13.7 & 5949 & 0.0 \\
\hline & $\mathrm{Bl+}$ & 81.0 & 22.9 & 4.4 & 13.7 & 7909 & 0.0 \\
\hline & $\mathrm{C}$ & 22.8 & 17.4 & 3.5 & 13.7 & 6714 & 0.0 \\
\hline & $\mathrm{D}$ & 22.5 & 17.4 & 3.5 & 13.7 & 5973 & 0.0 \\
\hline & D+ & 37.2 & 25.8 & 5.1 & 13.7 & 8075 & 0.0 \\
\hline & $\bar{A}$ & 5.0 & 50.1 & 12.8 & 10.0 & 5696 & 0.0 \\
\hline \multirow[t]{8}{*}{ Miami } & Al & 2.7 & 40.9 & 12.5 & 10.0 & 5696 & 0.0 \\
\hline & B & 3.5 & 45.8 & 13.4 & 10.0 & 5949 & 0.0 \\
\hline & B1 & 2.6 & 41.9 & 12.0 & 10.0 & 5949 & 0.0 \\
\hline & B1+ & 5.9 & 70.9 & 20.4 & 10.0 & 7909 & 0.0 \\
\hline & $\mathrm{C}$ & 1.6 & 35.1 & 10.3 & 10.0 & 6154 & 0.0 \\
\hline & $\mathrm{D}$ & 1.6 & 35.2 & 10.6 & 10.0 & 5413 & 0.0 \\
\hline & $\mathrm{D}+$ & 3.0 & 53.1 & 16.0 & 10.0 & 7315 & 0.0 \\
\hline & $\mathrm{A}$ & 33.0 & 28.5 & 6.1 & 12.5 & 4617 & 9.0 \\
\hline \multirow[t]{8}{*}{ Fort Worth } & Al & 18.5 & 22.3 & 5.5 & 12.5 & 4617 & 9.0 \\
\hline & B & 26.7 & 26.4 & 6.2 & 12.5 & 4955 & 9.0 \\
\hline & $\mathrm{B} 1$ & 17.6 & 23.3 & 5.7 & 12.5 & 4955 & 9.0 \\
\hline & $\mathrm{Blt}$ & 34.4 & 37.5 & 9.1 & 12.5 & 6736 & 9.0 \\
\hline & $\mathrm{C}$ & 21.5 & 20.8 & 5.0 & 12.5 & 5187 & 9.0 \\
\hline & $\mathrm{D}$ & 23.7 & 21.1 & 5.1 & 12.5 & 4556 & 4.9 \\
\hline & D+ & 42.8 & 32.6 & 7.8 & 12.5 & 6457 & 4.9 \\
\hline & $\bar{A}$ & 18.6 & 26.1 & 6.6 & 11.9 & 4617 & 9.0 \\
\hline \multirow{7}{*}{ New Orleans } & Al & 9.3 & 20.5 & 6.0 & 11.9 & 4617 & 9.0 \\
\hline & B & 13.7 & 23.6 & 6.6 & 11.9 & 4955 & 9.0 \\
\hline & B1 & 8.2 & 21.3 & 6.3 & 11.9 & 4955 & 9.0 \\
\hline & $\mathrm{B} 1+$ & 16.8 & 33.3 & 9.9 & 11.9 & 6736 & 9.0 \\
\hline & $\mathrm{C}$ & 11.9 & 18.6 & 5.4 & 11.9 & 5187 & 9.0 \\
\hline & $\mathrm{D}$ & 12.5 & 17.7 & 5.3 & 11.9 & 4556 & 4.9 \\
\hline & Dt & 23.1 & 26.2 & 7.8 & 11.9 & 6457 & 4.9 \\
\hline
\end{tabular}


Table 11. Total Building Loads for Single-family Prototypes (cont.)

\begin{tabular}{|c|c|c|c|c|c|c|c|}
\hline \multirow[b]{2}{*}{ REGION/City } & \multirow[b]{2}{*}{$\begin{array}{l}\text { Proto- } \\
\text { type }\end{array}$} & \multirow[b]{2}{*}{$\begin{array}{c}\text { Heating } \\
\text { Load } \\
\text { (MMBtu) }\end{array}$} & \multirow{2}{*}{$\begin{array}{l}\text { Total } \\
\text { Cooling } \\
\text { Load } \\
\text { (MMBtu) }\end{array}$} & \multirow{2}{*}{$\begin{array}{c}\text { Latent } \\
\text { Cooling } \\
\text { Load } \\
\text { (MMBtu) } \\
\end{array}$} & \multirow{2}{*}{$\begin{array}{c}\text { Hot } \\
\text { Water } \\
\text { Load } \\
\text { (MMBtu) }\end{array}$} & \multicolumn{2}{|c|}{ Non-HVAC } \\
\hline & & & & & & $\begin{array}{c}\text { Electric } \\
\text { Load } \\
(\mathrm{kWh}) \\
\end{array}$ & $\begin{array}{c}\text { Gas } \\
\text { Load } \\
\text { (MMBw) } \\
\end{array}$ \\
\hline \multicolumn{8}{|l|}{ WEST } \\
\hline & A & 78.6 & 9.1 & 0.1 & 18.1 & 5738 & 0.0 \\
\hline \multirow[t]{8}{*}{ Denver } & Al & 41.5 & 4.9 & 0.1 & 18.1 & 5738 & 0.0 \\
\hline & B & 53.1 & 3.5 & 0.0 & 18.1 & 5839 & 0.0 \\
\hline & B1 & 41.6 & 3.5 & 0.0 & 18.1 & 5839 & 0.0 \\
\hline & B1t & 88.8 & 6.0 & 0.0 & 18.1 & 7652 & 0.0 \\
\hline & $\mathrm{C}$ & 38.5 & 8.1 & 0.1 & 18.1 & 6829 & 0.0 \\
\hline & D & 32.4 & 7.8 & 0.1 & 18.1 & 6034 & 0.0 \\
\hline & D+ & 53.3 & 12.1 & 0.1 & 18.1 & 8135 & 0.0 \\
\hline & $\bar{A}$ & 52.6 & 15.9 & 0.3 & 14.5 & 5738 & 0.0 \\
\hline \multirow[t]{8}{*}{ Albuquerque } & $\mathrm{Al}$ & 25.5 & 9.3 & 0.3 & 14.5 & 5738 & 0.0 \\
\hline & B & 31.8 & 8.2 & 0.3 & 14.5 & 5839 & 0.0 \\
\hline & Bl & 23.8 & 8.1 & 0.3 & 14.5 & 5839 & 0.0 \\
\hline & $\mathrm{Bl}+$ & 51.3 & 14.2 & 0.3 & 14.5 & 7652 & 0.0 \\
\hline & $\mathrm{C}$ & 22.5 & 6.5 & 0.2 & 14.5 & 6419 & 0.0 \\
\hline & $\mathrm{D}$ & 22.5 & 6.1 & 0.2 & 14.5 & 5624 & 0.0 \\
\hline & $\mathrm{D}+$ & 39.6 & 8.8 & 0.2 & 14.5 & 7525 & 0.0 \\
\hline & $\bar{A}$ & 19.4 & 47.3 & 2.8 & 12.2 & 5738 & 0.0 \\
\hline \multirow[t]{8}{*}{ Phoenix } & $\mathrm{Al}$ & 8.1 & 32.0 & 2.6 & 12.2 & 5738 & 0.0 \\
\hline & B & 9.1 & 32.7 & 2.7 & 12.2 & 5839 & 0.0 \\
\hline & Bl & 6.4 & 30.3 & 2.5 & 12.2 & 5839 & 0.0 \\
\hline & $\mathrm{Bl+}$ & 15.1 & 54.8 & 3.9 & 12.2 & 7652 & 0.0 \\
\hline & C & 6.5 & 30.2 & 2.6 & 12.2 & 6419 & 0.0 \\
\hline & D & 6.6 & 30.0 & 2.6 & 12.2 & 5624 & 0.0 \\
\hline & $\mathrm{D}+$ & 12.2 & 46.3 & 3.7 & 12.2 & 7525 & 0.0 \\
\hline & $\bar{A}$ & 126.0 & 3.0 & 0.2 & 17.1 & 6187 & 0.0 \\
\hline \multirow[t]{8}{*}{ Seaule } & Al & 81.2 & 1.7 & 0.1 & 17.1 & 6187 & 0.0 \\
\hline & $\mathrm{B}$ & 89.9 & 1.7 & 0.1 & 17.1 & 6176 & 0.0 \\
\hline & B1 & 70.4 & 1.5 & 0.1 & 17.1 & 6176 & 0.0 \\
\hline & $\mathrm{B} 1+$ & 128.4 & 2.3 & 0.2 & 17.1 & 7795 & 0.0 \\
\hline & $C$ & 49.4 & 3.9 & 0.2 & 17.1 & 6854 & 0.0 \\
\hline & $\mathrm{D}$ & 42.0 & 3.8 & 0.2 & 17.1 & 6096 & 0.0 \\
\hline & $\mathrm{D}+$ & 70.8 & 6.1 & 0.3 & 17.1 & 8197 & 0.0 \\
\hline & A & 86.0 & 1.6 & 0.0 & 15.4 & 6187 & 0.0 \\
\hline \multirow[t]{8}{*}{ San Francisco } & Al & 58.6 & 0.9 & 0.0 & 15.4 & 6187 & 0.0 \\
\hline & B & 75.7 & 1.0 & 0.0 & 15.4 & 6176 & 0.0 \\
\hline & B1 & 54.2 & 0.8 & 0.0 & 15.4 & 6176 & 0.0 \\
\hline & $\mathrm{B} 1+$ & 99.8 & 1.3 & 0.0 & 15.4 & 7795 & 0.0 \\
\hline & $\mathrm{C}$ & 24.9 & 1.1 & 0.0 & 15.4 & 6854 & 0.0 \\
\hline & $D$ & 21.1 & 1.2 & 0.0 & 15.4 & 6096 & 0.0 \\
\hline & $D+$ & 35.9 & 2.0 & 0.0 & 15.4 & 8197 & 0.0 \\
\hline & $\mathrm{A}$ & 44.7 & 4.5 & 0.6 & 14.0 & 6187 & 0.0 \\
\hline \multirow[t]{7}{*}{ Los Angeles } & $\mathrm{Al}$ & 28.4 & 2.3 & 0.3 & 14.0 & 6187 & 0.0 \\
\hline & B & 39.0 & 2.5 & 0.3 & 14.0 & 6176 & 0.0 \\
\hline & B1 & 26.6 & 2.1 & 0.2 & 14.0 & 6176 & 0.0 \\
\hline & Bl+ & 50.1 & 3.3 & 0.3 & 14.0 & 7795 & 0.0 \\
\hline & C & 10.4 & 3.2 & 0.4 & 14.0 & 6854 & 0.0 \\
\hline & $\mathrm{D}$ & 9.3 & 3.0 & 0.3 & 14.0 & 6096 & 0.0 \\
\hline & D+ & 16.0 & 5.0 & 0.5 & 14.0 & 8197 & 0.0 \\
\hline
\end{tabular}


house, had the highest space beating loads in all climates except the West South Central region (Fort Worth and New Orleans). The location with the highest annual heating load was Minneapolis (162.6 MMBtu). Annual heating was also high in other cold climates, e.g., Chicago (143.7 MMBtu), and Boston (141.6 MMBtu). In Fort Worth and New Orleans, the D+ house was $20 \%$ and $27 \%$ higher than the B1+ house, respectively (see Fig. 4 and Table 11). The annual beating loads (42.8 MMBtu in Fort Worth and 23.1 MMBtu in New Orleans), however, were significantly less than those in the colder climates because of higher internal heat gains assumed in the west south central census region.

The next highest space heating loads are found in the A house (pre-1940s) in most locations. The annual usage is significant in some locations, e.g., Minneapolis (156.4 MMBtu), Seattle (126.0 MMBtu), and Chicago (120.8 MMBtu). In Kansas City, the A house had a slightly higher annual space heating load than the B1+ house (86.3 MMBtu vs. 81.7 MMBtu). This same situation was found in Phoenix where heating loads are generally small. The $A$ house in Phoenix required 19.4 MMBtu/yr vs. 15.1 MMBtu/yr for the B1+ house.

The lowest annual space heating loads in all but three locations (Kansas City, Fort Worth, and New Orleans) were found in the D house (1990s construction practices). The annual loads for the D house ranged from 1.6 MMBtu in Miami to 51.4 MMBtu in Chicago. The annual space heating load in the B1 house in Kansas City was $4 \%$ less than that of the D house. The reason for this difference is that the $\mathrm{D}$ house is about twice as large and has two-storied rather than single-storied construction. The B1 house was also more efficient than the 1990 s house in Fort Worth and New Orleans where the retrofitted 1950-70s house required $26 \%$ and $34 \%$ less load, respectively. In each case it was demonstrated that even though the $D$ house had higher thermal integrity than the B1 house, the effects of house size were more important.

\section{Annual Peak Heating Lasds}

In most cases the highest peak heating loads were found in the $\mathrm{B} 1+$ prototypical house (see Table 12). For example, the simulated peak requirements were high in Boston (102.2 kBtu), Washington D.C. (94.1 kBtu), and Chicago (91.1 kBtu). The heating peak loads in the A house were also high as shown in Minneapolis ( $85.5 \mathrm{kBtu})$ and Kansas City (66 kBtu). In Fort Worth and New Orleans the larger $D$ house $(D+)$ showed relatively high heating peaks (53.1 kBtu in Fort Worth and $45.5 \mathrm{kBtu}$ in New Orleans).

At the other extreme, the lowest heating peaks in the colder climates were found in several prototypical bouses depending on the specific location. In the majority of cases, the D house had the lowest heating peak, e.g., New York (32.6 kBtu) and Minneapolis (34.2 kBtu). The B1 house also had small peak heating loads in some climates (38.4 kBtu in Denver and $40.0 \mathrm{kBtu}$ in Chicago). As expected the peak beating loads were smaller in climates with shorter heating seasons, such as Phoenix (27.0 kBtu) and Fort Worth (23.5 kBtu), and Miami (19.7 kBtu). 
Table 12. Peak Building Loads for Single-family Prototypes

\begin{tabular}{|c|c|c|c|c|c|c|c|c|}
\hline REGION/City & $\begin{array}{l}\text { Proto- } \\
\text { type }\end{array}$ & $\begin{array}{c}\text { Peak H } \\
\text { Load } \\
(\mathrm{kBtu} / \mathrm{hr})\end{array}$ & $\begin{array}{l}\text { ating } \\
\text { Temp } \\
\left({ }^{\circ} \mathrm{F}\right)\end{array}$ & $\begin{array}{c}\text { Load } \\
(\mathrm{kBtu} / \mathrm{hr})\end{array}$ & $\begin{array}{l}\text { Peak To } \\
\text { Temp* } \\
\left({ }^{\circ} \mathrm{F}\right)\end{array}$ & $\begin{array}{l}\text { al Coolin } \\
\text { HR } \\
\left(\times 10^{4}\right)\end{array}$ & $\underset{(\mathrm{kBtu} / \mathrm{hr})}{\text { Lint Load }}$ & $\begin{array}{l}\text { Peak Latent } \\
\text { Cooling Load } \\
\text { (kBtu/hr) }\end{array}$ \\
\hline \multicolumn{9}{|l|}{ NORTHEAST } \\
\hline & $\mathbf{A}$ & 70.1 & -3 & 35.1 & 97 & 128 & 8.0 & 8.8 \\
\hline \multirow{8}{*}{ Boston } & A1 & 47.6 & -3 & 27.5 & 97 & 128 & 6.4 & 7.5 \\
\hline & B & 77.0 & -3 & 41.0 & 97 & 128 & 9.4 & 10.3 \\
\hline & B1 & 60.4 & -3 & 36.4 & 97 & 128 & 8.3 & 9.1 \\
\hline & B1+ & 102.2 & -3 & 61.6 & 97 & 128 & 14.3 & 15.5 \\
\hline & C & 42.8 & -3 & 25.5 & 97 & 128 & 5.9 & 6.9 \\
\hline & $\mathbf{D}$ & 40.1 & -3 & 25.9 & 97 & 128 & 6.5 & 7.0 \\
\hline & Dt & 65.3 & -3 & 41.8 & 97 & 128 & 10.6 & 11.4 \\
\hline & A & 55.6 & 9 & 28.5 & 95 & 132 & 5.5 & 7.1 \\
\hline \multirow[t]{7}{*}{ New York } & $\mathbf{A 1}$ & 40.1 & 9 & 22.9 & 90 & 169 & 6.0 & 6.1 \\
\hline & $\mathbf{B}$ & 58.8 & 9 & 31.3 & 90 & 169 & 7.5 & 7.6 \\
\hline & B1 & 46.5 & 9 & 26.7 & 90 & 169 & 6.4 & 6.6 \\
\hline & B1+ & 85.6 & 9 & 49.2 & 90 & 169 & 12.3 & 12.7 \\
\hline & C & 34.2 & 9 & 20.2 & 90 & 169 & 5.4 & 5.7 \\
\hline & $\mathbf{D}$ & 32.6 & 9 & 19.4 & 90 & 169 & 5.4 & 5.6 \\
\hline & D+ & 52.4 & 9 & 31.0 & 90 & 169 & 8.8 & 9.1 \\
\hline \multicolumn{9}{|c|}{ NORTH CENTRAL } \\
\hline & A & 78.3 & -9 & 35.3 & 94 & 148 & 6.9 & 10.9 \\
\hline \multirow[t]{8}{*}{ Chicago } & A1 & 55.4 & -9 & 28.5 & 94 & 148 & 6.4 & 9.6 \\
\hline & B & 50.1 & -9 & 20.8 & 99 & 135 & 3.4 & 7.0 \\
\hline & B1 & 40.0 & -9 & 18.3 & 91 & 139 & 4.1 & 6.1 \\
\hline & $\mathrm{B} 1+$ & 91.1 & -9 & 37.6 & 91 & 139 & 8.6 & 13.2 \\
\hline & $\mathrm{C}$ & 47.4 & -9 & 25.4 & 94 & 148 & 5.7 & 8.5 \\
\hline & D & 43.2 & -9 & 26.5 & 91 & 139 & 5.8 & 8.8 \\
\hline & $\mathrm{D}+$ & 70.3 & -9 & 41.4 & 91 & 139 & 9.0 & 14.0 \\
\hline & $\bar{A}$ & 85.5 & -28 & 36.9 & 91 & 168 & 9.9 & 9.9 \\
\hline \multirow[t]{8}{*}{ Minneapolis } & A1 & 60.4 & -28 & 32.7 & 91 & 168 & 9.9 & 9.9 \\
\hline & B & 49.2 & -28 & 21.0 & 91 & 168 & 6.1 & 6.1 \\
\hline & B1 & 35.8 & -28 & 18.0 & 91 & 168 & 5.4 & 5.4 \\
\hline & B1t+ & 83.9 & -28 & 39.5 & 91 & 168 & 12.1 & 12.1 \\
\hline & C & 46.0 & -28 & 24.9 & 91 & 168 & 8.1 & 8.1 \\
\hline & D & 34.2 & -28 & 23.2 & 91 & 168 & 6.8 & 6.8 \\
\hline & D+ & 54.0 & -28 & 36.3 & 91 & 168 & 10.7 & 10.7 \\
\hline & $\overline{\mathbf{A}}$ & 66.0 & -7 & 35.8 & 99 & 165 & 7.1 & 8.9 \\
\hline \multirow[t]{7}{*}{ Kansas City } & A1 & 46.1 & -7 & 27.9 & 96 & 180 & 6.4 & 7.8 \\
\hline & B & 38.1 & -7 & 18.8 & 99 & 165 & 3.9 & 4.9 \\
\hline & B1 & 27.4 & -7 & 14.8 & 92 & 180 & 3.8 & 4.2 \\
\hline & B1+ & 63.8 & -7 & 33.2 & 92 & 180 & 8.9 & 9.7 \\
\hline & C & 39.7 & -7 & 24.3 & 96 & 180 & 5.6 & 6.9 \\
\hline & D & 38.1 & -7 & 24.2 & 96 & 180 & 5.7 & 7.0 \\
\hline & D+ & 60.1 & -7 & 38.2 & 96 & 180 & 9.1 & 11.2 \\
\hline
\end{tabular}

- Peak temperature on day of peak load, timing of peak load may differ between prototype in the same location. + Humidity ntio at peak temperature.

₹ Latent portion of total load at peak load. 
Table 12. Peak Building Loads for Single-family Prototypes (cont.)

\begin{tabular}{|c|c|c|c|c|c|c|c|c|}
\hline & & Peak H & ting & & Peak To & Cooling & & Peak Latent \\
\hline REGION/City & $\begin{array}{l}\text { Proto- } \\
\text { type }\end{array}$ & $\begin{array}{c}\text { Load } \\
(\mathrm{kBtu} / \mathrm{hr})\end{array}$ & $\begin{array}{l}\text { Temp } \\
\left({ }^{\circ} \mathrm{F}\right)\end{array}$ & $\begin{array}{c}\text { Load } \\
(\mathrm{kBtu} / \mathrm{hr})\end{array}$ & $\begin{array}{c}\text { Temp* } \\
\left({ }^{\circ} \mathrm{F}\right)\end{array}$ & $\begin{array}{l}\text { HRt } \\
\left(\times 10^{4}\right)\end{array}$ & $\begin{array}{l}\text { Lint Load } \\
(\mathrm{kBtu} / \mathrm{hr})\end{array}$ & $\begin{array}{l}\text { Cooling Load } \\
\text { (kBtu/hr) }\end{array}$ \\
\hline SOUTH & & & & & & & & \\
\hline & $\mathbf{A}$ & 54.6 & 11 & 37.0 & 93 & 212 & 10.8 & 10.8 \\
\hline Washington & $\mathbf{A 1}$ & 40.1 & 11 & 24.1 & 93 & 212 & 7.9 & 7.9 \\
\hline & $\mathbf{B}$ & 57.8 & 11 & 33.4 & 93 & 212 & 9.9 & 9.9 \\
\hline & B1 & 50.8 & 12 & 29.4 & 93 & 212 & 8.7 & 8.7 \\
\hline & B1+ & 94.1 & 12 & 53.8 & 93 & 212 & 16.3 & 16.3 \\
\hline & C & 40.6 & 11 & 24.0 & 93 & 212 & 7.7 & 7.7 \\
\hline & D & 40.6 & 11 & 24.1 & 93 & 212 & 8.2 & 8.2 \\
\hline & D+ & 64.2 & 11 & 37.9 & 93 & 212 & 13.0 & 13.0 \\
\hline & $\mathbf{A}$ & 49.3 & 12 & 26.6 & 90 & 176 & 4.2 & 7.4 \\
\hline Atlanta & $\mathbf{A} 1$ & 34.3 & 12 & 18.9 & 91 & 175 & 4.1 & 5.7 \\
\hline & $\mathbf{B}$ & 42.4 & 12 & 21.8 & 91 & 175 & 4.4 & 6.1 \\
\hline & B1 & 34.3 & 12 & 19.3 & 91 & 175 & 4.0 & 5.6 \\
\hline & B1+ & 68.1 & 12 & 35.6 & 91 & 175 & 7.2 & 10.4 \\
\hline & C & 35.4 & 12 & 21.4 & 90 & 167 & 4.6 & 6.5 \\
\hline & D & 36.5 & 12 & 22.0 & 90 & 167 & 4.9 & 6.9 \\
\hline & $D+$ & 57.9 & 12 & 34.2 & 90 & 167 & 7.6 & 10.8 \\
\hline & $\bar{A}$ & 31.1 & 38 & 25.2 & 92 & 138 & 5.3 & 8.1 \\
\hline Miami & A1 & 21.9 & 38 & 19.5 & 89 & 201 & 7.2 & 7.2 \\
\hline & B & 25.7 & 38 & 22.2 & 89 & 201 & 7.8 & 7.9 \\
\hline & B1 & 21.4 & 38 & 18.8 & 89 & 201 & 6.7 & 6.8 \\
\hline & $\mathrm{B} 1+$ & 40.1 & 38 & 35.4 & 89 & 201 & 12.7 & 13.1 \\
\hline & C & 19.7 & 38 & 18.7 & 89 & 201 & 6.6 & 6.6 \\
\hline & D & 20.7 & 38 & 19.2 & 89 & 201 & 7.1 & 7.1 \\
\hline & $\mathrm{D}+$ & 35.6 & 38 & 31.3 & 92 & 156 & 9.3 & 11.8 \\
\hline & $\bar{A}$ & 33.6 & 20 & 27.9 & 101 & 140 & 5.0 & 7.4 \\
\hline Fort Worth & A1 & 23.5 & 20 & 21.0 & 101 & 140 & 4.4 & 6.2 \\
\hline & B & 31.3 & 20 & 25.8 & 101 & 140 & 5.0 & 7.3 \\
\hline & B1 & 24.7 & 20 & 22.1 & 101 & 140 & 4.6 & 6.4 \\
\hline & B1t & 45.3 & 20 & 38.8 & 101 & 140 & 8.1 & 11.4 \\
\hline & $\mathrm{C}$ & 28.5 & 20 & 22.0 & 101 & 140 & 4.5 & 6.3 \\
\hline & D & 31.0 & 20 & 23.5 & 101 & 140 & 4.9 & 6.8 \\
\hline & D+ & 53.1 & 20 & 38.7 & 101 & 140 & 8.1 & 11.3 \\
\hline & $\mathbf{A}$ & 30.2 & 27 & 25.7 & 89 & 154 & 7.6 & 11.7 \\
\hline New Orleans & A1 & 21.5 & 27 & 20.1 & 86 & 189 & 9.8 & 9.8 \\
\hline & B & 28.4 & 27 & 23.7 & 86 & 189 & 11.5 & 11.5 \\
\hline & B1 & 22.6 & 27 & 20.8 & 86 & 189 & 10.3 & 10.3 \\
\hline & B1+ & 41.6 & 27 & 36.1 & 86 & 189 & 18.1 & 18.1 \\
\hline & C & 26.7 & 27 & 20.7 & 86 & 189 & 10.1 & 10.1 \\
\hline & D & 27.8 & 27 & 21.6 & 86 & 189 & 10.8 & 10.8 \\
\hline & D+ & 45.5 & 27 & 35.2 & 86 & 189 & 17.8 & 17.8 \\
\hline
\end{tabular}

- Peak tempenture on day of peak load, timing of peak load may differ between prototypes in the same location.

+ Humidity ratio at peak temperature.

‡ Latent portion of total load at peak land. 
Table 12. Peak Building Loads for Single-family Prototypes (cont.)

\begin{tabular}{|c|c|c|c|c|c|c|c|c|}
\hline \multirow{2}{*}{\multicolumn{2}{|c|}{\begin{tabular}{|c|} 
Proto- \\
REGION/City type \\
\end{tabular}}} & \multicolumn{2}{|c|}{ Peak Heating } & \multirow[b]{2}{*}{$\begin{array}{c}\text { Load } \\
(\mathrm{kBtu} / \mathrm{hr})\end{array}$} & \multicolumn{2}{|c|}{ Peak Total Cooling } & \multirow[b]{2}{*}{$\begin{array}{c}\text { Lut Load } \neq \\
\text { (kBtu/hr) }\end{array}$} & \multirow{2}{*}{$\begin{array}{l}\text { Peak Latent } \\
\text { Cooling Load } \\
\text { (kBtu) }\end{array}$} \\
\hline & & $\begin{array}{c}\text { Load } \\
(\mathrm{kBtu} / \mathrm{hr})\end{array}$ & $\begin{array}{c}\text { Temp } \\
\left({ }^{\circ} \mathrm{F}\right)\end{array}$ & & $\begin{array}{c}\text { Temp* } \\
\left({ }^{\circ} \mathrm{F}\right)\end{array}$ & $\begin{array}{c}\text { HRt } \\
\left(\times 10^{4}\right)\end{array}$ & & \\
\hline \multicolumn{9}{|l|}{ WEST } \\
\hline & $\mathbf{A}$ & 47.0 & -8 & 18.6 & 95 & 61 & 0.0 & 2.0 \\
\hline \multirow[t]{8}{*}{ Denver } & A1 & 29.4 & -8 & 12.3 & 90 & 65 & 0.0 & 1.8 \\
\hline & $\mathbf{B}$ & 34.7 & -8 & 10.9 & 94 & 25 & 0.0 & 1.6 \\
\hline & B1 & 29.4 & -8 & 9.9 & 94 & 25 & 0.0 & 1.5 \\
\hline & B1+ & 59.3 & -8 & 18.8 & 92 & 61 & 0.0 & 2.5 \\
\hline & C & 39.0 & -8 & 19.4 & 90 & 65 & 0.0 & 2.4 \\
\hline & D & 38.4 & -8 & 19.2 & 90 & 65 & 0.0 & 2.5 \\
\hline & D+ & 62.5 & -8 & 30.7 & 90 & 65 & 0.0 & 3.7 \\
\hline & A & 39.1 & 12 & 23.1 & 99 & 66 & 0.0 & 3.4 \\
\hline \multirow[t]{8}{*}{ Albuquerque } & A1 & 26.5 & 12 & 14.7 & 95 & 74 & 0.3 & 2.7 \\
\hline & B & 27.6 & 12 & 14.0 & 95 & 74 & 0.3 & 2.6 \\
\hline & B1 & 23.5 & 12 & 13.1 & 95 & 74 & 0.3 & 2.4 \\
\hline & B1+ & 48.3 & 12 & 24.7 & 95 & 74 & 0.2 & 4.7 \\
\hline & $\mathbf{C}$ & 26.0 & 12 & 12.7 & 95 & 74 & 0.3 & 2.6 \\
\hline & D & 27.0 & 12 & 12.7 & 95 & 74 & 0.2 & 2.8 \\
\hline & $\mathrm{D}+$ & 45.2 & 12 & 19.8 & 95 & 74 & 0.0 & 4.5 \\
\hline & $\bar{A}$ & 31.2 & 23 & 36.0 & 103 & 104 & 3.8 & 7.7 \\
\hline \multirow[t]{8}{*}{ Phoenix } & A1 & 20.8 & 23 & 26.7 & 103 & 104 & 3.3 & 6.3 \\
\hline & $\mathbf{B}$ & 20.8 & 23 & 27.5 & 103 & 104 & 3.2 & 6.6 \\
\hline & B1 & 17.7 & 23 & 24.4 & 103 & 104 & 2.8 & 5.7 \\
\hline & B1+ & 36.5 & 23 & 49.0 & 103 & 104 & 5.6 & 10.8 \\
\hline & C & 20.6 & 23 & 27.0 & 103 & 104 & 3.4 & 6.7 \\
\hline & D & 22.0 & 23 & 28.8 & 103 & 104 & 3.7 & 7.0 \\
\hline & Dt & 37.2 & 23 & 48.1 & 103 & 104 & 6.1 & 11.0 \\
\hline & A & 54.4 & 14 & 25.4 & 87 & 104 & 1.8 & 2.3 \\
\hline \multirow{8}{*}{ Seattle } & A1 & 37.3 & 14 & 17.5 & 87 & 104 & 1.6 & 2.0 \\
\hline & B & 39.4 & 14 & 18.1 & 87 & 104 & 1.5 & 1.9 \\
\hline & B1 & 31.4 & 14 & 15.9 & 87 & 104 & 1.4 & 1.7 \\
\hline & B1+ & 54.4 & 14 & 25.9 & 87 & 104 & 2.0 & 2.5 \\
\hline & C & 41.4 & 16 & 24.6 & 89 & 100 & 1.3 & 2.5 \\
\hline & D & 40.0 & 16 & 24.7 & 89 & 100 & 1.4 & 2.6 \\
\hline & D+ & 65.1 & 16 & 39.8 & 89 & 100 & 2.1 & 4.1 \\
\hline & A & 42.7 & 37 & 26.0 & 92 & 37 & 0.0 & 1.4 \\
\hline \multirow[t]{8}{*}{ San Francisco } & A1 & 33.7 & 37 & 19.0 & 92 & 37 & 0.0 & 0.9 \\
\hline & B & 38.3 & 37 & 21.6 & 92 & 37 & 0.0 & 1.0 \\
\hline & B1 & 31.0 & 33 & 17.6 & 92 & 37 & 0.0 & 0.8 \\
\hline & B1+ & 50.8 & 33 & 29.0 & 92 & 37 & 0.0 & 1.3 \\
\hline & C & 28.0 & 37 & 21.9 & 92 & 37 & 0.0 & 1.2 \\
\hline & $\mathbf{D}$ & 28.0 & 37 & 22.6 & 92 & 37 & 0.0 & 1.3 \\
\hline & Dt & 45.5 & 37 & 36.2 & 92 & 37 & 0.0 & 2.1 \\
\hline & $\mathbf{A}$ & 37.4 & 40 & 34.9 & 102 & 47 & 0.9 & 3.5 \\
\hline \multirow[t]{7}{*}{ Los Angeles } & A1 & 29.0 & 40 & 24.6 & 102 & 47 & 0.8 & 2.7 \\
\hline & B & 33.7 & 40 & 28.8 & 102 & 47 & 0.8 & 2.6 \\
\hline & B1 & 27.8 & 40 & 22.3 & 102 & 47 & 0.7 & 2.4 \\
\hline & B1+ & 48.5 & 40 & 37.5 & 102 & 47 & 0.7 & 3.8 \\
\hline & C & 24.8 & 40 & 27.1 & 103 & 81 & 0.7 & 3.0 \\
\hline & D & 25.2 & 40 & 27.9 & 103 & 81 & 0.7 & 3.1 \\
\hline & Dt & 40.7 & 40 & 45.3 & 103 & 81 & 1.0 & 4.9 \\
\hline
\end{tabular}

- Peak tempenture on day of peak load, timing of peak load may differ betweeen prototypes in the same location.

† Humidity natio at peak temperature.

† Latent portion of toul load at peak load. 
For illustrative purposes, we present hourly space heating loads for a typical winter day in Chicago in Figure 5. In this illustration, the hourly loads are compared by building type along with the daily outdoor temperature on an hourly basis. The greatest loads are in the early morning to meet the heating requirements of the night-time $6^{\circ} \mathrm{F}$ setback. The lowest heating loads are during the early afternoon when the outside temperatures are the highest.

\section{Heating Load Intensities}

The highest heating load intensity, i.e., space heating per floor area $\left(\mathrm{kBtu} / \mathrm{ft}^{2}\right)$, were found in the oldest house with the least thermal integrity (i.e., A house). Some typical high heating load intensities, on a square foot basis, were: $99.3 \mathrm{kBtu}$ (Minneapolis), $89.8 \mathrm{kBtu}$ (Seattle), and $80.3 \mathrm{kBtu}$ (Denver). These intensities were all found in the pre-1940s construction. Table 13 contains the heating load intensities for all prototypes and locations. The peak heating load intensities are also provided in Table 13.

The lowest space heating load intensities for colder climates were found in either the D or $D+$ house. The difference in load intensities between these two prototypes was 1-2\%. Load intensities, on a square foot basis, in the colder climates ranged from $13.8 \mathrm{kBtu}$ in Denver to $20.9 \mathrm{kBtu}$ in Chicago. The lowest heating load intensities were found in locations with the smallest space heating loads (e.g., $4.2 \mathrm{kBtu} / \mathrm{ft}^{2}$ in Los Angeles and $3.7 \mathrm{kBtu} / \mathrm{ft}^{2}$ in Phoenix).

In Figure 6 we present the monthly heating load intensities for several single-family buildings in Chicago. This figure is presented to illustrate the seasonal variability of heating loads, on a square foot basis, for thermal conditions ranging from the pre-1940s house (Prototype A) to 1990s building practices (Prototype D). In addition, we show in Figure 7 the monthly heating load intensities $\left(\mathrm{kBtu} / \mathrm{ft}^{2}\right)$ for the retrofitted pre-1940s house in four climates: cold (Minneapolis), hot and humid (Miami), hot and dry (Phoenix), and moderate (San Francisco). An important observation in this illustration is the significant heating loads in San Francisco during the summer months (June, July, and August). These summer heating load intensities in San Francisco account for a large fraction of the annual heating loads in this "mild" climate.

\section{Water Heating Loads}

The domestic water heating loads ranged from $10.0 \mathrm{MMBtu} / \mathrm{yr}$ in Miami to 19.2 MMBtu/yr in Minneapolis (see Table 11). These loads were influenced primarily by the input water temperatures and hot water usage, which were based on air temperatures. Therefore, colder climates will generally have higher annual water beating loads because the assumed input water temperatures are colder. For example, the assumed average well temperatures (i.e., input water temperatures) were $49.9^{\circ} \mathrm{F}$ in the colder climates and $59.2^{\circ} \mathrm{F}$ in the warmer climates. 
Figure 5. Heating Loads on Typical Winter Day for Four Prototype Buildings in Chicago

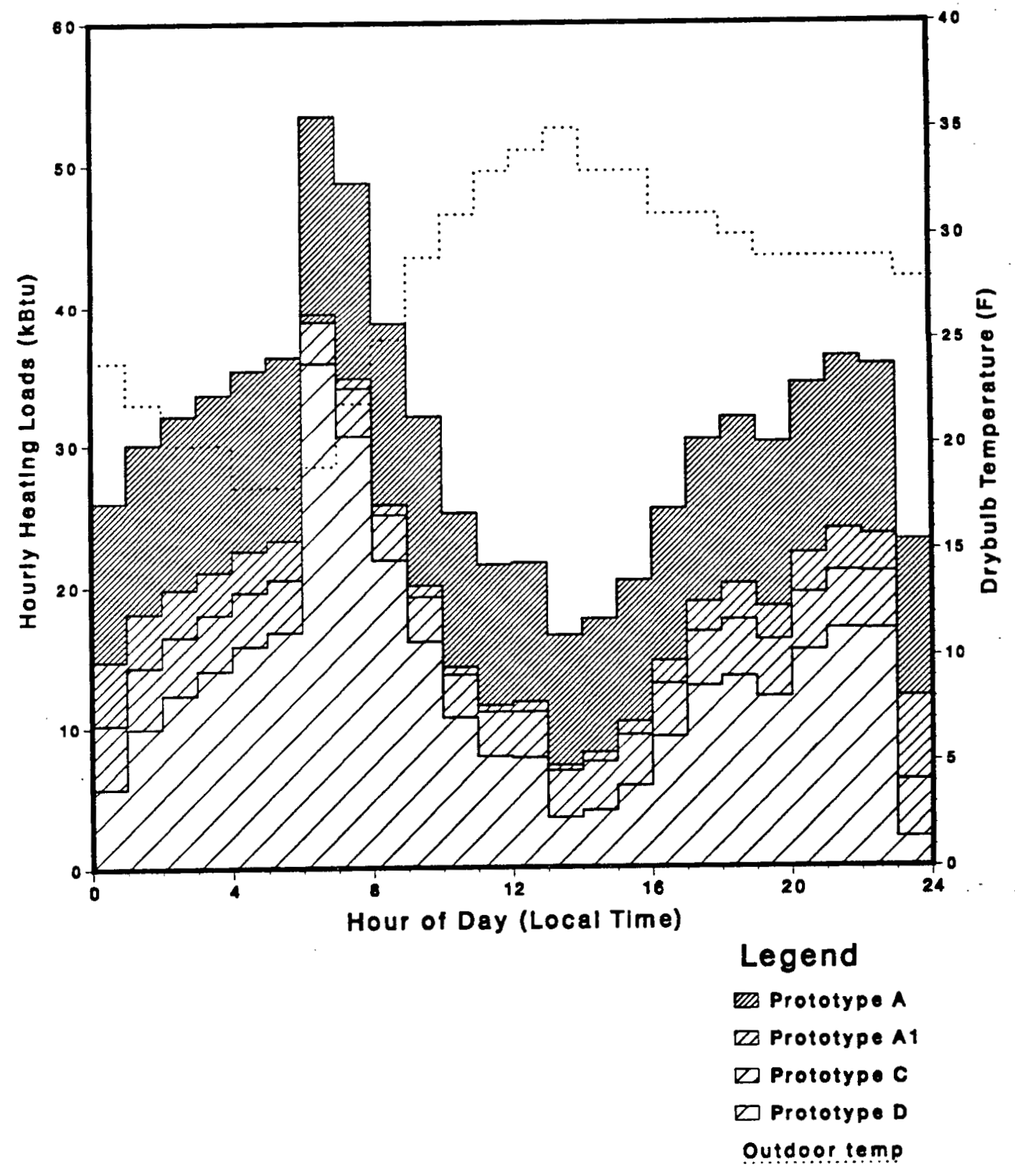


Table 13. Total and Peak Building Load Intensities for Single-family Prototypes

\begin{tabular}{|c|c|c|c|c|c|c|c|c|}
\hline \multirow[b]{2}{*}{ REGION/City } & \multirow[b]{2}{*}{$\begin{array}{l}\text { Proto- } \\
\text { Type }\end{array}$} & \multirow{2}{*}{$\begin{array}{c}\text { Heating } \\
\text { Load/ft } \\
\text { (kBtu) }\end{array}$} & \multirow{2}{*}{$\begin{array}{l}\text { Total } \\
\text { Cooling } \\
\text { Load/ft }{ }^{2} \\
(\mathrm{kBtu})\end{array}$} & \multirow{2}{*}{$\begin{array}{l}\text { Latent } \\
\text { Cooling } \\
\text { Load/ft } \\
(\mathrm{kBtu})\end{array}$} & \multirow{2}{*}{$\begin{array}{c}\text { Peak } \\
\text { Heating } \\
\text { Load } / \mathrm{ft}^{2} \\
\text { (Btu) }\end{array}$} & \multicolumn{2}{|c|}{$\begin{array}{l}\text { Peak Cooling } \\
\text { Load } / \mathrm{ft}^{2}\end{array}$} & \multirow{2}{*}{$\begin{array}{l}\text { Peak Latent } \\
\text { Cooling } \\
\text { Load/ft } \\
\text { (Btu) }\end{array}$} \\
\hline & & & & & & $\begin{array}{l}\text { Total } \\
\text { (Btu) }\end{array}$ & $\begin{array}{l}\text { Latent } \\
\text { (Btu) }\end{array}$ & \\
\hline \multicolumn{9}{|l|}{ NORTHEAST } \\
\hline & A & 74.9 & 6.9 & 1.2 & 48.7 & 24.4 & 5.5 & 6.1 \\
\hline \multirow{8}{*}{ Boston } & Al & 43.9 & 5.7 & 1.1 & 33.1 & 19.1 & 4.4 & 5.2 \\
\hline & B & 50.9 & 5.2 & 0.9 & 34.7 & 18.5 & 4.3 & 4.7 \\
\hline & B1 & 37.0 & 4.9 & 0.8 & 27.2 & 16.4 & 3.7 & 4.1 \\
\hline & Bl+ & 36.0 & 4.5 & 0.7 & 26.0 & 15.7 & 3.6 & 4.0 \\
\hline & C & 28.7 & 3.2 & 0.6 & 20.5 & 12.2 & 2.8 & 3.3 \\
\hline & D & 20.5 & 3.4 & 0.6 & 17.6 & 11.4 & 2.8 & 3.1 \\
\hline & $\mathrm{D}+$ & 20.4 & 3.1 & 0.6 & 16.9 & 10.9 & 2.7 & 3.0 \\
\hline & $\overline{\mathrm{A}}$ & 63.9 & 8.7 & 1.6 & 39.5 & 20.3 & 3.9 & 5.1 \\
\hline \multirow{7}{*}{ New York } & Al & 40.0 & 7.2 & 1.4 & 28.5 & 16.2 & 4.3 & 4.3 \\
\hline & B & 47.1 & 6.7 & 1.2 & 30.0 & 16.0 & 3.8 & 3.9 \\
\hline & B1 & 33.2 & 6.2 & 1.1 & 23.7 & 13.6 & 3.3 & 3.4 \\
\hline & $\mathrm{Bl+}$ & 32.1 & 5.4 & 0.9 & 22.0 & 12.6 & 3.2 & 3.3 \\
\hline & C & 20.8 & 4.4 & 0.9 & 16.4 & 9.7 & 2.6 & 2.7 \\
\hline & D & 17.1 & 3.8 & 0.8 & 14.3 & 8.5 & 2.4 & 2.5 \\
\hline & $\mathrm{D}+$ & 17.0 & 3.3 & 0.7 & 13.6 & 8.1 & 2.3 & 2.4 \\
\hline \multicolumn{9}{|c|}{ NORTH CENTRAL } \\
\hline & A & 76.7 & 9.9 & 1.8 & 49.7 & 22.4 & 4.4 & 6.9 \\
\hline \multirow[t]{8}{*}{ Chicago } & $\mathrm{Al}$ & 47.0 & 8.0 & 1.7 & 35.2 & 18.1 & 4.0 & 6.1 \\
\hline & B & 58.4 & 5.5 & 1.3 & 36.3 & 15.1 & 2.5 & 5.1 \\
\hline & Bl & 43.9 & 4.9 & 1.1 & 29.0 & 13.2 & 3.0 & 4.4 \\
\hline & $\mathrm{B} 1+$ & 44.6 & 3.8 & 0.8 & 28.3 & 11.7 & 2.7 & 4.1 \\
\hline & $\mathrm{C}$ & 29.5 & 4.5 & 1.0 & 21.4 & 11.4 & 2.6 & 3.8 \\
\hline & $\mathrm{D}$ & 21.2 & 4.9 & 1.0 & 17.8 & 11.0 & 2.4 & 3.6 \\
\hline & $\mathrm{D}+$ & 20.9 & 4.4 & 0.9 & 17.6 & 10.4 & 2.2 & 3.5 \\
\hline & $\bar{A}$ & 99.3 & 8.4 & 1.4 & 54.3 & 23.4 & 6.3 & 6.3 \\
\hline \multirow[t]{8}{*}{ Minneapolis } & Al & 64.4 & 7.2 & 1.5 & 38.3 & 20.7 & 6.3 & 6.3 \\
\hline & B & 85.5 & 5.7 & 1.2 & 44.7 & 19.1 & 5.6 & 5.6 \\
\hline & B1 & 58.7 & 4.7 & 1.1 & 32.6 & 16.4 & 4.9 & 4.9 \\
\hline & $\mathrm{B} 1+$ & 58.7 & 3.3 & 0.7 & 30.3 & 14.3 & 4.4 & 4.4 \\
\hline & C & 34.8 & 3.1 & 0.7 & 20.7 & 11.2 & 3.7 & 3.7 \\
\hline & $\mathrm{D}$ & 19.6 & 3.3 & 0.6 & 14.1 & 9.6 & 2.8 & 2.8 \\
\hline & D+ & 19.5 & 2.9 & 0.5 & 13.5 & 9.1 & 2.7 & 2.7 \\
\hline & A & 54.8 & 17.9 & 3.2 & 41.9 & 22.7 & 4.5 & 5.7 \\
\hline \multirow[t]{7}{*}{ Kansas City } & $\mathrm{Al}$ & 33.1 & 14.5 & 2.9 & 29.3 & 17.7 & 4.0 & 5.0 \\
\hline & B & 45.2 & 12.9 & 2.6 & 34.6 & 17.1 & 3.6 & 4.4 \\
\hline & B 1 & 28.8 & 10.6 & 2.3 & 24.9 & 13.5 & 3.5 & 3.8 \\
\hline & $\mathrm{Bl}+$ & 29.5 & 7.9 & 1.7 & 23.0 & 12.0 & 3.2 & 3.5 \\
\hline & C & 20.4 & 8.5 & 1.7 & 17.9 & 10.9 & 2.5 & 3.1 \\
\hline & D & 13.7 & 8.6 & 1.7 & 15.7 & 10.0 & 2.3 & 2.9 \\
\hline & $\mathrm{D}+$ & 13.4 & 7.9 & 1.5 & 15.1 & 9.6 & 2.3 & 2.8 \\
\hline
\end{tabular}


Table 13. Total and Peak Building Load Intensities for Single-family Prototypes (cont.)

\begin{tabular}{|c|c|c|c|c|c|c|c|c|}
\hline & & Heating & $\begin{array}{c}\text { Total } \\
\text { Cooling }\end{array}$ & $\begin{array}{l}\text { Latent } \\
\text { Cooling }\end{array}$ & $\begin{array}{c}\text { Peak } \\
\text { Heating }\end{array}$ & $\begin{array}{r}\text { Peak } \\
\text { Lo }\end{array}$ & oling & $\begin{array}{l}\text { Peak Latent } \\
\text { Cooling }\end{array}$ \\
\hline REGION/City & $\begin{array}{l}\text { Proto- } \\
\text { Type }\end{array}$ & $\begin{array}{c}\text { Load } / f^{2} \\
\text { (kBtu) }\end{array}$ & $\begin{array}{c}\mathrm{Load} / \mathrm{ft}^{2} \\
(\mathrm{kBtu})\end{array}$ & $\begin{array}{c}\mathrm{Load} / \mathrm{ft}^{2} \\
(\mathrm{kBtu})\end{array}$ & $\begin{array}{c}\mathrm{Load} / \mathrm{ft}^{2} \\
\text { (Btu) }\end{array}$ & $\begin{array}{l}\text { Total } \\
\text { (Bus) }\end{array}$ & $\begin{array}{l}\text { Latent } \\
\text { (Btu) }\end{array}$ & $\begin{array}{c}\mathrm{Load} / \mathrm{ft}^{2} \\
(\mathrm{Btu})\end{array}$ \\
\hline SOUTH & & & & & & & & \\
\hline & $\mathbf{A}$ & 53.3 & 14.7 & 3.1 & 38.7 & 26.3 & 7.7 & 7.7 \\
\hline Washington & Al & 32.4 & 11.4 & 2.3 & 28.5 & 17.1 & 5.6 & 5.6 \\
\hline & B & 38.9 & 10.7 & 1.9 & 29.4 & 17.0 & 5.0 & 5.0 \\
\hline & B1 & 26.9 & 9.7 & 1.8 & 25.9 & 15.0 & 4.4 & 4.4 \\
\hline & $\mathrm{Bl}+$ & 26.0 & 8.5 & 1.5 & 24.1 & 13.8 & 4.2 & 4.2 \\
\hline & $C$ & 17.0 & 7.4 & 1.5 & 18.6 & 11.0 & 3.5 & 3.5 \\
\hline & D & 14.3 & 6.6 & 1.4 & 17.0 & 10.1 & 3.4 & 3.4 \\
\hline & D+ & 14.2 & 5.9 & 1.2 & 16.2 & 9.6 & 3.3 & 3.3 \\
\hline & $\overline{\mathbf{A}}$ & 50.1 & 17.3 & 3.1 & 42.5 & 22.9 & 3.6 & 6.3 \\
\hline Atlanta & Al & 32.1 & 11.9 & 2.5 & 29.5 & 16.2 & 3.5 & 4.9 \\
\hline & B & 34.7 & 10.6 & 2.1 & 30.0 & 15.4 & 3.1 & 4.3 \\
\hline & B1 & 27.5 & 9.7 & 2.0 & 24.3 & 13.6 & 2.8 & 3.9 \\
\hline & B $1+$ & 28.5 & 8.0 & 1.6 & 24.0 & 12.5 & 2.5 & 3.6 \\
\hline & $C$ & 10.5 & 8.0 & 1.6 & 16.2 & 9.8 & 2.1 & 3.0 \\
\hline & $\mathrm{D}$ & 9.4 & 7.3 & 1.5 & 15.3 & 9.2 & 2.0 & 2.9 \\
\hline & $\mathrm{D}+$ & 9.4 & 6.5 & 1.3 & 14.6 & 8.6 & 1.9 & 2.7 \\
\hline & $\overline{\mathbf{A}}$ & 4.3 & 43.1 & 11.0 & 26.8 & 21.7 & 4.5 & 6.9 \\
\hline Miami & Al & 2.3 & 35.2 & 10.8 & 18.9 & 16.8 & 6.2 & 6.2 \\
\hline & B & 2.5 & 32.4 & 9.5 & 18.2 & 15.7 & 5.5 & 5.6 \\
\hline & B1 & 1.8 & 29.6 & 8.5 & 15.1 & 13.3 & 4.7 & 4.8 \\
\hline & $\mathrm{Bl}+$ & 2.1 & 24.9 & 7.2 & 14.1 & 12.4 & 4.5 & 4.6 \\
\hline & C & 1.0 & 21.6 & 6.4 & 12.2 & 11.5 & 4.1 & 4.1 \\
\hline & D & 0.9 & 19.2 & 5.8 & 11.3 & 10.5 & 3.9 & 3.9 \\
\hline & $D_{+}$ & 0.9 & 16.6 & 5.0 & 11.1 & 9.8 & 2.9 & 3.7 \\
\hline & $\overline{\mathrm{A}}$ & 31.5 & 27.1 & 5.8 & 32.0 & 26.5 & 4.7 & 7.1 \\
\hline Fort Worth & Al & 17.6 & 21.3 & 5.2 & 22.4 & 20.0 & 4.2 & 5.9 \\
\hline & B & 19.3 & 19.1 & 4.5 & 22.6 & 18.6 & 3.6 & 5.2 \\
\hline & B1 & 12.7 & 16.8 & 4.1 & 17.8 & 15.9 & 3.3 & 4.6 \\
\hline & $\mathrm{Bl+}$ & 13.0 & 14.2 & 3.4 & 17.2 & 14.7 & 3.1 & 4.3 \\
\hline & C & 13.3 & 12.9 & 3.1 & 17.6 & 13.6 & 2.8 & 3.9 \\
\hline & D & 13.0 & 11.5 & 2.8 & 16.9 & 12.8 & 2.7 & 3.7 \\
\hline & Dt & 13.4 & 10.2 & 2.4 & 16.6 & 12.1 & 2.5 & 3.5 \\
\hline & $\bar{A}$ & 17.7 & 24.9 & 6.2 & 28.8 & 24.5 & 7.2 & 11.1 \\
\hline New Orleans & Al & 8.8 & 19.5 & 5.7 & 20.4 & 19.2 & 9.4 & 9.4 \\
\hline & B & 9.9 & 17.0 & 4.8 & 20.4 & 17.1 & 8.3 & 8.3 \\
\hline & B1 & 5.9 & 15.3 & 4.6 & 16.3 & 15.0 & 7.4 & 7.4 \\
\hline & $\mathrm{Bl}+$ & 6.4 & 12.6 & 3.8 & 15.8 & 13.7 & 6.9 & 6.9 \\
\hline & C & 7.4 & 11.5 & 3.4 & 16.5 & 12.8 & 6.3 & 6.3 \\
\hline & D & 6.8 & 9.7 & 2.9 & 15.2 & 11.8 & 5.9 & 5.9 \\
\hline & $D_{+}$ & 7.2 & 8.2 & 2.4 & 14.2 & 11.0 & 5.6 & 5.6 \\
\hline
\end{tabular}


Table 13. Total and Peak Building Load Intensities for Single-family Prototypes (cont.)

\begin{tabular}{|c|c|c|c|c|c|c|c|c|}
\hline REGION/Cit & $\begin{array}{l}\text { Proto- } \\
\text { Type }\end{array}$ & $\begin{array}{c}\text { Heating } \\
\text { Load/ft } \\
\text { (kBtu) }\end{array}$ & $\begin{array}{c}\text { Total } \\
\text { Cooling } \\
\text { Load } / \mathrm{ft}^{2} \\
(\mathrm{kBtu})\end{array}$ & $\begin{array}{c}\text { Latent } \\
\text { Cooling } \\
\text { Load/ft } \\
(\mathrm{kBtu})\end{array}$ & $\begin{array}{c}\text { Peak } \\
\text { Heating } \\
\text { Load } / \mathrm{ft}^{2} \\
(\text { Btu) }\end{array}$ & $\begin{array}{r}\text { Peal } \\
\text { L } \\
\text { Total } \\
\text { (Bw) }\end{array}$ & $\begin{array}{l}\text { oling } \\
/ \mathrm{ft}^{2} \\
\text { Latent } \\
\text { (Btw) }\end{array}$ & $\begin{array}{c}\text { Peak Latent } \\
\text { Cooling } \\
\text { Load } / \mathrm{ft}^{2} \\
\text { (Btu) }\end{array}$ \\
\hline WEST & & & & & & & & \\
\hline & A & 80.3 & 9.3 & 0.1 & 48.0 & 19.0 & 0.0 & 2.0 \\
\hline Denver & Al & 42.4 & 5.0 & 0.1 & 30.0 & 12.5 & 0.0 & 1.8 \\
\hline & B & 49.2 & 3.2 & 0.0 & 32.1 & 10.1 & 0.0 & 1.5 \\
\hline & B1 & 38.5 & 3.2 & 0.0 & 27.2 & 9.2 & 0.0 & 1.4 \\
\hline & $\mathrm{B} 1+$ & 37.6 & 2.5 & 0.0 & 25.1 & 8.0 & 0.0 & 1.1 \\
\hline & C & 18.6 & 3.9 & 0.0 & 18.8 & 9.4 & 0.0 & 1.2 \\
\hline & D & 14.1 & 3.4 & 0.0 & 16.8 & 8.4 & 0.0 & 1.1 \\
\hline & D+ & 13.8 & 3.1 & 0.0 & 16.2 & 7.9 & 0.0 & 1.0 \\
\hline & $\overline{\mathrm{A}}$ & 53.7 & 16.3 & $\overline{0.3}$ & 39.9 & 23.6 & 0.0 & 3.5 \\
\hline Albuquerque & A1 & 26.1 & 9.5 & 0.3 & 27.1 & 15.1 & 0.3 & 2.8 \\
\hline & B & 29.4 & 7.6 & 0.3 & 25.5 & 12.9 & 0.3 & 2.4 \\
\hline & BI & 22.0 & 7.5 & 0.3 & 21.8 & 12.1 & 0.3 & 2.2 \\
\hline & B $1+$ & 21.7 & 6.0 & 0.1 & 20.4 & 10.5 & 0.1 & 2.0 \\
\hline & C & 13.5 & 3.9 & 0.1 & 15.6 & 7.6 & 0.2 & 1.6 \\
\hline & D & 12.0 & 3.2 & 0.1 & 14.4 & 6.8 & 0.1 & 1.5 \\
\hline & $\mathrm{D}+$ & 12.2 & 2.7 & 0.1 & 13.9 & 6.1 & 0.0 & 1.4 \\
\hline & $\bar{A}$ & 19.9 & 48.4 & 2.8 & 31.9 & 36.8 & 3.9 & 7.8 \\
\hline Phoenix & Al & 8.2 & 32.7 & 2.6 & 21.3 & 27.3 & 3.4 & 6.4 \\
\hline & B & 8.4 & 30.2 & 2.5 & 19.3 & 25.5 & 3.0 & 6.1 \\
\hline & B1 & 6.0 & 28.0 & 2.3 & 16.4 & 22.6 & 2.6 & 5.3 \\
\hline & Bl+ & 6.4 & 23.2 & 1.6 & 15.5 & 20.8 & 2.4 & 4.6 \\
\hline & C & 3.9 & 18.2 & 1.6 & 12.4 & 16.3 & 2.0 & 4.0 \\
\hline & D & 3.5 & 16.0 & 1.4 & 11.7 & 15.3 & 2.0 & 3.7 \\
\hline & $\mathrm{D}+$ & 3.7 & 14.2 & 1.1 & 11.4 & 14.8 & 1.9 & 3.4 \\
\hline & A & 89.8 & 2.2 & 0.1 & 38.7 & 18.1 & 1.3 & 1.7 \\
\hline Seatule & Al & 57.9 & 1.2 & 0.1 & 26.6 & 12.4 & 1.1 & 1.4 \\
\hline & B & 64.6 & 1.2 & 0.1 & 28.3 & 13.0 & 1.1 & 1.3 \\
\hline & B1 & 50.6 & 1.1 & 0.1 & 22.6 & 11.4 & 1.0 & 1.2 \\
\hline & B $1+$ & 51.8 & 0.9 & 0.1 & 21.9 & 10.4 & 0.8 & 1.0 \\
\hline & C & 23.9 & 1.9 & 0.1 & 20.0 & 11.9 & 0.6 & 1.2 \\
\hline & $\mathrm{D}$ & 18.4 & 1.7 & 0.1 & 17.5 & 10.8 & 0.6 & 1.1 \\
\hline & Dt & 18.4 & 1.6 & 0.1 & 16.9 & 10.3 & 0.5 & 1.1 \\
\hline & $\overline{\mathrm{A}}$ & 61.3 & 1.1 & 0.0 & 30.4 & 18.5 & 0.0 & 1.0 \\
\hline San Francisco & Al & 41.8 & 0.6 & 0.0 & 24.0 & 13.5 & 0.0 & 0.7 \\
\hline & B & 54.4 & 0.7 & 0.0 & 27.6 & 15.5 & 0.0 & 0.7 \\
\hline & B1 & 38.9 & 0.6 & 0.0 & 22.3 & 12.7 & 0.0 & 0.6 \\
\hline & B1+ & 40.2 & 0.5 & 0.0 & 20.5 & 11.7 & 0.0 & 0.5 \\
\hline & C & 12.0 & 0.5 & 0.0 & 13.5 & 10.6 & 0.0 & 0.6 \\
\hline & D & 9.2 & 0.5 & 0.0 & 12.2 & 9.9 & 0.0 & 0.6 \\
\hline & D+ & 9.3 & 0.5 & 0.0 & 11.8 & 9.4 & 0.0 & 0.5 \\
\hline & $\overline{\mathrm{A}}$ & 31.9 & 3.2 & 0.4 & 26.7 & 24.9 & 0.6 & 2.5 \\
\hline Los Angeles & Al & 20.2 & 1.6 & 0.2 & 20.6 & 17.5 & 0.6 & 2.0 \\
\hline & B & 28.1 & 1.8 & 0.2 & 24.2 & 20.7 & 0.6 & 1.9 \\
\hline & B1 & 19.1 & 1.5 & 0.2 & 20.0 & 16.1 & 0.5 & 1.7 \\
\hline & $\mathrm{Bl}+$ & 20.2 & 1.3 & 0.1 & 19.6 & 15.1 & 0.3 & 1.5 \\
\hline & C & 5.0 & 1.5 & 0.2 & 12.0 & 13.1 & 0.3 & 1.4 \\
\hline & D & 4.1 & 1.3 & 0.1 & 11.0 & 12.2 & 0.3 & 1.4 \\
\hline & D+ & 4.2 & 1.3 & 0.1 & 10.5 & 11.7 & 0.3 & 1.3 \\
\hline
\end{tabular}


Figure 6. Heating Loads/Sq.Ft.

Four Prototype Single Family Buildings In Chicago

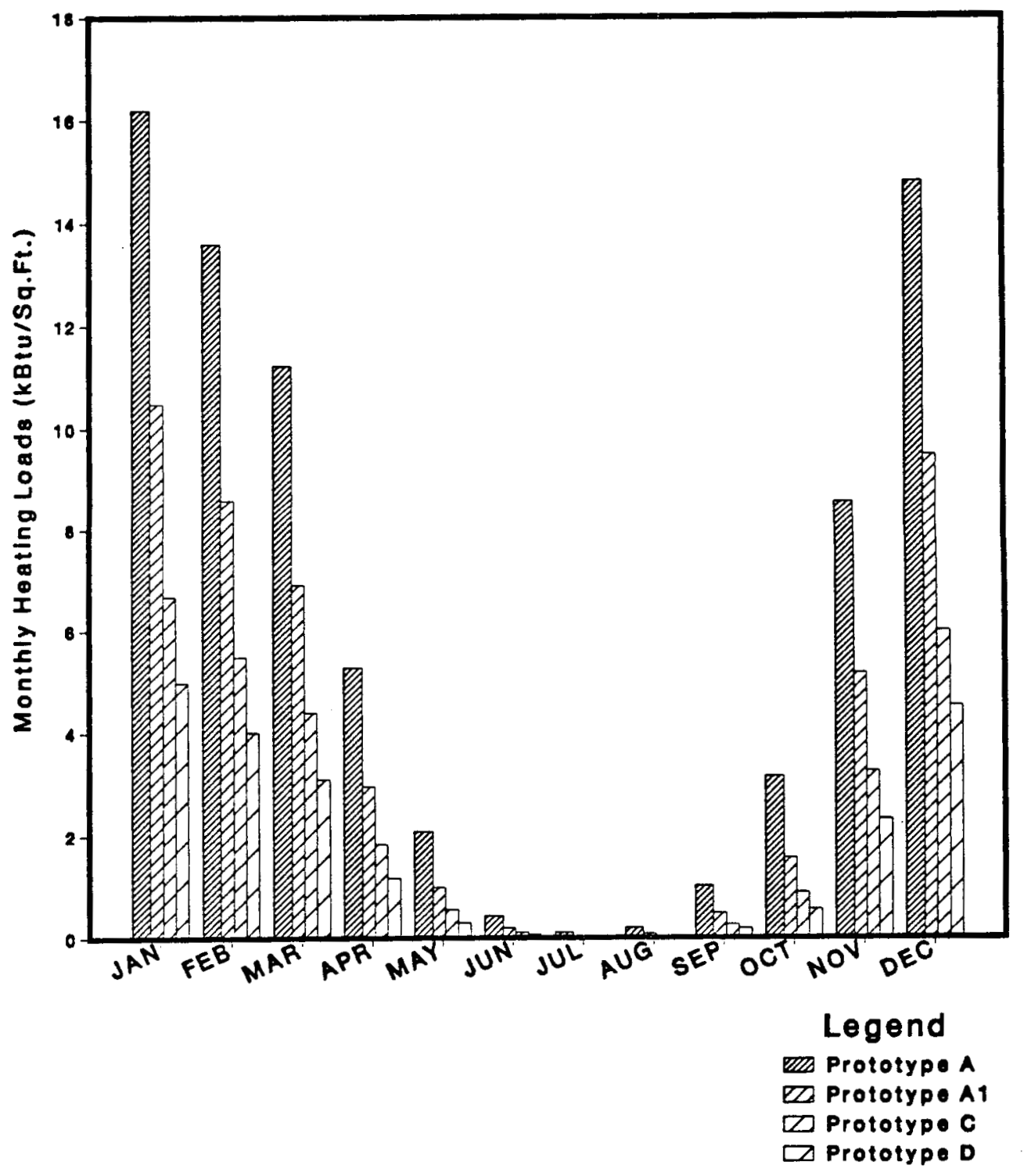


Figure 7. Heating Loads/Sq.Ft.

A1 Prototype Buildings In Four Citles

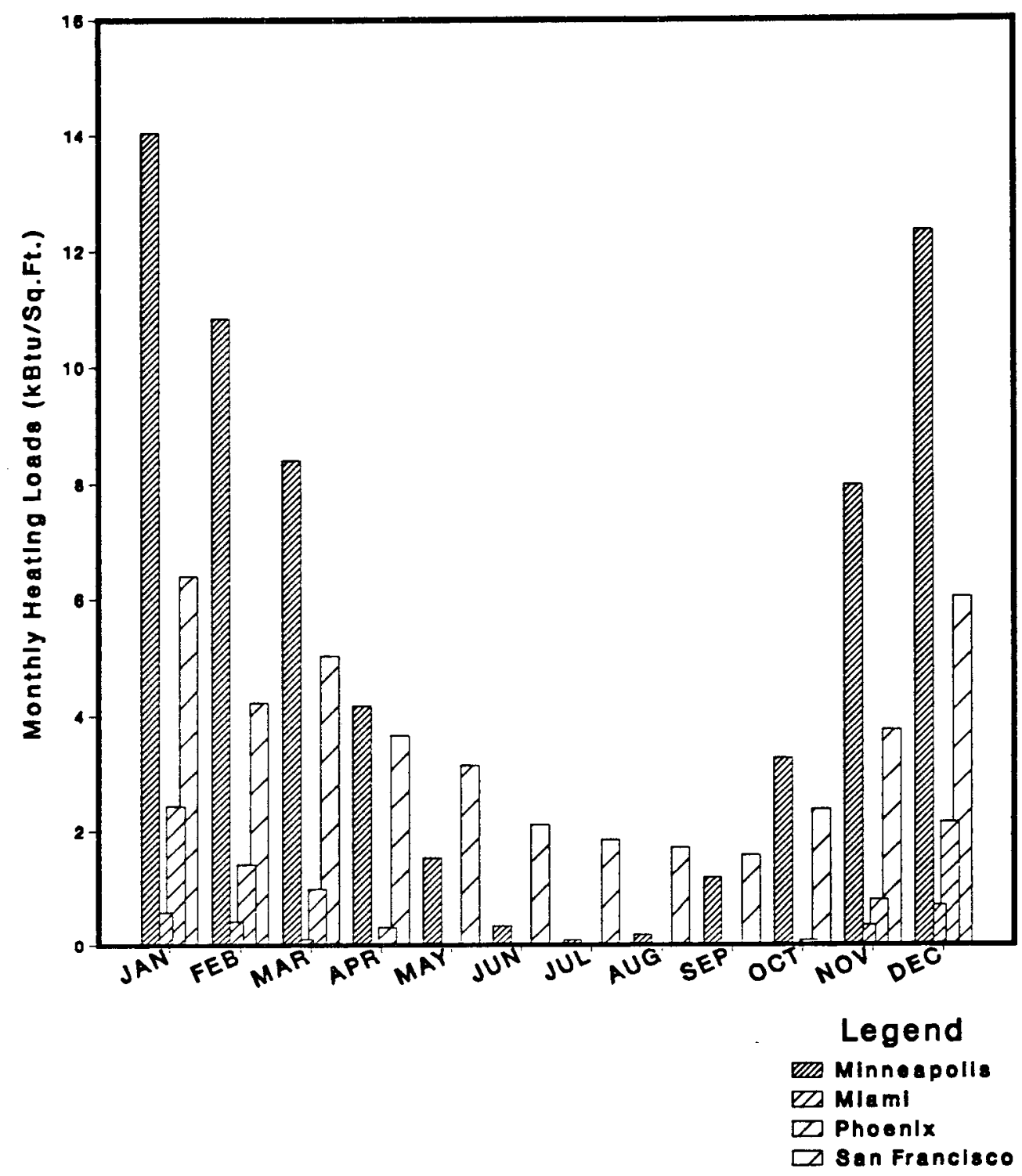


Although there was no variation in the annual water heating loads among the different prototypical houses at any locations because we assumed the same occupancy regarless of house size, there were considerable differences in the hot water use loads on a daily, weekly, and seasonal basis. A broader discussion of this topic is found in several cited references. ${ }^{38,39}$

In Figure 8 we present the domestic hot water loads, on a monthly basis, for four cities that illustrate the monthly and seasonal variation of these heating loads. This figure also shows the relationship of regional temperature differences and hot water loads. The full single-family data base will contain daily, weekly, and seasonal water heating load profiles in addition to the annual data presented in Table 11.

\section{COOLING LOADS}

The discussion of annual cooling loads generally follows the same pattern established for the heating loads data. We will first discuss the total annual space cooling loads and arrange the results in four categories: total annual loads, latent loads, peak loads, and load intensities $\left(\mathrm{kBtu} / \mathrm{ft}^{2}\right)$. As part of the peak loads, we describe both the peak cooling loads and peak latent loads since this distinction is important to those who develop and use equipment that cools interior spaces and maintains thermal comfort. The space cooling loads represent the energy requirements for the central air-conditioning system within a house that is usually fueled by electricity. Unlike the space heating loads, estimates of space cooling do not involve any temperature setups to conserve energy. However, the most recent version of the DOE-2 simulation code allows for the use of natural ventilation through the opening and closing of windows depending on the outside temperature and humidity conditions except during the assumed occupants' sleeping period (11 p.m. to 7 a.m.). As with the heating loads, the resulting cooling loads are based on "average" conditions for a population of houses and they may deviate somewhat on individual house basis.

\section{Space Cooling}

\section{Total Annual Loads}

The B1+ house (i.e., larger 1950-70 house with energy upgrades) had the highest annual cooling loads. As shown in Table 11 and Figure 9, the highest total annual loads were found in Miami (70.9 MMBtu) and Phoenix (54.8 MMBtu). In all cases, the total annual cooling loads follow the severity of weather conditions such as cooling degree-days. 
Figure 8. Domestic Hot Water Loads

In Single Famlly Bulldings for Four Cities

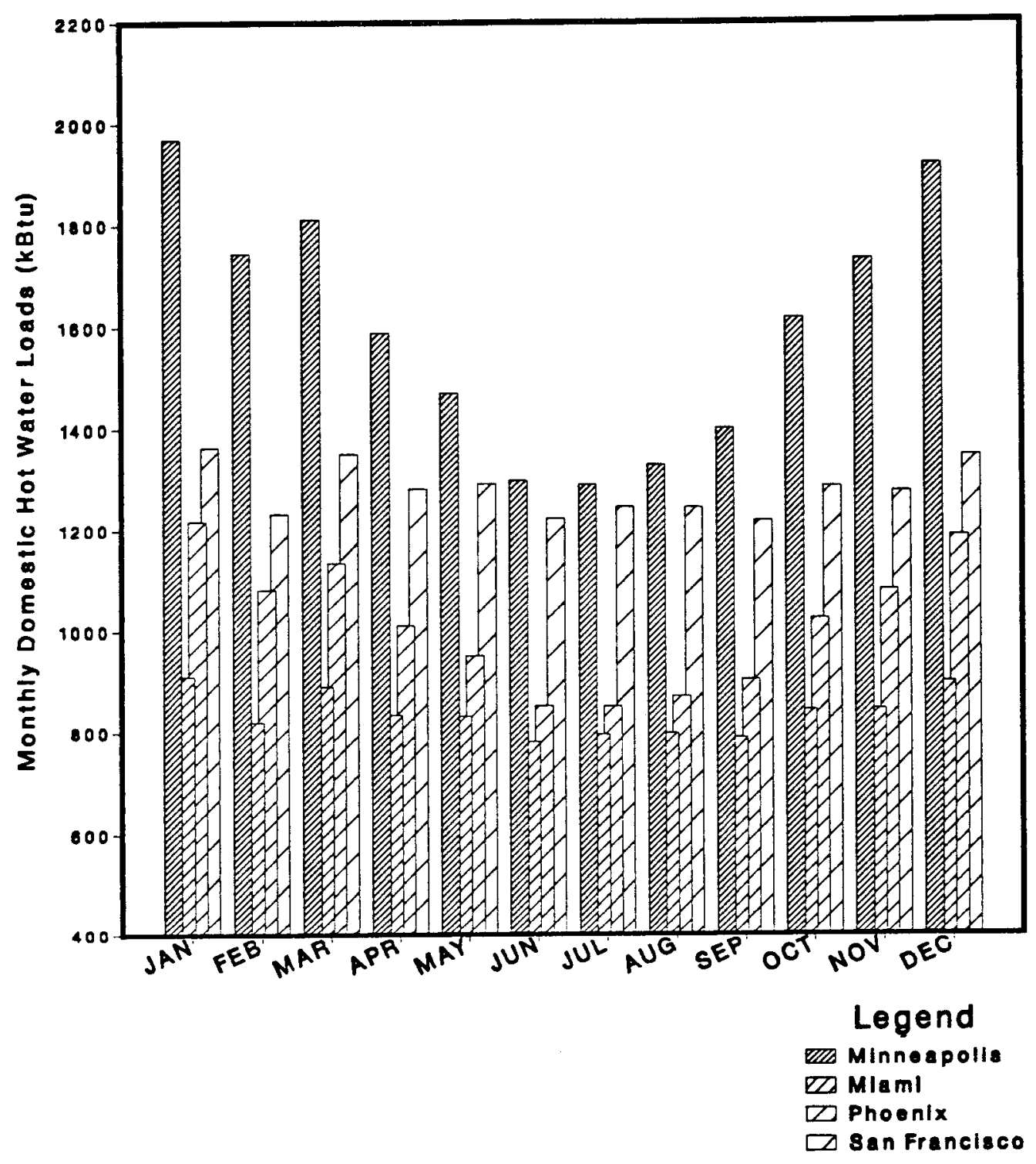


Flgure 9. Annual Coollng Loads for SIngle Famlly Prototypes

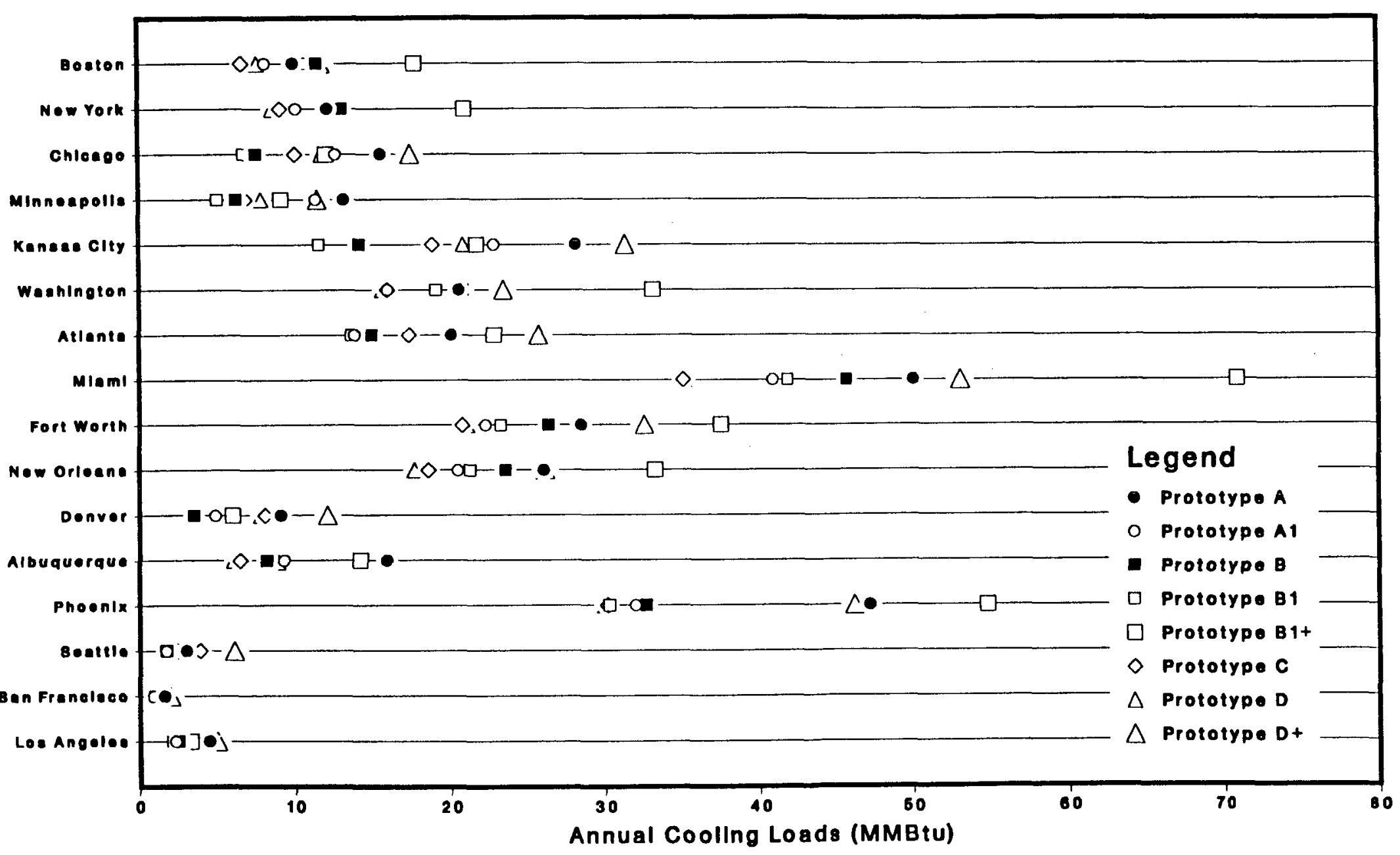


The lowest cooling loads for these same "hot climates" are found in the C or D house. The difference between these two building types is $1 \%$ to $5 \%$ on an annual basis in all locations. As an example, the annual total cooling loads in the New Orleans D house were 17.7 MMBtu, and in the Fort Worth $C$ house they were $20.8 \mathrm{MMBtu}$. In the more intermediate cooling climates the B1 house has the lowest annual cooling loads. For example, the B1 house required 4.7 MMBtu in Kansas City and 11.6 MMBtu in Atlanta. The cooling loads for a typical summer day in Chicago are shown in Figure 10. This figure shows the hourly profile over a 24-hour period for four prototypical houses. Note that cooling loads are greater for the D prototype than for the $\mathrm{C}$ prototype on this day. In addition, we also plotted the daily profile of outdoor temperatures for this summer day.

\section{Annual Latent Cooling Loads}

The highest latent cooling loads were found in Miami (see Table 11). The latent loads in Miami were highest in the larger houses (20.4 MMBtu for the B1+ house and 16.0 MMBtu for the $\mathrm{D}+$ house). In comparison, the annual latent loads in other hot cities were significantly less. For example, the $\mathrm{B} 1+$ houses in New Orleans and Fort Worth each required greater than 9 MMBtu/yr and in Kansas City (D+ house) had 6.1 MMBtu/yr. In Figure 11, we show the bourly latent cooling loads $(\mathrm{kBtu} / \mathrm{hr})$ for a typical summer day in Chicago. This figure contains hourly data on two prototypical buildings as well as the outdoor temperature for this 24hour period.

\section{Peak Cooling Loads}

Peak cooling loads are shown in Table 12 by location and by prototype. The highest peak cooling loads were found in the $\mathrm{B} 1+$ house, however, the $\mathrm{D}+$ house also had sizable peak loads. The highest peak cooling loads were found in Phoenix. The B1+ house had peak loads of $49 \mathrm{kBtu} / \mathrm{hr}$ while the $\mathrm{D}+$ house had peak cooling requirements of $48.1 \mathrm{kBtu} / \mathrm{hr}$. Surprisingly, the larger prototypes in Los Angeles where the cooling demand is generally not significant also showed large peak loads $(37.5 \mathrm{kBtu} / \mathrm{hr}$ and $45.3 \mathrm{kBtu} / \mathrm{hr}$ for the $\mathrm{B} 1+$ and $\mathrm{D}+$ houses, respectively). The lowest requirements for peak cooling were found in either the $\mathrm{C}$ or $\mathrm{D}$ house (about $1 \%$ difference) or the $\mathrm{B} 1$ house. The $\mathrm{B} 1+$ also had the highest peak latent loads (see Table 12). In the case of peak latent loads, New Orleans (18.1 kBtu/hr) and Washington D.C. (16.3 kBtu/hr) had the highest peak loads. Peak latent loads in the B1+ house in Boston and Miami were also sizable (15.5 kBtu/hr and $13.1 \mathrm{kBtu} / \mathrm{hr}$, respectively). 
Figure 10. Cooling Loads on Typical Summer Day for Four Prototype Buildings in Chicago

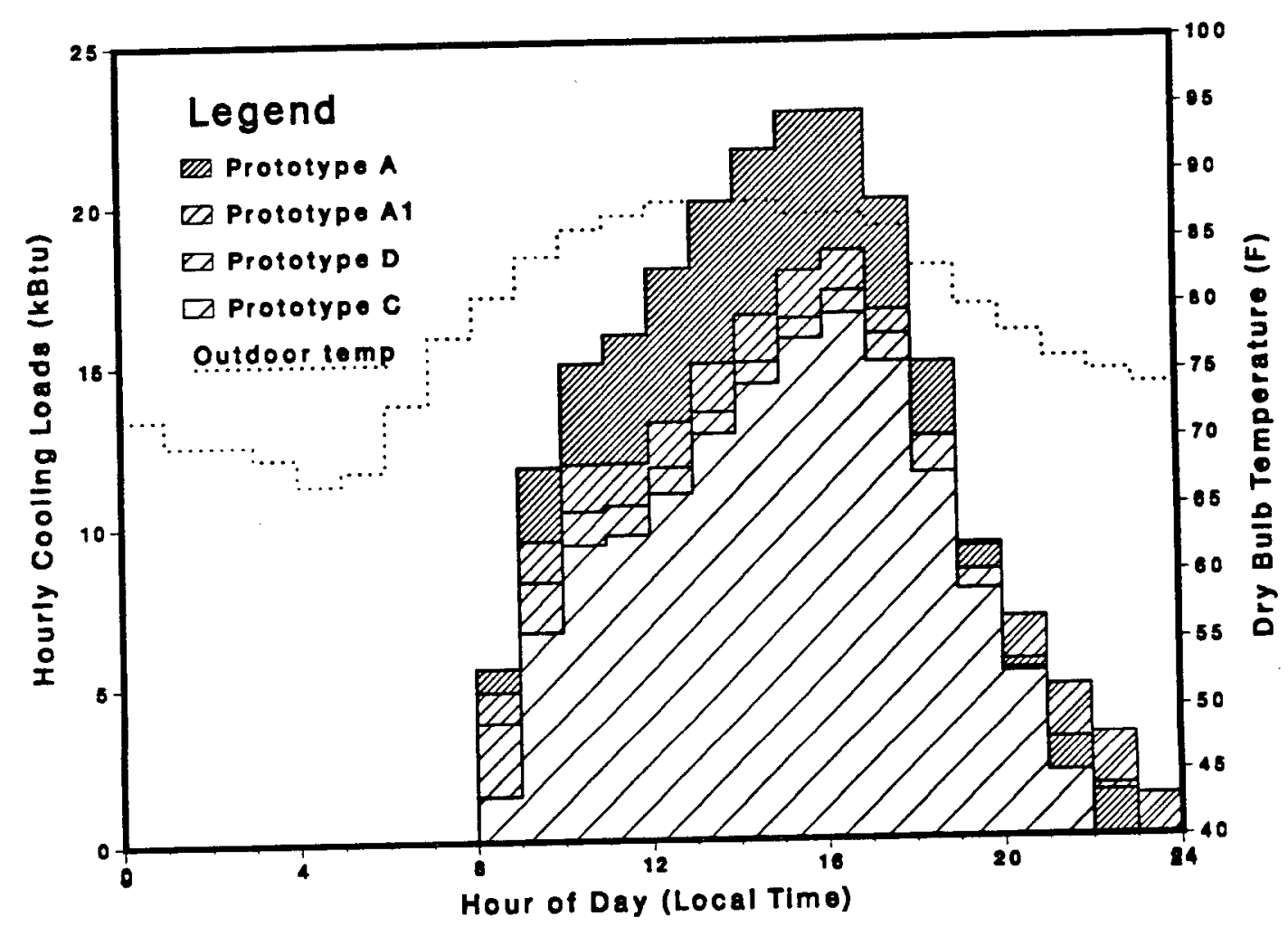

Figure 11. Latent Cooling Loads on Typlcal Summer Day for Two Prototype Bulldings in Chlcago

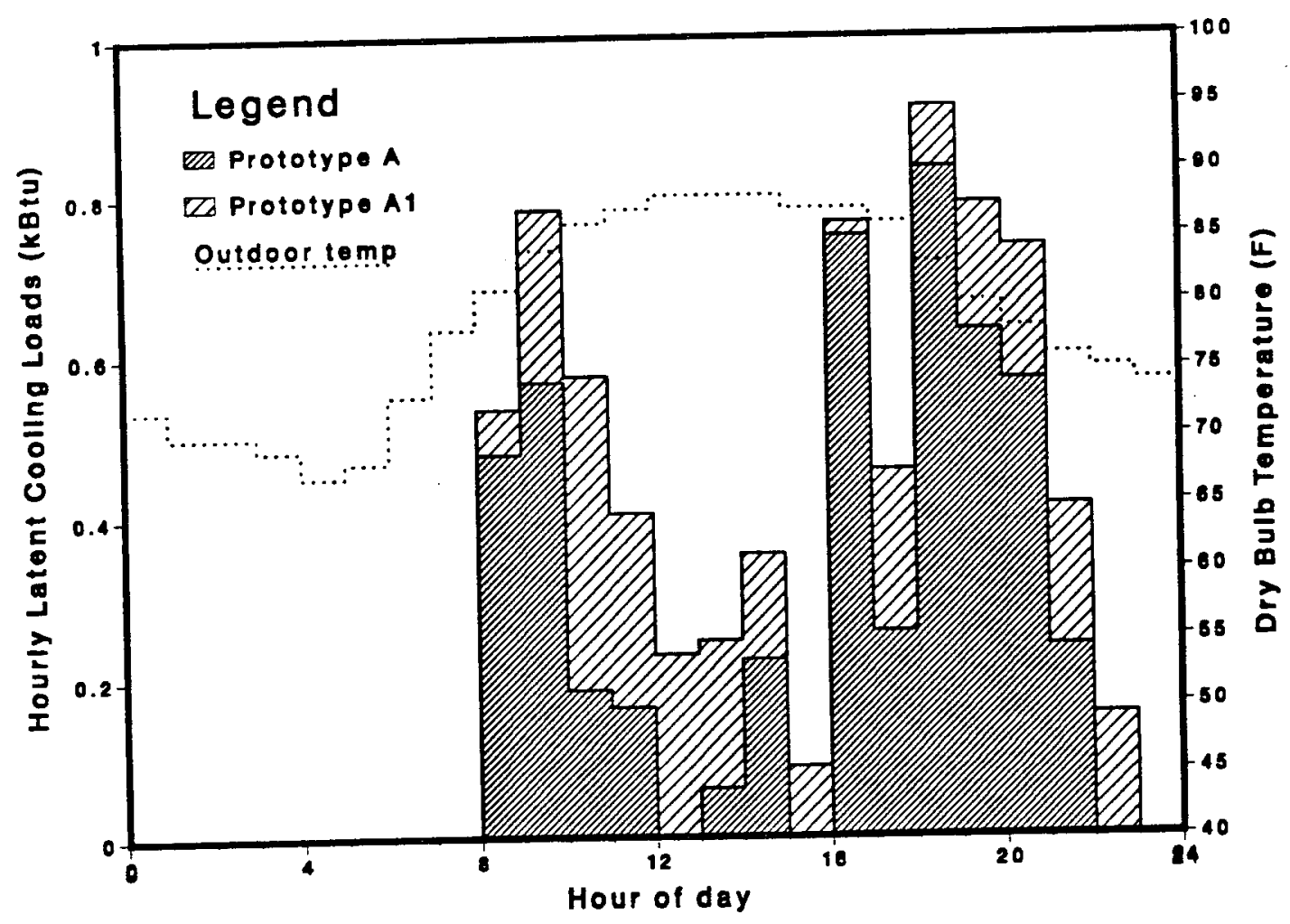




\section{Cooling Load Intensities}

Total cooling load intensities, as $\mathrm{kBtu} / \mathrm{ft}^{2}$, are shown in Table 13. The highest total cooling intensities were found in the pre-1940s house (A). The total cooling load intensities on a per square foot basis for the A house were $48.4 \mathrm{kBtu}$ in Phoenix and $43.1 \mathrm{kBtu}$ in Miami. The lowest intensities for these hot cities were all recorded in the D+ (larger 1990s) house.

As an example, total cooling load intensities in these houses were $8.2 \mathrm{kBtu}$ in New Orleans and $10.2 \mathrm{kBtu}$ in Fort Worth. Total cooling load intensities are shown for Chicago in Figure 12 where the 1990s house had higher demand $\left(\mathrm{kBtw} / \mathrm{ft}^{2}\right)$ than the 1980 s house. In Figure 13, the total cooling load intensities are shown on a monthly basis for the A1 house in four cities (Miami, Minneapolis, Phoenix, and San Francisco) that represent the major U.S. climates. This figure illustrates that there is some cooling load intensity during each month in Miami with the highest levels in the summer. On the other hand, intensities in Phoenix, which are the highest on an annual basis for the A1 house, are mostly found during the cooling months. Also, Figure 13 shows the small total cooling load intensities in the San Francisco climate.

Latent cooling load intensities as shown in Table 13 were highest in the humid climates: Miami, New Orleans, and Fort Worth. The high intensities were found in the Miami A house $\left(11.0 \mathrm{kBtu} / \mathrm{ft}^{2}\right.$ and $\mathrm{A} 1$ house $\left(10.8 \mathrm{kBtu} / \mathrm{ft}^{2}\right)$. High latent intensities were also found in the New Orleans A house $\left(6.2 \mathrm{kBtu} / \mathrm{ft}^{2}\right)$. In Figure 14 we show the latent cooling load intensities in four single-family prototypes in Chicago. We also illustrate the latent cooling load intensities of the A1 house in the four major climates (see Fig. 15). As with the total cooling loads, the Miami intensities were found throughout the year with the highest values during the summer months. The major latent cooling intensities in Phoenix were shown to occur during the socalled "monsoon months" (July through September) with a peak in August.

For peak cooling load intensities, the pre-1940s house (A house) required the highest loads per square foot. Typical load intensities in the hotter climates were $36.8 \mathrm{kBtu} / \mathrm{ft}^{2}$ in Phoenix, $26.5 \mathrm{kBtu} / \mathrm{ft}^{2}$ in Fort Worth and, $26.3 \mathrm{kBtu} / \mathrm{ft}^{2}$. The lowest peak cooling load intensities were in either the $\mathrm{D}$ or $\mathrm{D}+$ house (average and larger 1990 s prototype). The difference between these prototypes on a square foot basis was 4-5\%. The lowest loads were found in Kansas City $\left(9.6 \mathrm{kBtu} / \mathrm{ft}^{2}\right.$ and in Atlanta $\left(8.6 \mathrm{kBtu} / \mathrm{ft}^{2}\right)$.

\section{NON-HVAC LOADS}

The non-space conditioning electric loads result from the type and saturation of appliances and lighting level, which is based on the house size. Therefore the highest non-HVAC electric loads, on an annual basis, were found in the largest houses (see Table 11). The highest annual loads were either in the $\mathrm{B} 1+(1950-70)$ or $\mathrm{D}+(1990 \mathrm{~s})$ prototypes. For example, annual 
Figure 12. Total Cooling Loads/Sq.Ft.

Four Prototype Single Family Buildings In Chicago

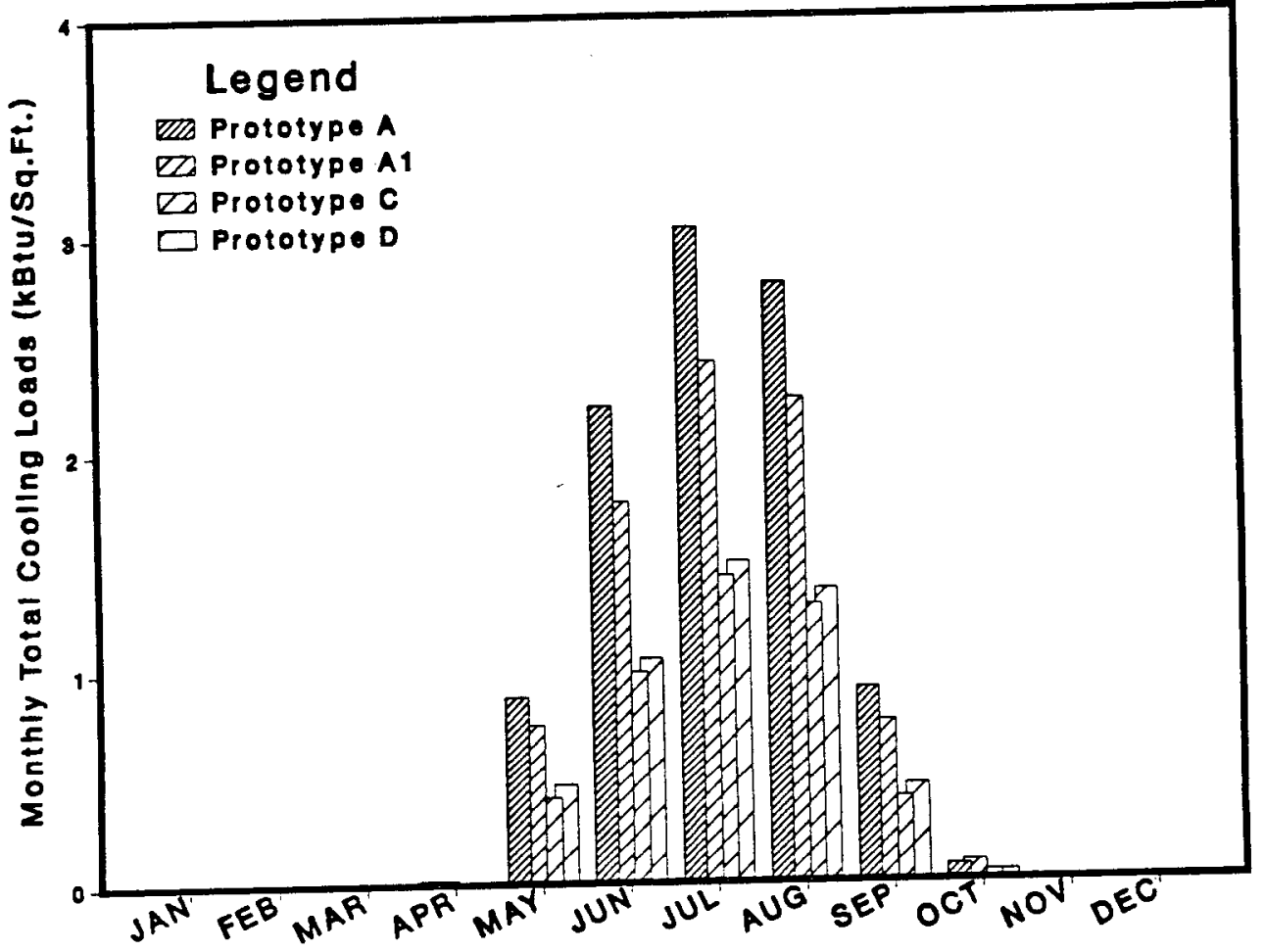

Figure 13. Total Cooling Loads/Sq.Ft.

A1 Prototype Buildings in Four Cities

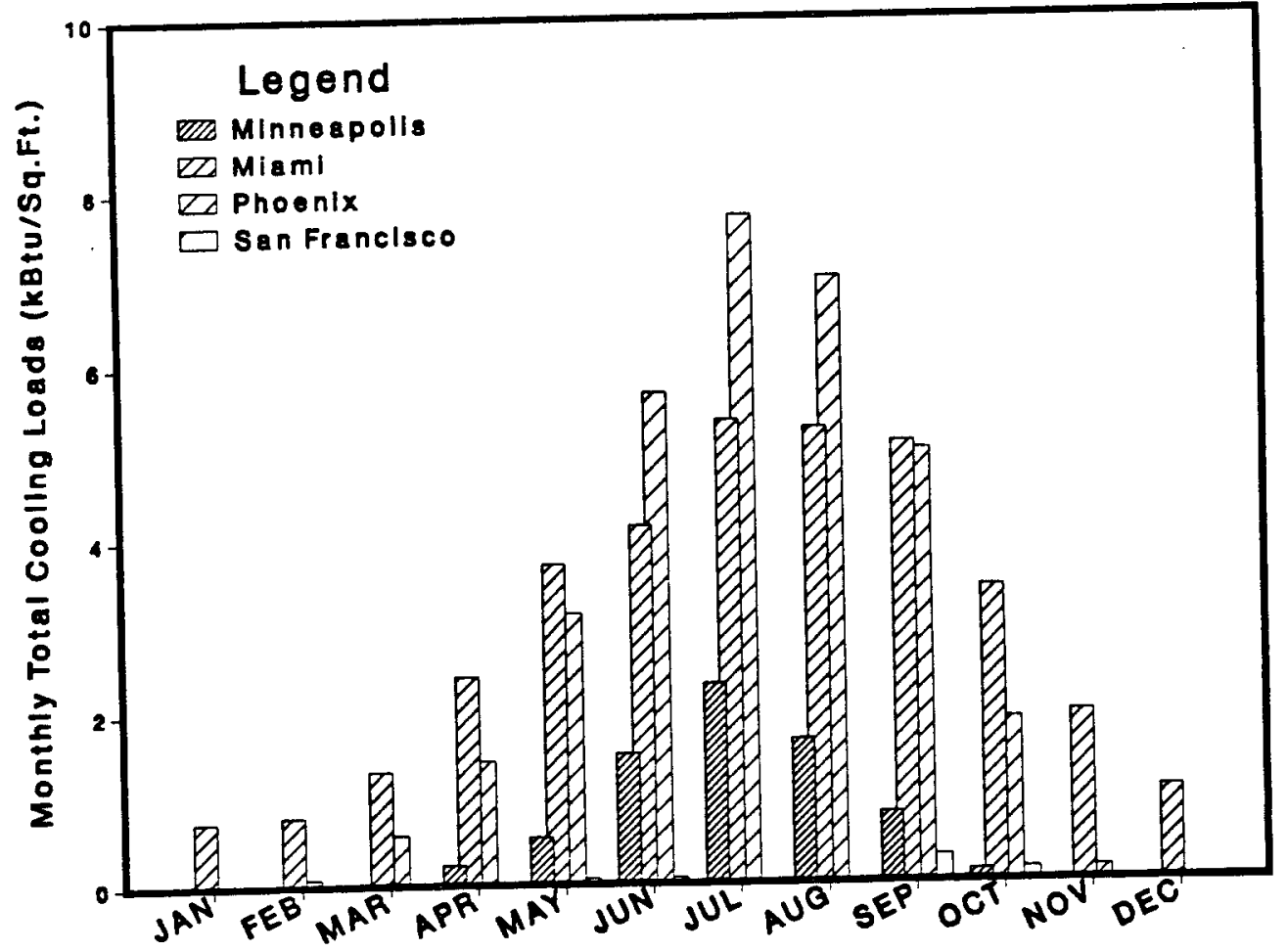

48 
Figure 14. Latent Cooling Loads/Sq.Ft.

Four Prototype Single Famlly Bulldings In Chicago

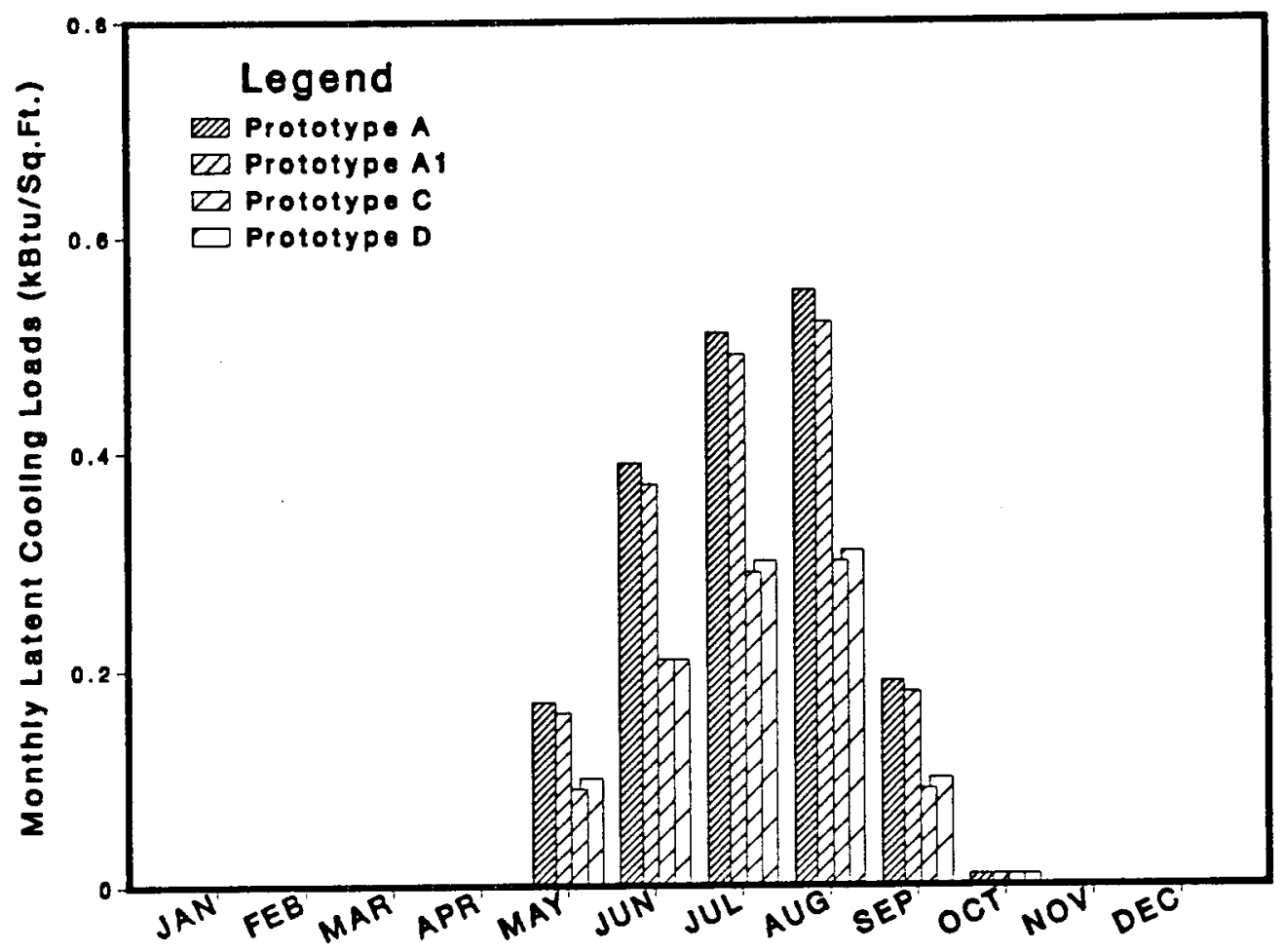

Figure 15. Latent Cooling Loads/Sq.Ft. A1 Prototype Buildings in Four Cities

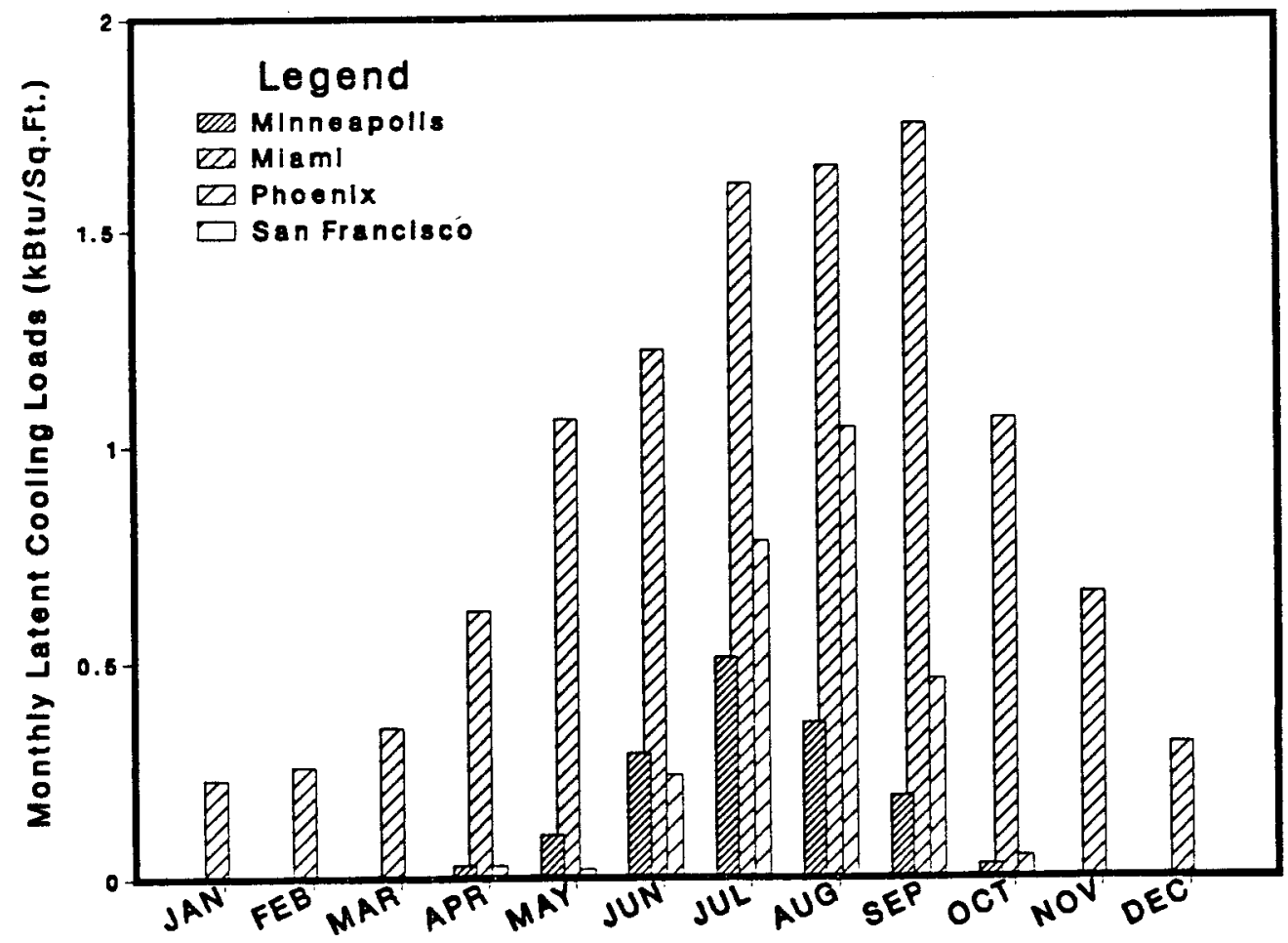


electricity loads in New York were $9507 \mathrm{kWh}$, Boston followed with $9207 \mathrm{kWh}$, and Chicago with $8641 \mathrm{kWh}$. In general, the non-HVAC electricity loads in the colder climates were greater than $8000 \mathrm{kWh}$ per year.

The non-HVAC gas loads were only represented in the West South Central Census Division (i.e., Fort Worth and New Orleans) where natural gas was assumed as the major cooking fuel. The difference between the older houses (pre-1940s to 1980 s prototypes) had an estimated annual gas load of $9.0 \mathrm{MMBtu}$, while the 1990 s houses had annual loads that were reduced by about $46 \%$ (4.9 MMBtu/yr).

\section{TOTAL ANNUAL SPACE CONDITIONING LOADS}

To provide some estimate of the total annual loads, we calculated the total annual space conditioning loads on a square foot basis. Load intensities were used to remove the bias of house size. In all cases, the pre-1940s houses had the largest total loads. Since the loads were driven by space heating, the highest total annual loads were found in Minneapolis (107.7 $\mathrm{MMBtu} / \mathrm{ft}^{2}$ ), followed by the other cities with more than 5500 heating degree-days (at base $65^{\circ} \mathrm{F}$ ), i.e., Denver (89.6 MMBtu/ft${ }^{2}$ ) and Chicago (86.6 MMBtu/ft ${ }^{2}$ ). In the case of those cities with high cooling degree-days (greater than 1600), Kansas City had the highest total annual space conditioning loads $\left(72.7 \mathrm{MMBtu} / \mathrm{ft}^{2}\right)$. Unlike the other hot climates, Kansas City also has an average of 4799 heating degree-days.

\section{COMPARISON TO MEASURED AND SURVEYED DATA}

This section provides a preliminary comparison between the single-family data base heating and cooling loads and surveyed and measured building energy use data. Since the loads data base will be used to assess new gas technologies, it is important to determine how well the calculated loads agree with actual building loads. A more thorough comparison was recently completed for the multifamily data base that showed good agreement with measured and surveyed data. 42

The simulated loads are compared to energy use data from two sources. The first is surveyed energy data from the 1987 Residential Energy Consumption Survey (RECS) Public Use Data Tape. ${ }^{9}$ The second source is measured energy use from the BECA-B compilation at LBL, which is a data base of retrofit energy savings in single-family buildings in the US. ${ }^{42}$

Several issues make the comparison between the simulated loads and measured energy use data a difficult task. First, measured and surveyed data are typically recorded as energy use, not building loads. Thus, measured data include the effects of equipment efficiency, and some estimation of the typical efficiency must be made before the data are comparable. Secondly, energy use data are often collected from utility bills or in some other aggregated form. Direct comparison of end uses such as heating, cooling, or hot water heating is impossible without making some further assumptions. Third, the use of alternative heating fuels such 
as wood heat and portable heaters may reduce the apparent space heat use by the primary heating fuel in many locations. Lastly, the simulated loads represent average buildings and average operating conditions. On the other hand, there is a great deal of variation in building characteristics and occupant behavior in real buildings which can not be simulated. The intent is that the building loads will be representative of average conditions for large samples of buildings.

To make the comparison easier and more robust, we first aggregated the simulated loads by census division and vintage. For each census division we developed three sets of loads; for pre-1940s (average of A and A1 prototypes, referred to here as A), 1950-1970 (average of B and $B 1$ prototypes, referred to as B), and 1980 (C Prototype) vintage buildings. The aggregated loads, shown in Table 14, are calculated as weighted average values based on the building populations given in Appendix B. These aggregations allow the comparison to regional average or smaller samples of building energy use data.

\section{RECS Survey Data}

One of the most comprehensive sources of measured energy consumption data is the RECS data available from the Energy Information Administration. For this study, we analyzed the 1987 RECS data tape. The data contains a sample of 3799 single-family detached buildings, each of which is weighted so that 55.2 million buildings are represented by the sample. We sorted the sample of single-family buildings and energy use data in the RECS data base by census division and vintage to match the aggregated loads data. The sampled buildings were further categorized according to space and water heating fuel and system type (e.g., electric resistance vs. heat pumps) and by the presence of electric air-conditioning.

Because RECS contains only fuel use data, we used simple techniques to disaggregate the energy use values into broad end uses for the comparison. The data allowed us to separate the entire space and water heat sample into those with and without fuel cooking, and determine a fuel use value for cooking of $8.2 \mathrm{kBtu} / \mathrm{ft}^{2}$. This value was subtracted from the fuel use for buildings with fuel cooking to derive combined energy use for space and water heating. We then removed those buildings with air-conditioning from this sample, and calculated median electric use for buildings with and without electric cooking. This calculation showed no significant difference in electricity use between buildings with and without electric cooking. However, the calculation showed a median value of $13.2 \mathrm{kBtu} / \mathrm{ft}^{2}$ for non-HVAC electric consumption. We subtracted this value from electricity usage in all buildings so that electricity use represented only space heat, water heat, and cooling, where applicable.

By far the greatest proportion of the buildings in the RECS data use fuel for space and water heating. In fact, after sorting the sample buildings by census division and vintage and 
Table 14. Aggregated Building Loads for Single-family Database Comparison

\begin{tabular}{|c|c|c|c|c|c|c|c|c|c|c|c|}
\hline $\begin{array}{l}\text { Census } \\
\text { Pivision }\end{array}$ & $\begin{array}{l}\text { Proto- } \\
\text { Type }\end{array}$ & $\begin{array}{l}\text { Floor } \\
\text { Area } \\
\left(\mathrm{ft}^{2}\right)\end{array}$ & $\begin{array}{l}\text { Popu- } \\
\text { lation } \\
\text { (1000s) }\end{array}$ & $\begin{array}{c}\text { Heat } \\
\text { (MMBtw) }\end{array}$ & $\begin{array}{c}\text { Cool } \\
\text { (MMBw) }\end{array}$ & $\begin{array}{c}\text { DHW } \\
\text { (MMBtu) }\end{array}$ & $\begin{array}{c}\text { non-HVAC } \\
\text { Elec } \\
(\mathrm{MMBw})\end{array}$ & $\begin{array}{c}\text { Heal } \\
\left(\mathrm{kBw} / \mathrm{f}^{2}\right)\end{array}$ & $\begin{array}{c}\text { Cool } \\
\left(\mathrm{kBtu} / \mathrm{f}^{2}\right)\end{array}$ & $\begin{array}{c}\text { Heat+ } \\
\text { DHW } \\
\text { (MMBw) }\end{array}$ & $\begin{array}{c}\text { Heat } \\
\text { DHW } \\
\left(\mathrm{kBw} / \mathrm{ft}^{2}\right)\end{array}$ \\
\hline \multirow[t]{3}{*}{ NEW ENGLAND } & $\begin{array}{l}\text { A } \\
\text { Al } \\
\text { Toual }\end{array}$ & $\begin{array}{l}1440 \\
1440 \\
1440\end{array}$ & $\begin{array}{l}235 \\
454 \\
689\end{array}$ & $\begin{array}{r}107.8 \\
63.2 \\
78.4\end{array}$ & $\begin{array}{r}10.0 \\
8.2 \\
8.8\end{array}$ & $\begin{array}{l}17.8 \\
17.8 \\
17.8\end{array}$ & $\begin{array}{l}21.3 \\
21.3 \\
21.3\end{array}$ & $\begin{array}{l}74.9 \\
43.9 \\
54.5\end{array}$ & $\begin{array}{l}6.9 \\
5.7 \\
6.1\end{array}$ & $\begin{array}{r}125.6 \\
81.0 \\
96.2\end{array}$ & $\begin{array}{l}87.2 \\
56.3 \\
66.8\end{array}$ \\
\hline & $\begin{array}{l}\text { B } \\
\text { B 1 } \\
\text { Total } \\
\end{array}$ & $\begin{array}{l}2220 \\
2220 \\
2220 \\
\end{array}$ & $\begin{array}{r}93 \\
417 \\
510 \\
\end{array}$ & $\begin{array}{r}13.1 \\
82.2 \\
87.8 \\
\end{array}$ & $\begin{array}{l}11.5 \\
10.9 \\
11.0 \\
\end{array}$ & $\begin{array}{l}17.8 \\
17.8 \\
17.8 \\
\end{array}$ & $\begin{array}{l}24.0 \\
24.0 \\
24.0\end{array}$ & $\begin{array}{l}50.9 \\
37.0 \\
39.6 \\
\end{array}$ & $\begin{array}{l}5.2 \\
4.9 \\
5.0\end{array}$ & $\begin{array}{l}130.9 \\
100.0 \\
105.6\end{array}$ & $\begin{array}{l}59.0 \\
45.0 \\
47.6 \\
\end{array}$ \\
\hline & $\overline{\mathbf{C}}$ & 2090 & 279 & 60.1 & 6.7 & 17.8 & 23.5 & 28.8 & 3.2 & 77.9 & 37.3 \\
\hline \multirow[t]{3}{*}{ MID-ATLANTIC } & $\begin{array}{l}\text { A } \\
\text { Al } \\
\text { Total }\end{array}$ & $\begin{array}{l}1400 \\
1400 \\
1400\end{array}$ & $\begin{array}{r}527 \\
1050 \\
1577\end{array}$ & $\begin{array}{l}90.0 \\
56.3 \\
67.6\end{array}$ & $\begin{array}{l}12.2 \\
10.2 \\
10.9\end{array}$ & $\begin{array}{l}16.6 \\
16.6 \\
16.6\end{array}$ & $\begin{array}{l}22.1 \\
22.1 \\
22.1\end{array}$ & $\begin{array}{l}64.3 \\
40.2 \\
48.3\end{array}$ & $\begin{array}{l}8.7 \\
7.3 \\
7.8\end{array}$ & $\begin{array}{r}106.6 \\
72.9 \\
84.2\end{array}$ & $\begin{array}{l}76.2 \\
52.1 \\
60.1\end{array}$ \\
\hline & $\begin{array}{l}\text { B } \\
\text { B1 } \\
\text { Total }\end{array}$ & $\begin{array}{l}1960 \\
1960 \\
1960 \\
\end{array}$ & $\begin{array}{l}184 \\
606 \\
790\end{array}$ & $\begin{array}{l}92.4 \\
65.1 \\
71.5 \\
\end{array}$ & $\begin{array}{l}13.1 \\
12.1 \\
12.3 \\
\end{array}$ & $\begin{array}{l}16.6 \\
16.6 \\
16.6 \\
\end{array}$ & $\begin{array}{l}24.0 \\
24.0 \\
24.0 \\
\end{array}$ & $\begin{array}{l}47.1 \\
33.2 \\
36.5 \\
\end{array}$ & $\begin{array}{l}6.7 \\
6.2 \\
6.3 \\
\end{array}$ & $\begin{array}{r}109.0 \\
81.7 \\
88.1 \\
\end{array}$ & $\begin{array}{l}55.6 \\
41.7 \\
44.9 \\
\end{array}$ \\
\hline & $\overline{\mathbf{C}}$ & 2090 & 436 & 43.4 & 9.2 & 16.6 & 24.5 & 20.8 & 4.4 & 60.0 & 28.7 \\
\hline \multirow[t]{3}{*}{ CENTRAL } & $\begin{array}{l}\text { A } \\
\text { Al } \\
\text { Total }\end{array}$ & $\begin{array}{l}1580 \\
1580 \\
1580 \\
\end{array}$ & $\begin{array}{r}596 \\
1431 \\
2027\end{array}$ & $\begin{array}{r}120.8 \\
74.0 \\
87.8 \\
\end{array}$ & $\begin{array}{l}15.6 \\
12.7 \\
13.6\end{array}$ & $\begin{array}{l}17.3 \\
17.3 \\
17.3\end{array}$ & $\begin{array}{l}22.1 \\
22.1 \\
22.1\end{array}$ & $\begin{array}{l}76.5 \\
46.8 \\
55.5\end{array}$ & $\begin{array}{l}9.9 \\
8.0 \\
8.6\end{array}$ & $\begin{array}{r}138.1 \\
91.3 \\
105.0\end{array}$ & $\begin{array}{l}87.4 \\
57.8 \\
66.5 \\
\end{array}$ \\
\hline & $\begin{array}{l}\text { B } \\
\text { B } 1 \\
\text { Total }\end{array}$ & $\begin{array}{l}1380 \\
1380 \\
1380 \\
\end{array}$ & $\begin{array}{r}291 \\
1526 \\
1817\end{array}$ & $\begin{array}{l}80.6 \\
60.5 \\
63.7\end{array}$ & $\begin{array}{l}7.6 \\
6.8 \\
6.9\end{array}$ & $\begin{array}{l}17.3 \\
17.3 \\
17.3 \\
\end{array}$ & $\begin{array}{l}21.4 \\
21.4 \\
21.4 \\
\end{array}$ & $\begin{array}{l}58.4 \\
43.8 \\
46.2 \\
\end{array}$ & $\begin{array}{l}5.5 \\
4.9 \\
5.0 \\
\end{array}$ & $\begin{array}{l}97.9 \\
77.8 \\
81.0 \\
\end{array}$ & $\begin{array}{l}70.9 \\
56.4 \\
58.7 \\
\end{array}$ \\
\hline & $\bar{C}$ & 2220 & 442 & 65.5 & 10.1 & 17.3 & 24.3 & 29.5 & 4.5 & 82.8 & 37.3 \\
\hline \multirow[t]{3}{*}{ CENTRAL } & $\begin{array}{l}\text { A } \\
\text { A1 } \\
\text { Total }\end{array}$ & $\begin{array}{l}1580 \\
1580 \\
1580\end{array}$ & $\begin{array}{l}203 \\
598 \\
801\end{array}$ & $\begin{array}{r}121.4 \\
76.8 \\
88.1\end{array}$ & $\begin{array}{l}20.7 \\
17.2 \\
18.0\end{array}$ & $\begin{array}{l}17.6 \\
17.6 \\
17.6\end{array}$ & $\begin{array}{l}22.3 \\
22.3 \\
22.3\end{array}$ & $\begin{array}{l}76.8 \\
48.6 \\
55.8\end{array}$ & $\begin{array}{l}13.1 \\
10.9 \\
11.4\end{array}$ & $\begin{array}{r}139.0 \\
94.4 \\
105.7\end{array}$ & $\begin{array}{l}87.9 \\
59.8 \\
66.9\end{array}$ \\
\hline & $\begin{array}{l}\text { B } \\
\text { B1 } \\
\text { Total }\end{array}$ & $\begin{array}{l}1100 \\
1100 \\
1100\end{array}$ & $\begin{array}{r}186 \\
943 \\
1129 \\
\end{array}$ & $\begin{array}{l}71.9 \\
48.2 \\
52.1 \\
\end{array}$ & $\begin{array}{r}10.3 \\
8.4 \\
8.7 \\
\end{array}$ & $\begin{array}{l}17.6 \\
17.6 \\
17.6 \\
\end{array}$ & $\begin{array}{l}20.6 \\
20.6 \\
20.6 \\
\end{array}$ & $\begin{array}{l}65.4 \\
43.8 \\
47.3 \\
\end{array}$ & $\begin{array}{l}9.3 \\
7.6 \\
7.9 \\
\end{array}$ & $\begin{array}{l}89.5 \\
65.8 \\
69.7 \\
\end{array}$ & $\begin{array}{l}81.4 \\
59.8 \\
63.3 \\
\end{array}$ \\
\hline & $\bar{C}$ & 2220 & 175 & 59.3 & 13.6 & 17.4 & 24.5 & 26.7 & 6.1 & 76.7 & 34.6 \\
\hline \multirow[t]{3}{*}{ SOUTH ATLANTIC } & $\begin{array}{l}\text { A } \\
\text { Al } \\
\text { Toual } \\
\end{array}$ & $\begin{array}{l}1165 \\
1165 \\
1165 \\
\end{array}$ & $\begin{array}{l}302 \\
379 \\
681 \\
\end{array}$ & $\begin{array}{l}46.1 \\
28.6 \\
36.3 \\
\end{array}$ & $\begin{array}{l}30.3 \\
23.6 \\
26.6 \\
\end{array}$ & $\begin{array}{l}13.2 \\
13.2 \\
13.2\end{array}$ & $\begin{array}{l}19.4 \\
19.4 \\
19.4\end{array}$ & $\begin{array}{l}39.6 \\
24.5 \\
31.2 \\
\end{array}$ & $\begin{array}{l}26.0 \\
20.3 \\
22.8\end{array}$ & $\begin{array}{l}59.3 \\
41.8 \\
49.5 \\
\end{array}$ & $\begin{array}{l}50.9 \\
35.9 \\
42.5 \\
\end{array}$ \\
\hline & $\begin{array}{l}\text { B } \\
\text { B! } \\
\text { Toal }\end{array}$ & $\begin{array}{l}1415 \\
1415 \\
1415\end{array}$ & $\begin{array}{r}533 \\
847 \\
1380 \\
\end{array}$ & $\begin{array}{l}43.0 \\
31.4 \\
35.9\end{array}$ & $\begin{array}{l}27.2 \\
24.9 \\
25.8\end{array}$ & $\begin{array}{l}13.2 \\
13.2 \\
13.2\end{array}$ & $\begin{array}{l}20.3 \\
20.3 \\
20.3\end{array}$ & $\begin{array}{l}30.4 \\
22.2 \\
25.4 \\
\end{array}$ & $\begin{array}{l}19.2 \\
17.6 \\
18.2 \\
\end{array}$ & $\begin{array}{l}56.2 \\
44.6 \\
49.1 \\
\end{array}$ & $\begin{array}{l}39.7 \\
31.5 \\
34.7\end{array}$ \\
\hline & $\mathbf{C}$ & 1910 & 1367 & 16.6 & 25.5 & 12.5 & 22.0 & 7.7 & 14.4 & 29.1 & 14.3 \\
\hline WEST SOUTH & A & 1055 & 106 & 25.8 & 27.3 & 12.2 & 15.8 & 24.5 & 25.9 & 38.0 & 36.0 \\
\hline \multirow[t]{3}{*}{ CENTRAL } & $\begin{array}{l}\text { Al } \\
\text { Toal }\end{array}$ & $\begin{array}{l}1055 \\
1055 \\
\end{array}$ & $\begin{array}{r}46 \\
152 \\
\end{array}$ & $\begin{array}{l}13.9 \\
22.2 \\
\end{array}$ & $\begin{array}{l}21.4 \\
25.5 \\
\end{array}$ & $\begin{array}{l}12.2 \\
12.2 \\
\end{array}$ & $\begin{array}{l}15.8 \\
15.8 \\
\end{array}$ & $\begin{array}{l}13.2 \\
21.0 \\
\end{array}$ & $\begin{array}{l}20.3 \\
24.2 \\
\end{array}$ & $\begin{array}{l}26.1 \\
34.4 \\
\end{array}$ & $\begin{array}{l}24.7 \\
32.6 \\
\end{array}$ \\
\hline & $\begin{array}{l}\text { B } \\
\text { B1 } \\
\text { Toal }\end{array}$ & $\begin{array}{l}1390 \\
1390 \\
1390\end{array}$ & $\begin{array}{l}270 \\
454 \\
724 \\
\end{array}$ & $\begin{array}{l}20.2 \\
12.9 \\
15.6 \\
\end{array}$ & $\begin{array}{l}25.0 \\
22.3 \\
23.3 \\
\end{array}$ & $\begin{array}{l}12.2 \\
12.2 \\
12.2 \\
\end{array}$ & $\begin{array}{l}16.9 \\
16.9 \\
16.9 \\
\end{array}$ & $\begin{array}{r}14.5 \\
9.3 \\
11.2 \\
\end{array}$ & $\begin{array}{l}18.0 \\
16.0 \\
16.8 \\
\end{array}$ & $\begin{array}{l}32.4 \\
25.1 \\
27.8 \\
\end{array}$ & $\begin{array}{l}23.3 \\
18.0 \\
20.0 \\
\end{array}$ \\
\hline & $\overline{\mathbf{C}}$ & 1620 & 270 & 19.5 & 20.4 & 12.4 & 17.7 & 12.1 & 12.6 & 31.9 & 19.7 \\
\hline \multirow[t]{3}{*}{ MOUNTAIN } & $\begin{array}{l}\text { A } \\
\text { Al } \\
\text { Total } \\
\end{array}$ & $\begin{array}{l}975 \\
975 \\
975 \\
\end{array}$ & $\begin{array}{r}60 \\
129 \\
189 \\
\end{array}$ & $\begin{array}{l}50.2 \\
25.0 \\
33.0 \\
\end{array}$ & $\begin{array}{l}24.1 \\
15.4 \\
18.2 \\
\end{array}$ & $\begin{array}{l}14.9 \\
14.9 \\
14.9 \\
\end{array}$ & $\begin{array}{l}19.6 \\
19.6 \\
19.6 \\
\end{array}$ & $\begin{array}{l}51.5 \\
25.7 \\
33.9 \\
\end{array}$ & $\begin{array}{l}24.7 \\
15.8 \\
18.6\end{array}$ & $\begin{array}{l}65.1 \\
40.0 \\
47.9\end{array}$ & $\begin{array}{l}66.8 \\
41.0 \\
49.2\end{array}$ \\
\hline & $\begin{array}{l}\text { B } \\
\text { B1 } \\
\text { Toual }\end{array}$ & $\begin{array}{l}1080 \\
1080 \\
1080 \\
\end{array}$ & $\begin{array}{r}81 \\
239 \\
320 \\
\end{array}$ & $\begin{array}{l}31.3 \\
23.9 \\
25.8\end{array}$ & $\begin{array}{l}14.8 \\
14.0 \\
14.2 \\
\end{array}$ & $\begin{array}{l}14.9 \\
14.9 \\
14.9\end{array}$ & $\begin{array}{l}19.9 \\
19.9 \\
19.9 \\
\end{array}$ & $\begin{array}{l}29.0 \\
22.2 \\
23.9\end{array}$ & $\begin{array}{l}13.7 \\
12.9 \\
13.1\end{array}$ & $\begin{array}{l}46.3 \\
38.9 \\
40.7\end{array}$ & $\begin{array}{l}42.8 \\
36.0 \\
37.7\end{array}$ \\
\hline & $\overline{\mathbf{C}}$ & 1816 & 292 & 20.5 & 19.1 & 14.7 & 22.4 & 10.6 & 11.2 & 35.2 & 18.6 \\
\hline \multirow[t]{3}{*}{ PACIFIC } & $\begin{array}{l}\text { A } \\
\text { Al } \\
\text { Total }\end{array}$ & $\begin{array}{l}1400 \\
1400 \\
1400\end{array}$ & $\begin{array}{l}395 \\
328 \\
723\end{array}$ & $\begin{array}{l}85.6 \\
56.1 \\
72.2\end{array}$ & $\begin{array}{l}3.0 \\
1.6 \\
2.4\end{array}$ & $\begin{array}{l}15.5 \\
15.5 \\
15.5\end{array}$ & $\begin{array}{l}21.1 \\
21.1 \\
21.1\end{array}$ & $\begin{array}{l}61.1 \\
40.0 \\
51.6\end{array}$ & $\begin{array}{l}2.2 \\
1.2 \\
1.7\end{array}$ & $\begin{array}{r}101.1 \\
71.6 \\
87.7\end{array}$ & $\begin{array}{l}72.2 \\
51.1 \\
62.6\end{array}$ \\
\hline & $\begin{array}{l}\text { B } \\
\text { B1 } \\
\text { Toual }\end{array}$ & $\begin{array}{l}1390 \\
1390 \\
1390 \\
\end{array}$ & $\begin{array}{r}779 \\
1498 \\
2277 \\
\end{array}$ & $\begin{array}{l}68.2 \\
50.4 \\
56.5 \\
\end{array}$ & $\begin{array}{l}1.7 \\
1.5 \\
1.6 \\
\end{array}$ & $\begin{array}{l}15.5 \\
15.5 \\
15.5 \\
\end{array}$ & $\begin{array}{l}21.1 \\
21.1 \\
21.1\end{array}$ & $\begin{array}{l}49.1 \\
36.3 \\
40.6 \\
\end{array}$ & $\begin{array}{l}1.2 \\
1.1 \\
1.1 \\
\end{array}$ & $\begin{array}{l}83.7 \\
65.9 \\
72.0 \\
\end{array}$ & $\begin{array}{l}60.2 \\
47.4 \\
51.8 \\
\end{array}$ \\
\hline & $\overline{\mathbf{C}}$ & 2070 & 388 & 25.2 & 2.6 & 15.3 & 23.4 & 12.2 & 1.2 & 40.4 & 19.5 \\
\hline
\end{tabular}


then further by heating and DHW fuel, some categories had too few data points to be reliable and gave widely varying energy use values. Since the space heat and water heat category was well represented in all categories, the analysis focuses on those buildings. Air conditioning usage was also derived from buildings in this subsample which used electricity for space cooling. The results from these calculations are compared with the simulated loads in Table 15 and Figures 16 through 19.

Because the RECS data are reported as energy use, and not loads, we made assumptions about the range of efficiencies that is expected in residential fuel heating systems. We used similar combustion equipment efficiencies as in the multifamily data comparison study ${ }^{5}$, except that the lower range was set at $60 \%$ rather than $55 \%$ to account for the absence of large central heating systems in single-family buildings. The range in annual coefficient of performance (COP) for the cooling end use was assumed to range from 1.8 to 2.2 based on simulated annual cooling system performance in the DOE-2 calculations using a steady-state airconditioner COP of 2.7 .

\section{BECA Measured Data}

The BECA-B data base contains measured data from a large number of retrofit projects across the U.S., including utility programs, research projects, and state and local loan programs. In almost all of the projects in the sample, space beating is the targeted end use. Space heat usage is either measured directly or it is derived from aggregate fuel use using regression or degree-day analysis. Pre- and post-retrofit energy and/or space heat use is recorded along with other building and project data.

We chose projects from the BECA sample that contained good quality energy data (based on the authors' rating), the presence of building floor area data, and a suitable number of buildings in the sample. We calculated energy use per unit area from the data as given in the report. Loads were calculated at efficiencies of $65 \%$ for fuel end uses and $3.413 \mathrm{kBtu} / \mathrm{kWh}$ for electric end uses, and are compared with the pre- and post-retrofit data with the aggregated building loads in Table 16 and Figures 20 and 21.

\section{Comparison Results}

While this comparison is a preliminary analysis, it allows us to make some broad observations about the simulated data. The first observation is that the simulated heating loads are within the range covered by the RECS energy use values for most prototypes and locations. However, the simulated loads for the A and B prototypes in the East North Central and West North Central census divisions differ by up to $20 \%$. The comparison of the simulated loads with the BECA data for these locations is much better. The RECS data for these locations appears to be low, since these census divisions contain the coldest climates in the country. The simulated and RECS data for the $\mathrm{C}$ prototypes are more comparable. 
Table 15. RECS Analysis Summary - Building Loads by Census Division and Prototype

\begin{tabular}{|c|c|c|c|c|c|c|c|c|c|c|c|c|c|c|}
\hline & \multicolumn{3}{|c|}{ Simulated Laads } & \multicolumn{5}{|c|}{ RECS Fuel Heat Sample } & \multicolumn{5}{|c|}{ RECS Fuel Heat w/Cooling Sample } \\
\hline & & \multirow{3}{*}{$\frac{\begin{array}{c}\text { Heat } \\
\left(\mathrm{kBw} / \mathrm{ft}^{2}\right)\end{array}}{54.5}$} & \multirow{3}{*}{$\frac{\begin{array}{c}\mathrm{Cool} \\
\left(\mathrm{kBw} / \mathrm{ft}^{2}\right)\end{array}}{6.1}$} & \multirow{3}{*}{$\begin{array}{c}\begin{array}{c}\text { Heat+ } \\
\mathrm{DHW} \\
\left(\mathrm{kBw} / \mathrm{ft}^{2}\right)\end{array} \\
66.8\end{array}$} & \multirow{3}{*}{\begin{tabular}{|c|}
$\begin{array}{c}\text { Pop. } \\
\text { n }\end{array}$ \\
49
\end{tabular}} & \multirow{3}{*}{$\begin{array}{c}\begin{array}{c}\text { Wtd. } \\
\text { Pop. } \\
(1000 \mathrm{~s})\end{array} \\
408\end{array}$} & \multirow{3}{*}{$\begin{array}{c}\begin{array}{c}\text { Healt } \\
\text { DHW }\end{array} \\
\left(\mathrm{kBw} / \mathrm{ft}^{2}\right)\end{array}$} & \multicolumn{2}{|c|}{ Efficiency } & \multirow[b]{2}{*}{$\begin{array}{c}\text { Pop. } \\
n\end{array}$} & \multirow{3}{*}{$\begin{array}{l}\text { Wid. } \\
\text { Pop. } \\
(1000 s)\end{array}$} & \multirow{2}{*}{$\begin{array}{c}\text { Elec } \\
\text { Cool } \\
\left(\mathrm{kBtw} / \mathrm{f}^{2}\right)\end{array}$} & \multicolumn{2}{|c|}{ COP } \\
\hline & & & & & & & & $\begin{array}{c}75 \% \\
\left(\mathrm{kBtw} / \mathrm{ft}^{2}\right)\end{array}$ & $\begin{array}{c}60 \% \\
\left(k \mathrm{Bw} / \mathrm{ft}^{2}\right)\end{array}$ & & & & $\begin{array}{c}1.8 \\
\left(\mathrm{kBw} / \mathrm{ft}^{2}\right)\end{array}$ & $\begin{array}{c}2.2 \\
\left(\mathrm{kBw} / \mathrm{ft}^{2}\right)\end{array}$ \\
\hline$\overline{\mathrm{NeE}}$ & $\mathbf{A}$ & & & & & & & 79.5 & 63.6 & & & & & \\
\hline $\mathrm{NeE}$ & B & 39.6 & 5.0 & 47.6 & 64 & 596 & 65.1 & 48.8 & 39.1 & & & & & \\
\hline NeE & C & 28.8 & 3.2 & 37.3 & 5 & 70 & 38.0 & 28.5 & 22.8 & & & & & \\
\hline MdA & A & 48.3 & 7.8 & 60.1 & 91 & 1560 & 82.1 & 61.6 & 49.3 & & & & & \\
\hline MdA & B & 36.5 & 6.3 & 44.9 & 116 & 1911 & 75.0 & 56.3 & 45.0 & & & & & \\
\hline MdA & C & 20.8 & 4.4 & 28.7 & 13 & 291 & 49.9 & 37.4 & 29.9 & & & & & \\
\hline ENC & A & 55.5 & 8.6 & 66.5 & 153 & 2313 & 70.2 & 52.7 & 421 & 27 & 481 & 21 & 3.8 & 4.6 \\
\hline ENC & B & 46.2 & 5.0 & 58.7 & 99 & 1969 & 69.4 & 52.1 & 41.6 & 35 & 745 & 24 & 4.3 & 5.3 \\
\hline ENC & C & 29.5 & 4.5 & 37.3 & 18 & 299 & 60.4 & 45.3 & 36.2 & & & & & \\
\hline WNC & $\mathbf{A}$ & 55.8 & 11.4 & 66.9 & 134 & 1177 & 70.8 & 53.1 & 425 & 39 & 368 & 3.9 & 7.0 & 8.6 \\
\hline WNC & B & 47.3 & 7.9 & 63.3 & 116 & 1006 & 57.4 & 43.1 & 34.4 & 77 & 692 & 4.1 & 7.4 & 9.0 \\
\hline WNC & C & 26.7 & 6.1 & 34.6 & 20 & 224 & 40.5 & 30.4 & 24.3 & 16 & 185 & 6.5 & 11.7 & 14.3 \\
\hline SOA & A & 31.2 & 22.8 & 42.5 & 44 & 701 & 61.3 & 46.0 & 36.8 & & & & & \\
\hline SOA & B & 25.4 & 18.2 & 34.7 & 68 & 1423 & 55.5 & 41.6 & 33.3 & 42 & 922 & 6.3 & 11.3 & 13.9 \\
\hline SOA & C & 7.7 & 14.4 & 14.3 & 5 & 123 & 49.5 & 37.1 & 29.7 & & & & & \\
\hline ESC & $\mathbf{A}$ & & & & 50 & 361 & 100.9 & 75.7 & 60.5 & & & & & \\
\hline ESC & B & & & & 52 & 590 & 60.2 & 45.2 & 36.1 & 32 & 406 & 11.0 & 19.8 & 24.2 \\
\hline ESC & C & & & & 5 & 71 & 48.5 & 36.4 & 29.1 & & & & & \\
\hline wsc & A & 21.0 & 24.2 & 32.6 & 43 & 553 & 61.1 & 45.8 & 36.7 & & & & & \\
\hline wsc & B & 11.2 & 16.8 & 20.0 & 138 & 2698 & 54.9 & 41.2 & 32.9 & 58 & 1371 & 13.6 & 24.5 & 29.9 \\
\hline wsc & C & 12.1 & 12.6 & 19.7 & 12 & 261 & 29.8 & 22.4 & 17.9 & & & & & \\
\hline Min & A & 33.9 & 18.6 & 49.2 & 49 & 436 & 84.6 & 63.5 & 50.8 & & & & & \\
\hline Mtn & B & 23.9 & 13.1 & 37.7 & 88 & 796 & 60.2 & 45.2 & 36.1 & 24 & 220 & 7.4 & 13.3 & 16.3 \\
\hline Min & C & 10.6 & 11.2 & 18.6 & 19 & 202 & 36.9 & 27.7 & 22.1 & & & & & \\
\hline Pac & A & 51.6 & 1.7 & 62.6 & 60 & 905 & 41.2 & 30.9 & 24.7 & & & & & \\
\hline $\mathrm{Pac}$ & B & 40.6 & 1.1 & 51.8 & 127 & 2036 & 44.6 & 33.5 & 26.8 & 29 & 470 & 3.2 & 5.8 & 7.0 \\
\hline Pac & C & 12.2 & 1.2 & 19.5 & 24 & 405 & 38.3 & 28.7 & 23.0 & 11 & 205 & 1.1 & 2.0 & 2.4 \\
\hline
\end{tabular}

Table 16. BECA-B Results Summary - Building Loads by Census Division and Prototype

\begin{tabular}{|c|c|c|c|c|c|c|c|c|c|c|c|c|c|c|}
\hline \multirow[b]{2}{*}{$\begin{array}{l}\text { Division/ } \\
\text { Prototype }\end{array}$} & \multirow[b]{2}{*}{$\begin{array}{l}\text { BECA } \\
\text { Cade }\end{array}$} & \multirow[b]{2}{*}{ Loc. } & \multirow[b]{2}{*}{$\begin{array}{c}\text { Pop. } \\
\mathbf{n}\end{array}$} & \multirow[b]{2}{*}{$\begin{array}{l}\text { Avg. } \\
\text { Ares } \\
\left(\mathrm{ft}^{2}\right)\end{array}$} & \multirow[b]{2}{*}{$\begin{array}{l}\text { Retro } \\
\text { fits }\end{array}$} & \multirow[b]{2}{*}{$\begin{array}{l}\text { Fuel } \\
\text { End } \\
\text { uses }\end{array}$} & \multicolumn{2}{|c|}{ Fuel End Use } & \multicolumn{2}{|c|}{ Space Heat } & \multicolumn{2}{|c|}{ Fuel Use/ft ${ }^{2}$} & \multicolumn{2}{|c|}{ Space Heat $/ \mathrm{ft}^{2}$} \\
\hline & & & & & & & $\begin{array}{c}\text { Pre } \\
\text { (MMBtu/ } \\
\text { kWh) }\end{array}$ & $\begin{array}{c}\text { Post } \\
\text { (MMBtu/ } \\
\text { kWh) }\end{array}$ & $\begin{array}{c}\text { Pre } \\
\text { (MMBw/ } \\
\text { kWh) }\end{array}$ & $\begin{array}{c}\text { Post } \\
\text { (MMBw/ } \\
\text { kWh) }\end{array}$ & $\begin{array}{c}\text { Pre } \\
\text { (kBw/ } \\
k W h)\end{array}$ & $\begin{array}{l}\text { Post } \\
\text { (kBu/ } \\
\text { kWh) }\end{array}$ & $\begin{array}{c}\text { Pre } \\
\text { (kBtu/ } \\
\text { kWh) }\end{array}$ & $\begin{array}{l}\text { Post } \\
\text { (kBa/ } \\
\text { kWh) }\end{array}$ \\
\hline \multirow[t]{2}{*}{ MdA A } & G025 & NJ & 18 & 1372 & HD & all gas & 161.3 & 140.0 & 117.8 & 89.6 & 117.8 & 102.2 & 86.0 & 65.3 \\
\hline & & & & & & & & & eff. & $65 \%$ & 76.6 & 66.4 & 55.9 & 42.5 \\
\hline \multirow[t]{2}{*}{ MdA B } & G005/ & NY/ & 120 & 1655 & HD & all gas & 141 & 119 & 92.4 & 72.8 & 90.2 & 77.0 & 58.9 & 47.6 \\
\hline & G026 & NJ & & & & & & & eff. & $65 \%$ & 58.6 & 50.0 & 38.3 & 30.9 \\
\hline \multirow[t]{2}{*}{ ENC A } & G055 & MI & 57 & 1231 & fum & $\mathrm{sp} \mathrm{ht}$ & & & 118.0 & 105.5 & & & 98.4 & 87.5 \\
\hline & & & & & & & & & eff. & $65 \%$ & & & 64.0 & 56.9 \\
\hline \multirow[t]{2}{*}{ ENC B } & G055 & MI & 24 & 1137 & furn & sp ht & & & 117.4 & 119.3 & & & 103.3 & 105.0 \\
\hline & & & & & & & & & eff. & $65 \%$ & & & 67.1 & 68.2 \\
\hline \multirow[t]{2}{*}{ WNCA } & $G 052$ & $\mathbf{M N}$ & 21 & 1210 & frepl/ & all gas & 154.0 & 134.4 & & & 127.2 & 111.0 & & \\
\hline & & & & & wins & & & & eff. & $65 \%$ & 82.7 & 72.1 & & \\
\hline \multirow[t]{2}{*}{$\operatorname{Min} B$} & G029 & $\mathrm{CO}$ & 24 & 2488 & & all gas & 127.1 & 100.9 & 95.9 & 71.0 & 51.1 & 40.6 & 38.5 & 28.5 \\
\hline & & & & & & & & & eff. & $65 \%$ & 33.2 & 26.4 & 25.1 & 18.5 \\
\hline \multirow[t]{2}{*}{$\mathrm{PaN} A$} & 026 & OR & 92 & 1144 & burnr & sp ht & & & 89.7 & 68 & & & 78.4 & 59.4 \\
\hline & & & & & & & & & eff. & $65 \%$ & & & 51.0 & 38.6 \\
\hline \multirow[t]{2}{*}{$\mathrm{PaN} B$} & E011/ & $N W$ & 940 & 1650 & audit & all elec & 26345 & 22778 & 13295 & 9801 & 16.0 & 13.8 & 8.1 & 5.9 \\
\hline & E030 & & & & & & & & eff. & 3.413 & 54.5 & 47.2 & 27.5 & 20.3 \\
\hline \multirow[t]{2}{*}{$\mathrm{PaS} \quad \mathrm{B}$} & G027 & $\mathrm{CA}$ & 19 & 2322 & audit & all gas & & & 130.2 & 114.5 & & & 56.2 & 49.4 \\
\hline & & & & & & & & & eff. & $65 \%$ & & & 36.5 & 32.1 \\
\hline
\end{tabular}


Figure 16. Fuel Space and Water Heat

Prototype A,A1 Comparison with RECS Data

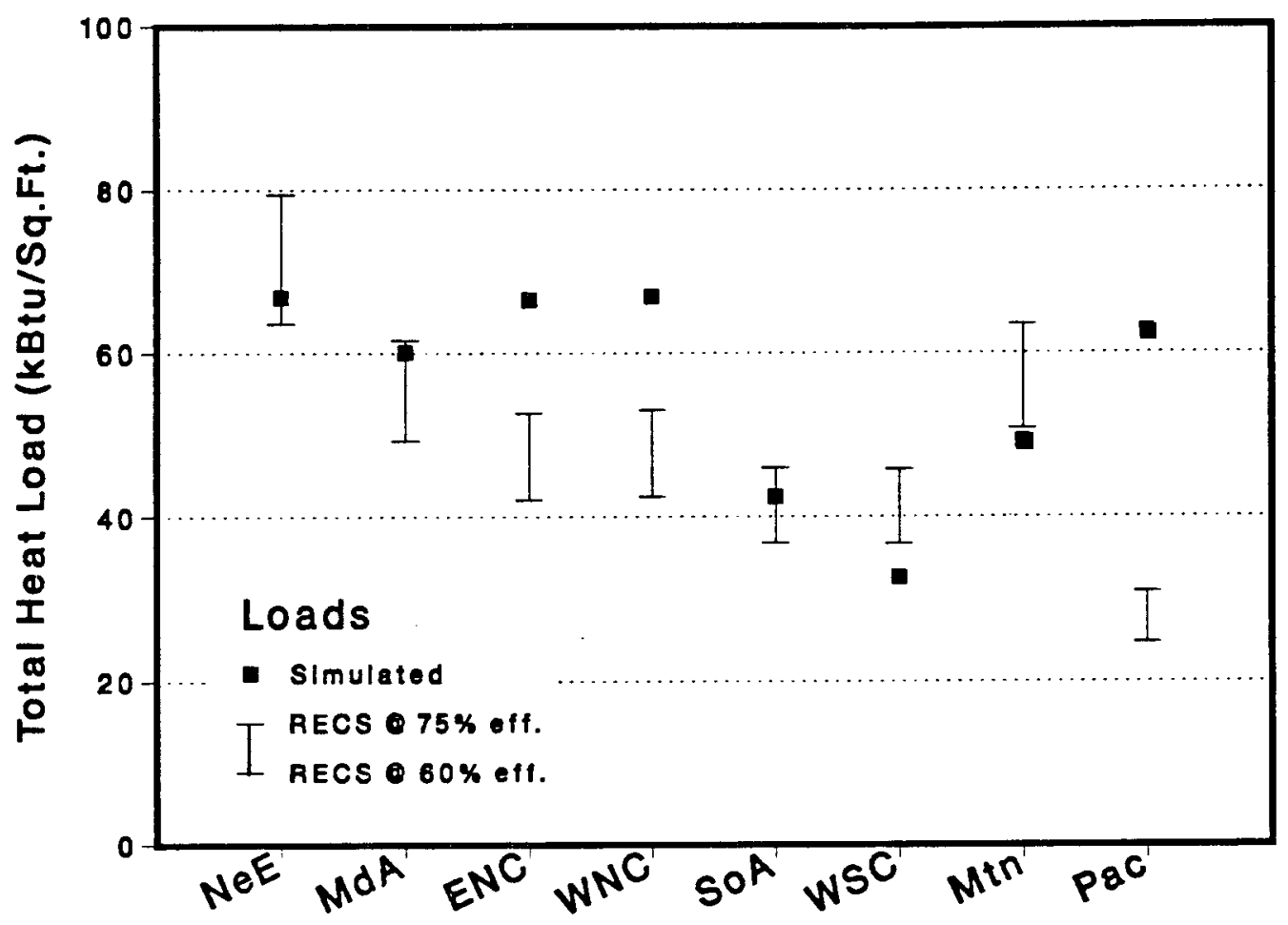

Figure 17. Fuel Space and Water Heat

Prototype B,B1 Comparison with RECS Data

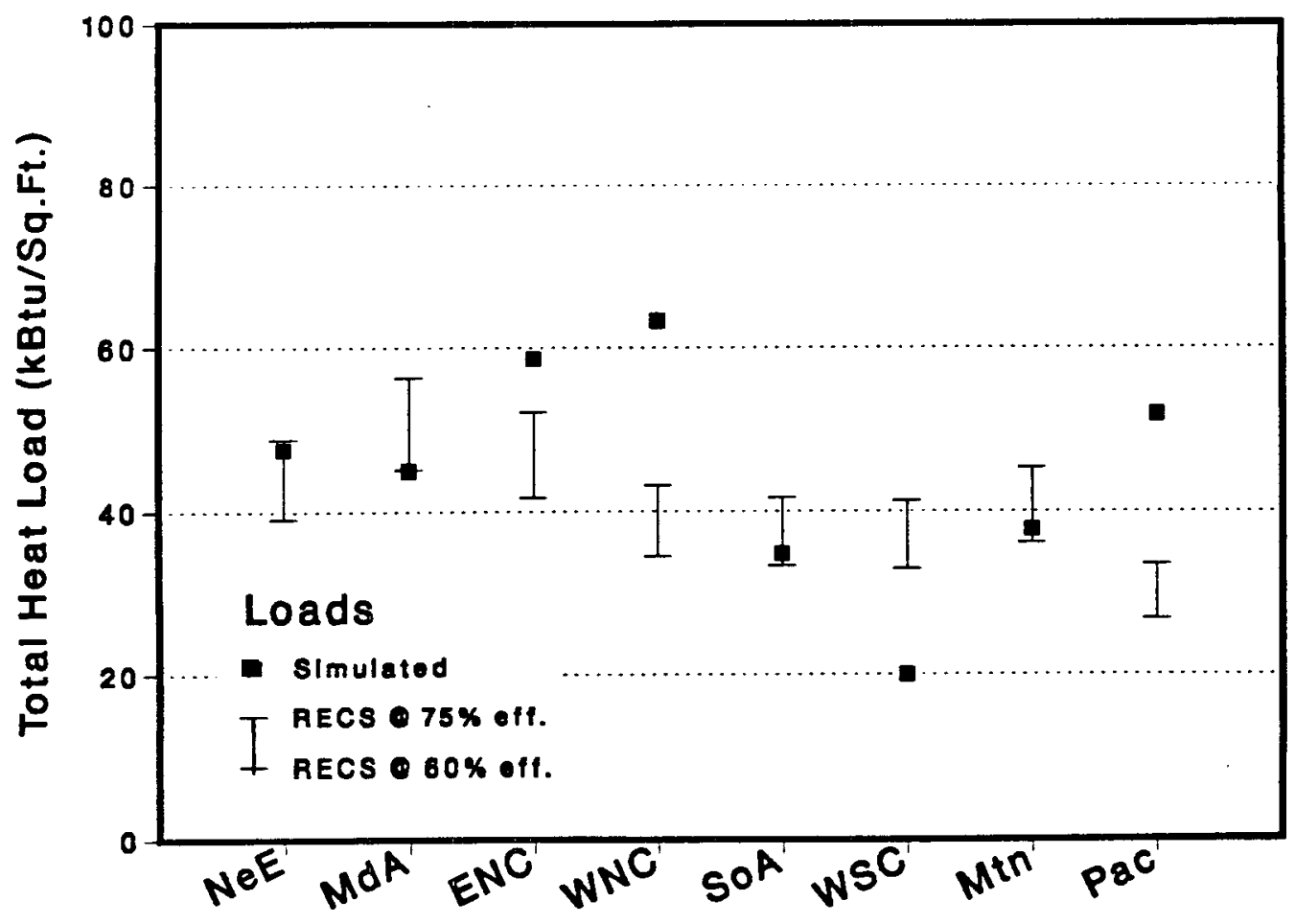


Figure 18. Fuel Space and Water Heat Prototype C Comparison with RECS Data

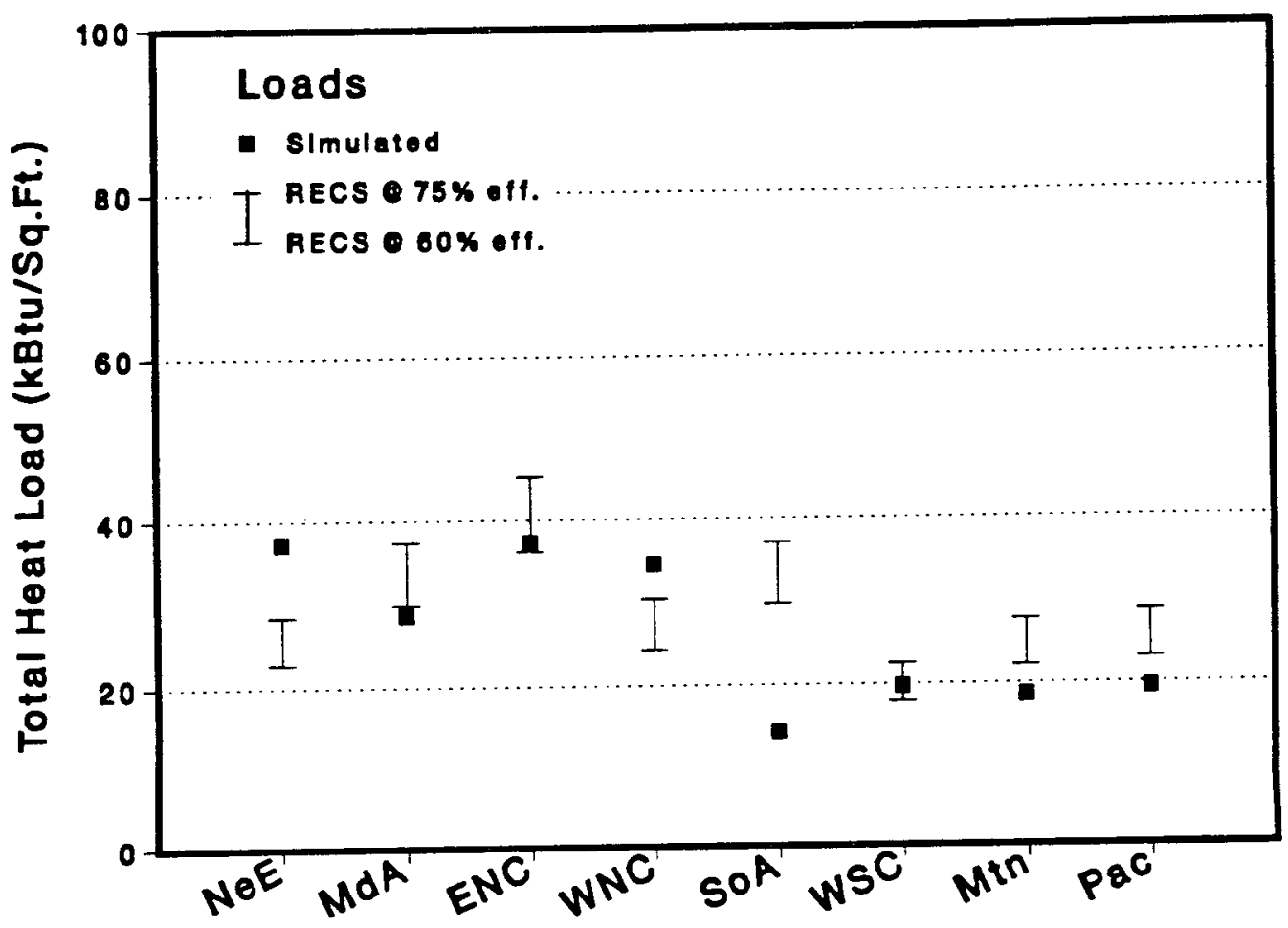

Figure 19. Electric Space Cooling

Various Prototypes, Comparlson with RECS Data

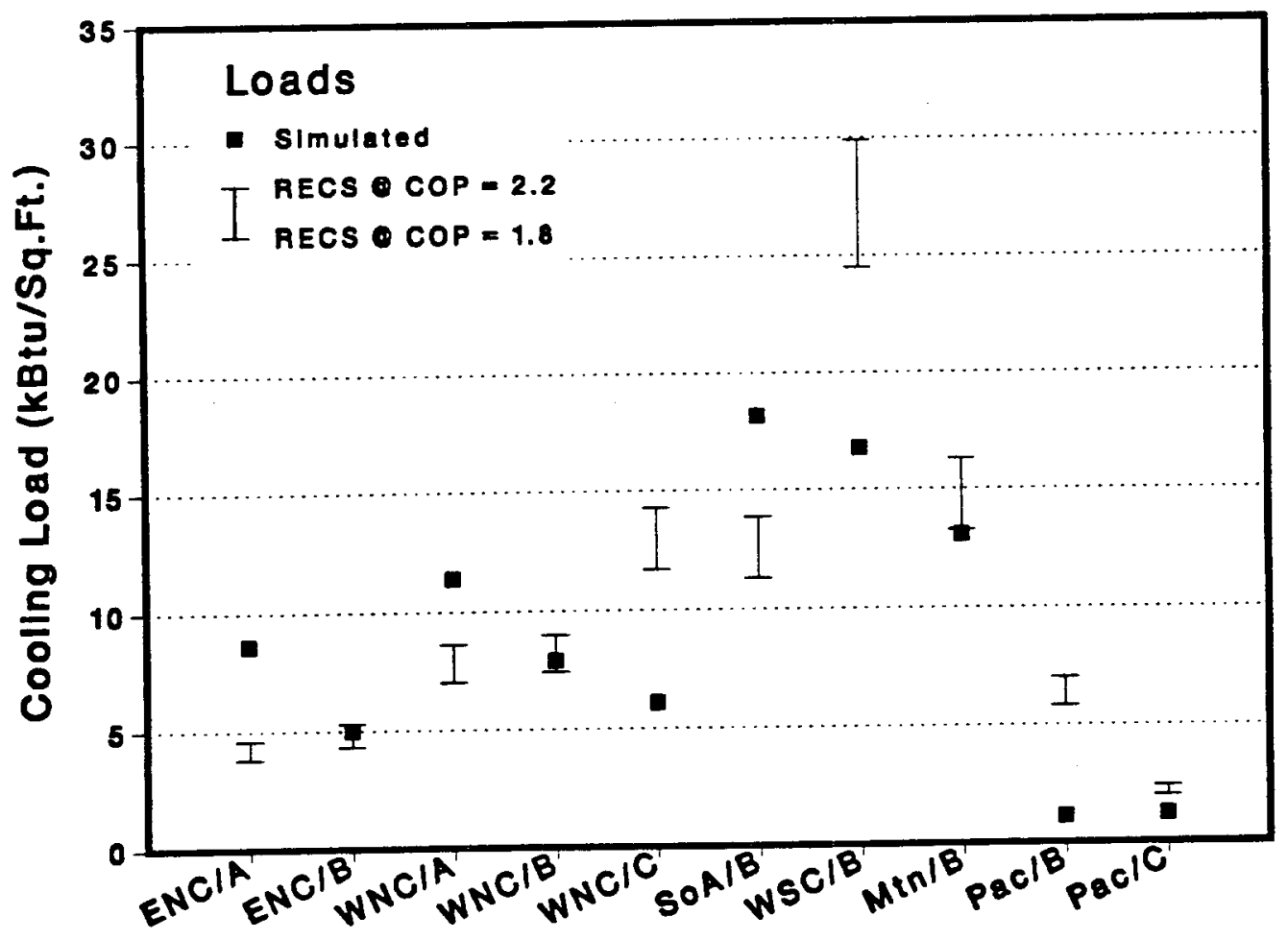


The second issue is that compared to the RECS data, the simulated loads slightly underestimate heating loads in the West South Central census divisions for the A and B prototypes. Once again, the RECS data give counter-intuitive results for these locations, since these locations are some of the warmest in the U.S. yet the RECS loads are similar to other climates.

$A$ third issue is that heating loads for the Pacific census division are somewhat higher for the $A$ and $B$ prototypes compared to both the RECS and, to a lesser extent, the BECA data. The agreement with RECS data for the $C$ prototype, however, is quite good. This disagreement is partly due to the RECS data, which shows extremely low use for the A prototypes. It is also difficult to compare building loads from the wide variety of climates in the Pacific census division. For example, the RECS fuel heating loads may be dominated by buildings in the Los Angeles climate, while the comparison includes both San Francisco and Los Angeles in the southern part of the region. Furthermore, in these locations the moderate climates produce mild, yet long heating seasons (see San Francisco in Figure 7 for example). Increased thermal integrity quickly reduces the annual heating load, which may explain why the prototype $\mathrm{C}$ loads are more comparable to the RECS data.

The comparison of cooling loads with the RECS data is difficult to assess, yet it is apparent that the DOE-2 simulated loads are not consistently high or low. The small number of cooling data points in the RECS data made this comparison difficult. We made no distinction between central air-conditioning or room air-conditioning (which may cool only a portion of the building) in the RECS data, while in the simulations we modeled full house cooling loads. This may account for some of the differences.

Based on this preliminary comparison the simulated loads appear to give reasonable estimates of heating, and to a lesser extent cooling, loads in the range of single-family buildings and climate types in the U.S. In a previous comparison of simulated and surveyed loads in multifamily buildings, it was noted that the typical customers surveyed were from the northern, colder climates. 5 Therefore, we would expect the greatest difference in these comparisons to occur in the southern locations. Finally, we contend that the comparison was adequate and that the building load data are reasonable and useful for future assessments of different equipment options. 
Figure 20. Space and Water Heat

Various Prototypes, Comparison with BECA Data

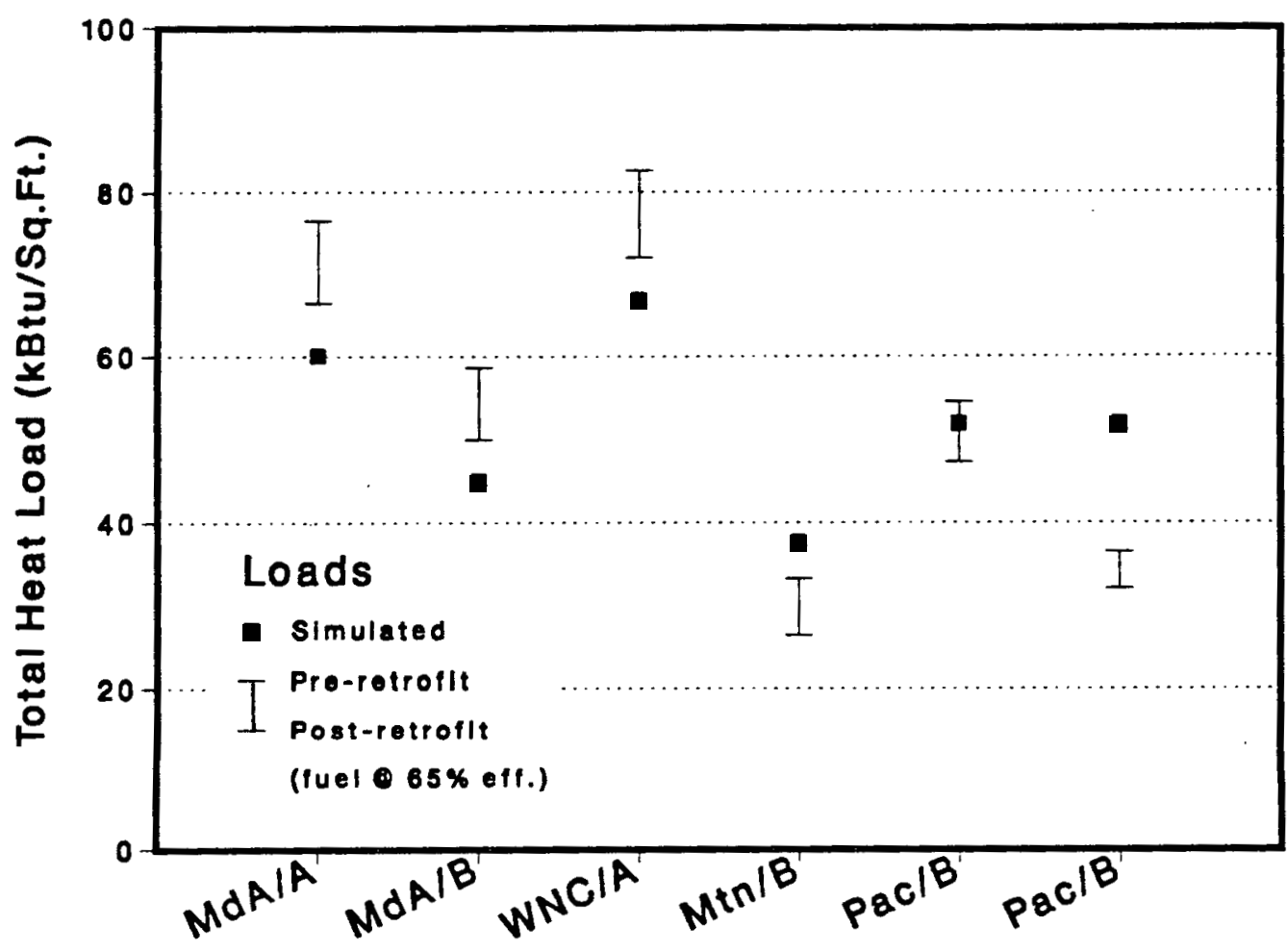

Figure 21. Space Heat Only

Various Prototypes, Comparison with BECA Data

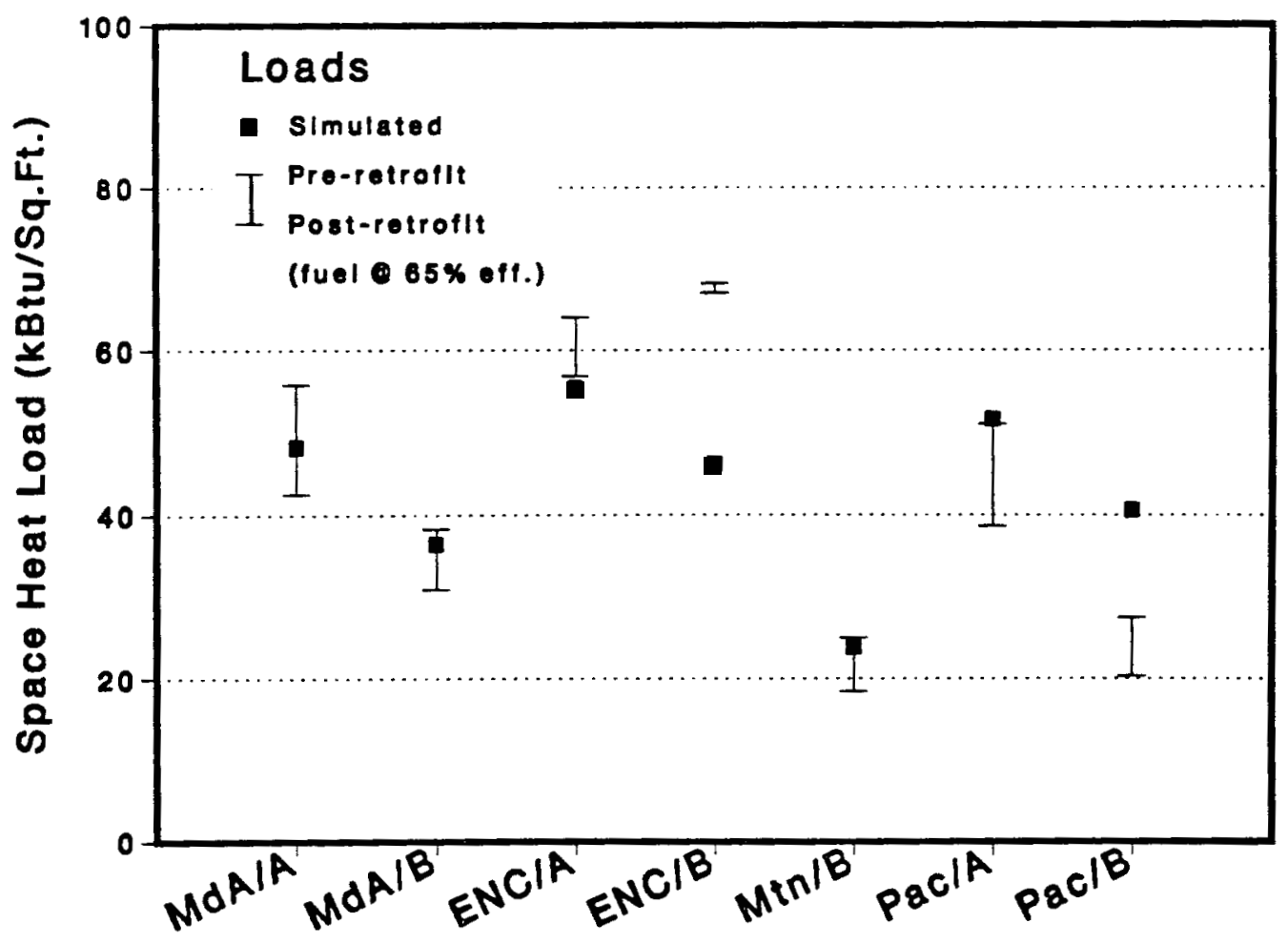




\section{REFERENCES}

1. Bluestein, J. and H. DeLima. Regional Characteristics and Heating/Cooling Requirements for Single-family Detached Houses. Topical Report No. GRI-85/164, Gas Research Institute, Chicago, IL.

2. Barnes, J., J. Bluestein and H. Bernstein 1986. Overview of the United States Residential Multifamily Housing Sector. Topical Report No. GRI-86/0060, Gas Research Institute, Chicago, IL.

3. Crawley, D.B., and Briggs, R.S. 1989. Building Energy Requirements Data Base Guidebook for Office Buildings. Topical Report No. GRI-89/0029, Gas Research Institute, Chicago, IL.

4. Ritschard, R. L. and Y.J. Huang 1989. Multifamily Heating and Cooling Requirements: Assumptions, Methods, and Summary Results. Topical Report No. GRI-88/0239, Gas Research Institute, Chicago, IL.

5. Ritschard, R. L. and J. W. Hanford 1989. Comparison of Multifamily Heating and Cooling Loads from DOE-2 Simulations to Measured Data. Topical Report No. GRI89/0163, Gas Research Institute, Chicago, IL.

6. Huang, Y.J., R. Ritschard, J. Bull, S. Byme, I. Turiel, D. Wilson, C. Hsui and D. Foley, 1987. Methodology and Assumptions for Evaluating Heating and Cooling Energy Requirements in New Single-family Residential Buildings. Tecbnical Support Document for the PEAR Microcomputer Program. Lawrence Berkeley Laboratory Report No. LBL-19128, Berkeley, CA.

7. Huang, Y. J., R. Ritschard and J. Bull 1987. Technical Documentation for a Residential Energy Use Data Base Developed in Support of ASHRAE Special Project 53. Lawrence Berkeley Laboratory Report No. LBL-24306, Berkeley, CA.

8. U. S. Department of Energy 1985. Proposed Interim Energy Conservation Standard for Federal Residential Buildings-Technical Support Document. Washington, D.C.

9. Energy Information Administration, 1987. Residential Energy Consumption Survey (RECS). U.S. Department of Energy, Washington, D.C.

10. NAHB National Research Center, 1989. 1987 Builder Practices Survey Data, prepared for Lawrence Berkeley Laboratory, P.O. No. 4556710, March 1, 1989.

11. ASHRAE 1990. ASHRAE Standard: Energy Efficient Design of New Low-rise Residential Buildings (BSR/ASHRAE 90.2p), Public Review Draft. American Society of Heating, Refrigerating, and Air-conditioning Engineers, Inc., Atlanta, GA. 
12. National Appliance Energy Conservation Act of 1987 (P.L. 100-12) and National Appliance Energy Conservation Amendments of 1988 (P.L. 100-357), Washington, DC.

13. Ritschard, R. L., J. W. Hanford, and A. O. Sezgen 1992. Analysis of Energy Conservation Codes in Single-family Homes. GRI Report No. GRI-91/0158, Gas Research Institute, Chicago, IL.

14. Andersson, B., W. L. Carroll, and M. R. Martin 1986. Aggregation of U. S. Population Centers Using Climate Parameters Related to Building Energy Use. Journal of Climate and Applied Meteorology, Vol. 25, No. 5, May 1986.

15. Crow, L., 1984. Weather Year for Energy Calculations. ASHRAE Journal 16 (6): $42-47$.

16. 12. U. S. Department of Commerce, Bureau of the Census, 1980-1989. Characteristics of New Housing: 1980-1989. Current Construction Reports, Series C25.

17. Doug Poutasse, F.W. DODGE corporation, personal communication with Joe Huang, LBL, May 14, 1990 (Construction projections, 1991-2000)

18. Doug Poutasse, F.W. DODGE corporation, personal communication with Joe Huang, June 8, 1990 (Square footage per dwelling unit, 1971-1990).

19. NAHB Research Foundation, Inc. n.d. Special NAHB Research Foundation Report. Upper Marlboro, MD.

20. National Association of Home Builders, personal communication with Ken Kazmer, Gas Research Institute, September 21, 1990.

21. Albrand, P., I. Turiel, R. Ritschard and D. Wilson, 1985. Low Rise Multifamily Housing: A Preliminary Survey of Building Characteristics and Prototype Development. Lawrence Berkeley Laboratory Report 20229, Berkeley, CA.

22. Turiel, I., R. Ritschard, D. Wilson and P. Albrand, 1985. Low Rise Multifamily Housing: Prototype Development and Preliminary Energy Analysis. Lawrence Berkeley Laboratory Report 18823, Berkeley, CA.

23. Sherman, M.H. and D.T. Grimsrud, 1980. Measurement of Infiltration Using Fan Pressurization and Weather Data. Lawrence Berkeley Laboratory Report 10892, Berkeley, CA.

24. Sherman, M.H, D.J. Wilson, and D.E. Kiel, 1984. Variability in Residential Air Leakage. Lawrence Berkeley Laboratory Report 17587, Berkeley, CA.

25. American Society of Heating, Refrigeration and Air-conditioning Engineers (ASHRAE), 1988. Air Leakage Performance for Detached Single-Family Residential Buildings, ANSI/ASHRAE 119-1988, Atlanta, GA.

26. Labs, K., J. Carmondy, R. Sterling, L. Shen, Y.J. Huang, and D. Parker, 1988. Building Foundation Design Handbook, Oak Ridge National Laboratory Report, ORNL/Sub/8672143/1., Oak Ridge, TN. 
27. Fels, M.F. and M.L. Goldberg, 1984. With Just Billing and Weather Data, Can One Separate Lower Thermostat Settings from Extra Insulation? In: Families and Energy, (Eds.) B. Morrison and W. Kempton, Institute for Family and Child Study, Michigan State University, East Lansing, MI.

28. Kempton, W. and S. Krabacher, 1987. Thermostat Management: Intensive Interviewing Used to Interpret Instrumentation Data. In: Energy Efficiency: Perspectives on Individual Behavior, (Eds.) W. Kempton and M. Neiman, American Council for an EnergyEfficient Economy, Washington, DC.

29. Vine, E., 1986. Saving Energy the Easy Way: An Analysis of Thermostat Management. Energy 11 (10): 977-984.

30. American Society of Heating, Refrigeration and Air-conditioning Engineers (ASHRAE), 1981. ASHRAE Handbook of Fundamentals, Atlanta, GA.

31. Energy Information Administration, 1989. Household Energy Consumption and Expenditures 1987, Part 1: National Data. U.S. Department of Energy, Washington, D.C.

32. McMahon, J.E. 1987. LBL Residential Energy Model: An Improved Policy Analysis Tool, Energy Systems and Policy, Vol. 10, No. 1, pp. 41-71.

33. Turiel, I., D. Berman, P. Chan, T. Chan, J. Koomey, B. Lebot, M. Levine, J. McMahon, G. Rosenquist, and S. Stoft. 1990. U.S. Residential Appliance Energy Efficiency: Present Status and Future Directions. Proceedings of the American Council for an Energy Efficient Economy (ACEEE) 1990 Summer Study on Energy Efficiency in Buildings, Asilomar, CA.

34. California Energy Commission, 1980. Assumptions Used with Energy Performance Computer Programs, Project Report No. 7. California Energy Commission, Sacramento, CA.

35. California Energy Commission, 1985. Methodology for Calculating Water Heating Energy Pursuant to the Residential Building Standard (Staff Report). California Energy Commission, Sacramento, CA.

36. U.S. Department of Energy 1985. Code of Federal Regulations, 10: Part 430 (Energy Conservation Program for Consumer Products), pp. 58-65.

37. American Society of Heating, Refrigeration and Air-conditioning Engineers (ASHRAE), 1987. Service Water Heating, Chapter 54. Handbook of HVAC Systems and Applications, Atlanta, GA.

38. Thrasher, W.H., D.W. DeWerth, and B.R. Becker 1990. Comparison of Collected and Compiled Existing Data on Service Hot Water Use Patterns in Residential and Commercial Establishments; Phase 1 Final Report. ASHRAE research project no. 600-RP, Atlanta, GA. 
39. Taylor, H., and F. Force. 1987. "Patterns of domestic hot water consumption for a multifamily building." Proceedings of the ACEEE 1988 Summer Study, American Council for an Energy-Efficient Economy, Washington, DC.

40. Perlman, M., B.E. Mills and B.T. Barber, 1984. Development of Residential Hot Water Use Patterns. Prepared for American Society of Heating, Refrigerating and Airconditioning Engineers, Inc., by Ontario Hydro, Toronto, Canada.

41. Brown, M., D. White, and S. Purucker, 1987. Impact of the Hood River Conservation Project on Electric Use for Residential Water Heating. Oak Ridge National Laboratory Report CON-238, Oak Ridge, TN.

42. Cohen, S., C. Goldman and J. Harris, 1991. Measured Energy Savings and Economics of Retrofitting Existing Single-Family Homes: An Update of the BECA-B Database. Lawrence Berkeley Laboratory Report No. LBL-28147, Vols. I and II, Berkeley, CA. 
INPUT DEVELOPMENT AND SENSITIVITIES 


\section{APPENDIX A: SAMPLE REPRESENTATION OF PROTOTYPES}

The table which follows gives the distribution of single-family detached building stock by vintage and census division, and the portions of that stock which are represented by the prototype buildings in the single-family database. Because of the large number of prototypes (55) and the even larger number of prototype/climate combinations (80), the numbers have been consolidated to the level of census division. These numbers are updated versions of the figures in the previous single-family database report based on 1) updated $\mathrm{B} 1+$ and $\mathrm{C}$ prototype descriptions, 2) the new distribution of base cities, 3) new estimates of building populations from more current data sources, and 4) a slightly different method of determining representativeness.

The stock populations for pre-1980s buildings in each census division were derived from the 1984 RECS database. Stock populations for 1980 s buildings were derived from Census Bureau data for the period 1980-1989, which contain single-family detached building construction by census region. This stock was broken down to census division level using data from NAHB which report single family housing starts by state.

The method used to determine the level of representation for each of the prototypes was to follow the same method used in determining prototype characteristics. However, the level of detail in the prototype buildings represents a combination of building characteristics which would be found in few actual buildings. Therefore, in determining representation we used major building characteristics which would be important in creating unique building energy use profiles. Thus, the calculation is somewhat arbitrary, since if more building characteristics are used to evaluate the representation of the sample by the prototype, the less "representative" the prototype becomes.

The primary data sources, both the 1984 RECS for the pre-1980s prototypes and the 1987 NAHB Builders Survey for the 1980 s prototypes, were cross-referenced to five major criteria which directly affect building construction and thus building energy use: 1) building vintage, 2) census division, 3) construction type (one story, two story, or other), 4) ceiling insulation, and 5) window glazing layers. Ceiling insulation and window layers were considered to be proxies for overall building thermal integrity. Within each vintage and census division, the data provided factors for percentage of buildings with similar characteristics to the prototype descriptions. These factors were then applied to the stock populations to determine the number 
represented by each prototype.

For the B1+ prototypes, size was assumed to be the determining factor, so the B1+ prototype distributions are based only on vintage, census division, construction type, and the number of buildings with conditioned square footage equal to or greater than the prototype square footage (defined as the mean plus two standard deviations).

Overall, the level of representation is similar to the numbers provided in the previous report. Thirty-five percent of the total housing stock is represented by the prototype descriptions. The range within census divisions is from over 50\% in New England and South Pacific to about $20 \%$ in the West South Central and North Pacific. The lower numbers refiect a greater variability in building characteristics and thus a less immediately characterizable population. In terms of prototypes, the $C$ prototypes represent almost $40 \%$ of the 1980 s building population, while $45 \%$ and $51 \%$ of the pre-1940 and $1950-1969$ populations are represented, respectively. 
ESTIMATES OF SINGLE FAMILY DETACHED HOUSE POPULATION (THOUSANDS)

\begin{tabular}{|c|c|c|c|c|c|c|c|c|c|c|c|}
\hline & $\begin{array}{c}\text { NEW } \\
\text { ENGLAND }\end{array}$ & $\begin{array}{c}\text { MID } \\
\text { ATLANTIC }\end{array}$ & $\begin{array}{l}\text { E NORTH } \\
\text { CENTRAL }\end{array}$ & $\begin{array}{l}\text { W NORTH } \\
\text { CENTRAL }\end{array}$ & $\begin{array}{c}\text { SOUTH } \\
\text { ATLANTIC }\end{array}$ & $\begin{array}{l}\text { E SOUTH } \\
\text { CENTRAL }\end{array}$ & $\begin{array}{l}\text { W SOUTH } \\
\text { CENTRAL }\end{array}$ & MOUNTAIN & $\begin{array}{c}\text { NORTH } \\
\text { PACIFIC }\end{array}$ & $\begin{array}{l}\text { SOUTH } \\
\text { PACIFIC }\end{array}$ & $\begin{array}{c}\text { TOTAL } \\
\text { VINTAGE }\end{array}$ \\
\hline BEFORE 1940 & 988 & 2549 & 4296 & 1706 & 2124 & 942 & 1470 & 498 & 621 & 792 & 15986 \\
\hline Prototype A & 235 & 527 & 596 & 203 & 302 & 186 & 106 & 60 & 47 & 348 & 2610 \\
\hline Prototype A1 & 454 & 1050 & 1431 & 598 & 379 & 173 & 46 & 129 & 101 & 227 & 4588 \\
\hline 1940 to 1949 & 157 & 438 & 980 & 317 & 1210 & 293 & 738 & 219 & 248 & 502 & 5102 \\
\hline 1950 to 1969 & 965 & 2255 & 2279 & 1377 & 4188 & 1634 & 2706 & 1097 & 845 & 2394 & 19740 \\
\hline Prototype B & 93 & 184 & 291 & 186 & 533 & 228 & 270 & 81 & 57 & 722 & 2645 \\
\hline Prototype B1 & 417 & 606 & 1526 & 943 & 847 & 173 & 454 & 239 & 197 & 1301 & 6703 \\
\hline Prototype B1+ & 16 & 46 & 26 & 120 & 111 & 78 & 137 & 99 & 39 & 111 & 783 \\
\hline 1970 to 1979 & 315 & 1090 & 1507 & 908 & 2055 & 1090 & 1256 & 793 & 496 & 423 & 9933 \\
\hline 1980 to 1989 & 486 & 846 & 1006 & 598 & 2715 & 487 & 1347 & 746 & 269 & 1193 & 9693 \\
\hline Prototype C & 279 & 436 & 442 & 175 & 1367 & 196 & 270 & 292 & 92 & 296 & 3845 \\
\hline TOTAL STOCK & 2911 & 7178 & 10068 & 4906 & 12292 & 4446 & 7517 & 3353 & 2479 & 5304 & 60454 \\
\hline Total Prototypes & 1494 & 2849 & 4312 & 2225 & 3539 & 1034 & 1283 & 900 & 533 & 3005 & 21174 \\
\hline Note: & $\begin{array}{l}\text { Pacific Divi } \\
\text { No cities in } \\
\text { ESC prototy }\end{array}$ & and clin & are ret & (h) & C & 1 & 5. & Cotunos & 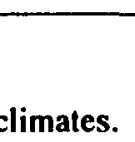 & & \\
\hline
\end{tabular}




\section{APPENDIX B: BUILDING SIZE ANALYSIS FOR 1980s/1990s HOUSE}

We analyzed several data sources in developing building size estimates for 1980 s construction and one data set projecting average size into the 1990s. Based on an analysis of these data, our conclusions were to derive average 1980 building size using weighted average floor areas from Census Bureau reports combined with 1987 NAHB builder survey data on construction type in the base cities. Furthermore, we concluded that the 1980 prototype house size should be increased by about 200 square feet to make the 1990 prototype. The analysis is summarized below.

\section{0s BUILDING SIZE DATA}

We gathered average square footage estimates for new single family construction between 1980 and 1989 from U.S Census Bureau reports, the National Association of Home Builders (NAHB), and the F.W. Dodge Corporation. The types of data are summarized as follows.

Census Bureau Reports. The Census reports give mean and median square foot data for new construction by census region and for the U.S. as a whole. They also tabulate construction type; one story, two story, and split-level. These data are shown in Table 1.

NAHB data. Average square footage data for new construction, 1979-1988, on both state and national level were provided to GRI by the NAHB. These data are shown in Table 2 . We also compiled floor area data from the NAHB 1987 Builders Survey. The predominant construction type and average square footage for that construction type are shown in Table 3 for each GRI base city. Where the average square footage given in the Builders Survey seemed unreasonable compared with the other cities, we combined square footage data from neighboring states to develop a better estimate.

DODGE data. We also obtained estimates of average new single-family construction square footage, 1971-1990, from the F.W. Dodge Corporation. These data were provided as national averages and by census division, and are given in Table 4 .

\section{Discussion}

Figure 1 , in the main body of the report, presents the various estimates for average floor area through the 1980s, including Census Bureau, Dodge, and NAHB data. While the magnitudes differ, the plot shows that on a national level, floor area is constant from 1980-85, and then rises at rates between 35 and 70 square feet per year. Tables 1, 2, and 4 show that this general trend has been true in all areas of the country. 
Table 1. Average Floor Area and Construction Type, 1980-89

US Bureau of Census, New Single Family Construction

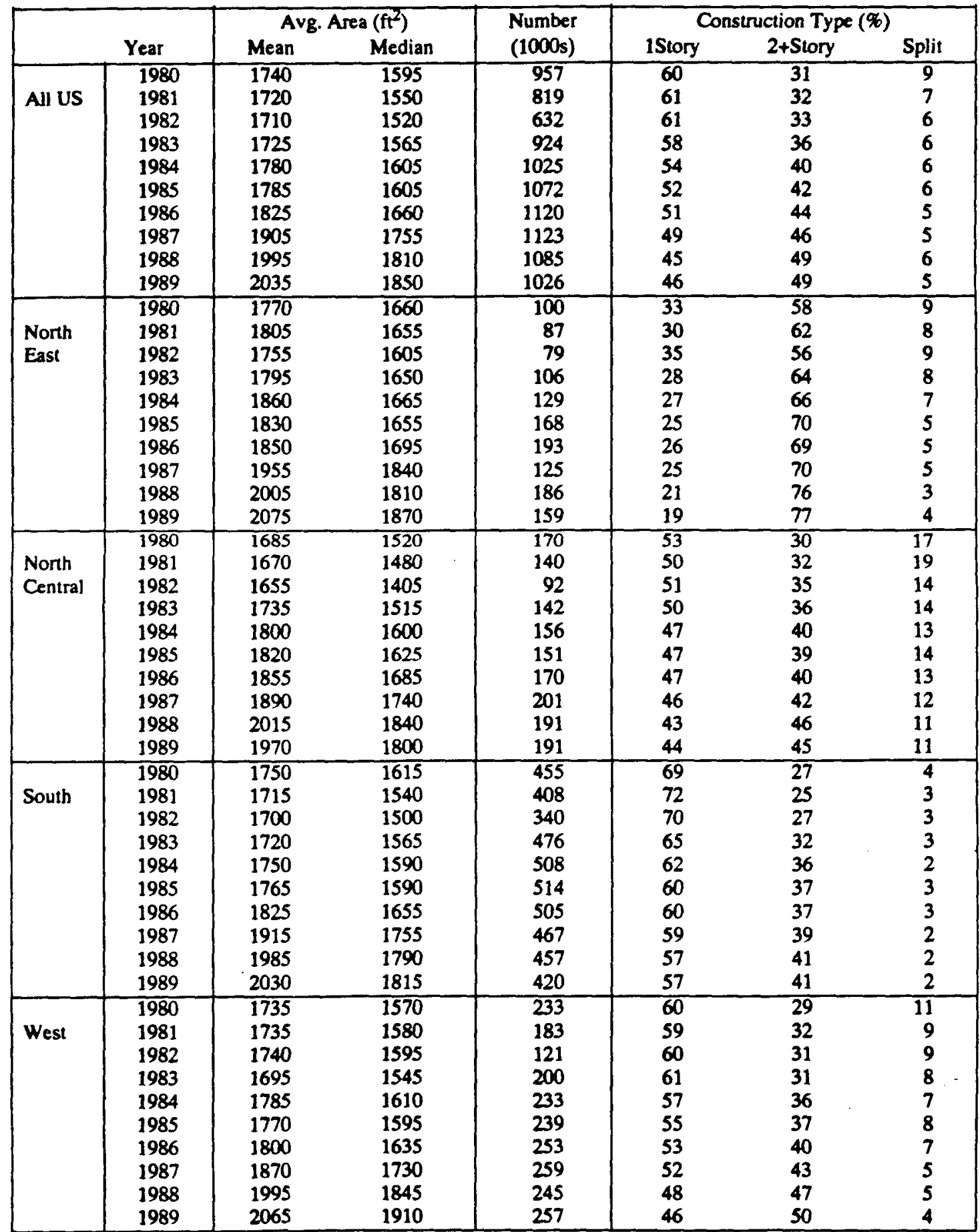

Source: U. S. Department of Commerce, Bureau of the Census, 1980-1989. Characteristics of New Housing: 1980-1989. Current Construction Reports, Series C25. 
Table 2. Average Floor Area by State, 1979-1988

NAHB, New Single Family Detached Construction

\begin{tabular}{|c|c|c|c|c|c|c|c|c|c|c|}
\hline STATE & 1979 & 1980 & 1981 & 1982 & 1983 & 1984 & 1985 & 1986 & 1987 & 1988 \\
\hline$\overline{C T}$ & 1990 & 2082 & 2246 & 2395 & 2123 & 2259 & 2340 & 2356 & 2634 & 2554 \\
\hline ME & 1273 & 1241 & 1256 & 1413 & 1465 & 1170 & 1596 & 1730 & 2336 & 2444 \\
\hline $\mathbf{M A}$ & 1754 & 1802 & 1839 & 1971 & 1912 & 1845 & 1926 & 2151 & 2513 & 2428 \\
\hline NH & 1620 & 1583 & 1678 & 1771 & 1493 & 1433 & 1728 & 1712 & 1775 & 2043 \\
\hline $\mathbf{R I}$ & 1815 & 1763 & 1689 & 1929 & 1950 & 1913 & 1350 & 2090 & 1830 & 2066 \\
\hline VT & 1513 & 1551 & 1690 & 1602 & 1527 & 1915 & 2027 & 1983 & 1982 & 2224 \\
\hline NJ & 1883 & 2012 & 2106 & 2131 & 1662 & 1936 & 1745 & 1851 & 2205 & 2462 \\
\hline NY & 2019 & 1907 & 1983 & 2041 & 1730 & 1743 & 2096 & 2058 & 2459 & 2184 \\
\hline PA & 1936 & 1748 & 1578 & 1575 & 1583 & 1381 & 1962 & 1929 & 2321 & 1994 \\
\hline IL & 1910 & 1861 & 1928 & 1861 & 1794 & 1968 & 2331 & 1952 & 2079 & 2110 \\
\hline IN & 1808 & 1546 & 1599 & 1668 & 1771 & 1551 & 1606 & 1588 & 2003 & 2066 \\
\hline MI & 1749 & 1839 & 1749 & 1852 & 1707 & 1708 & 1642 & 1596 & 1682 & 2008 \\
\hline $\mathrm{OH}$ & 1816 & 1879 & 1887 & 1595 & 1890 & 1955 & 2101 & 2083 & 2217 & 2246 \\
\hline WI & 1587 & 1451 & 1527 & 1439 & 1451 & 1578 & 1446 & 1778 & 1739 & 1927 \\
\hline IA & 1572 & 1618 & 1586 & 1368 & 1443 & 1748 & 1615 & 1750 & 2000 & 2116 \\
\hline KS & 1989 & 1910 & 1763 & 1893 & 1756 & 1604 & 1860 & 1904 & 1923 & 2261 \\
\hline $\mathbf{M N}$ & 1611 & 1718 & 1742 & 1725 & 1398 & 1521 & 1834 & 1765 & 1859 & 2574 \\
\hline MO & 1697 & 1662 & 1606 & 1670 & 1827 & 1906 & 1750 & 1724 & 2010 & 2091 \\
\hline NB & 1432 & 6283 & 1689 & 1798 & 1648 & 1504 & 1615 & 1889 & 1789 & 1728 \\
\hline ND & 1904 & 1693 & 1280 & 1133 & 1172 & 1400 & 1650 & 1700 & 1850 & 1796 \\
\hline SD & 1250 & 1250 & 1255 & 2043 & 1728 & 1321 & 1371 & 1450 & 1600 & 1603 \\
\hline DE & 1592 & 1673 & 1634 & 1811 & 2563 & 1554 & 1549 & 1700 & 1734 & 1951 \\
\hline FL & 1573 & 1491 & 1525 & 1465 & 1432 & 1501 & 1455 & 1684 & 1855 & 1705 \\
\hline GA & 1913 & 1730 & 1681 & 1723 & 1641 & 1600 & 1726 & 1877 & 2294 & 1968 \\
\hline MD & 2077 & 2028 & 2013 & 1823 & 1777 & 2047 & 2107 & 2209 & 2274 & 2078 \\
\hline NC & 1646 & 1564 & 1544 & 1573 & 1605 & 1703 & 1692 & 1778 & 2010 & 1812 \\
\hline SC & 1693 & 1586 & 1599 & 1724 & 1426 & 1409 & 1423 & 1580 & 1782 & 1926 \\
\hline VA & 1805 & 1876 & 1939 & 1845 & 1780 & 1969 & 1915 & 2225 & 2010 & 2400 \\
\hline WV & 1411 & 1838 & 1679 & 1162 & 1441 & 1940 & 1870 & 1267 & 1377 & 1612 \\
\hline AL & 1552 & 1562 & 1431 & 1487 & 1546 & 1744 & 1681 & 1660 & 2109 & 1779 \\
\hline KY & 1659 & 1719 & 1649 & 1461 & 1488 & 1592 & 1454 & 1637 & 1767 & 2096 \\
\hline MS & 1435 & 1488 & 1334 & 1636 & 1638 & 1700 & 1339 & 1875 & 1775 & 1394 \\
\hline TN & 1548 & 1526 & 1671 & 1728 & 1790 & 1869 & 1963 & 1697 & 1877 & 2172 \\
\hline AR & 1419 & 1471 & 1517 & 1547 & 1400 & 1830 & 1398 & 1446 & 1879 & 1487 \\
\hline LA & 1791 & 1668 & 1662 & 1545 & 1611 & 1666 & 1837 & 1806 & 1890 & 2260 \\
\hline OK & 1657 & 1644 & 1586 & 1716 & 1477 & 1567 & 1707 & 1800 & 1837 & 2098 \\
\hline TX & 1692 & 1716 & 1608 & 1694 & 1622 & 1665 & 1675 & 1686 & 2215 & 2175 \\
\hline $\mathbf{A Z}$ & 1547 & 1515 & 1583 & 1594 & 1549 & 1554 & 1637 & 1798 & 1648 & 1952 \\
\hline $\mathrm{CO}$ & 1704 & 1785 & 1581 & 1410 & 1486 & 1766 & 1713 & 1786 & 1746 & 2100 \\
\hline ID & 1602 & 1557 & 1562 & 1519 & 1453 & 1636 & 1731 & 1800 & 1820 & 2102 \\
\hline MT & 1356 & 1289 & 1253 & 1248 & 1728 & 1577 & 1522 & 1883 & 1700 & 2738 \\
\hline NV & 1516 & 1676 & 1541 & 1731 & 1662 & 1601 & 1534 & 1726 & 1692 & 1738 \\
\hline NM & 1645 & 1437 & 1371 & 1662 & 1268 & 1377 & 1594 & 1487 & 1642 & 1865 \\
\hline UT & 1467 & 1465 & 1519 & 1607 & 1522 & 1187 & 1665 & 1815 & 1695 & 1804 \\
\hline WY & 1710 & 1600 & 1651 & 1542 & 1466 & 1498 & 1694 & 1501 & 1480 & 1377 \\
\hline CA & 1856 & 1956 & 1887 & 1738 & 1737 & 1684 & 1690 & 1801 & 1935 & 2166 \\
\hline OR & 1642 & 1548 & 1587 & 1505 & 1495 & 1515 & 1612 & 1614 & 1854 & 2049 \\
\hline WA & 1712 & 1815 & 1728 & 1461 & 1754 & 1646 & 1633 & 1472 & 1832 & 1988 \\
\hline US & 1714 & 1700 & 1702 & 1679 & 1635 & 1684 & 1752 & 1837 & 2019 & 2065 \\
\hline
\end{tabular}

Source: Unpublished data. National Association of Home Builders, personal communication with Ken Kazmer, Gas

Research Institute, Sept. 21, 1990. 
Table 3. Predominant Construction Type and Average Floor Area for Base Cities Calculated from NAHB Builder Survey Data, 1987

\begin{tabular}{|lccc|lccc|}
\hline City & State & $\begin{array}{c}\text { Number } \\
\text { Stories }\end{array}$ & $\begin{array}{c}\text { Area } \\
\left(\mathrm{ft}^{2}\right)\end{array}$ & City & State & $\begin{array}{r}\text { Number } \\
\text { Stories }\end{array}$ & $\begin{array}{r}\text { Area } \\
\left(\mathrm{ft}^{2}\right)\end{array}$ \\
\hline Boston & MA & 2 & 2450 & New Orleans & LA & 1 & 1690 \\
New York & NY & 2 & 2450 & Fort Worth & TX & 1 & 1790 \\
Chicago & IL & 2 & 2230 & Denver & CO & 2 & 2030 \\
Minneapolis & MN & 2 & 2220 & Albuquerque & NM & 1 & 1590 \\
Kansas City & MO & 2 & 2290 & Phoenix & AZ & 1 & 1590 \\
Washington & DC & 2 & 2300 & Seattle & WA & 2 & 2120 \\
Atlanta & GA & 2 & 2400 & San Francisco & CA & 2 & 2020 \\
Miami & FL & 1 & 1790 & Los Angeles & CA & 2 & 2020 \\
\hline
\end{tabular}

Source: Calculated from NAHB National Research Center, 1989. 1987 Builder Practices Survey Data, prepared for Lawrence Berkeley Laboratory, P.O. No. 4556710, March 1, 1989.

Table 4. Average Floor Area by Census Division, 1980-1989

F.W. Dodge Corporation Data, New Single Family Construction

\begin{tabular}{|l|l|llllllllll|}
\hline Year & US & NENG & MATL & ENC & WNC & SATL & ESC & WSC & PNW & PSW \\
\hline 1980 & 1587 & 1538 & 1522 & 1559 & 1537 & 1596 & 1487 & 1678 & 1493 & 1641 \\
1981 & 1600 & 1552 & 1525 & 1560 & 1534 & 1604 & 1534 & 1605 & 1535 & 1730 \\
1982 & 1564 & 1546 & 1539 & 1554 & 1556 & 1559 & 1517 & 1596 & 1496 & 1596 \\
1983 & 1576 & 1559 & 1552 & 1570 & 1565 & 1570 & 1531 & 1596 & 1573 & 1604 \\
1984 & 1577 & 1561 & 1563 & 1563 & 1535 & 1575 & 1560 & 1618 & 1533 & 1592 \\
1985 & 1565 & 1590 & 1558 & 1571 & 1519 & 1572 & 1542 & 1569 & 1559 & 1569 \\
1986 & 1600 & 1635 & 1610 & 1559 & 1561 & 1620 & 1605 & 1570 & 1595 & 1584 \\
1987 & 1659 & 1665 & 1677 & 1656 & 1633 & 1669 & 1649 & 1604 & 1618 & 1675 \\
1988 & 1686 & 1681 & 1694 & 1673 & 1653 & 1691 & 1652 & 1642 & 1664 & 1718 \\
1989 & 1729 & 1690 & 1726 & 1763 & 1670 & 1725 & 1633 & 1643 & 1747 & 1785 \\
\hline
\end{tabular}

Source: Unpublished data. Doug Poutasse, F. W. Dodge Corporation, Personal Communication with Y. Joe Huang, LBL, June 8, 1990. 
Figure 2, also in the main body of the report, shows Census Bureau estimates of construction type in the 1980 s. The construction type is important because two-story houses are larger on the average than one story houses. The proportion of two-story houses has been increasing in all parts of the country (see Table 1). This increasing proportion of two-story houses is apparent from the greater number of base cities with two-story prototypes from the NAHB data compared with those in the previous report.

Because it was important to take account of construction type, we chose to use the Census Bureau data as the primary source. These data appear to be more robust than the NAHB state-by-state data and the F.W. Dodge data. In addition, we could not use building area estimates directly from the 1987 NAHB Builder Survey because the NAHB sample shows 1987 to be an abnormally high year for several states which include base cities used in this analysis. However, we did use construction type and building size estimates from these data in calculating average size from the Census Bureau data.

We made estimates of average 1980s square footage for each base city by combining Census Bureau square footage and construction type data (1980-89) for each census region with data from the 1987 NAHB Builder's Survey. We first used the Census Bureau data to develop weighted averages of floor area for the 1980 s by census region. We then took typical construction type and 1-story/2-story square foot data for each state from the NAHB survey. Using these two data sets, we calculated weighted average square foot estimates for one and two story buildings for each census region. The results are shown in Table 5.

Table 5. Calculation of Floor Area for New Single Family Buildings By Construction Type - Using Census Bureau and NAHB Data

\begin{tabular}{|c|c|c|c|c|c|c|c|c|c|}
\hline \multirow[b]{2}{*}{$\begin{array}{l}\text { Census } \\
\text { Region }\end{array}$} & \multicolumn{5}{|c|}{ Census Bureau Data, 1980-89 } & \multicolumn{2}{|c|}{ NAHB 1987 Data } & \multirow{2}{*}{\multicolumn{2}{|c|}{$\begin{array}{c}\text { Calculated } \\
\text { Average Area for } \\
\text { Construction Type }\left(\mathrm{ft}^{2}\right)\end{array}$}} \\
\hline & $\begin{array}{l}\text { Number } \\
(1000 \text { s })\end{array}$ & $\begin{array}{l}\text { Area } \\
\left(\mathrm{ft}^{2}\right)\end{array}$ & $\begin{array}{r}\text { Const } \\
1 \text { Story }\end{array}$ & $\begin{array}{l}\text { uction } T_{y} \\
2 \text { Story }\end{array}$ & $\begin{array}{l}\text { e (\%) } \\
\text { Split }\end{array}$ & $\begin{array}{l}\text { Const. } \\
\text { Type }\end{array}$ & $\begin{array}{l}\text { Area } \\
\left(\mathrm{ft}^{2}\right)\end{array}$ & & \\
\hline US & 9783 & 1832 & 53 & 41 & 6 & \begin{tabular}{|l|}
2 Story \\
1 Story \\
Difference
\end{tabular} & $\begin{array}{r}2280 \\
1670 \\
610\end{array}$ & $\begin{array}{l}2 \text { Story } \\
1 \text { Stery }\end{array}$ & $\begin{array}{l}2174 \\
1564\end{array}$ \\
\hline Northeast & 1332 & 1888 & 26 & 68 & 6 & \begin{tabular}{|l}
2 Story \\
1 Story \\
Difference
\end{tabular} & $\begin{array}{r}2455 \\
1743 \\
712 \\
\end{array}$ & $\begin{array}{l}2 \text { Story } \\
1 \text { Story }\end{array}$ & $\begin{array}{l}2094 \\
1382\end{array}$ \\
\hline North Centra & 1604 & 1827 & 47 & 39 & 14 & \begin{tabular}{|l}
2 Story \\
1 Story \\
Difference
\end{tabular} & $\begin{array}{r}2243 \\
1521 \\
722\end{array}$ & $\begin{array}{l}2 \text { Story } \\
1 \text { Story }\end{array}$ & $\begin{array}{l}2217 \\
1495\end{array}$ \\
\hline South & 4550 & 1816 & 63 & 34 & 3 & \begin{tabular}{|l}
2 Story \\
1 Story \\
Difference
\end{tabular} & $\begin{array}{r}2319 \\
1760 \\
559\end{array}$ & $\begin{array}{l}2 \text { Story } \\
1 \text { Story }\end{array}$ & $\begin{array}{l}2177 \\
1618\end{array}$ \\
\hline West & 2223 & 1831 & 55 & 38 & 7 & \begin{tabular}{|l}
2 Story \\
1 Story \\
Difference
\end{tabular} & $\begin{array}{r}2000 \\
1598 \\
402 \\
\end{array}$ & $\begin{array}{l}2 \text { Story } \\
1 \text { Story }\end{array}$ & $\begin{array}{l}2066 \\
1664\end{array}$ \\
\hline
\end{tabular}




\section{0s BUILDING SIZE DATA}

The only existing estimates of house size for 1990 s construction came from cumulative floor area and stock estimates provided by F.W. Dodge Corporation. We calculated average square footage for new construction in each state by subtracting existing stock and existing cumulative fioor area from each year's data and then dividing total new floor area by total new stock. The results are shown in Table 6.

We also analyzed the Census Bureau data to develop an estimate for 1990 s construction based on trends in the 1980 s data. To account for the impact of the trend in construction types, we calculated the change in average square footage for each census region using the construction type percentages from the Census Bureau data and assumed one- and two-story square footage values taken from the 1987 NAHB builders survey database. We compared these calculated values to the change in mean square footage in Census Bureau reports over the same period. The difference between the two represents the change in average house size irrespective of the trend in construction types. The results are shown in Table 7, both for the period 1980-1989 and 1987-1989.

Table 7. Analysis of Bullding Size Trends, 1980-1989

Calculated from Census Bureau Data, New Single Family Construction

\begin{tabular}{|l|ccc|ccc|}
\hline & \multicolumn{3}{|c|}{$1980-1989$} & \multicolumn{3}{c|}{$1987-1989$} \\
Census Region & $\Delta$ Mean & $\Delta$ Calc'd & Difference & $\Delta$ Mean & $\Delta$ Calc'd & Difference \\
\hline All US & 295 & 97 & 198 & 130 & 18 & 112 \\
\hline Northeast & 305 & 117 & 188 & 120 & 46 & 74 \\
N. Central & 285 & 87 & 198 & 80 & 18 & 62 \\
South & 280 & 73 & 207 & 115 & 11 & 104 \\
West & 330 & 107 & 223 & 195 & 39 & 156 \\
\hline
\end{tabular}

$\Delta$ Mean $=$ difference in mean square footage between years indicated from Census Bureau report data.

$\Delta$ Calculated $=$ difference in area calculated using construction type from Census Bureau reports and constant building size. Estimate of change due to increasing proportion of 2 story buildings.

Difference $=$ difference between $\Delta$ mean and $\Delta$ calculated. Estimate of change in average house size removing effect of increasing proportion of 2-story buildings. 
Table 6. Calculated Average Square Footage for New Construction, 1991-2000

From Data provided by F.W. Dodge Corporation

\begin{tabular}{|c|c|c|c|c|c|c|c|c|c|c|c|}
\hline ST & 1991 & 1992 & 1993 & 1994 & 1995 & 1996 & 1997 & 1998 & 1999 & 2000 & 1990's \\
\hline$\overline{A L}$ & 1794 & 1836 & 1823 & 1809 & 1798 & 1802 & 1806 & 1811 & 1817 & 1823 & 1812 \\
\hline AK & 1688 & 1691 & 1662 & 1644 & 1634 & 1636 & 1638 & 1642 & 1651 & 1650 & 1654 \\
\hline$A Z$ & 1759 & 1768 & 1765 & 1763 & 1757 & 1759 & 1763 & 1768 & 1772 & 1777 & 1765 \\
\hline AR & 1800 & 1825 & 1805 & 1800 & 1795 & 1798 & 1801 & 1810 & 1814 & 1819 & 1806 \\
\hline CA & 1903 & 1926 & 1919 & 1916 & 1911 & 1913 & 1918 & 1923 & 1929 & 1934 & 1919 \\
\hline$\infty$ & 1941 & 1924 & 1877 & 1849 & 1832 & 1835 & 1840 & 1843 & 1849 & 1854 & 1864 \\
\hline$C T$ & 1923 & 1950 & 1915 & 1884 & 1864 & 1866 & 1871 & 1876 & 1883 & 1887 & 1892 \\
\hline DE & 1739 & 1779 & 1786 & 1780 & 1782 & 1785 & 1790 & 1795 & 1801 & 1805 & 1784 \\
\hline DC & 1500 & 1531 & 1547 & 1568 & 1580 & 1579 & 1578 & 1575 & 1577 & 1573 & 1561 \\
\hline$F L$ & 1771 & 1778 & 1772 & 1765 & 1760 & 1763 & 1767 & 1771 & 1776 & 1781 & 1770 \\
\hline GA & 1761 & 1796 & 1810 & 1817 & 1822 & 1824 & 1829 & 1833 & 1839 & 1843 & 1817 \\
\hline HI & 1654 & 1633 & 1606 & 1575 & 1547 & 1549 & 1553 & 1557 & 1561 & 1565 & 1580 \\
\hline ID & 1935 & 2035 & 2029 & 2014 & 2001 & 1998 & 2003 & 2010 & 2020 & 2020 & 2007 \\
\hline IL & 1811 & 1836 & 1834 & 1830 & 1825 & 1827 & 1833 & 1838 & 1844 & 1851 & 1833 \\
\hline IN & 1873 & 1912 & 1898 & 1881 & 1869 & 1873 & 1877 & 1884 & 1890 & 1895 & 1885 \\
\hline IA & 2230 & 2354 & 2214 & 2079 & 2025 & 2029 & 2036 & 2039 & 2055 & 2063 & 2112 \\
\hline KS & 1823 & 1863 & 1852 & 1839 & 1832 & 1834 & 1836 & 1846 & 1851 & 1855 & 1843 \\
\hline KY & 1809 & 1856 & 1842 & 1827 & 1816 & 1817 & 1824 & 1828 & 1835 & 1841 & 1830 \\
\hline LA & 1754 & 1767 & 1755 & 1750 & 1744 & 1748 & 1751 & 1758 & 1763 & 1768 & 1756 \\
\hline ME & 1796 & 1846 & 1850 & 1856 & 1856 & 1859 & 1862 & 1868 & 1874 & 1878 & 1855 \\
\hline MD & 1782 & 1816 & 1843 & 1868 & 1880 & 1882 & 1887 & 1892 & 1898 & 1903 & 1865 \\
\hline MA & 1853 & 1884 & 1875 & 1862 & 1851 & 1853 & 1857 & 1863 & 1869 & 1874 & 1864 \\
\hline MI & 1914 & 1988 & 1967 & 1942 & 1929 & 1931 & 1937 & 1944 & 1951 & 1958 & 1946 \\
\hline $\mathrm{MN}$ & 1816 & 1841 & 1830 & 1814 & 1806 & 1808 & 1813 & 1819 & 1824 & 1829 & 1820 \\
\hline MS & 1811 & 1870 & 1854 & 1840 & 1825 & 1828 & 1832 & 1838 & 1844 & 1849 & 1839 \\
\hline MO & 1852 & 1904 & 1885 & 1858 & 1845 & 1847 & 1851 & 1859 & 1864 & 1869 & 1863 \\
\hline MT & 1956 & 2077 & 2045 & 2020 & 1997 & 1998 & 2000 & 2008 & 2013 & 2021 & 2014 \\
\hline NE & 1879 & 1931 & 1890 & 1851 & 1829 & 1835 & 1839 & 1846 & 1849 & 1858 & 1861 \\
\hline NV & 1667 & 1688 & 1702 & 1718 & 1724 & 1726 & 1731 & 1734 & 1739 & 1743 & 1717 \\
\hline NH & 1742 & 1779 & 1784 & 1790 & 1790 & 1793 & 1795 & 1801 & 1806 & 1810 & 1789 \\
\hline NJ & 1891 & 1919 & 1889 & 1866 & 1853 & 1855 & 1859 & 1864 & 1870 & 1875 & 1874 \\
\hline NM & 1828 & 1883 & 1857 & 1848 & 1846 & 1848 & 1852 & 1857 & 1862 & 1866 & 1855 \\
\hline NY & 1931 & 2003 & 1995 & 1987 & 1983 & 1985 & 1989 & 1996 & 2004 & 2010 & 1988 \\
\hline NC & 1788 & 1803 & 1799 & 1793 & 1789 & 1791 & 1796 & 1800 & 1805 & 1810 & 1797 \\
\hline ND & 1809 & 1825 & 1782 & 1744 & 1732 & 1731 & 1739 & 1740 & 1752 & 1752 & 1761 \\
\hline $\mathrm{OH}$ & 1864 & 1902 & 1893 & 1882 & 1872 & 1875 & 1881 & 1887 & 1893 & 1900 & 1885 \\
\hline OK & 1688 & 1707 & 1701 & 1709 & 1706 & 1709 & 1713 & 1719 & 1725 & 1730 & 1711 \\
\hline OR & 2016 & 2088 & 2069 & 2056 & 2035 & 2040 & 2043 & 2049 & 2057 & 2064 & 2052 \\
\hline PA & 1993 & 2057 & 2038 & 2015 & 2004 & 2006 & 2010 & 2016 & 2024 & 2031 & 2019 \\
\hline RI & 2053 & 2089 & 2037 & 1984 & 1951 & 1952 & 1954 & 1960 & 1969 & 1974 & 1992 \\
\hline SC & 1764 & 1790 & 1784 & 1772 & 1766 & 1769 & 1773 & 1779 & 1783 & 1789 & 1777 \\
\hline SD & 1911 & 1929 & 1859 & 1794 & 1771 & 1769 & 1773 & 1781 & 1789 & 1789 & 1816 \\
\hline $\mathbf{T N}$ & 1791 & 1828 & 1816 & 1804 & 1791 & 1794 & 1797 & 1803 & 1809 & 1814 & 1805 \\
\hline TX & 1815 & 1824 & 1809 & 1801 & 1794 & 1797 & 1801 & 1806 & 1812 & 1817 & 1808 \\
\hline UT & 1895 & 1930 & 1912 & 1901 & 1897 & 1899 & 1903 & 1908 & 1914 & 1919 & 1908 \\
\hline VT & 1730 & 1774 & 1793 & 1810 & 1821 & 1821 & 1826 & 1832 & 1836 & 1842 & 1808 \\
\hline VA & 1836 & 1824 & 1805 & 1786 & 1769 & 1772 & 1777 & 1781 & 1786 & 1791 & 1793 \\
\hline WA & 1913 & 1970 & 1977 & 1983 & 1977 & 1980 & 1984 & 1990 & 1997 & 2002 & 1977 \\
\hline WV & 4044 & -2014 & 5207 & 2477 & 2352 & 2351 & 2353 & 2368 & 2402 & 2390 & 2393 \\
\hline WI & 1898 & 1939 & 1913 & 1891 & 1878 & 1881 & 1885 & 1891 & 1897 & 1903 & 1898 \\
\hline WY & 1874 & 1936 & 1920 & 1905 & 1882 & 1892 & 1891 & 1900 & 1903 & 1912 & 1901 \\
\hline
\end{tabular}

Source: Unpublished data. Doug Poutasse, F. W. Dodge Corporation, Personal Communication with Y. Joe Huang, LBL, May 14, 1990. 


\section{Discussion}

The data from F.W. Dodge for 1990s construction shown in Table 6 implies that for states which include base cities, average square footage of new single family construction in the 1990s will increase between 0 and 80 square feet from 1991 to 2000. In Colorado, however, average square footage is projected to decrease by 87 square feet.

The analysis of the Census Bureau data shows that, in each census region, house size grew about 188 to 223 square feet between 1980 and 1989 even when removing the effect of the change in proportion of one- and two-story houses. In just the last three years of the decade, 1987 to 1989 , average house size grew by 62 to 156 square feet, depending on the region.

\section{CONCLUSIONS}

Because the trend towards increasing house size seems to be strong and prevalent through all areas of the country, we assumed that house size would continue to increase at approximately the same rate per decade into the 1990s. The most straightforward method for estimating the size of 1990 s vintage houses is to add the 1980 to 1989 square footage increase identified above to the 1980s house size for each base city in the appropriate census region. An alternative method, adding the 1987 to 1989 house size increase to the Dodge data projections through the 1990s gives similar results of between 100 and 200 square foot increase. Based on the former method, the 1980 and 1990 prototype house type and sizes will be as given in Table 8. The $\mathrm{D}+$ house sizes were estimated using the methodology described in the main body of the report. The expected impact on the resulting space conditioning loads of a $10 \%$ increase in floor area is approximately $50-80 \%$, depending on whether heating or cooling loads are considered.

Table 8. Prototype Size for 1980 s and 1990s Single Family buildings

\begin{tabular}{lcccclcccc}
\hline & \multicolumn{4}{c}{ Floor Area $\left(\mathrm{ft}^{2}\right)$} & \multicolumn{4}{c}{ Floor Area $\left(\mathrm{ft}^{2}\right)$} \\
Base City & Stories & $1980 \mathrm{~s}$ & $1990 \mathrm{~s}$ & $1990+$ & Base City & Stories & $1980 s$ & $1990 \mathrm{~s}$ & $1990+$ \\
\hline Boston & 2 & 2090 & 2280 & 3850 & Fort Worth & 1 & 1620 & 1830 & 3200 \\
New York & 2 & 2090 & 2280 & 3850 & New Orleans & 1 & 1620 & 1830 & 3200 \\
Chicago & 2 & 2220 & 2420 & 3990 & Denver & 2 & 2070 & 2290 & 3860 \\
Minneapolis & 2 & 2220 & 2420 & 3990 & Albuquerque & 1 & 1660 & 1880 & 3250 \\
Kansas City & 2 & 2220 & 2420 & 3990 & Phoenix & 1 & 1660 & 1880 & 3250 \\
Washington & 2 & 2180 & 2390 & 3960 & Seattle & 2 & 2070 & 2290 & 3860 \\
Atlanta & 2 & 2180 & 2390 & 3960 & San Francisco & 2 & 2070 & 2290 & 3860 \\
Miami & 1 & 1620 & 1830 & 3200 & Los Angeles & 2 & 2070 & 2290 & 3860
\end{tabular}


APPENDIX C: SAMPLE DOE-2 INPUT FILE FOR PROTOTYPE C, CHICAGO

C-1 


\section{DOE-2 INPUT FILE FOR PROTOTYPE C, CHICAGO}

POST-PROCESSOR PARTIAL ...

$s$

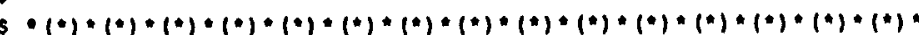

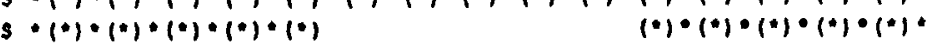
$s \cdot(\cdot) \cdot(\cdot) \cdot(\cdot) *(*) *(\cdot)$ File name: LDS.1FAM $(*) *(*) \cdot(*) *(*) *(*)$ $s *(*) *(*) *(*) *(\cdot) *(*)$ Date: Aug $311989 \quad(*) *(*) *(*) *(*) *(*)$ $s \cdot(* 1 \cdot(\cdot) \cdot(\cdot) \cdot(\cdot) \cdot(\cdot) \quad(*) \cdot(*) \cdot(*) \cdot(*) \cdot(*)$ $(\cdot(*) \cdot(*) *(\cdot) \cdot(*) \cdot(*) *(\cdot) \cdot(\cdot) \cdot(*) \cdot(\cdot) \cdot(\cdot) \cdot(*) *(*) \cdot(*) *(\cdot) *(*) *$

INPUT LOADS ..

TITLE LINE-1 - CHIC- $C$

(13-32-00-db1)

LINE-2: Al UMI RO-B C33 2-8to gar-y

LINE-3 - ChICago I

LINE-4:

LINE-5 -

PARAMETER

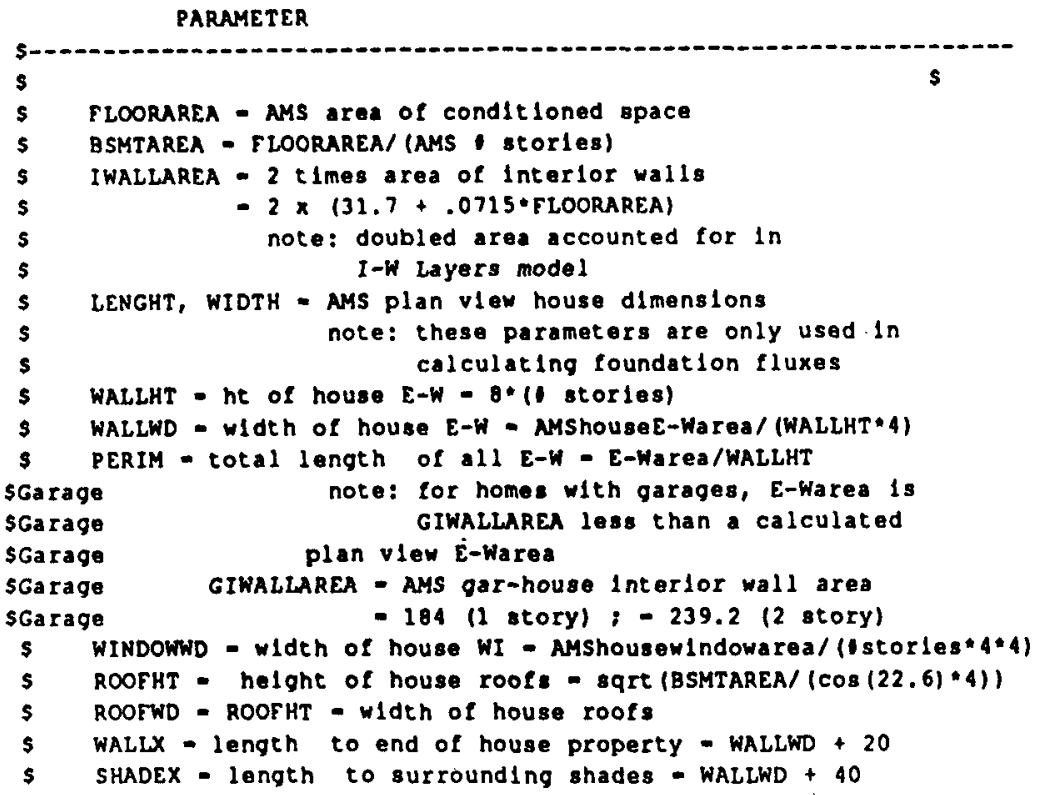

SChlC- Input obtained from Census/NaHB data for Chlcago

SChIC- 2-story \$ CONDAREA - 2220.

SChIC- 2-story S FLOORAREA-2220 PERIM-120.336

SChIC- 2-story S IWALLAREA-380.86

schlc- 2-story foundation length - 39.64, w1dth $=28.00$

SChIC- 2-story BSMTAREA-1110

SChlC- 2-story 5 WALLWD-30.0839 WALLHT-16 WINDOWWD- 8.60

SCh1C- 2-story S WALLX-50.0839 SHADEX-70.0839

SCh1C- 2-story \$ ROOFHT-17.3373 ROOFWD-17.3373

SGarage $\$$ GARAREA 460

\$2-stgarage $\$$ GIWALLAREA-239.2 S---Reglonal based equI pment load-
SENCC-LoadS RECSVAL-0.96 SENSLD-0.8BS LATLD-0.115 UNCLD-0.141

5--- Conservation parameter:

SInt15 SINFILT -.0005

\$dbl 2-pane wlndow S WINDOWGT - WINDOW-2

SCh1cag Ch1C Bsmt R13 S FDNUEFF $=.3312$ S GndU-.1409 GndT-53

SROBSmT \$ B1WALLHT-B B2WALLHT 0.00001

\$2×4studs MS $=0.25$

$\$ 2 \times 4$ studs MNS -0.75

sE-W slding thickness (from does layers library)

SAl uml \$ EWSTH-.005 \$doe2 llbrary code: ASO1

SE-W Insulation board thlekness (from doez layers library) IN61TH-.0417\$doe2 l1brary code: IN61

IN34TH-. 1042 \$doe2 11 brary coda: IN34

IN35TH-.1667 \$doe2 llbrary code: IN35

SE-W other materlals (from doe2 layers library) GPTH-0.0417 Sdoe2 11brary code: GPO1

SRoof Insulation thlcknesies

SRFINTH is the thickness of the Insulation in the cavity

SRFINJTH is the thickness of Insulation on top of jolst

SR32RF S RFINTH= 0.0416 RTINJTH = 0.3119

S --- end of parameters

RUN-PERTOD

DIAGNOSTIC

BUILDING-LOCATION
JAN 11986 THRU DEC $311986 \ldots$

CAUTIONS, WIDE, ECHO, SINGLE-SPACED .

HTT -41.8 LON $=87.8$ T-2-6 ALT $=658$ WS-HEIGHT-LIST -

$(20,20,20,20,20,20,20,20,20,20,20,20)$ AZIMUTH $=0$ SHIELDING-COEF -0.19 TERRAIN-PAR1-.85 TERRAIN-PAR2-. 20 W5-TERRAIN-PAR1=.85 WS-TERRAIN-PAR2 $=.20$ 
TUNCTION - I*SHADING*, *NONE*I

ABORT WARNINGS

LOADS-REPORT SUMMARY-(LS-E)

Loads Schedules -.......-... L

the following were taken from A.M.S. Input elles:

che lo1 loulng were caken erom a,

5 OCCUPANCY hEAT GAIN SCHEDULES

5 ocup. magnitudes and schedules taken from C.E.C. study OCC1-SCH THRU DEC 31 (ALL)

$(1,24) \quad(0.44,0.44,0.44,0.44,0.44,0.44,0.53,0.87,0.43,0.52,0.63,0.21$ $0.14,0.00,0.00,0.29,0.29,0.64,0.81,1.00,0.96,0.09,0.77,0.14) \ldots$

$\$$ EOUIPMENT SCHEDULES $\$$

s equip schedule shapes taken from C.E.C. study $S$ winter COP-W-W-SCH (ALU)

$(1,24) \quad(0.22,0.22,0.17,0.17,0.17,0.14,0.41,0.41,0.57,0.57,0.81,0.81$ $0.79,0.79,0.74,0.74,1.00,1.00,0.73,0.73,0.61,0.61,0.53,0.531 \ldots$ 5 Spring/rall

EOP-SF-W-SCH (ALL)

$(1,24) \quad(0.24,0.24,0.19,0.19,0.19,0.18,0.40,0.40,0.51,0.51,0.71,0.71$ $0.69,0.69,0.69,0.69,0.90,0.90,0.67,0.67,0.60,0.60,0.52,0.521 \ldots$ 5 summer

$(1,24) \quad(0.26,0.26,0.21,0.21,0.22,0.22,0.40,0.40,0.45,0.45,0.62,0.62$ $0.59,0.59,0.64,0.64,0.80,0.80,0.62,0.62,0.57,0.57,0.52,0.521 \ldots$ EQUTPL-SCH THRU FEB 28 WEEK-SCHEDULE $-E O P-W$ THRU MAY 31

WEEK-SCHEDULE-EOP-SF

THRU AUG 31 WEEK-SCHEDULE-EOP-S THRU NOV 30 WEEK-SCHEDULE-EQP-SF THRU DEC 31 WEEK-SCHEDULE-EOP-W

$\checkmark$ LIGHTING SCHEDULES :

\$11te magnitude and schedule shapes taken from C.E.C. study $\$$ winter

LITG-W-W-SCH (ALL)

$(1,24) \quad(0.18,0.18,0.09,0.09,0.09,0.09,0.27,0.27,0.18,0.18,0.09,0.09$ $0.09,0.09,0.09,0.09,0.46,0.46,1.00,1.00,0.91,0.91,0.55,0.551 \ldots$ S Spring/Fall

LITG-SE-W-SCH (ALL)

$(1,24) \quad(0.14,0.14,0.04,0.04,0.07,0.07,0.18,0.18,0.18,0.18,0.14,0.14$

$0.14,0.14,0.14,0.14,0.29,0.29,0.57,0.57,0.75,0.75,0.54,0.541 \ldots$ $\$$ summer

LITG-S-W-SCH (ALL)

$(1,24) \quad(0.10,0.10,0.00,0.00,0.05,0.05,0.10,0.10,0.16,0.16,0.16,0.16$ $0.16,0.16,0.16,0.16,0.16,0.16,0.26,0.26,0.57,0.57,0.47,0.471 \ldots$

LTG1-SCH THRU FEB 28 WEEK-SCHEDULE-LITG-W THRU MAY 31
WEEK-SCHEDULE-LITG-SF

THRU AUG 31 WEEK-SCHEDULE-LITG-S THRU NOV 30 WEEK-SCHEDULE-LITG-SF THRU DEC 31 WEEK-SCHEDULE-LITG-W.

The following shading schedule 1s modlfled by function SHADING $s$ to give .63 durling the coollng season deflned as perlods wlth

s more than 5 cooling degree days for the four prevlous days.

SHADCO SCHEDULE THRU DEC 31 (ALL) $(1,24) \quad 0.801$..

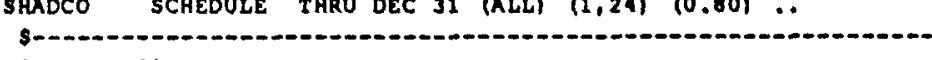

3--.- Glass types

5 Windows modeled using glass-type code.

$\$$ U-values based on ASHRAE winter values with

s outside $111 \mathrm{~m}$ coefflclents subtracted:

$\$$ ASHRAE InPUE

$\$ \mathrm{sgl} \quad 1.1 \quad 1.35$

Sobl $\quad .49 \quad .535$

s.s inch alr ger

WINDOW-1 GLASS-TYPE

PANES- 1 GLASS-TYPE-CODE-

GLASS-CONDUCTANCE-1.35 ..

WINDOW-2 GLASS-TYPE

PANES -2 GLASS-TYPE-CODE -1

GLASS-CONDUCTANCE-.535

WINDOW-3 GLASS-TYPE

PANES-3 GLASS-TYPE-CODE- 1

GLASS-CONDUCTANCE-.327 ..

\section{s-o- materials -}

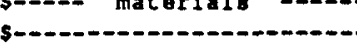

WOOD - MATERIAL $\$$ Ref eshrae

S1/2" the .0417 ft, $2 \times 4$ the $=.2917 \mathrm{ft}, 2 \times 6 \mathrm{th}=.4583 \mathrm{ft}$

s $2 \times 10-.7917 \mathrm{ft}$

THICKNESS-1. CONDUCTIVITY -.0667

DENSITY-34. SPECITIC-HEAT=.29..

INSUL - MATERIAL S Ref ashrae - mid-range value

THICKNESS -1 . CONDUCTIVITY -.0263

DENSITY-1.15 SPECITIC-HEAT =.20 ..

SHINGLE - MATERIAL S Asphalt shingle ref ashrae

\$ Usually .0208 it thlck

THICKNESS-1. CONDUCTIVITY $=.0472$

DENSITY $=70 . \quad$ SPECIFIC-HEAT-.3.

ATTIC - MATERIAL $\$$ Ave summer, winter of hor +45 deg

S Fllm reslatances. ref ashrae

RESISTANCE- 1.455 . 


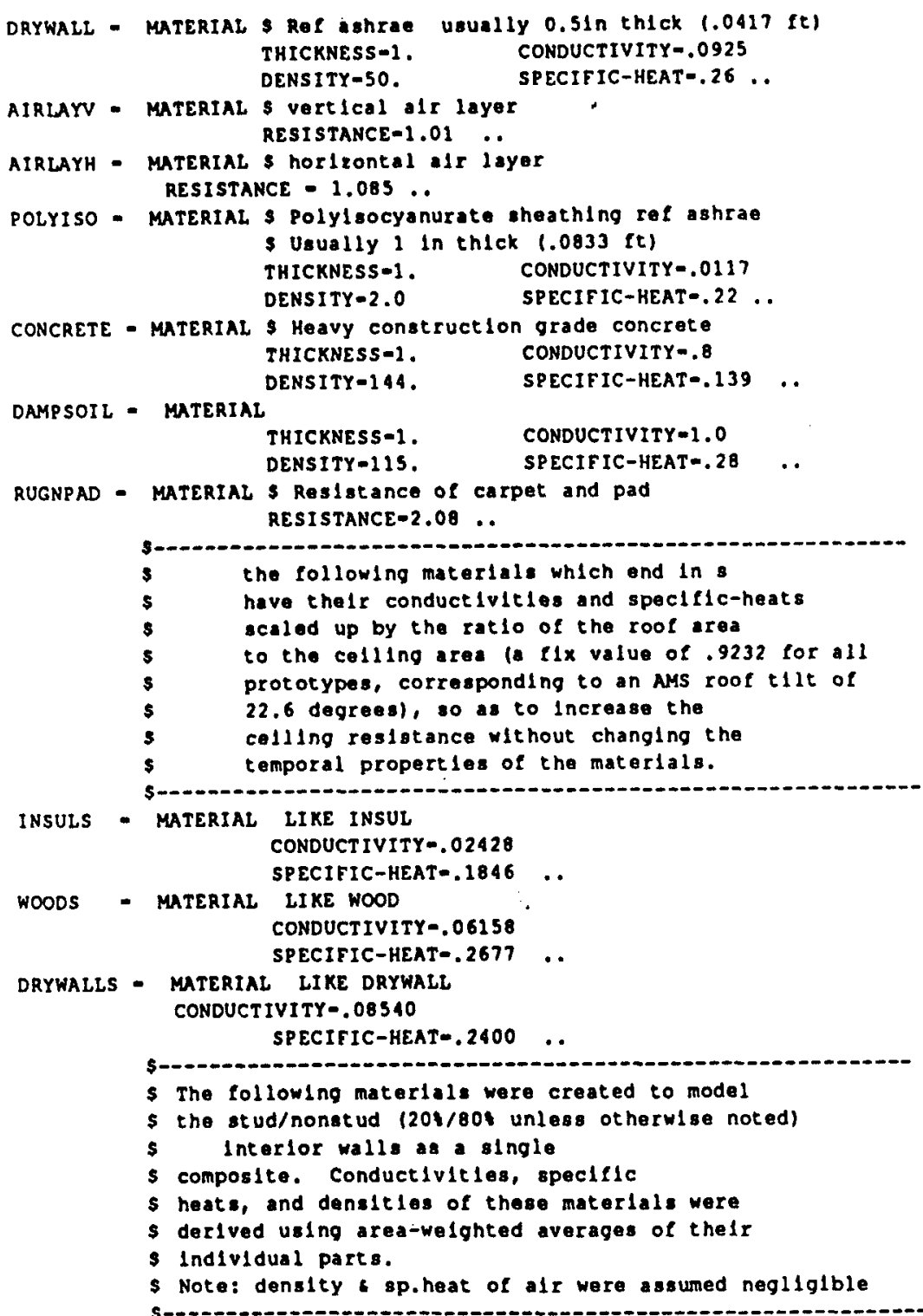

HALFWDROV- MATERIAL \$1/2thlckness, $2 \times 4$ mood c vertleal alf composite THICKNESS - 1. CONDUCTIVITY-.1171 DENSITY-6.8 SPECIFIC-HEAT-. OSB

HALFWDROH- MATERIAL $\$ 1 / 2$ thlckness, $2 \times 10$ wood horiz. Ir composite note: 201jolst 90inonjolat rat 10 used

THICKNESS - 1 . CONDUCTIVITY -.2521

DENSITY-3.4 SPECIFIC-HEAT-.029

WDRI1 - MATERIAL $\$ 2 \times 4$ mood G R-11 Insulation composite THICKNESS - 1 . CONDUCTIVITY - .03015

DENSITY-7.72 SPECIFIC-HEAT-0.218 .

WORI3 - MATERIAL $\$ 2 \times 4$ wood \& R-7talrlayv Insulation composite THICKNESS - 1 . CONDUCTIVITY $=.04005$

DENSITY -7.72 SPECIFIC-HEAT -0.218

WDR19 - MATERIAL \$2×6wood \& R-19 Insulation composite THICKNESS - 1 . CONDUCTIVITY-.02905 DENSITY -7.72 SPECIFIC-HEAT -0.218

s-o-$$
s-
$$

$\$$ Wall and roof section notes :

$s$

$S$ EXTERIOR WALLS

\$2x4stud of R-11 and 1ess are modeled as bullt of

$52 \times 48 t u d \quad 2 \times 48$ on 16 Inch frames $(25$ atud).

\$2x4stud R-13 insulation was achelved using R-7 Insulation

\$2x4stud plus additional polystyrene sheathing.

5 Thls percentage 18 reflected in the wall multipllers

5 MNS (multipller for no stud) and MS (multlpler for stud).

S-It surpasses $1 t^{*}$.

s counterpart R-1 with the addition of polystyrene insulating

s sheathing (IN61 to IN34). IN34 was used to approximate R-13

5 walls (whlch only have $R-7$ insulation)

$\$$ and therefore R-13+s counterpart 1. Improved w/IN3s.

3

S The multipliers for exterlor walls have greater percentage s of stud than interlor walls, floors and roofs.

5 INTERIOR WALLS are modeled as bullt of $2 \times 48$ on 16 Inch frames s (1.e. 20 stud). To reduce the number of layers needed, sthe stud/nonstud portions of interlor walle were lumped

s the stud/nonstud portions of interlor walls were

$\$$ together in one layer using composlte materlals. s with twice the cross-sectlonal area. Internal floors/cellings $s$ wera also modeled as composites (w/a 10 folst rat 1o) 
CEILINGS AND ATtICS are modeled in the roof layer. Roofs are

s bullt of $2 \times 6$ jolat $(10$ jolst $)$. Celling conductivities

$s$ and speclfle heats have been reduced to account for thelr

s enlarged area (all materials ending in.s).

rLOORS are modeled as $2 \times 10$ jolats on $\mathrm{g} / 4$ in plywood. 110 jolst

slth thls exception, 11 the prevlously mentioned surfaces

have $1 / 2$ in plywood.

SUNCA S UNCWALLNSL-LAYERS SR-Ouncond, wall:alum frame slding, no atud

SUNCA 3 MATERIAL- (ASO1, IN61)

$\begin{array}{lll}\text { SUNCA } & 3 & \text { MATERIAL- (ASOI, IN61) } \\ \text { SUNCA } & \$ & \text { THICKNESS- (EWSTH, IN61TH) }\end{array}$

SUNCA S ' INSIDE-FILM-RES-.68

SRI3A S WALLNSL-LAYERS SR-13Wa1l:alum frame a slding, no stud

SRI3A S MATERIAL- (AS01, IN34, INSUL, AIRLAYV, GPO1)

SR13A THICKNESS - (EWSTK, IN34TH, .1841, 1, GPTH)

SRIJA I INSIDE-FILM-RES-.68

SUNCA S UNCWALLSL - LAYERS SR-Ouncond,wall:alum frame slolng, stud

SUNCA $\$$ MATERIAL- (ASO1, IN61, WOOD)

SUNCA
SUNCA SUNCA
SUNCA

in

\$ MALLSL - LAYERS

SR13A MALLSL a LAYERS SR-13Wall:alum Trame Blding, stud

SR13A MATERIAL- (ASO1, IN34, WOOD, GPO1)

STHICKNESS- (EWSTH, IN34TH, . 2917, GPTH)

INSIDE-FILM-RES-.68 ..

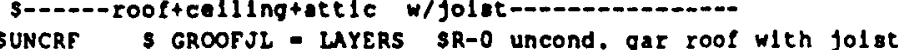

$\begin{array}{ll}\text { SUNCRF GROOFJL - LAYERS } & \$ R-0 \text { uncond, gar roo wlh jolst } \\ \text { SUNCRF } & \$ 1 / 21 \mathrm{n} \text { plywood, } 5.51 \mathrm{n} \text { jolst lumped together }\end{array}$

SUNCRF \$ MTERIAL-(SHINGLE, WOOD)

SUNCRF $\$$ THICKNESS- $\left(.020 \mathrm{~B}_{1} .5\right)$

INSIDE-FILM-RES=.765 .. savg heat up and down

ROOFJL - LAYERS SHOUse roof with jolst

MATERIAL- (SHINGLE, WOOD, ATTIC, INSULS, WOODS,

DRYWALLS)

THICKNESS $-1.0208, .0417,1$, RFINJTH, .4583

.04171

INSIDE-FILM-RES- $.765 \ldots$ Savg heat up and down

S----roof tattictcolling no jolst

SUNCRF \$ GROOFNJL - LAYERS \$R-0 uncond. gar-roof with no jolst

SUNCRF S MATERIAL- (SHINGLE, WOOD)

SUNCRE \$ THICKNESS-1.0208,.0417

SUNCRF S INSIDE-FILM-RES-.765 Savg heat up and down

ROOFNJL - LAYERS SHOUse rOOF WIth no fol Bt

MATERIAL- (SHINGLE, WOOD, ATTIC, INSULS, DRYWALLS)

THICKNESS $-1.0208, .0417,1$, REINTH, .0417$)$

INSIDE-FILM-RES-.765 .. Savg heat up and down sconslab uninsul.bsmt wal1/s1ab a gar slab on dampsols

sconslab note: In order to decrease of layers needed,

sConslab R-0 bsmt, wall and slab la modeled as the same layer,

Conslab wlth an eve. 6 " thleknese (4" alab, 8" wall)

conslab Garage ilab 1 s also modeled with thls laye

SCOnslab $\$$ BGRNDL - LAYERS

sconslab s

sconslabs

sconslab $\$$

INSIDE-FILM-RES-0.765 ...

SROBsmt S BWALL2L - LAYERS 5 unlngulated basement wall dampsoll

SROBsmt 5 MATERIAL-(DAMP SOIL, CONCRETE)

SROBSTT THICKNESS- $(3.50, .667)$

SROBsmt

IWALLL - LAYERS S1/2Interlor Wall layer etud/nostud composite

MATERIAL - (DRYWALL, HALFWDROV)

THICKNESS - $(.0417, .1439)$

INSIDE-FILM-RES = .68 ..

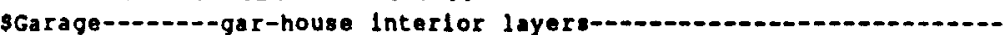

SGarage gar-house Interlor wall layers defined w.r.t. house space

SGarage (1.e. rlghtmost gypbonrd: olement nearest house space)

SR13G SIWALLL - LAYERS SR-13wall: 2X4atud/1neUl composite

SR136

sistor MATERIAL- (GP01, IN34, WDR13, GP01)

s-story \$ IFLOORL - LAYERS \$.75"plywood Int. floor w/jolst

\$2-story \$ $\$ 1 / 22 \times 10$ jolst/alrlayh composlte

2-story $\$$ MATERIAL - (HALFWDROH, WOOD, RUGNPAD)

\$2-story $S$ THICKNESS - $1.3958, .0625,1)$

S2-story $\$$ INSIDE-FILM-RES - .765 ..

\$2-story \$ ICEILL - LAYERS sdrywall Int, celling w/jolst

\$2-8tory

s2-story

s-story

s2-story

\$2-story

$\$ 1 / 22 \times 10$ jol set/al

MATERIAL - (HALFWDROH, DRYWALL)

THICKNESS - $(.3958, .0417)$

INSIDE-FILM-RES - .765 ..

Over unconditloned space layers-

SROOFL S TLOORJL - LAYERS SR-Ofloor W/Jolst; over uncond.

SROOFL S MATERIAL - (WOOD, RUGNPAD)

\$ROOFL $\$$ THICKNESS - $(.0542,1)$

INSIDE-FILM-RES - .765 ..

TLOORNJL- LAYERS SR-0 DloOT nO JOI

MATERIAL - (WOOD, RUGNAD

THICXNESS - $(.0625,1)$

INSIDE-FILM-RES - .765 .. 


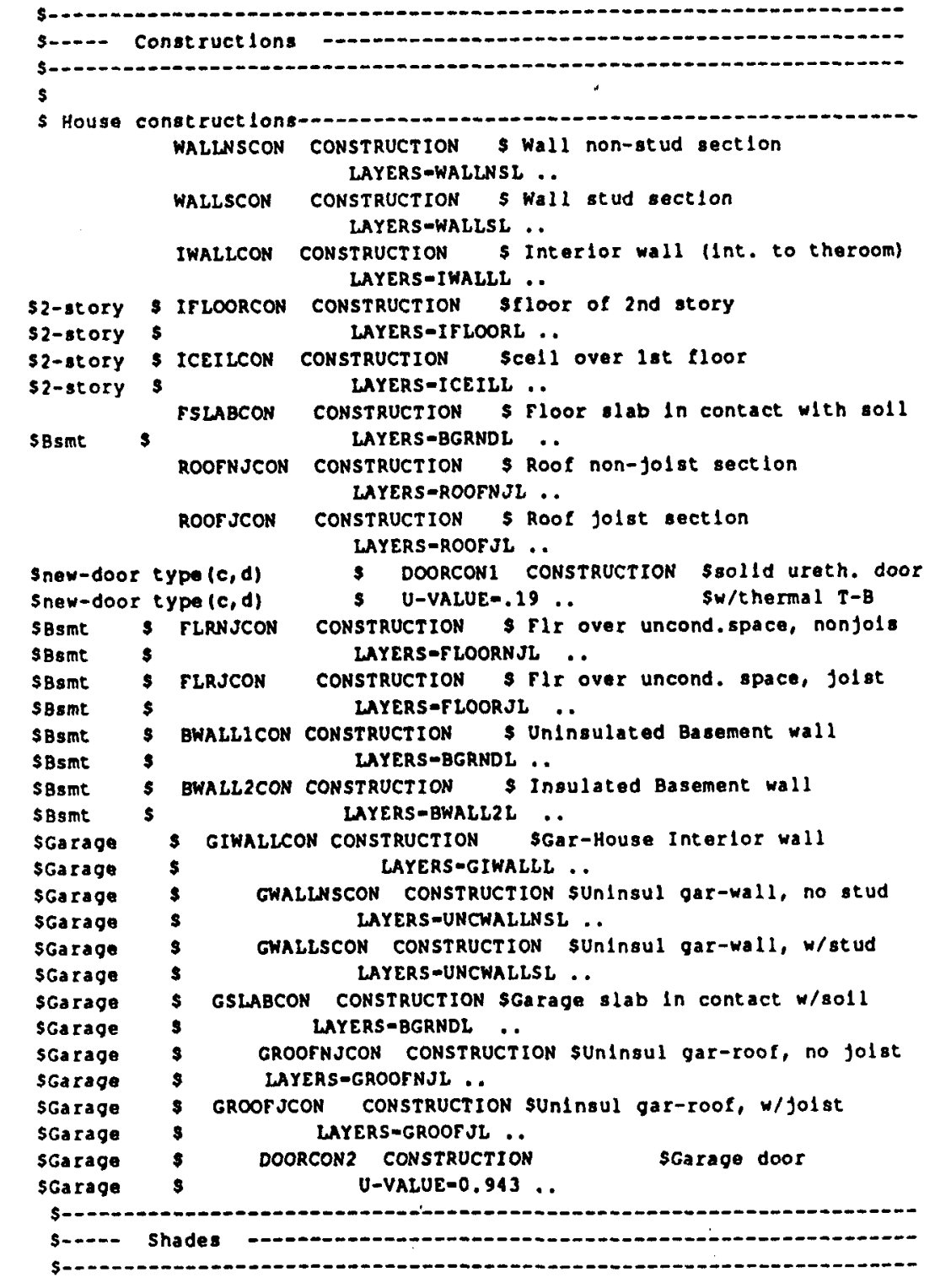

SURROUNDN BUILDING-SHADE S Effect of nelghborling houses north HEIGHT-10 WIDTH-SHADEX

$X=0$ Y SHADEX A2IMUTH-180

TRANSMITTANCE -0.50 TILT $=90$..

SURROUNDS BUILDING-SHADE S Effect of nelghborlng houses south LIKE SURROUNDN

$X-S H A D E X$ Y $Y 0$ A2 IMUTH $\rightarrow 0$..

SURROUNDE BUILDING-SHADE S Elfect of nalghboring houses east LIKE SURROUNDN

$X$-SHADEX Y-SHADEX AZIMUTH-270 ..

SURROUNDW BUILDING-SHADE S Elfect of nelghborling houses west LIKE SURROUNDN

$X \rightarrow 0 \quad Y=0$ AZ IMUTH $-90 \ldots$ 

THEROOM SPACE

SPACE-CONDIT IONS-ROOMCOND

AREA-FLOORAREA

VOLUME-FLOORAREA TIMES 6. .

IWALL INTERIOR-WALL

INT-WALL-TYPE-INTERNAL

AREA-IWALLAREA

CONSTRUCTION-IWALLCON ..

SGarage S GIWALL INTERIOR-WALL

$\begin{array}{lll}\text { SGarage } & \text { AREA-GIWALLAREA } \\ \text { SGarage } & \text { CONSTRUCTION-GIWALLCON }\end{array}$

SGarage \$ CONSTRUCTION-GIWALICC
SGarage \$ NEXT-TO-GARAGE

SGarage

EXTERIOR-WALI

WIDTH-WALLWD CONSTRUCTION-WALLSCON

$X$-WALLX Y-WALLX HEIGHT-WALLHT

MULTIPLIER - MS ..

NDOORS DOOR HEIGHT-6.5 WIDTH-.75 CONSTRUCTION-DOORCON $1 \quad x-3.0$.

NWINDIS WINDOW GLASS-TYPE-WINDOWGT $X-5.0 \quad Y-3$

HEIGHT-4.0 WIDTH-WINDOWHD SHADING-SCHEDULE-SHADCO

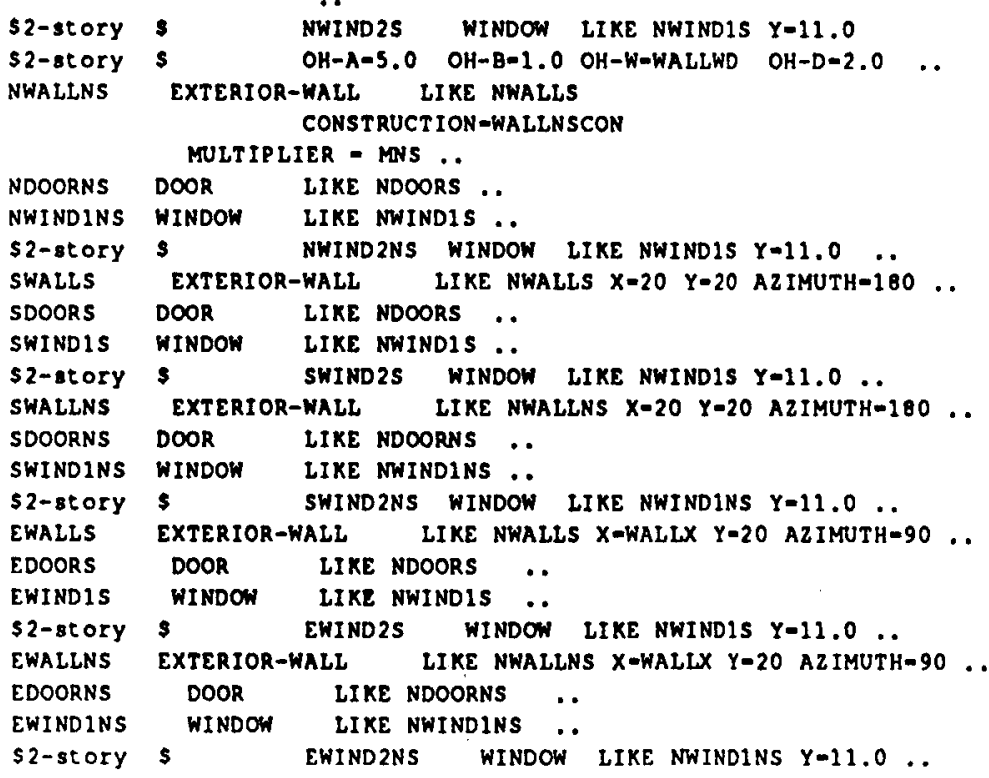

wharts

WDOORS

WWIND1S

\$2-8tory

WWALLNS

WDOORNS

WWIND1NS

s2-story

IFLOORIJ INTERIOR-WALL \& FloOr bet Theroom and Basement

TILT-180 CONSTRUCTION-FLRJCON

AREA-BSMTAREA TIMES . I NEXT-TO-BASEMENT.

SBsmt S IFLOORINJ INTERIOR-WALL S Floor bet Theroom and Basement

SBSmt $\$$ TILT-180 CONSTRUCTION-FLRNJCON

SBSmE $S$ AREA-BSMTAREA TIMES . 9 NEXT-TO-BASEMENT.

\$2-story $\$$ IFLOOR2 INTERIOR-WALI INT-WALL-TYPE-INTERNAL

\$2-story 9 AREA-BSMTAREA

\$2-Btory $\$$ CONSTRUCTION-IFLOORCON TILT-100.

S2-story 5 ICEIL INTERIOR-WALL INT-WALL-TYPE-INTERNAL

\$2-8tory $\$$ AREA-BSMTAREA

\$2-Btory \$ CONSTRUCTION-ICEILCON TILT-180 .

NROOFJ ROOF X-WALLX Y-WALLX 2-WALLHT HEIGHT-ROOFHT WIDTH-ROOFWD MULTIPLIER-0.1

CONSTRUCTION-ROOFJCON TILT-22.6

NROOFNJ ROOF LIKE NROOFJ

MULTIPLIER-0.9 CONSTRUCTION-ROOFNSCON $\because 0$
SROOFJ ROOF LIKE NROOFJ AZIMUTH-180 $x-20 \quad Y-20$

SROOFNJ ROOF LIKE NROOFNJ AZIMUTH-180 $x-20 \quad y-20 \quad \cdots$

EROOFJ ROOF LIKE NROOFJ AZIMUTH=90 X-WALLX $Y=20 \ldots$

EROOFNJ ROOF LIKE NROOFNJ AZIMUTH-90 $X$-WALLX $Y=20 \quad \ldots$

WROOFJ ROOF LIKE NROOFJ AZIMUTH-270 X-20 Y-WALLX ..

WROOFNJ ROOF LIKE NROOFNJ AZIMUTH-270 $x=20$ Y-WALLXX

sBsmt

sBsmt space

sBsmt

SBsmt

SBsmt \$ AREA-BSMTAREA VOLUME-BSMTAREA IIMES 8.

SBBmt $\&$ FURNITURE-TYPE-LIGHT

SBamt $S \quad$ FLOOR-WEIGHT-O

SBsmt \& E-KW-UNCLD

\$Bsmt \$ E-SCH-EOUIPI

SBSmT $\$$ ZONE-TYPE-UNCONDITIONED T-(70).

SBsmt S FNDIWALL UNDERGROUND-WALI S Basement wall w/o Insulation

sBsmt $\$$ HEIGHT-BIWALLHT WIDTH-PERIM

SBsmt CONSTRUCTION-BWALLICON TILT-90

SBsmt S U-EFFECTIVE-FDNUEFF

\$Bsmt \$ FUNCTION = 1 NONE 9 PNDO $)$

SBsmt S FND 2WALL UNDERGROUND-WALL 's Basement wall with insulation

SBSmt S HEIGHT-B2WALLHT WIDTHAPERIM 


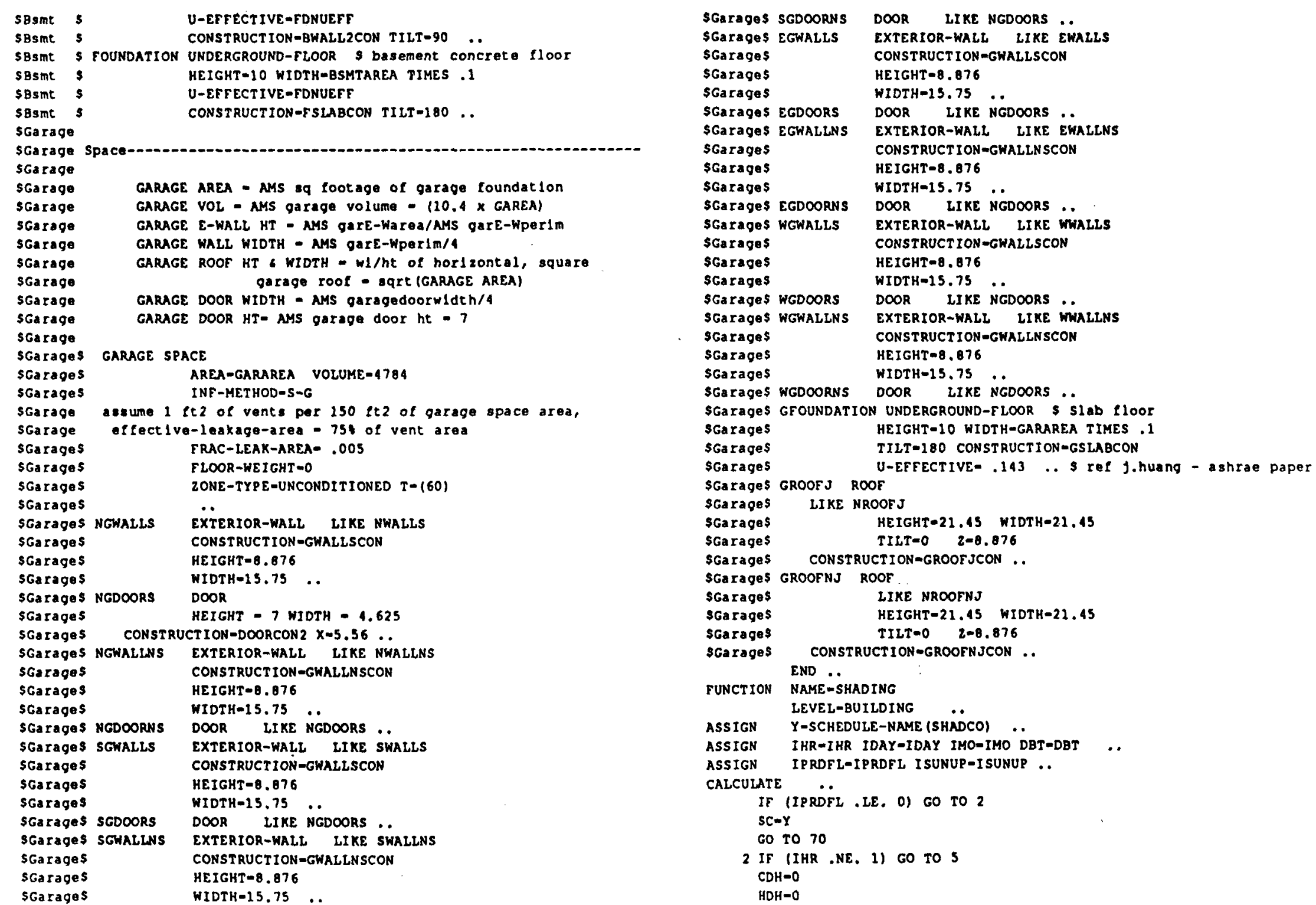


VTYPE $=-1$

sruens

sfurn $\$$

s2-story

$\$ 2-$ story

s-..-

systems schedules

HTSCH SCHEDULE 5 heat temperature schedule, 1 hour nlght setback THRU DEC 31 (ALL) $(1,6)$ (SETBACK)

$$
\begin{array}{ll}
(7,23) & \text { (HEATSET) } \\
(24) & \text { (SETBACK) }
\end{array}
$$

CTSCH SCHEDULE $\$$ cool temperature schedule, 7 hour day setup THRU DEC 31 (ALL) $(1,9)$ (COOLSET)

$$
(10,16) \text { (SETUP) }
$$$$
\text { (17,24) (COOLSET) }
$$

VTSCH SCHEDULE SVant schedula based on previous 4 days load THRU MAY 14 (ALL) $(1,24)(-4)$

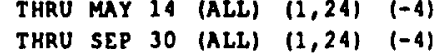

THRU DEC 31 (ALL) $(1,24)(-4)$.

VOPSCH SCHEDULE SVERT Oparation echedule

THRU DEC 31 (ALL) $(1,24)$ (VTYPE) ...

WINDOPER SCHEDULE SNo WIndow operation between $11 \mathrm{p} . \mathrm{m}$. and $6 \mathrm{a} . \mathrm{m}$,

THRU DEC 31 (ALL) $(1,6) \quad(0.0)$

$$
(7,23) \quad(1.0)
$$$$
\text { (24) } 10.01 \quad \ldots
$$

2C1 5 2ONE-CONTROL

DESIGN-COOL-T-78.

\begin{tabular}{|c|c|c|c|}
\hline THEROOM & & 2ONE & $\begin{array}{l}\text { THERMOSTAT-TYPE-TWO-POSITION . } \\
\text { ZONE-CONTROL-2CI } \\
\text { ZONE-TYPE CONDITIONED .. }\end{array}$ \\
\hline SBsmt & 5 BASEMENT & ZONE & ZONE-TYPE-UNCONDITIONED \\
\hline SGarage & S GARAGE & ZONE & ZONE-TYPE-UNCONDITIONED .. \\
\hline
\end{tabular}

COOL-TEMP-SCH-CTSCH

HEAT-TEMP-SCH-HTSCH

SYSCONTRL SYSTEM-CONTROL

MAX-SUPPLY - T-MAXTEMP

MIN-SUPPLY-T-50

\section{SYSAIR SYSTEM-AIR}

NATURAL-VENT-SCH-VOPSCH

VENT-TEMP-SCH-VTSCH

OPEN-VENT-SCH-WINDOPER

HOR-VENT-FRAC- 0.0

s assume $1 / 4$ of total window area opened for vent Ing,

5 and dlscharge coefflelent of 0.6

FRAC-VENT-AREA-0.018

VENT -METHOD-S-G

MAX-VENT-RATE-20

SYSEQP SYSTEM-EQUTPMENT

COOLING-EIR-CEIR

COIL-BF-CBF

COMPRESSOR-TYPE-SINGLE-SPEED

SFurn Furnace speciflcations

SFurn $\$$ FURNACE-AUX=O.

SFurn 5 FURNACE-HIR-FHIR $s$ duct losses In FHIR al ready

RESIDEN SYSTEM SYSTEM-TYPE-RESYS

SBSIT S ZONE-NAMES-ITHEROOM, BASEMENT

SGarage 5 ,GARAGE

SYSTEM-CONTROL-SYSCONTRL

SYSTEM-AIR-SYSAIR

SYSTEM-EQUI PMENT-SYSEQP

HEAT-SOURCE-GAS-FURNACE

RB1 REPORT-BLOCK

VARIABLE-TYPE - GLOBAL

VARIABLE-LIST - $(5,8,10)$

-

RB2 REPORT-BLOCK

VARIABLE-TYPE - RESIDEN

VARIABLE-LIST - $(5,6,8,33,47,48,61,62)$ $\cdots$

HRSCH SCHEDULE \$ Hourly report echedule THRU DEC 31 (ALL) $(1,24)$ (1)

SHR HOURLY-REPORT

REPORT-SCHEDULE - HRSCH

REPORT-BLOCK - (RB1, RB2)

END..

COMPUTE SYSTEMS ..

STOP .. 
IDAYK $-O$

5 CONTINUE

IF (ISUNUP .EO. O) GO TO 25

DELTA-DBT-65.0

IF (DELTA .GT. 0.00$)$ GO TO 10

HDH $=$ HDH+ABS (DELTA)

GO TO 20

$10 \mathrm{CDH}-\mathrm{COH}+\mathrm{DELTA}$

20 CONTINUE

IDAYH $-1 D A Y H+1$

25 IF (IHR .NE. 24) GO TO 70

CDDD-CDH/IDAYH

HDDD - HDH/IDAYH

IF (CDDD .LT. 5.00) GO TO 29

IF (SC.NE, O.80) GO TO 27

ICOUNT-ICOUNT+1

IF (ICOUNT . LE. A) GO TO 40

27 I HCOUNT-O

sc $=0.60$

Go To 70

29 IF (SC.NE. 0.60 ) 60 TO 30

IHCOUNT - I HCOUNT +1

IF (IHCOUNT .GE. A) 60 TO 30

SC- 0.60

ICOUNT $=0.0$
ICO To

$10 \mathrm{SC}=0.80$

70 CONTINUE

Y-sC

C PRINT $00, Y$, IMO, IDAY, IHR, CDDD, CDH, I COUNT, IHCOUN

80 FORMAT ' SHADING : ADD=',BF10.2)

END

END-FUNCTION

\section{FUNCTION NAME - FNDO}

LEVEL - UNDERGROUND-WALL ..

ASSIGN DOY-IDOY UGFO-QUGF UGWQ-QUGW .

ASSIGN QTABL - TABLE

$(0,-12008.7)(1,-12119.2)(2,-12274.9)(3,-12414.2)(4,-12538.4)$ $(5,-12647.6)(6,-12740.2)(7,-12817.7)(8,-12877.2)(9,-12921.5)$ $(10,-12949.1)(11,-12960.1)(12,-12954.2)(13,-12931.6)(14,-12892.1)$ $(15,-12837.2)(16,-12765.4)(17,-12676.6)(18,-12572.3)(19,-12452.3)$ $(20,-12316.7)(21,-12166.7)(22,-12002.4)(23,-11823.7)(24,-11630.6)$ $(20,-12316.7)(21,-12166.7)(22,-12002.4)(23,-11823.7)(24,-11630.6)$
$(25,-11424.5)(26,-11206.7)(27,-10973.8)(28,-10733.2)(29,-10481.5)$ $(30,-10218.1)(31,-9943.7)(32,-9665.6)(33,-9376.4)(34,-9081.0)$ $(35,-8777.9)(36,-8469.8)(37,-8158.1)(38,-7841.6)(39,-7521.5)$ $(40,-7200.5)(41,-6877.4)(42,-6553.6)(43,-6230.4)(44,-5907.8)$ $(45,-5588.6)(46,-5271.4)(47,-4957.6)(48,-4650.1)(49,-4346.0)$
$(50,-4049.6)(51,-3759.4)(52,-3470.3)(53,-3204.9)(54,-2940.7)$ $(55,-2686.4)(56,-2443.0)(57,-2210.9)(58,-1990.9)(59,-1783.2)$ $(60,-1588.8)(61,-1407.9)(62,-1241.1)(63,-1089.0)(64,-951.6)$ $(65,-829.6)(66,-723.2)(67,-632.8)(68,-558.5)(69,-500.6)$ $(70,-459.2)(71,-434.3)(72,-426.2)(73,-434.8)(74,-460.0)$ $(75,-501.9)(76,-560.3)(77,-635.0)(78,-725.9)(79,-832.71$ $\left(80,-955.21\left(81_{0}-1092.91(82,-2245.5)(103,-1422.7)(84,-1594.01\right.\right.$

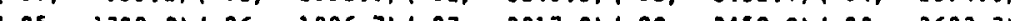
$(90,-2947.1)(91,-3212.0)(92,-3405.9)(93,-3767.5)(94,-4058.11$ $(95,-4355.0)(96,-1658.2)(97,-4966.3)(98,-5279.5)(99,-5596.1)$ $(100,-5916.4)(101,-6238.7)(102,-6561.9)(103,-6885.8)(104,-7207.7)$ $(105,-7530.5)(106,-7849.8)(107,-8165.6)(108,-8478.1)(109,-8785.7)$ $(110,-9087.1)(111,-9383.6)(112,-9671.1)(113,-9952.2)(114,-10224.3)$ $(115,-10485.8)(116,-10738.2)(117,-10980.0)(118,-11209.9)(119,-11428.9)$ $(120,-11633,4)(121,-11825.6)(122,-11947.1)$

Calculate

WCEK - DOY 13.0

UGWQ $=0.0$

UGFO - PWL (OTABL, WEEK)

C PRINT 10, DOY, WEEK, UGWQ, UGFO

10 FORMAT (' FNDQ', 4F10.2)

END-FUNCTION

COMPUTE LOADS.

POST-PROCESSOR PARTIAL ..

$2 *(*) \cdot(*) *(*) *(*) *(*) *(*) *(*) \cdot(*) *(*) *(*) *(*) *(*) \cdot(*) *(*) *(*) *$ $s *(*)+(*) *(*) *(*) *(*) \quad(*) *(*) *(*) *(*) *(*) *$ $s \cdot(\cdot)^{*}(*) *(*) \cdot(\cdot) \cdot(*)$ Flle name:sYs.PROD $(*) \cdot(\cdot) \cdot(\cdot) \cdot(\bullet) \cdot(*)$ $s *(*) \cdot(*) *(*) *(*) *(*)$ Date: Nov $31986(*) *(*) \cdot(*) *(*) \cdot(*)$ $s *(*) \cdot(*) \cdot(*) \cdot(*) *(*) \quad(*) *(*) *(*) \cdot(*) *(*)$ $s *(*) *(*) *(*) *(*) *(*) *(*) *(*) *(*) *(*) *(*) *(*) *(*) *(\cdot) *(*) *(*)$

\section{INPUT SYSTEMS}

TITLE LINE-1 * CN1C- $C$ (13-32-00-dD1) BEAT

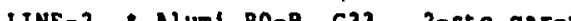

LINE-3 - Chlcago IL TMY Furn/AC

LINE-4

LINE-5

DIAGNOSTIC CAUTIONS ECHO .

SYSTEMS-REPORT

HOURIY-DATA-SAVE - YES

SUMARY - (SS-A, SS-B, SS-C, SS-F, SS-H, SS-I) .

PARAMETER
HEATSET-70
SOOLSET-78




\section{APPENDIX D: B1+ PROTOTYPE COOLING LOAD SENSITIVTTY STUDY}

The B1+ prototype was developed to include a series of buildings in the database with peak cooling loads above three tons $(36,000 \mathrm{Btu} / \mathrm{hr})$. It is an enlarged version of the standard B1 prototype, which was defined as built between 1950 and 1969, and had been been retrofitted with insulation, weatherstripping, and window treatments as appropriate for each climate. The goal of the sensitivity analysis described bere was to determine the effect of important building operating assumptions used in the simulations on the magnitude of the peak and annual cooling loads.

As described in the main body of the report, the configuration and thermal characteristics of the B1 houses were determined in the previous study using the 1980 Residential Energy Consumption Survey (RECS) data tape. To develop a prototype with large loads, we increased the floor area of the prototypes by twice the standard deviation in building floor area. All other building characteristic and operation inputs were left unchanged except for increases in internal gains from lighting and some small appliances.

\section{SENSITIVITIES}

In order to determine the sensitivity of the loads in these houses with respect to infiltration levels, ventilation schedules (no ventilation with windows closed vs. typical ventilation schedule based on outside temperature and latent enthalpy bours), and temperature setpoints and setback and setups, we performed a series of sensitivity runs using DOE-2.1D. These sensitivity tests were conducted on two base cities (Chicago and Fort Worth). The base case conditions are given in Table 1.

Table 1. Base Heating and Cooling Loads for B1+ Prototypes

\begin{tabular}{|l|c|c|cc|cc|}
\hline & Number & Area & \multicolumn{2}{|c|}{ Cooling Loads } & \multicolumn{2}{|c|}{ Heating Loads } \\
Location & Stories & $\left(\mathrm{ft}^{2}\right)$ & $(\mathrm{MMBtu})$ & $\begin{array}{c}\text { Peak } \\
(\mathrm{kBtu})\end{array}$ & $\begin{array}{c}\text { Annual } \\
(\mathrm{MMBtu})\end{array}$ & $\begin{array}{c}\text { Peak } \\
(\mathrm{kBtu})\end{array}$ \\
\hline Chicago & 1 & 3220 & 11.8 & 37.3 & 144.6 & 91.1 \\
Fort Worth & 1 & 2638 & 36.8 & 38.6 & 34.9 & 45.4 \\
\hline
\end{tabular}

Notes: Base conditions: ELF $=0.0006$ (infiltration); $78 \mathrm{~F}$ cooling setpoint; no cooling setup.

The parameters chosen for the sensitivity tests were as follows: infiltration: several effective leakage fractions (.0005, .0006 - the base case, .0007 , and .008$)$; ventilation: no venting 
and base case ventilation schedule; and air-conditioning settings: $76 \mathrm{~F}$ with no setup; $78 \mathrm{~F}$ with no setup (base case), $78 \mathrm{~F}$, and $80 \mathrm{~F}$ with setups of $80 \mathrm{~F}, 82 \mathrm{~F}$, and $84 \mathrm{~F}$. We also conducted some combined parametric simulations with different ranges of infiltration rate, ventilation, and temperature settings and setbacks/ups. The results of these sensitivity tests are presented in the tables for both the Chicago and Fort Worth houses. We also include graphic presentations of the one-dimensional and multidimensional sensitivity results for both heating and cooling in Chicago and Fort Worth.

\section{SUMMARY}

The sensitivities provide some interesting results. The effect of changing infiltration rates on annual and peak beating and cooling loads is generally linear. For Chicago, the change in annual load per change in effective leakage area (per 1/1000) is $6.5 \%$ for heating and 4.2\% for cooling. Similar changes for Fort Worth are $7.5 \%$ for heating and $4.5 \%$ for cooling. For peak loads, the changes are $8.8 \%$ heating and $5.1 \%$ cooling in Chicago and $5.3 \%$ heating and $5.4 \%$ cooling in Fort Worth. In general, the changes were not significant for this range of infiltration levels.

The ventilation sensitivity also showed fairly little difference between the ventilation and no ventilation cases for annual loads and does not affect peak loads. The reduction in annual cooling load due to the ventilation schedule is calculated to be about $1 \mathrm{MMBtu} / \mathrm{yr}$, or $9 \%$ for Chicago and 5\% for Fort Worth. The most sensitive parameter in our analysis was airconditioner setpoints and setups, (i.e, setting temperature higher during unoccupied periods) usually during daytime hours (8:00 a.m.- 5:00 p.m.). Using the setup or setting the setpoint to a slightly higher temperature level causes substantial decreases in annual cooling loads. For Chicago, using a setup of $84 \mathrm{~F}$ reduces the cooling loads by $25 \%$, while setting the cooling setpoint to $80 \mathrm{~F}$ with an $84 \mathrm{~F}$ setup reduces cooling loads by $50 \%$. We found similar cooling load reductions for Fort Worth. The results for Fort Worth show an $18 \%$ reduction for $84 \mathrm{~F}$ setup and a $33 \%$ reduction for an $80 \mathrm{~F}$ setpoint with an $84 \mathrm{~F}$ setup.

For peak loads, increasing the thermostat setpoint by $2 \mathrm{~F}$ reduces peak cooling by 4.4 $\mathrm{kBtu}(12 \%)$ in Chicago and $2.5 \mathrm{kBtu}(7 \%)$ in Fort Worth. Setups, while reducing the annual loads, have a large effect on peak loads in Chicago, with an $84 \mathrm{~F}$ setup increasing the peak load by $35 \%$. The loads in Fort Worth are not so drastically affected, showing a $7 \%$ increase in peak load.

All of the results are shown in Tables 2 through 5. 
Table 2. Summary of Simple Parametric Simulations for Prototypical B1+ House in Chicago

\begin{tabular}{|ll|cc|cc|cc|}
\hline \multirow{2}{*}{ Measure } & Case & \multicolumn{2}{|c|}{ Load (MMBtu) } & \multicolumn{2}{c|}{ Load $\left(\mathbf{k B t u} / \mathrm{ft}^{2}\right)$} & \multicolumn{2}{c|}{ Peak Load (kBtu) } \\
\hline Base Case $^{*}$ & & 144.6 & 11.8 & 44.9 & 3.7 & 91.1 & 37.3 \\
\hline Infiltration & 0.0005 elf & 135.0 & 11.3 & 41.9 & 3.5 & 83.1 & 35.4 \\
& 0.0007 elf & 154.1 & 12.3 & 47.9 & 3.8 & 99.6 & 39.2 \\
& 0.0008 elf & 163.6 & 12.9 & 50.8 & 4.0 & 107.6 & 41.9 \\
\hline AC Setting & $76(76) * *$ & 144.7 & 17.2 & 44.9 & 5.3 & 91.1 & 41.7 \\
& $76(84)$ & 144.6 & 12.3 & 44.9 & 3.8 & 91.1 & 52.8 \\
& $78(84)$ & 144.5 & 8.8 & 44.9 & 2.7 & 91.1 & 50.2 \\
& $80(80)$ & 144.4 & 7.6 & 44.9 & 2.3 & 91.1 & 33.0 \\
& $80(84)$ & 144.4 & 5.9 & 44.8 & 1.8 & 91.1 & 42.0 \\
& $82(82)$ & 144.4 & 4.4 & 44.8 & 1.4 & 91.1 & 29.4 \\
& $82(84)$ & 144.3 & 3.8 & 44.8 & 1.2 & 91.1 & 32.5 \\
\hline Ventilation & No Venting & 144.2 & 12.9 & 44.8 & 4.0 & 91.1 & 37.3 \\
\hline
\end{tabular}

- Base Case is for the prototype model with the following properties: AC setting $78 \mathrm{~F}$; AC setup $78 \mathrm{~F}$; infiltration 0.0006 elf; with venting.

** In $A(B), A$ denotes the cooling setpoint and $B$ denotes the setup temperature.

Table 3. Summary of Combined Parametric Simulations for Prototypical B1 + House in Chicago

\begin{tabular}{|lccc|cc|cc|cc|}
\hline \multicolumn{4}{|c|}{ Measure } & \multicolumn{2}{|c|}{ Load (MMBtu) } & \multicolumn{2}{|c|}{ Load (kBtu/ft $\left.{ }^{2}\right)$} & \multicolumn{2}{|c|}{ Peak Load (kBtu) } \\
Infiltration Setpoint & Setup Ventilation & Heat & Cool & Heat & Cool & Heat & Cool \\
\hline 0.0006 elf & 78 & 78 & No Venting & 144.2 & 12.9 & 44.8 & 4.0 & 91.1 & 37.3 \\
0.0006 elf & 78 & 78 & Venting & 144.6 & 11.8 & 44.9 & 3.7 & 91.1 & 37.3 \\
0.0005 elf & 78 & 78 & Venting & 135.0 & 11.3 & 41.9 & 3.5 & 83.1 & 35.4 \\
0.0005 elf & 78 & 84 & Venting & 135.0 & 8.5 & 41.9 & 2.6 & 83.1 & 46.3 \\
0.0005 elf & 80 & 80 & Venting & 134.9 & 7.2 & 41.9 & 2.2 & 83.1 & 31.4 \\
0.0005 elf & 80 & 84 & Venting & 134.9 & 5.7 & 41.9 & 1.8 & 83.1 & 40.0 \\
\hline
\end{tabular}


Table 4. Summary of Simple Parametric Simulations for Prototypical B1+ House in Forth Worth

\begin{tabular}{|ll|cc|cc|cc|}
\hline \multirow{2}{*}{ Measure } & Case & \multicolumn{2}{|c|}{ Load (MMBtu) } & \multicolumn{2}{c|}{ Load (kBtu/ft $\left.{ }^{2}\right)$} & \multicolumn{2}{c|}{ Peak Load (kBtu) } \\
\hline Base Case* & & 34.9 & 36.8 & 13.2 & 14.0 & 45.4 & 38.6 \\
\hline Infiltration & 0.0005 elf & 32.3 & 35.1 & 12.3 & 13.3 & 43.1 & 36.4 \\
& 0.0007 elf & 37.5 & 38.4 & 14.2 & 14.6 & 47.8 & 40.7 \\
& 0.0008 elf & 40.1 & 40.0 & 15.2 & 15.2 & 50.2 & 42.8 \\
\hline AC Setting & $76(76)^{* *}$ & 35.1 & 46.4 & 13.3 & 17.6 & 45.4 & 40.9 \\
& $76(78)$ & 34.9 & 36.5 & 13.2 & 13.9 & 45.4 & 41.2 \\
& $78(84)$ & 34.8 & 30.1 & 13.2 & 11.4 & 45.4 & 41.3 \\
& $80(80)$ & 34.8 & 28.7 & 13.2 & 10.9 & 45.4 & 35.9 \\
& $80(84)$ & 34.7 & 24.6 & 13.2 & 9.3 & 45.4 & 38.9 \\
& $82(82)$ & 34.7 & 21.8 & 13.2 & 8.3 & 45.4 & 33.1 \\
& $82(84)$ & 34.7 & 19.9 & 13.2 & 7.5 & 45.4 & 34.1 \\
\hline Ventilation & No Venting & 34.6 & 38.7 & 13.1 & 14.7 & 45.4 & 38.6 \\
\hline
\end{tabular}

- Base Case is for the prototype model with the following properties: AC setting $78 \mathrm{~F}$; AC setup $78 \mathrm{~F}$; infiltration 0.0006 elf; with venting.

* In $A(B), A$ denotes the cooling setpoint and $B$ denotes the setup temperature.

Table 5. Summary of Combined Parametric Simulations for Prototypical B1+ House in Forth Worth

\begin{tabular}{|lccc|cc|cc|cc|}
\hline \multicolumn{4}{|c|}{ Measure } & \multicolumn{2}{|c|}{ Load $(\mathrm{MMBtu})$} & \multicolumn{2}{|c|}{ Load $\left(\mathrm{kBtu} / \mathrm{ft}^{2}\right)$} & \multicolumn{2}{|c|}{ Peak Load (kBtu) } \\
Infiltration & Setpoint & Setup & Ventilation & Heat & Cool & Heat & Cool & Heat & Cool \\
\hline 0.0006 elf & 78 & 78 & No Venting & 34.6 & 38.7 & 13.1 & 14.7 & 45.4 & 38.6 \\
0.0006 elf & 78 & 78 & Venting & 34.9 & 36.8 & 13.2 & 14.0 & 45.4 & 38.6 \\
0.0005 elf & 78 & 78 & Venting & 32.3 & 35.1 & 12.3 & 13.3 & 43.1 & 36.4 \\
0.0005 elf & 78 & 84 & Venting & 32.2 & 28.9 & 12.2 & 11.0 & 43.1 & 38.7 \\
0.0005 elf & 80 & 80 & Venting & 32.2 & 27.4 & 12.2 & 10.4 & 43.1 & 33.9 \\
0.0005 elf & 80 & 84 & Venting & 32.2 & 23.6 & 12.2 & 9.0 & 43.1 & 36.8 \\
\hline
\end{tabular}




\section{APPENDIX E: PEAK COOLING LOAD SENSITIVITY ANALYSIS}

We analyzed several issues related to prototype peak cooling loads in the single family database simulation.

\section{PEAK WEATHER CONDITIONS}

For example, it was noted that a "cold" location like Chicago had higher peak cooling loads than a "hot" location like Miami. These peak loads are determined by peak summer weather conditions that are unrelated to either the length of the cooling season or average summer temperatures. To clarify this distinction, we suggested that we show the coincident weather conditions when peak cooling loads occur. In fact, the maximum temperature and humidity ratio on the peak cooling day are more relevant as weather indicators. The reason is that buildings typically take several hours to respond to peak weather conditions, so that the coincident conditions at the peak hour can be misleading. Table 1 gives the results for selected buildings and locations, along with the design-day conditions from the ASHRAE Handbook of Fundamentals.

Table 1. Comparison of the Peak Weather Conditions from Weather Tapes to ASHRAE Design-Day Conditions

\begin{tabular}{|c|c|c|c|c|c|c|c|c|}
\hline \multirow[b]{2}{*}{ City } & \multicolumn{2}{|c|}{ ASHRAE $(97.5 \%)^{*}$} & \multicolumn{3}{|c|}{ Concident to peak load } & \multicolumn{3}{|c|}{ Max. on peak cooling day } \\
\hline & $\begin{array}{c}\text { Dry } \\
\text { Bulb } \\
\left({ }^{\circ} \mathrm{F}\right)\end{array}$ & $\begin{array}{l}\text { Wet } \\
\text { Bulb } \\
\left.{ }^{\circ} \mathrm{F}\right)\end{array}$ & $\begin{array}{l}\text { Dry } \\
\text { Bulb } \\
\left({ }^{\circ} \mathrm{F}\right)\end{array}$ & $\begin{array}{l}\text { Wet } \\
\text { Bulb } \\
\left({ }^{\circ} \mathrm{F}\right)\end{array}$ & $\begin{array}{l}\text { Date } \\
\text { and } \\
\text { Hour }\end{array}$ & $\begin{array}{l}\text { Dry } \\
\text { Bulb } \\
\left({ }^{\circ} \mathrm{F}\right)\end{array}$ & $\begin{array}{c}\text { Wet } \\
\text { Bulb } \\
\left({ }^{\circ} \mathrm{F}\right)\end{array}$ & $\begin{array}{l}\text { Date } \\
\text { and } \\
\text { Hour }\end{array}$ \\
\hline Chicago & 91 & 74 & 90 & 74 & $5 / 12(18)$ & 91 & 73 & $5 / 12(15)$ \\
\hline Miami & 90 & 77 & 87 & 78 & $9 / 10(18)$ & 89 & 80 & $9 / 10(13)$ \\
\hline Phoenix & 107 & 71 & 103 & 72 & $7 / 3(19)$ & 103 & 72 & $7 / 3(16)$ \\
\hline Seattle & 82 & 66 & 89 & 68 & $8 / 1(16)$ & 89 & 68 & $8 / 1(16)$ \\
\hline
\end{tabular}

- Source : ASHRAE Handbook, 1977 Fundamentals

Table 1 shows several things: (1) Peak cooling conditions do not vary greatly between cities despite differences in the lengths of their cooling seasons. For example, the peak drybulb temperature in Chicago is higher than that in Miami using any of the three weather criteria, while the wetbulb is only 3 to 7 degrees lower. (2) The maximum temperatures on the peak cooling day are only slightly higher than the coincident temperatures, despite time differences of 3 to 5 hours. This suggests that peak cooling loads occur on days when temperatures remain high for many hours. (3) The peak temperatures on the weather tapes are very similar to 
ASHRAE design-conditions. This indicates that the relatively small peak loads in the data base cannot be attributed to unrealistically mild data on the weather tapes. The following paragraph discusses the issue of peak loads in more detail.

\section{PEAK COOLING LOADS}

The peak cooling loads on the data base are significantly lower than both the earlier data base results and typical air-conditioner capacities. For example, it was noted that only some of the poorly insulated old and large prototype houses (A, B1+ and D+), and none of the others, had peak loads in the three-ton $(36,000 \mathrm{Btu})$ range found in typical air-conditioners.

The differences from the earlier data can be attributed to the following modeling improvements that tend to lower the calculated cooling loads : 1 . better "weighting-factor" calculations in DOE-2.1D to account for the effects of thermal mass, 2. varying infiltration rates depending on outdoor wind speed and temperature (Sherman-Grimsrud model) instead of fixed air-change rates, 3. window shading schedules varying with season instead of constant all year, 4. windows assumed open for natural ventilation instead of of closed at all times, and 5. lower heat gains from occupants and appliances. A quantitative assessment of the individual impacts of these modeling differences would require diagnostic computer simulations and further analysis.

It is important that the data base peak loads not be misinterpreted as design loads. The data base loads do not include duct losses or sizing factors to account for unexpected conditions. In practice, designers typically add a duct loss factor of 10 to $20 \%$, a sizing factor of 1.15 for cooling and $\mathbf{1 . 2 0}$ for heating, and then select the equipment of the next available size.* To compare and contrast these differences, we have explored the following:

a. Calculate peak loads assuming design-day conditions. We checked the equipment capacities calculated by DOE-2 based on the yearly weather data against design-day calculations using ASHRAE 97.5\% design conditions. This was done for both Phoenix and Miami. For Phoenix, using the design-day data resulted in smaller peak loads. For Miami, similar cooling capacities are picked up in both methods. This clearly shows that there was no peak smoothing due to the weather data used in the DOE-2 simulations. This observation is consistent with the analysis of peak weather conditions described earlier in this section.

b. Calculate peak loads using standard ASHRAE design procedures. Since the above calculation was still done by the DOE-2 program, we used the Comply-24 computer program (copyright Mike Gabel Associates, 1984) to do standard ASHRAE design calculations for several of the prototypical houses. The ASHRAE design calculation for residential buildings is identical to the Manual-J used by contractors for residential air-conditioner sizing. Since the ASHRAE design calculation accounts for latent loads only as a fractional value of the sensible

\footnotetext{
- Adrian Tuluca, Steven Winters Associates, personal communication.
} 
load, we assumed typical values of 0.20 for Chicago, Seattle and Phoenix, and 0.30 for humid Miami. We also used a typical duct loss factor of $10 \%$ and then added to the Comply-24 results a sizing factor of 1.15. Table 2 compares the results from these ASHRAE design calculations to building peak loads from the data base. The ASHRAE Design Loads are shown both with and without duct losses and sizing factors.

Table 2. Loads firom ASHRAE Design Calculations

Compared to Building Peak Loads from the Data Base

\begin{tabular}{|c|c|c|c|c|c|}
\hline \multirow[b]{2}{*}{ Location } & \multirow[b]{2}{*}{$\begin{array}{c}\text { House } \\
\text { Size } \\
\left(\mathrm{ft}^{2}\right)\end{array}$} & \multirow[b]{2}{*}{$\begin{array}{c}\text { House } \\
\text { Type }\end{array}$} & \multicolumn{2}{|c|}{ ASHRAE Design Loads } & \multirow{2}{*}{$\begin{array}{c}\text { Peak Loads } \\
\text { from DOE-2 } \\
\text { data base } \\
(\mathrm{kBtu} / \mathrm{hr})\end{array}$} \\
\hline & & & $\begin{array}{c}\text { w/o duct loss } \\
\& \text { size factor } \\
\text { (kBtu/hr) }\end{array}$ & $\begin{array}{c}\text { w/ duct loss } \\
\& \text { size factor } \\
(\mathrm{kBtu} / \mathrm{hr})\end{array}$ & \\
\hline Chicago & 2420 & D & 27.4 & 34.6 & 26.3 \\
\hline Miami & 1830 & D & 27.1 & 34.3 & 19.2 \\
\hline Phoenix & 1880 & D & 28.8 & 36.4 & 28.8 \\
\hline
\end{tabular}

c. Checked the impact of modified operations on building peak loads. Another consideration is that in our building models the air-conditioner is never turned off nor is there a thermostat setup during the day. Since many houses are not occupied during the day, their occupants will typically turn the equipment off when they leave in the morning, and then it back on when they return. This causes a larger peak load because the equipment will then have to cool down the house in the late afternoon. Because of the high probability of such transient loads, contractors generally add a safety factor into their design calculations. To investigate their impact on peak cooling loads, we made a series of simulations using such a modified schedule. At the same time, we disabled the natural ventilation routine for those hours when the people are not home. Table 3 shows the effect of this modified schedule on peak cooling loads.

It becomes clear looking at Table 3 that a $15-20 \%$ safety margin makes sense when sizing the cooling equipment. Based on discussions with practicing architects and engineers, such a "sizing factor" is indeed used by many people in the field.

Concluding remarks on peak loads : In the course of this investigation, we talked to three independent sources $t$, all of whom stated that residential air-conditioner sizing was inexact and follows tradition rather than rigorous calculations. The comparison of weather tape to

† Adrian Tuluca, Steven Winters Ascociates; Bruce Birdsall, Lawrence Berkeley Laboratory; Jim Brodrick, Pacific Northwest Laboratory, formerly with Carrier. 
Table 3. Percent Increase in Peak Cooling Loads due to Modified Schedule

\begin{tabular}{|lc|lc|}
\hline City & $\begin{array}{c}\text { Percent increase } \\
\text { in peak cool. load }\end{array}$ & City & $\begin{array}{c}\text { Percent increase } \\
\text { in peak cool. load }\end{array}$ \\
\hline Boston & 20 & Fort Worth & -4 \\
New York & 25 & New Orleans & 10 \\
Chicago & 20 & Denver & 28 \\
Minneapolis & 13 & Albuquerque & 42 \\
Kansas & 10 & Phoenix & 18 \\
Washington & 10 & Seattle & 25 \\
Atlanta & 16 & San Francisco & 20 \\
Miami & 0 & Los Angeles & 43 \\
\hline
\end{tabular}

design-day climate data indicates that the data base peak loads are not being "damped" by the weather tape conditions. The comparison of the peak loads to ASHRAE design loads shows that the two are roughly comparable if the safety factors in the design load calculations are eliminated. However, the spot check of a plausible modification to the operating condition shows that such safety factors are prudent and necessary.

The ultimate test of the validity of the simulated loads is that they compare well with metered and billed data. This section confirms the quality of the data. The modeling improvements inherent in version DOE 2.1D were made to improve the realism of the model and improve the validity of the results. The modeling enhancements were made after significant peer review. 


\section{APPENDIX F: LATENT LOAD SENSITIVITY ANALYSIS}

We analyzed the impact of different latent load assumptions on the simulated prototype cooling loads. LBL was asked by GRI to verify the latent loads in the data base results, as well as the possibility of window venting introducing additional latent load.

a. Comparison of data base latent loads to measured results. We contacted the Florida Solar Energy Center (FSEC) for data on latent cooling loads in single-family residences The only measured data which they have analyzed are from an unoccupied townhouse in Florida.* In this building, latent loads ranged from 25 to $37 \%$ of the total cooling equipment loads, with an average of $30 \%$. For the data base simulations in Miami, the latent fraction ranges from $25 \%$ in the A house to $30 \%$ in the D house, which is slightly on the low side of the measured data. In comparison, data from the GRI research house suggests that latent loads are even smaller. For a cooling system operating at high speed and outdoor conditions of 78 to $85^{\circ} \mathrm{F}$ and 75 to $87 \%$ relative humidity, the latent fraction is only 13 to $15 \% . \dagger$

The two sources of latent loads are infiltration and internal gains. The DOE-2 "Loads" output for the Miami $\mathrm{D}$ house shows that infiltration dominates, accounting for $87 \%$ of the latent load. However, we re-ran the data base $D$ prototypes with increased latent internal gains to study the effects of our internal gains inputs. FSEC provided latent gains assumptions they used in a previous GRI report $¥$ which indicate our latent internal gains assumptions may be on the low side. They assumed higher latent gains from occupants (4490 Btu/day vs. 2290 Btu/day) and included latent gains from plants and other bousehold activities using water (3000 Btu/day). Thus, for the sensitivity runs we increased the latent internal gains from approximately 11,000 to 20,000 Btu/day. The results for Miami and Phoenix are presented below. In Miami, the total cooling load and the latent load increased by only $0.9 \mathrm{MMBtu} / \mathrm{yr}$. The latent fraction thus increases from $30.1 \%$ to $32.0 \%$. In Phoenix, an arid climate, the effect on total cooling load was also very small, yet the latent fraction increased from $8.7 \%$ to $10.8 \%$ (see Table 4).

b. Effect of different window venting criteria on latent loads. The DOE-2 program allows the user to specify one of three choices of window operations: temperature-control, enthalpic-control, or no venting at all (i.e., windows always closed). Temperature venting is done when outside conditions are cooler than indoor, whereas enthalpic venting is done when

\footnotetext{
- Danny Parker, Florida Solar Energy Center, personal communication.

† William Bassett, Gas Research Institute, personal communication. For information on the GRI Research House, see "GRI's Research House Utilization Plan," Topical Report GRI-91/0035, Chicago, IL.

‡ "Latent and Sensible Load Distributions in Conventional and Energy Efficient Residences", GRI Contract No. 5082-243-0727.
} 
Table 4. Effect of Increased Latent Internal Gains on DOE-2 Calculated Heating and Cooling Laads

\begin{tabular}{|lcccc|}
\hline City & $\begin{array}{c}\text { Latent } \\
\text { Gains(Btu/day) }\end{array}$ & $\begin{array}{c}\text { Total Cooling } \\
\text { Load(MMBtu) }\end{array}$ & $\begin{array}{c}\text { Latent Cooling } \\
\text { Load(MMBtu) }\end{array}$ & $\begin{array}{c}\text { Latent } \\
\text { Fraction }\end{array}$ \\
\hline Miami & 11,011 & 35.2 & 10.6 & $30.1 \%$ \\
& 20,000 & 36.1 & 11.5 & $32.0 \%$ \\
\hline Phoenix & 11,011 & 30.0 & 2.6 & $8.7 \%$ \\
& 20,000 & 30.7 & 3.3 & $10.8 \%$ \\
\hline
\end{tabular}

outside conditions are both cooler and less humid. Table 5 demonstrates the effect of this variable on building heating and cooling loads. The peak loads are not affected at all by this variable.

Table 5. Effect of Different Types of Window Ventilation of DOE-2 Calculated Heating and Cooling Laads

\begin{tabular}{|c|c|c|c|c|}
\hline City & $\begin{array}{l}\text { Venting } \\
\text { Type }\end{array}$ & $\begin{array}{c}\text { Heating } \\
\text { Load(MMBtu) }\end{array}$ & $\begin{array}{l}\text { Total Cooling } \\
\text { Load(MMBtu) }\end{array}$ & $\begin{array}{l}\text { Latent Cooling } \\
\text { Load(MMBtu) }\end{array}$ \\
\hline \multirow[t]{3}{*}{ Miami } & No Venting & 1.3 & 36.6 & 10.9 \\
\hline & Enthalpic Venting & 1.6 & 35.2 & 10.6 \\
\hline & Temperature Venting & 1.6 & 31.3 & 9.5 \\
\hline \multirow[t]{3}{*}{ Phoenix } & No Venting & 6.2 & 32.2 & 2.6 \\
\hline & Enthalpic Venting & 6.6 & 30.0 & 2.6 \\
\hline & Temperature Venting & 6.6 & 29.7 & 2.5 \\
\hline
\end{tabular}




\section{BINNED RESULTS}


APPENDIX G: MONTHLY DOMESTIC HOT WATER LOADS BY CITY

\begin{tabular}{|c|c|c|c|c|c|c|c|c|c|c|c|c|c|}
\hline \multirow[b]{2}{*}{ REGION/City } & \multicolumn{13}{|c|}{ Monthly Hot Water Loads (MMBtu) } \\
\hline & Jan & Feb & Mar & Apr & May & Jun & Jul & Aug & Sep & Oct & Nov & $\operatorname{Dec}$ & Year \\
\hline NOR & & & & & & & & & & & & & \\
\hline Boston & 1.75 & 1.57 & 1.67 & 1.50 & 1.43 & 1.28 & 1.27 & 1.29 & 1.31 & 1.47 & 1.55 & 1.70 & 17.81 \\
\hline New York & 1.65 & 1.47 & 1.56 & 1.40 & 1.33 & 1.19 & 1.18 & 1.19 & 1.22 & 1.38 & 1.45 & 1.60 & 16.63 \\
\hline NORTH CEN & & & & & & & & & & & & & \\
\hline Chicago & 1.74 & 1.55 & 1.63 & 1.45 & 1.36 & 1.21 & 1.20 & 1.22 & 1.26 & 1.44 & 1.52 & 1.68 & 17.27 \\
\hline Minneapolis & 1.97 & 1.74 & 1.81 & 1.59 & 1.47 & 1.30 & 1.29 & 1.33 & 1.40 & 1.62 & 1.73 & 1.92 & 19.18 \\
\hline Kansas City & 1.62 & 1.44 & 1.51 & 1.33 & 1.24 & 1.10 & 1.10 & 1.13 & 1.18 & 1.35 & 1.43 & 1.58 & 16.03 \\
\hline SOUTH & & & & & & & & & & & & & \\
\hline Washington & 1.58 & 1.41 & 1.48 & 1.33 & 1.25 & 1.13 & 1.12 & 1.14 & 1.18 & 1.33 & 1.40 & 1.54 & 15.90 \\
\hline Atlanta & 1.33 & 1.18 & 1.25 & 1.13 & 1.08 & 0.99 & 0.99 & 1.02 & 1.04 & 1.16 & 1.20 & 1.30 & 13.68 \\
\hline Miami & 0.91 & 0.82 & 0.89 & 0.83 & 0.83 & 0.78 & 0.79 & 0.80 & 0.79 & 0.84 & 0.84 & 0.90 & 10.03 \\
\hline Fort Worth & 1.24 & 1.10 & 1.16 & 1.04 & 0.98 & 0.89 & 0.89 & 0.90 & 0.93 & 1.05 & 1.10 & 1.21 & 12.50 \\
\hline New Orleans & 1.13 & 1.00 & 1.07 & 0.98 & 0.95 & 0.88 & 0.89 & 0.90 & 0.92 & 1.01 & 1.03 & 1.11 & 11.86 \\
\hline WEs & & & & & & & & & & & & & \\
\hline Denv & 1.79 & 1.59 & 1.67 & 1.50 & 1.43 & 1.29 & 1.29 & 1.32 & 1.36 & 1.53 & 1.60 & 1.75 & 18.12 \\
\hline Albug & 1.44 & 1.28 & 1.34 & 1.19 & 1.13 & 1.02 & 1.02 & 1.05 & 1.09 & 1.23 & 1.29 & 1.41 & 14.48 \\
\hline Phoenix & 1.22 & 1.08 & 1.13 & 1.01 & 0.95 & 0.85 & 0.85 & 0.87 & 0.90 & 1.02 & 1.08 & 1.19 & 12.17 \\
\hline Seattle & 1.58 & 1.42 & 1.53 & 1.42 & 1.40 & 1.30 & 1.32 & 1.33 & 1.33 & 1.43 & 1.45 & 1.56 & 17.10 \\
\hline San Fra & 1.36 & 1.23 & 1.35 & 1.28 & 1.29 & 1.22 & 1.25 & 1.24 & 1.22 & 1.29 & 1.27 & 1.35 & 15.36 \\
\hline Los Angeles & 1.25 & 1.13 & 1.24 & 1.18 & 1.18 & 1.12 & 1.13 & 1.12 & 1.10 & 1.16 & 1.15 & 1.22 & 13.99 \\
\hline
\end{tabular}




\section{APPENDIX H: BINNED BUILDING LOADS}

\section{BUILDING LOADS BINNED BY TEMPERATURE AND HUMIDITY RATIO}

These tables show the total heating, total cooling, and latent cooling loads in kBtu and the number of full-load hours for each building by 5 degree temperature bins for heating, and by 5 degree temperature and .002 humidity ratio bins for cooling. The midpoints of the bins

are identified on the left of each table for the one-dimensional temperature bins for heating loads, or on the left (for temperatures) and across the top (for bumidity ratios) of each table for the two-dimensional bins for cooling loads. For example, the temperature bin 62.5 includes all loads for temperatures between 60 and $65 \mathrm{~F}$; likewise, the humidity bin 0.003 includes all loads when humidity ratios are between 0.002 and 0.004 .

\section{BUILDING LOADS BINNED BY TEMPERATURE AND HOUR OF DAY}

These tables show the heating and cooling loads in $\mathrm{kBtu}$ for each building binned twodimensionally by 5 degree temperatures and the hour of day. The midpoints of the temperature bins are identified on the left of the tables. For example, the temperature bin 62.5 includes loads when outdoor temperatures are between 60 and $65 \mathrm{~F}$. The hour of day bins are identified across the top of the tables, with the 25 th column indicating the total load for each temperature bin. Likewise, the bottom row on the tables indicates the total load for each hour of the day. Since the hour-of-day bins are too detailed for many applications, the same bin information has been combined into three 8-hour time-of-day periods, or two periods separating setback from no setback hours.

\section{BUILDING LOADS BINNED BY TEMPERATURE AND TIME-OF-DAY PERIODS}

These tables show the heating and cooling loads in $\mathrm{kBtu}$ for each building binned by 5 degree temperatures and by three eight-hour time-of-day periods (12 a.m. - 8 a.m., 8 a.m. - 4 p.m., and 4 p.m. - 12 a.m.), or by two periods separating setback from no setback hours of operation. Setback is assumed from 11 p.m. until $7 \mathrm{a} . \mathrm{m}$. The midpoints of the temperature bins are identified on the left of the tables. For example, the temperature bin $62.5 \mathrm{~F}$ includes loads when outdoor temperatures are between 60 and $65 \mathrm{~F}$. The time-of-day bins are identified across the top of the tables - the first three, for the eight-hour time periods; the next two, for no setback and setback hours; and the last, for the total load for all hours. The bottom row on each table gives the total load for each time-of-day period. 


\section{BUILDING LOADS BINNED BY TEMPERATURE AND HUMIDITY RATIO}

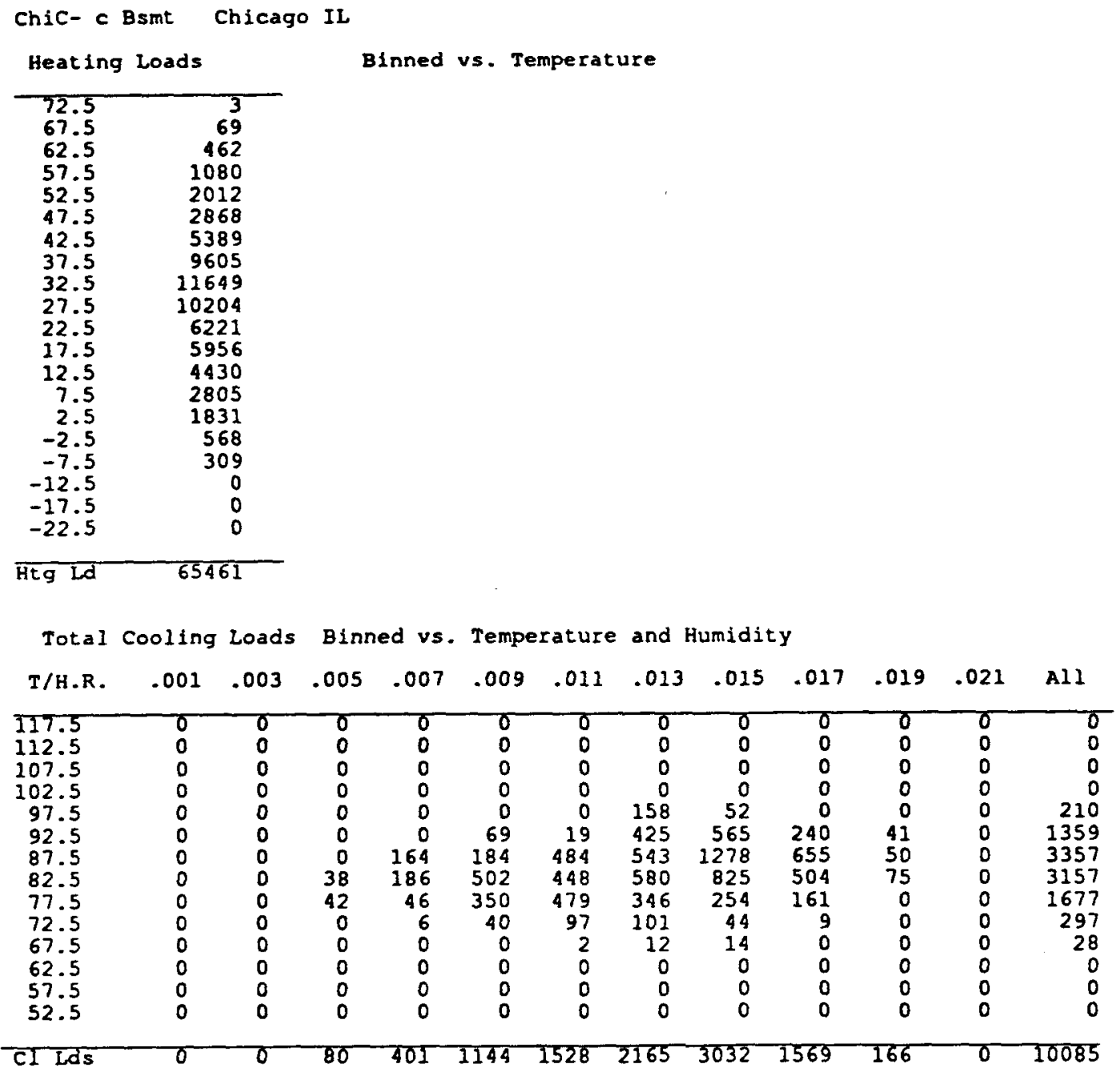

\footnotetext{
Latent cooling Loads Binned vs. Temperature and Humidity
}

$\begin{array}{llllllllllllll}\text { T/H.R. } & .001 & .003 & .005 & .007 & .009 & .011 & .013 & .015 & .017 & .019 & .021 & \mathrm{Al1}\end{array}$

\begin{tabular}{rrrrrrrrrrrrrr}
\hline 117.5 & 0 & 0 & 0 & 0 & 0 & 0 & 0 & 0 & 0 & 0 & 0 & 0 \\
112.5 & 0 & 0 & 0 & 0 & 0 & 0 & 0 & 0 & 0 & 0 & 0 & 0 \\
107.5 & 0 & 0 & 0 & 0 & 0 & 0 & 0 & 0 & 0 & 0 & 0 & 0 \\
102.5 & 0 & 0 & 0 & 0 & 0 & 0 & 0 & 0 & 0 & 0 & 0 & 0 \\
97.5 & 0 & 0 & 0 & 0 & 0 & 0 & 25 & 10 & 0 & 0 & 0 & 35 \\
92.5 & 0 & 0 & 0 & 0 & 5 & 2 & 79 & 131 & 72 & 14 & 0 & 303 \\
87.5 & 0 & 0 & 0 & 5 & 18 & 71 & 106 & 326 & 201 & 20 & 0 & 746 \\
82.5 & 0 & 0 & 0 & 5 & 49 & 74 & 124 & 230 & 175 & 31 & 0 & 688 \\
77.5 & 0 & 0 & 0 & 1 & 41 & 80 & 78 & 71 & 50 & 0 & 0 & 322 \\
72.5 & 0 & 0 & 0 & 0 & 6 & 16 & 24 & 13 & 3 & 0 & 0 & 62 \\
67.5 & 0 & 0 & 0 & 0 & 0 & 0 & 4 & 5 & 0 & 0 & 0 & 8 \\
62.5 & 0 & 0 & 0 & 0 & 0 & 0 & 0 & 0 & 0 & 0 & 0 & 0 \\
57.5 & 0 & 0 & 0 & 0 & 0 & 0 & 0 & 0 & 0 & 0 & 0 & 0 \\
52.5 & 0 & 0 & 0 & 0 & 0 & 0 & 0 & 0 & 0 & 0 & 0 & 0 \\
\hline C1 Lds & 0 & 0 & 0 & 20 & 118 & 244 & 440 & 784 & 501 & 65 & 0 & 2163
\end{tabular}




\section{BUILDING LOADS BINNED BY TEMPERATURE AND HOUR OF DAY}

Chic- c Bsmt Chlcago IL

Heat Ing Loads Binned vs. Hour and Temperature

\begin{tabular}{|c|c|c|c|c|c|c|c|c|c|c|c|c|c|c|c|c|c|c|c|c|c|c|c|c|c|}
\hline \multirow[b]{2}{*}{$\mathrm{T} /$ Hour } & \multicolumn{4}{|c|}{ Heat Ing Loads } & \multicolumn{7}{|c|}{ BInned vs. Hour and Temperature } & \multirow[b]{2}{*}{12} & \multirow[b]{2}{*}{13} & \multirow[b]{2}{*}{14} & \multirow[b]{2}{*}{15} & \multirow[b]{2}{*}{16} & \multirow[b]{2}{*}{17} & \multirow[b]{2}{*}{18} & \multirow[b]{2}{*}{19} & \multirow[b]{2}{*}{20} & \multirow[b]{2}{*}{21} & \multirow[b]{2}{*}{22} & \multirow[b]{2}{*}{23} & \multirow[b]{2}{*}{24} & \\
\hline & 1 & 2 & 3 & 4 & 5 & 6 & 7 & 8 & 9 & 10 & 11 & & & & & & & & & & & & & & \\
\hline $\begin{array}{r}72.5 \\
67.5 \\
62.5 \\
57.5 \\
52.5 \\
47.5 \\
42.5 \\
37.5 \\
32.5 \\
27.5 \\
22.5 \\
17.5 \\
12.5 \\
7.5 \\
2.5 \\
-2.5 \\
-7.5\end{array}$ & $\begin{array}{r}0 \\
0 \\
0 \\
0 \\
0 \\
2 \\
26 \\
171 \\
189 \\
341 \\
163 \\
212 \\
116 \\
127 \\
47 \\
61 \\
0 \\
0\end{array}$ & $\begin{array}{r}0 \\
0 \\
0 \\
0 \\
0 \\
12 \\
82 \\
290 \\
276 \\
422 \\
255 \\
236 \\
160 \\
146 \\
53 \\
66 \\
0 \\
0 \\
0 \\
0\end{array}$ & $\begin{array}{r}0 \\
0 \\
0 \\
2 \\
4 \\
37 \\
146 \\
335 \\
372 \\
487 \\
242 \\
261 \\
223 \\
125 \\
118 \\
32 \\
35 \\
0 \\
0 \\
0\end{array}$ & $\begin{array}{r}0 \\
0 \\
2 \\
0 \\
15 \\
69 \\
181 \\
355 \\
417 \\
535 \\
289 \\
242 \\
260 \\
129 \\
149 \\
0 \\
71 \\
0 \\
0 \\
0\end{array}$ & $\begin{array}{r}0 \\
0 \\
2 \\
0 \\
20 \\
101 \\
210 \\
396 \\
394 \\
525 \\
335 \\
198 \\
364 \\
132 \\
154 \\
0 \\
72 \\
0 \\
0\end{array}$ & $\begin{array}{r}3 \\
27 \\
144 \\
227 \\
333 \\
356 \\
368 \\
433 \\
465 \\
452 \\
405 \\
278 \\
256 \\
221 \\
96 \\
65 \\
36 \\
0 \\
0 \\
0\end{array}$ & $\begin{array}{r}0 \\
26 \\
150 \\
188 \\
420 \\
346 \\
597 \\
919 \\
862 \\
987 \\
738 \\
411 \\
517 \\
274 \\
190 \\
95 \\
47 \\
0\end{array}$ & $\begin{array}{r}0 \\
10 \\
53 \\
170 \\
240 \\
306 \\
485 \\
588 \\
772 \\
716 \\
426 \\
387 \\
472 \\
118 \\
295 \\
0 \\
47 \\
0 \\
0 \\
0\end{array}$ & $\begin{array}{r}0 \\
2 \\
41 \\
86 \\
144 \\
304 \\
223 \\
549 \\
650 \\
615 \\
324 \\
297 \\
256 \\
207 \\
140 \\
46 \\
0 \\
0 \\
0 \\
0\end{array}$ & $\begin{array}{r}0 \\
0 \\
13 \\
53 \\
100 \\
210 \\
228 \\
492 \\
554 \\
464 \\
227 \\
260 \\
196 \\
205 \\
0 \\
34 \\
0 \\
0 \\
0 \\
0\end{array}$ & $\begin{array}{r}0 \\
2 \\
3 \\
55 \\
73 \\
114 \\
215 \\
414 \\
539 \\
287 \\
300 \\
221 \\
95 \\
109 \\
29 \\
0 \\
0 \\
0 \\
0 \\
0\end{array}$ & $\begin{array}{r}0 \\
0 \\
5 \\
33 \\
87 \\
110 \\
192 \\
406 \\
513 \\
222 \\
269 \\
135 \\
125 \\
53 \\
25 \\
0 \\
0 \\
0 \\
0 \\
0\end{array}$ & $\begin{array}{r}0 \\
6 \\
29 \\
93 \\
50 \\
190 \\
402 \\
454 \\
261 \\
187 \\
226 \\
65 \\
24 \\
0 \\
0 \\
0 \\
0 \\
0 \\
0\end{array}$ & $\begin{array}{r}0 \\
0 \\
6 \\
22 \\
64 \\
41 \\
201 \\
353 \\
429 \\
246 \\
157 \\
227 \\
19 \\
45 \\
0 \\
0 \\
0 \\
0 \\
0 \\
0\end{array}$ & $\begin{array}{r}0 \\
2 \\
33 \\
52 \\
62 \\
196 \\
284 \\
464 \\
205 \\
216 \\
141 \\
64 \\
22 \\
0 \\
0 \\
0 \\
0 \\
0 \\
0\end{array}$ & $\begin{array}{r}0 \\
0 \\
6 \\
28 \\
45 \\
51 \\
215 \\
290 \\
482 \\
249 \\
135 \\
190 \\
75 \\
25 \\
22 \\
0 \\
0 \\
0 \\
0 \\
0\end{array}$ & $\begin{array}{r}0 \\
0 \\
6 \\
24 \\
39 \\
72 \\
223 \\
285 \\
556 \\
250 \\
159 \\
214 \\
101 \\
65 \\
25 \\
0 \\
0 \\
0 \\
0 \\
0\end{array}$ & $\begin{array}{r}0 \\
0 \\
5 \\
18 \\
49 \\
84 \\
227 \\
359 \\
527 \\
388 \\
167 \\
226 \\
161 \\
78 \\
30 \\
0 \\
0 \\
0 \\
0 \\
0\end{array}$ & $\begin{array}{r}0 \\
0 \\
6 \\
21 \\
40 \\
120 \\
236 \\
361 \\
525 \\
409 \\
232 \\
198 \\
182 \\
115 \\
60 \\
0 \\
0 \\
0 \\
0 \\
0\end{array}$ & $\begin{array}{r}0 \\
0 \\
1 \\
26 \\
41 \\
104 \\
223 \\
433 \\
531 \\
410 \\
240 \\
307 \\
159 \\
106 \\
100 \\
0 \\
0 \\
0 \\
0 \\
0\end{array}$ & $\begin{array}{r}438 \\
229 \\
291 \\
200 \\
140 \\
73 \\
0 \\
0 \\
0 \\
0 \\
0\end{array}$ & $\begin{array}{r}0 \\
1 \\
3 \\
29 \\
64 \\
130 \\
264 \\
489 \\
535 \\
532 \\
178 \\
325 \\
202 \\
57 \\
134 \\
37 \\
0 \\
0\end{array}$ & $\begin{array}{r}0 \\
0 \\
1 \\
10 \\
46 \\
73 \\
227 \\
512 \\
513 \\
622 \\
239 \\
339 \\
109 \\
191\end{array}$ & $\begin{array}{r}0 \\
0 \\
0 \\
0 \\
0 \\
0 \\
2 \\
12 \\
39 \\
141 \\
108 \\
132 \\
55\end{array}$ & $\begin{array}{r}69 \\
462 \\
1080 \\
2012 \\
2868 \\
5389 \\
9605 \\
11649 \\
10204 \\
6221 \\
5956 \\
4430 \\
2805 \\
1831 \\
568 \\
309 \\
0\end{array}$ \\
\hline & & & & 12 & & 37 & & 85 & & 3036 & & 2176 & & 11 & & 1813 & & 2320 & & 2681 & & 2983 & 3026 & 57 & \\
\hline
\end{tabular}




\section{BUILDING LOADS BINNED BY TEMPERATURE AND HOUR OF DAY (CONT.)}

Chic- c Bsmt Chicago IL

Total Cooling Loads Binned vs. Hour and Temperature

\begin{tabular}{|c|c|c|c|c|c|c|c|c|c|c|c|c|c|c|c|c|c|c|c|c|c|c|c|c|c|}
\hline T/Hour & 1 & 2 & 3 & 4 & 5 & 6 & 7 & 8 & 9 & 10 & 11 & 12 & 13 & 14 & 15 & 16 & 17 & 18 & 19 & 20 & 21 & 22 & 23 & 24 & \\
\hline $\begin{array}{r}112.5 \\
107.5 \\
102.5 \\
97.5 \\
92.5 \\
87.5 \\
82.5 \\
77.5 \\
72.5 \\
67.5 \\
62.5 \\
57.5 \\
52.5\end{array}$ & $\begin{array}{l}0 \\
0 \\
0 \\
0 \\
0 \\
0 \\
3 \\
3 \\
0 \\
0 \\
0 \\
0\end{array}$ & $\begin{array}{l}0 \\
0 \\
0 \\
0 \\
0 \\
0 \\
0 \\
0 \\
0 \\
0 \\
0 \\
0\end{array}$ & $\begin{array}{l}0 \\
0 \\
0 \\
0 \\
0 \\
0 \\
0 \\
0 \\
0 \\
0 \\
0\end{array}$ & $\begin{array}{l}0 \\
0 \\
0 \\
0 \\
0 \\
0 \\
0 \\
0 \\
0 \\
0 \\
0 \\
0\end{array}$ & $\begin{array}{l}0 \\
0 \\
0 \\
0 \\
0 \\
0 \\
0 \\
0 \\
0 \\
0 \\
0\end{array}$ & $\begin{array}{l}0 \\
0 \\
0 \\
0 \\
0 \\
0 \\
0 \\
0 \\
0 \\
0 \\
0\end{array}$ & $\begin{array}{l}0 \\
0 \\
0 \\
0 \\
0 \\
3 \\
2 \\
0 \\
0\end{array}$ & $\begin{array}{r}0 \\
0 \\
0 \\
0 \\
0 \\
0 \\
6 \\
39 \\
10 \\
0 \\
0 \\
0 \\
0 \\
0\end{array}$ & $\begin{array}{r}0 \\
0 \\
0 \\
0 \\
0 \\
11 \\
34 \\
112 \\
2 \\
0 \\
0 \\
0 \\
0 \\
0\end{array}$ & $\begin{array}{r}0 \\
0 \\
0 \\
0 \\
0 \\
17 \\
163 \\
145 \\
26 \\
0 \\
0 \\
0 \\
0 \\
0\end{array}$ & $\begin{array}{r}0 \\
0 \\
0 \\
0 \\
16 \\
36 \\
284 \\
136 \\
33 \\
0 \\
0 \\
0 \\
0 \\
0\end{array}$ & $\begin{array}{r}0 \\
0 \\
0 \\
0 \\
18 \\
110 \\
307 \\
171 \\
31 \\
0 \\
0 \\
0 \\
0 \\
0\end{array}$ & $\begin{array}{r}0 \\
0 \\
0 \\
0 \\
32 \\
208 \\
339 \\
174 \\
61 \\
3 \\
0 \\
0 \\
0 \\
0\end{array}$ & $\begin{array}{r}0 \\
0 \\
0 \\
0 \\
38 \\
279 \\
362 \\
275 \\
92 \\
3 \\
0 \\
0 \\
0 \\
0\end{array}$ & $\begin{array}{r}0 \\
0 \\
0 \\
0 \\
42 \\
273 \\
421 \\
324 \\
142 \\
6 \\
0 \\
0 \\
0 \\
0\end{array}$ & $\begin{array}{r}0 \\
0 \\
0 \\
0 \\
21 \\
238 \\
455 \\
365 \\
192 \\
29 \\
0 \\
0 \\
0 \\
0\end{array}$ & $\begin{array}{r}0 \\
0 \\
0 \\
0 \\
43 \\
149 \\
380 \\
393 \\
230 \\
46 \\
9 \\
0 \\
0 \\
0\end{array}$ & $\begin{array}{r}0 \\
0 \\
0 \\
0 \\
0 \\
38 \\
375 \\
320 \\
225 \\
45 \\
13 \\
0 \\
0 \\
0\end{array}$ & $\begin{array}{r}0 \\
0 \\
0 \\
0 \\
182 \\
261 \\
188 \\
42 \\
5 \\
0 \\
0 \\
0\end{array}$ & $\begin{array}{r}0 \\
0 \\
0 \\
0 \\
0 \\
0 \\
39 \\
209 \\
150 \\
53 \\
2 \\
0 \\
0 \\
0\end{array}$ & $\begin{array}{r}0 \\
0 \\
0 \\
0 \\
0 \\
0 \\
10 \\
119 \\
117 \\
48 \\
0 \\
0 \\
0 \\
0\end{array}$ & $\begin{array}{r}0 \\
0 \\
0 \\
0 \\
66 \\
93 \\
17 \\
0 \\
0 \\
0 \\
0\end{array}$ & $\begin{array}{l}0 \\
0 \\
0 \\
0 \\
0 \\
0\end{array}$ & $\begin{array}{r}0 \\
0 \\
0 \\
0 \\
0 \\
0 \\
0 \\
10 \\
14 \\
0 \\
0 \\
0 \\
0 \\
0\end{array}$ & $\begin{array}{r}210 \\
1359 \\
3357 \\
3157 \\
1677 \\
297 \\
28\end{array}$ \\
\hline & & 0 & 0 & 0 & 0 & 0 & 5 & 55 & 159 & 351 & 506 & 636 & 817 & 1049 & 207 & 1300 & 1250 & 1017 & 678 & 452 & 294 & 175 & 105 & 24 & \\
\hline
\end{tabular}

Ch1C- c Bsmt Chicago IL

Latent Cooling Loads Binned vs. Hour and Temperature

\begin{tabular}{|c|c|c|c|c|c|c|c|c|c|c|c|c|c|c|c|c|c|c|c|c|c|c|c|c|c|}
\hline T/Hour & 1 & 2 & 3 & 4 & 5 & 6 & 7 & 8 & 9 & 10 & 11 & 12 & 13 & 14 & 15 & 16 & 17 & 18 & 19 & 20 & 21 & $22^{\circ}$ & 23 & 24 & \\
\hline $\begin{array}{r}117.5 \\
112.5 \\
107.5 \\
102.5 \\
97.5 \\
92.5 \\
87.5 \\
82.5 \\
77.5 \\
72.5 \\
67.5 \\
62.5 \\
57.5 \\
52.5\end{array}$ & $\begin{array}{l}0 \\
0 \\
0 \\
0 \\
0 \\
0 \\
0 \\
1 \\
1 \\
0 \\
0 \\
0 \\
0 \\
0\end{array}$ & $\begin{array}{l}0 \\
0 \\
0 \\
0 \\
0 \\
0 \\
0 \\
0 \\
0 \\
0 \\
0 \\
0 \\
0 \\
0\end{array}$ & $\begin{array}{l}0 \\
0 \\
0 \\
0 \\
0 \\
0 \\
0 \\
0 \\
0 \\
0 \\
0 \\
0 \\
0 \\
0\end{array}$ & $\begin{array}{l}0 \\
0 \\
0 \\
0 \\
0 \\
0 \\
0 \\
0 \\
0 \\
0 \\
0 \\
0 \\
0 \\
0\end{array}$ & $\begin{array}{l}0 \\
0 \\
0 \\
0 \\
0 \\
0 \\
0 \\
0 \\
0 \\
0 \\
0 \\
0 \\
0 \\
0\end{array}$ & $\begin{array}{l}0 \\
0 \\
0 \\
0 \\
0 \\
0 \\
0 \\
0 \\
0 \\
0 \\
0 \\
0 \\
0 \\
0\end{array}$ & $\begin{array}{l}0 \\
0 \\
0 \\
0 \\
0 \\
0 \\
0 \\
1 \\
1 \\
0 \\
0 \\
0 \\
0 \\
0\end{array}$ & $\begin{array}{r}0 \\
0 \\
0 \\
0 \\
0 \\
0 \\
2 \\
11 \\
3 \\
0 \\
0 \\
0 \\
0 \\
0\end{array}$ & $\begin{array}{r}0 \\
0 \\
0 \\
0 \\
0 \\
2 \\
8 \\
33 \\
0 \\
0 \\
0 \\
0 \\
0 \\
0\end{array}$ & $\begin{array}{r}0 \\
0 \\
0 \\
0 \\
0 \\
4 \\
43 \\
37 \\
6 \\
0 \\
0 \\
0 \\
0 \\
0\end{array}$ & $\begin{array}{r}0 \\
0 \\
0 \\
0 \\
3 \\
9 \\
68 \\
32 \\
8 \\
0 \\
0 \\
0 \\
0 \\
0\end{array}$ & $\begin{array}{r}0 \\
0 \\
0 \\
0 \\
3 \\
32 \\
70 \\
38 \\
6 \\
0 \\
0 \\
0 \\
0 \\
0\end{array}$ & $\begin{array}{r}0 \\
0 \\
0 \\
0 \\
6 \\
46 \\
75 \\
35 \\
12 \\
1 \\
0 \\
0 \\
0 \\
0\end{array}$ & $\begin{array}{c}0 \\
0 \\
0 \\
0 \\
7 \\
61 \\
77 \\
51 \\
15 \\
1 \\
0 \\
0 \\
0 \\
0\end{array}$ & $\begin{array}{r}0 \\
0 \\
0 \\
0 \\
7 \\
59 \\
88 \\
52 \\
26 \\
0 \\
0 \\
0 \\
0 \\
0\end{array}$ & $\begin{array}{r}0 \\
0 \\
0 \\
0 \\
3 \\
50 \\
93 \\
58 \\
27 \\
5 \\
0 \\
0 \\
0 \\
0\end{array}$ & $\begin{array}{r}0 \\
0 \\
0 \\
0 \\
6 \\
33 \\
78 \\
68 \\
39 \\
11 \\
2 \\
0 \\
0 \\
0\end{array}$ & $\begin{array}{r}0 \\
0 \\
0 \\
0 \\
0 \\
7 \\
80 \\
69 \\
35 \\
9 \\
4 \\
0 \\
0 \\
0\end{array}$ & $\begin{array}{r}0 \\
0 \\
0 \\
0 \\
0 \\
0 \\
52 \\
62 \\
40 \\
10 \\
1 \\
0 \\
0 \\
0\end{array}$ & $\begin{array}{r}0 \\
0 \\
0 \\
0 \\
0 \\
0 \\
10 \\
61 \\
31 \\
11 \\
1 \\
0 \\
0 \\
0\end{array}$ & $\begin{array}{r}0 \\
0 \\
0 \\
0 \\
0 \\
0 \\
3 \\
41 \\
27 \\
10 \\
0 \\
0 \\
0 \\
0\end{array}$ & $\begin{array}{r}0 \\
0 \\
0 \\
0 \\
0 \\
0 \\
0 \\
23 \\
24 \\
3 \\
0 \\
0 \\
0 \\
0\end{array}$ & $\begin{array}{r}0 \\
0 \\
0 \\
0 \\
0 \\
0 \\
0 \\
12 \\
17 \\
1 \\
0 \\
0 \\
0 \\
0\end{array}$ & $\begin{array}{l}0 \\
0 \\
0 \\
0 \\
0 \\
0 \\
0 \\
3 \\
4 \\
0 \\
0 \\
0 \\
0 \\
0\end{array}$ & $\begin{array}{r}0 \\
0 \\
0 \\
0 \\
35 \\
303 \\
746 \\
688 \\
322 \\
62 \\
8 \\
0 \\
0 \\
0\end{array}$ \\
\hline COOI & 2 & 0 & 0 & 0 & 0 & 0 & 1 & 16 & 43 & 89 & 119 & 148 & 175 & 212 & 232 & 237 & 238 & 204 & 165 & 113 & 81 & 51 & 30 & 7 & 163 \\
\hline
\end{tabular}




\section{BUILDING LOADS BINNED BY TEMPERATURE AND TIME OF DAY PERIODS}

Chic- C Bsmt Chicago IL

Heating Loads Binned vs. Time of Day and Temperature

$12 a m-8 a m$ 8am-4pm 4pm-12an $\begin{gathered}\text { No setback } \\ \text { Hours }\end{gathered} \begin{gathered}\begin{array}{c}\text { Setback Hours } \\ \text { Hours }\end{array} \text { All } \\ \text { Hours }\end{gathered}$

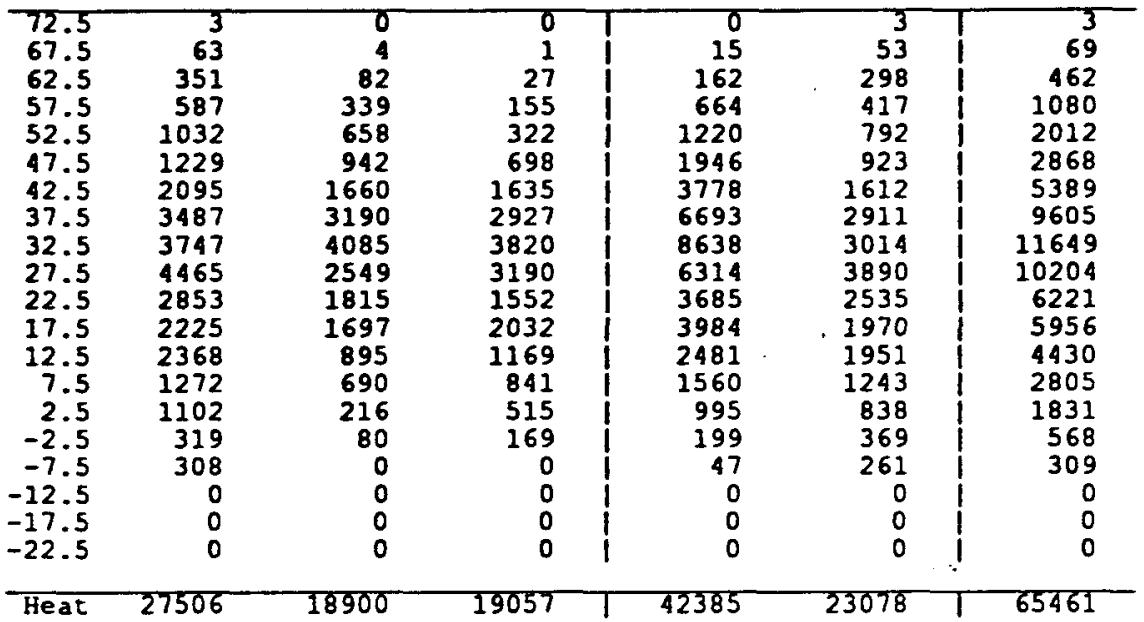

Total Cooling Loads Binned vs. Time of Day and Temperature

$12 \mathrm{am}-8 \mathrm{am}$ 8am-4pm 4pm-12am $\left|\begin{array}{c}\text { No setback } \\ \text { Hours }\end{array} \begin{array}{c}\text { Setback } \\ \text { Hours }\end{array}\right| \begin{gathered}\text { All } \\ \text { Hours }\end{gathered}$

\begin{tabular}{|c|c|c|c|c|c|c|}
\hline $\begin{array}{l}117.5 \\
112.5 \\
107.5 \\
102.5 \\
97.5 \\
92.5 \\
87.5 \\
82.5 \\
77.5 \\
72.5 \\
67.5 \\
62.5 \\
57.5 \\
52.5\end{array}$ & $\begin{array}{r}0 \\
0 \\
0 \\
0 \\
0 \\
0 \\
6 \\
45 \\
15 \\
0 \\
0 \\
0 \\
0 \\
0\end{array}$ & $\begin{array}{r}0 \\
0 \\
0 \\
0 \\
167 \\
1172 \\
2365 \\
1702 \\
579 \\
41 \\
0 \\
0 \\
0 \\
0\end{array}$ & $\begin{array}{r}0 \\
0 \\
0 \\
0 \\
43 \\
187 \\
986 \\
1412 \\
1084 \\
256 \\
29 \\
0 \\
0 \\
0\end{array}$ & $\begin{array}{r}0 \\
0 \\
0 \\
0 \\
210 \\
1359 \\
3357 \\
3143 \\
1659 \ldots \\
297 \\
29 \\
0 \\
0 \\
0\end{array}$ & $\begin{array}{r}0 \\
0 \\
0 \\
0 \\
0 \\
0 \\
0 \\
16 \\
19 \\
0 \\
0 \\
0 \\
0 \\
0\end{array}$ & $\begin{array}{r}0 \\
0 \\
0 \\
0 \\
210 \\
1359 \\
3357 \\
3157 \\
1677 \\
297 \\
28 \\
0 \\
0 \\
0\end{array}$ \\
\hline$c$ & 65 & 6025 & 3995 & 10051 & 34 & 10085 \\
\hline
\end{tabular}

Latent Cooling Loads Binned vs. Time of Day and Temperature

\begin{tabular}{|c|c|c|c|c|c|c|}
\hline & $12 \mathrm{am}-8 \mathrm{am}$ & $8 a m-4 p m$ & $4 p m-12 a m$ & $\begin{array}{c}\text { No setback } \\
\text { Hours }\end{array}$ & $\begin{array}{c}\text { Setback } \\
\text { Hours }\end{array}$ & $\begin{array}{c}\text { All } \\
\text { Hours }\end{array}$ \\
\hline $\begin{array}{r}117.5 \\
112.5 \\
107.5 \\
102.5 \\
97.5 \\
92.5 \\
87.5 \\
82.5 \\
77.5 \\
72.5 \\
67.5 \\
62.5 \\
57.5 \\
52.5\end{array}$ & $\begin{array}{r}0 \\
0 \\
0 \\
0 \\
0 \\
0 \\
2 \\
13 \\
5 \\
0 \\
0 \\
0 \\
0 \\
0\end{array}$ & $\begin{array}{r}0 \\
0 \\
0 \\
0 \\
29 \\
263 \\
522 \\
336 \\
100 \\
7 \\
0 \\
0 \\
0 \\
0\end{array}$ & $\begin{array}{r}0 \\
0 \\
0 \\
0 \\
6 \\
40 \\
223 \\
339 \\
217 \\
55 \\
8 \\
0 \\
0 \\
0\end{array}$ & $\begin{array}{r}0 \\
0 \\
0 \\
0 \\
35 \\
303 \\
747 \\
683 \\
316 \\
62 \\
8 \\
0 \\
0 \\
0\end{array}$ & $\begin{array}{l}0 \\
0 \\
0 \\
0 \\
0 \\
0 \\
0 \\
5 \\
6 \\
0 \\
0 \\
0 \\
0 \\
0\end{array}$ & $\begin{array}{r}0 \\
0 \\
0 \\
0 \\
35 \\
303 \\
746 \\
688 \\
322 \\
62 \\
8 \\
0 \\
0 \\
0\end{array}$ \\
\hline Cool & 19 & 1255 & 889 & 2153 & 10 & 2163 \\
\hline
\end{tabular}




\section{APPENDIX I: BINNED CLIMATE DATA}

The bins are identified on the left and across the top of each table, with the identifier denoting the midpoint of each bin. For example, the temperature bin $62.5 \mathrm{~F}$ indicates the number of hours when outside temperatures are between 60 and $65 \mathrm{~F}$; likewise, the humidity bin 0.003 indicates the number of hours when humidity ratios are between 0.002 and 0.004 . 


\section{BINNED CLIMATE DATA}

Ch1C- c Bsmt Chicago IL

Amblent Hours Blnned vs. Hour and Temperature

$\begin{array}{lllllllllllllllllllllllll}\text { T/Hour } & 1 & 2 & 3 & 4 & 5 & 6 & 7 & 8 & 9 & 10 & 11 & 12 & 13 & 14 & 15 & 16 & 17 & 18 & 19 & 20 & 21 & 22 & 23 & 24\end{array}$

\begin{tabular}{|c|c|c|c|c|c|c|c|c|c|c|c|c|c|c|c|c|c|c|c|c|c|c|c|c|c|c|}
\hline $\begin{array}{r}12 \\
7 \\
2 \\
-2 \\
-7\end{array}$ & $\begin{array}{r}20 \\
26 \\
39 \\
27 \\
32 \\
12 \\
13 \\
7 \\
6 \\
2 \\
2 \\
0 \\
0 \\
0 \\
0\end{array}$ & $\begin{array}{r}0 \\
0 \\
0 \\
0 \\
0 \\
0 \\
0 \\
0 \\
0 \\
16 \\
25 \\
41 \\
33 \\
36 \\
22 \\
21 \\
28 \\
39 \\
27 \\
32 \\
15 \\
12 \\
8 \\
6 \\
2 \\
2 \\
0 \\
0 \\
0 \\
0 \\
0\end{array}$ & $\begin{array}{r}0 \\
0 \\
0 \\
0 \\
0 \\
0 \\
0 \\
0 \\
0 \\
99 \\
32 \\
37 \\
34 \\
40 \\
18 \\
22 \\
29 \\
35 \\
31 \\
32 \\
13 \\
12 \\
10 \\
5 \\
4 \\
1 \\
1 \\
0 \\
0 \\
0\end{array}$ & $\begin{array}{r}0 \\
0 \\
0 \\
0 \\
0 \\
0 \\
0 \\
0 \\
0 \\
6 \\
31 \\
38 \\
31 \\
40 \\
21 \\
24 \\
28 \\
34 \\
31 \\
33 \\
14 \\
11 \\
11 \\
5 \\
5 \\
0 \\
2 \\
0 \\
0 \\
0\end{array}$ & $\begin{array}{r}0 \\
0 \\
0 \\
0 \\
0 \\
0 \\
0 \\
0 \\
0 \\
6 \\
24 \\
44 \\
35 \\
36 \\
20 \\
25 \\
28 \\
35 \\
29 \\
31 \\
16 \\
9 \\
15 \\
5 \\
5 \\
0 \\
2 \\
0 \\
0 \\
0\end{array}$ & $\begin{array}{r}0 \\
0 \\
0 \\
0 \\
0 \\
0 \\
0 \\
0 \\
0 \\
9 \\
30 \\
40 \\
35 \\
26 \\
30 \\
24 \\
26 \\
32 \\
31 \\
26 \\
20 \\
12 \\
10 \\
8 \\
3 \\
2 \\
1 \\
0\end{array}$ & $\begin{array}{r}0 \\
0 \\
0 \\
0 \\
0 \\
0 \\
0 \\
0 \\
1 \\
20 \\
35 \\
38 \\
32 \\
22 \\
31 \\
19 \\
25 \\
33 \\
27 \\
28 \\
19 \\
10 \\
12 \\
6 \\
4 \\
2 \\
1 \\
0 \\
0 \\
0\end{array}$ & $\begin{array}{l}0 \\
0 \\
0 \\
0 \\
0 \\
0 \\
0 \\
1 \\
9 \\
35 \\
35 \\
29 \\
25 \\
28 \\
24 \\
23 \\
27 \\
26 \\
30 \\
25 \\
13 \\
11 \\
13\end{array}$ & $\begin{array}{r}0 \\
0 \\
0 \\
0 \\
0 \\
0 \\
1 \\
4 \\
23 \\
33 \\
31 \\
30 \\
29 \\
25 \\
21 \\
29 \\
14 \\
30 \\
30 \\
25 \\
11 \\
10 \\
8 \\
6 \\
4 \\
1 \\
0 \\
0\end{array}$ & $\begin{array}{r}0 \\
0 \\
0 \\
0 \\
0 \\
0 \\
1 \\
15 \\
29 \\
34 \\
26 \\
27 \\
29 \\
19 \\
24 \\
26 \\
19 \\
32 \\
28 \\
22 \\
9 \\
10 \\
7 \\
7 \\
0 \\
1 \\
0 \\
0 \\
0 \\
0\end{array}$ & $\begin{array}{r}0 \\
0 \\
0 \\
0 \\
0 \\
1 \\
3 \\
25 \\
27 \\
30 \\
26 \\
29 \\
24 \\
23 \\
23 \\
19 \\
23 \\
32 \\
32 \\
15 \\
14 \\
10 \\
4 \\
4 \\
1 \\
0 \\
0 \\
0\end{array}$ & $\begin{array}{r}0 \\
0 \\
0 \\
0 \\
1 \\
7 \\
25 \\
33 \\
24 \\
29 \\
30 \\
20 \\
24 \\
25 \\
18 \\
23 \\
32 \\
33 \\
12 \\
14\end{array}$ & $\begin{array}{r}0 \\
0 \\
2 \\
12 \\
28 \\
27 \\
32 \\
23 \\
26 \\
25 \\
23 \\
23 \\
16 \\
25 \\
34 \\
29 \\
15 \\
10 \\
11\end{array}$ & $\begin{array}{r}14 \\
31 \\
32 \\
27 \\
17 \\
8 \\
12 \\
1 \\
2 \\
0 \\
0 \\
0 \\
0\end{array}$ & $\begin{array}{r}2 \\
13 \\
26 \\
32 \\
29 \\
24 \\
23 \\
28 \\
23 \\
18 \\
19 \\
29 \\
29 \\
31 \\
15 \\
12\end{array}$ & $\begin{array}{r}31 \\
30 \\
32 \\
16 \\
9 \\
9 \\
4 \\
1 \\
1 \\
0\end{array}$ & $\begin{array}{r}7 \\
22 \\
30 \\
28 \\
28 \\
20 \\
27 \\
26 \\
20 \\
17 \\
30 \\
30 \\
35 \\
15 \\
9 \\
11\end{array}$ & $\begin{array}{r}28 \\
31 \\
34 \\
21 \\
8 \\
10\end{array}$ & $\begin{array}{r}0 \\
0 \\
12 \\
25 \\
28 \\
27 \\
37 \\
21 \\
27 \\
19 \\
25 \\
25 \\
31 \\
34 \\
21 \\
11\end{array}$ & $\begin{array}{r}0 \\
0 \\
0 \\
0 \\
0 \\
0 \\
0 \\
3 \\
23 \\
27 \\
34\end{array}$ & $\begin{array}{l}0 \\
0 \\
0\end{array}$ & 28 & & c & $\begin{array}{l}0 \\
0 \\
0\end{array}$ & $=$ \\
\hline
\end{tabular}




\section{BINNED CLIMATE DATA (CONT.)}

\begin{tabular}{|c|c|c|c|c|c|c|c|c|c|c|c|c|}
\hline \multirow[b]{2}{*}{ T/H.R. } & \multirow[b]{2}{*}{.001} & \multirow[b]{2}{*}{.003} & \multirow[b]{2}{*}{.005} & \multicolumn{3}{|c|}{ Ambient Hours } & \multicolumn{2}{|c|}{ Binned vs } & \multicolumn{3}{|c|}{ - Humidity and } & \multirow{2}{*}{$\begin{array}{c}\text { Temper } \\
\text { All }\end{array}$} \\
\hline & & & & .007 & .009 & .011 & .013 & .015 & .017 & .019 & .021 & \\
\hline $\begin{array}{r}122.5 \\
117.5 \\
112.5 \\
107.5 \\
102.5 \\
97.5 \\
92.5 \\
87.5 \\
82.5 \\
77.5 \\
72.5 \\
67.5 \\
62.5 \\
57.5 \\
52.5 \\
47.5 \\
42.5 \\
37.5 \\
32.5 \\
27.5 \\
22.5 \\
17.5 \\
12.5 \\
7.5 \\
2.5 \\
-2.5 \\
-7.5 \\
-12.5 \\
-17.5 \\
-22.5\end{array}$ & $\begin{array}{r}0 \\
0 \\
0 \\
0 \\
0 \\
0 \\
0 \\
0 \\
0 \\
0 \\
0 \\
0 \\
1 \\
0 \\
2 \\
9 \\
26 \\
33 \\
136 \\
283 \\
264 \\
260 \\
168 \\
101 \\
56 \\
16 \\
8 \\
0 \\
0 \\
0\end{array}$ & $\begin{array}{r}0 \\
0 \\
0 \\
0 \\
0 \\
0 \\
0 \\
0 \\
0 \\
1 \\
13 \\
20 \\
52 \\
65 \\
105 \\
157 \\
327 \\
613 \\
603 \\
280 \\
25 \\
0 \\
0 \\
0 \\
0 \\
0 \\
0 \\
0 \\
0 \\
0\end{array}$ & $\begin{array}{r}0 \\
0 \\
0 \\
0 \\
0 \\
0 \\
0 \\
0 \\
4 \\
20 \\
48 \\
75 \\
88 \\
172 \\
210 \\
247 \\
266 \\
148 \\
4 \\
0 \\
0 \\
0 \\
0 \\
0 \\
0 \\
0 \\
0 \\
0 \\
0 \\
0\end{array}$ & $\begin{array}{r}0 \\
0 \\
0 \\
0 \\
0 \\
0 \\
0 \\
14 \\
25 \\
31 \\
85 \\
122 \\
251 \\
262 \\
206 \\
93 \\
2 \\
0 \\
0 \\
0 \\
0 \\
0 \\
0 \\
0 \\
0 \\
0 \\
0 \\
0 \\
0 \\
0\end{array}$ & $\begin{array}{r}0 \\
0 \\
0 \\
0 \\
0 \\
0 \\
4 \\
13 \\
47 \\
101 \\
143 \\
166 \\
189 \\
155 \\
11 \\
0 \\
0 \\
0 \\
0 \\
0 \\
0 \\
0 \\
0 \\
0 \\
0 \\
0 \\
0 \\
0 \\
0 \\
0\end{array}$ & $\begin{array}{r}0 \\
0 \\
0 \\
0 \\
0 \\
0 \\
1 \\
37 \\
62 \\
116 \\
119 \\
192 \\
111 \\
6 \\
0 \\
0 \\
0 \\
0 \\
0 \\
0 \\
0 \\
0 \\
0 \\
0 \\
0 \\
0 \\
0 \\
0 \\
0 \\
0\end{array}$ & $\begin{array}{r}0 \\
0 \\
0 \\
0 \\
0 \\
8 \\
23 \\
38 \\
73 \\
106 \\
169 \\
162 \\
3 \\
0 \\
0 \\
0 \\
0 \\
0 \\
0 \\
0 \\
0 \\
0 \\
0 \\
0 \\
0 \\
0 \\
0 \\
0 \\
0 \\
0\end{array}$ & $\begin{array}{r}0 \\
0 \\
0 \\
0 \\
0 \\
3 \\
30 \\
88 \\
97 \\
116 \\
110 \\
34 \\
0 \\
0 \\
0 \\
0 \\
0 \\
0 \\
0 \\
0 \\
0 \\
0 \\
0 \\
0 \\
0 \\
0 \\
0 \\
0 \\
0 \\
0\end{array}$ & $\begin{array}{c}0 \\
0 \\
0 \\
0 \\
0 \\
0 \\
12 \\
44 \\
61 \\
75 \\
20 \\
0 \\
0 \\
0 \\
0 \\
0 \\
0 \\
0 \\
0 \\
0 \\
0 \\
0 \\
0 \\
0 \\
0 \\
0 \\
0 \\
0 \\
0 \\
0\end{array}$ & $\begin{array}{r}0 \\
0 \\
0 \\
0 \\
0 \\
0 \\
2 \\
4 \\
10 \\
2 \\
0 \\
0 \\
0 \\
0 \\
0 \\
0 \\
0 \\
0 \\
0 \\
0 \\
0 \\
0 \\
0 \\
0 \\
0 \\
0 \\
0 \\
0 \\
0 \\
0\end{array}$ & $\begin{array}{l}0 \\
0 \\
0 \\
0 \\
0 \\
0 \\
0 \\
0 \\
0 \\
0 \\
0 \\
0 \\
0 \\
0 \\
0 \\
0 \\
0 \\
0 \\
0 \\
0 \\
0 \\
0 \\
0 \\
0 \\
0 \\
0 \\
0 \\
0 \\
0 \\
0\end{array}$ & $\begin{array}{r}0 \\
0 \\
0 \\
0 \\
0 \\
11 \\
72 \\
238 \\
379 \\
568 \\
707 \\
771 \\
695 \\
660 \\
534 \\
506 \\
621 \\
794 \\
743 \\
563 \\
289 \\
260 \\
168 \\
101 \\
56 \\
16 \\
8 \\
0 \\
0 \\
0 \\
0\end{array}$ \\
\hline
\end{tabular}

